Documentation of Unassociated and Culturally Unidentifiable Funerary Objects in the U. S. Army Corps of Engineers, Fort Worth District Collections Housed at the Texas Archeological Research Laboratory at the University of Texas at Austin

Timothy K. Perttula

Heritage Research Center, Stephen F. Austin State University

Robert Cast

Bobby Gonzalez

Bo Nelson

Heritage Research Center, Stephen F. Austin State University

Follow this and additional works at: https://scholarworks.sfasu.edu/ita

Part of the American Material Culture Commons, Archaeological Anthropology Commons, Environmental Studies Commons, Other American Studies Commons, Other Arts and Humanities Commons, Other History of Art, Architecture, and Archaeology Commons, and the United States History Commons

Tell us how this article helped you.

This Article is brought to you for free and open access by the Center for Regional Heritage Research at SFA ScholarWorks. It has been accepted for inclusion in Index of Texas Archaeology: Open Access Gray Literature from the Lone Star State by an authorized editor of SFA ScholarWorks. For more information, please contact cdsscholarworks@sfasu.edu. 
Documentation of Unassociated and Culturally Unidentifiable Funerary Objects in the U. S. Army Corps of Engineers, Fort Worth District Collections Housed at the Texas Archeological Research Laboratory at the University of Texas at Austin

Creative Commons License

(c) (i) (9)

This work is licensed under a Creative Commons Attribution-NonCommercial 4.0 International License 


\title{
DOCUMENTATION OF UNASSOCIATED AND CULTURALLY UNIDENTIFIABLE FUNERARY OBJECTS IN THE U.S. ARMY CORPS OF ENGINEERS, FORT WORTH DISTRICT COLLECTIONS HOUSED AT THE TEXAS ARCHEOLOGICAL RESEARCH LABORATORY AT THE UNIVERSITY OF TEXAS AT AUSTIN
}

\author{
Timothy K. Perttula, \\ Robert Cast, \\ Bobby Gonzalez, \\ and Bo Nelson
}

\author{
HISTORIC PRESERVATION PROGRAM \\ CADDO NATION OF OKLAHOMA \\ BINGER, OKLAHOMA
}

SPECIAL PUBLICATION NO. 13

FRIENDS OF NORTHEAST TEXAS ARCHAEOLOGY

PIITSBURG AND AUSTIN, TEXAS 


\section{TABLE OF CONTENTS}

$\begin{array}{ll}\text { List of Figures } & \text { iii }\end{array}$

List of Tables $\quad$ vi

Acknowledgments vii

Introduction and Purpose of the Study 1

NAGPRA Collections $\quad 1$

Study of the Ceramic Vessels $\quad 1$

Snipes Site (41CS8) 4

Knight's Bluff Site (41CS14) 5

Sherwin Site (41CS26) 6

Ben McKinney Site (41MR12) 8

Pleasure Point Site (41MR63) 15

$\begin{array}{lr}\text { Jonas Short Site (41SA101) } & 17\end{array}$

Walter Bell Site (41SB50) 22

NAGPRA Findings and Recommendations 23

$\begin{array}{ll}\text { References Cited } & 27\end{array}$

Appendix 1, Vessel Recordation Forms, 41CS8 33

Appendix 2, Vessel Recordation Forms, 41CS14 37

Appendix 3, Vessel Recordation Forms, 41CS26 40

Appendix 4, Vessel Recordation Forms, 41MR12 45 


\section{LIST OF FIGURES}

Figure 1. Location of Lake Wright Patman, Lake O' the Pines, and Lake Sam Rayburn in northeastern Texas.

Figure 2. General map of the Snipes site and the location of prehistoric burials found there in archeological investigations.

Figure 3. Vessels from the Snipes site: a, Coles Creek Incised, var. Stoner; b-d, small, plain bowls.

Figure 4. Map of the Knight's Bluff site and the location of Burials 1-2, 4-11.

Figure 5. Vessels from Burial 4 at the Knight's Bluff site: a, Pease Brushed-Incised jar; b, brushed-punctated bowl; c, Antioch Engraved bottle.

Figure 6. Map of the Sherwin site showing the locations of Burials 1-8.

Figure 7. Ceramic vessels from the Sherwin site, Burials 4 and 6: a, plain carinated bowl; b-e, decorated jars; f, Haley Engraved bottle.

Figure 8. Excavations in the burial area at the Ben McKinney site.

Figure 9. Selected vessels from Burial I at the Ben McKinney site.

Figure 10. Selected vessels from Burial II at the Ben McKinney site.

Figure 11. Selected vessels from Burial III at the Ben McKinney site.

Figure 12. Selected vessels from the "line of artifacts" at the Ben McKinney site.

Figure 13. Elbow pipe from Burial III: a, looking down on the pipe bowl; b, looking sideways at the pipe stem and bowl.

Figure 14. Celts from burials at the Ben McKinney site: a, line of artifacts; b, Burial III.

Figure 15. Talco arrow points from Burials I and III at the Ben McKinney site: a-e, Burial III; f, Burial I.

Figure 16. Biface from Burial III at the Ben McKinney site.

Figure 17. Jars from the Pleasure Point site.

Figure 18. Carinated bowls from the Pleasure Point site.

Figure 19. Bottles from the Pleasure Point site.

Figure 20. Excavation area in the mound at the Jonas Short site.

Figure 21. Copper bracelets from Burial 2 at the Jonas Short site.

Figure 22. Fragments of thin hammered copper fragments from Cache 2 at the Jonas

Short site.

Figure 23. Perforated elk teeth from Cache 2.

Figure 24. Large dart point from Cache 2 at the Jonas Short site.

Figure 25. Biface from Cache 2 at the Jonas Short site.

Figure 26. Cache 1 boat stone.

Figure 27. Quartz crystals from the Jonas Short mound excavations, Caches 1 and 5.

Figure 28. Map of the Walter Bell site and the locations of Houses 1 and 2 and Burials 16.

Figure 29. Bird bone flageolet from Burial 6 at the Walter Bell site.

Figure 30. Coles Creek Incised, var. Stoner vessel from the Snipes site: a, side view; b, looking down at the incised lip line.

Figure 31. Burial 7 vessel from the Snipes site.

Figure 32. Burial 8 vessel from the Snipes site.

Figure 33. Burial 9 plain vessel from the Snipes site. 


\section{LIST OF FIGURES, cont.}

Figure 34. Pease Brushed-Incised vessel from Burial 4 at the Knight's Bluff site: a, photograph; b, drawing by Bobby Gonzalez.

Figure 35. Brushed-punctated vessel from Burial 4 at the Knight's Bluff site.

Figure 36. Antioch Engraved bottle from the Knight's Bluff site, Burial 4.

Figure 37. Burial 4 plain vessel from the Sherwin site.

Figure 38. Punctated jar from Burial 4 at the Sherwin site.

Figure 39. Pease Brushed-Incised jar from Burial 4 at the Sherwin site.

Figure 40. Nash Neck Banded jar from Burial 6 at the Sherwin site.

Figure 41. Second Nash Neck Banded jar from Burial 6 at the Sherwin site.

Figure 42. Haley Engraved bottle from Burial 6 at the Sherwin site.

Figure 43. FBR 2 vessel, Ripley Engraved, from the Ben McKinney site.

Figure 44. Ripley Engraved vessel MR12-36: a, photograph; b, drawing by Bobby

Gonzalez.

Figure 45. Effigy bowl, vessel MR12-37.

Figure 46. Simms Engraved vessel (MR12-38): a, side view; b, looking down on the rim. Figure 47. Drawing of the Simms Engraved vessel (MR12-38) by Bobby Gonzalez.

Figure 48. Plain bottle, MR12-39.

Figure 49. Wilder Engraved bottle, MR12-40.

Figure 50. Ripley Engraved vessel, MR12-41.

Figure 51. Ripley Engraved vessel from Burial II, MR12-42.

Figure 52. Taylor Engraved vessel from Burial I at the Ben McKinney site, MR12-43.

Figure 53. Taylor Engraved vessel from Burial III at the Ben McKinney site, MR12-44.

Figure 54. Ripley Engraved vessel (MR12-45) from Burial III at the Ben McKinney site. Figure 55. Compound engraved vessel with Simms Engraved and Hodges Engraved motifs, MR12-46.

Figure 56. Drawing of Simms-Hodges Engraved compound vessel, MR12-46: a, side view; b, showing the bottom of the Hodges Engraved portion of the vessel.

Figure 57. Cass Appliqued jar from Burial I, MR12-47.

Figure 58. Red-slipped Ripley Engraved vessel from Burial II, MR12-48.

Figure 59. Ripley Engraved, var. Walkers Creek vessel, MR12-49: a, side view; b, bottom view.

Figure 60. Drawing by Bobby Gonzalez of Ripley Engraved, var. Walkers Creek vessel: a, side view; $b$, bottom view.

Figure 61. Ripley Engraved vessel (MR12-50) from Burial II at the Ben McKinney site. Figure 62. Taylor Engraved vessel MR12-51 from Burial I at the Ben McKinney site. Figure 63. Ripley Engraved compound bowl, MR12-52, from Burial I at the Ben McKinney site.

Figure 64. Engraved and incised jar, MR12-53, from Burial III at the Ben McKinney site: a, photograph; b, drawing by Bobby Gonzalez.

Figure 65. Ripley Engraved vessel from Burial III at the Ben McKinney site, MR12-54. Figure 66. Vessel MR12-55, a Ripley-Taylor Engraved compound bowl from Burial I: a, photograph; b, drawing by Bobby Gonzalez.

Figure 67. Ripley Engraved vessel, MR12-56, from Burial I at the Ben McKinney site. Figure 68. Ripley Engraved vessel from Burial II at the Ben McKinney site (MR12-57). 


\section{LIST OF FIGURES, cont.}

Figure 69. Miniature engraved-punctated bowl (MR12-58) from Burial III at the Ben McKinney site.

Figure 70. Maydelle Incised jar from Burial III at the Ben McKinney site.

Figure 71. Simms Engraved carinated bowl from "line of artifacts" at the Ben McKinney site.

Figure 72. Engraved compound bowl from Burial III at the Ben McKinney site. Figure 73. Ripley Engraved carinated bowl from the "line of artifacts" at the Ben McKinney site.

Figure 74. Taylor Engraved bottle (MR12-65) from Burial I at the Ben McKinney site. Figure 75. Plain bottle, MR12-66, found south of Burial II at the Ben McKinney site. Figure 76. Bailey Engraved bottle from Burial III: a, side view; b, bottom view. Figure 77. Drawing of the Bailey Engraved bottle (MR12-67) by Bobby Gonzalez. Figure 78. Bailey Engraved bottle from Burial II at the Ben McKinney site. Figure 79. Harleton Appliqued jar from Burial III at the Ben McKinney site. Figure 80. Taylor Engraved vessel (MR12-72) from Burial I at the Ben McKinney site: a, side view; $b$, bottom view.

Figure 81. Drawing of Taylor Engraved carinated bowl from Burial I at the Ben McKinney site.

Figure 82. Ripley Engraved compound bowl from Burial I at the Ben McKinney site: a, side view; b, bottom view.

Figure 83. Ripley Engraved carinated bowl from Burial III at the Ben McKinney site. Figure 84. Taylor Engraved carinated bowl (MR12-75) from Burial I at the Ben McKinney site.

Figure 85. Ripley Engraved carinated bowl from Burial I at the Ben McKinney site. Figure 86. Harleton Appliqued jar (MR12-77) from Burial I at the Ben McKinney site. Figure 87. Harleton Appliqued jar from Burial III at the Ben McKinney site. Figure 88. Ripley Engraved carinated bowl from Burial III at the Ben McKinney site. Figure 89. Ripley Engraved carinated bowl (MR12-80) from Burial II at the Ben McKinney site.

Figure 90. Brushed-punctated jar (MR12-81) from Burial I at the Ben McKinney site. Figure 91. Engraved and red-slipped bottle or olla from Burial II at the Ben McKinney site.

Figure 92. Harleton Appliqued jar (MR12-103) from Burial II at the Ben McKinney site. Figure 93. Harleton Appliqued jar from Burial II at the Ben McKinney site.

Figure 94. Ripley Engraved carinated bowl (MR12-105) from Burial I at the Ben McKinney site: a, photograph; b, drawing by Bobby Gonzalez.

Figure 95. Taylor Engraved olla from Burial I (MR12-113) at the Ben McKinney site. 


\section{LIST OF TABLES}

Table 1. Vessels from the Snipes Site.

Table 2. Vessels from the Knight's Bluff Site. $\quad 6$

Table 3. Vessels from the Sherwin Site.

Table 4. Vessels from the Ben McKinney Site.

Table 5. Celts from the Ben McKinney site.

Table 6. Talco points from the Ben McKinney site.

Table 7. Vessels from the Pleasure Point Site.

Table 8. Copper Bracelets from the Jonas Short site. 


\section{ACKNOWLEDGMENTS}

The material provided in this report is based upon work assisted by a Native American Graves Protection and Repatriation Act (NAGPRA) grant awarded to the Caddo Nation by the National Park Service. The conclusions and recommendations expressed in this report are those of the authors and do not necessarily reflect the views of the National Park Service or the Department of the Interior.

First, we would like to recognize Colonel John R. Minahan (Fort Worth District, U.S. Army Corps of Engineers), along with Patience E. Patterson (Fort Worth District, U.S. Army Corps of Engineers), for the roles they played in supporting our grant proposal.

Our sincere appreciation goes to the staff of the Texas Archeological Research Laboratory (TARL) at The University of Texas at Austin, and especially to TARL's Director, Dr. Darrell G. Creel, Head of Collections, Laura Nightengale, and Head of Records, Carolyn Spock, for their assistance and in allowing us to examine the U.S. Army Corps of Engineers collections and records housed at TARL.

We would also like to thank our archeological consultants, Dr. Timothy K. Perttula, Rodney "Bo" Nelson, and Mark Walters. We greatly appreciate their continued support of, and participation in, our NAGPRA and Historic Preservation program at the Caddo Nation. A special thanks goes to Sandy Hannum, who prepared the various maps used in this report.

The Caddo Nation Tribal Council and Chairwoman LaRue Parker have continued to be supportive of all of our preservation and NAGPRA-related efforts, and we sincerely thank them.

As always, we cannot function as a preservation office without the support and input of our tribal elders, especially those on the Repatriation Committee who continue to guide us in our endeavors and provide us with their wisdom on these types of projects.

Lastly, we would like to than all of the staff members of the Caddo Nation who helped us bring this report together. We especially thank Mary Botone for her efforts inside and out of our office to make sure we can continue to accomplish all the things we set out to do as a preservation department.

Robert Cast and Bobby Gonzalez 


\section{INTRODUCTION AND PURPOSE OF THE STUDY}

This report concerns the documentation of unassociated Native American Graves Protection and Repatriation Act (NAGPRA) funerary objects from prehistoric sites at several man-made reservoirs operated by the U.S. Army Corps of Engineers, Fort Worth District (COE) in northeastern Texas: Lake Wright Patman, Lake O' the Pines, and Lake Sam Rayburn in the Sulphur River, Big Cypress Creek, and Angelina River basins, respectively (Figure 1). These NAGPRA materials are presently held at the Texas Archeological Research Laboratory at The University of Texas at Austin (TARL).

Figure 1. Location of Lake Wright Patman, Lake O' the Pines, and Lake Sam Rayburn in northeastern Texas.

\section{NAGPRA COLLECTIONS}

The COE NAGPRA collection of unassociated funerary objects are from seven prehistoric sites at the aforementioned northeastern Texas reservoirs. Most of the NAGPRA funerary objects are whole ceramic vessels $(n=73)$ from the Snipes (41CS8, n=4), Knights Bluff (41CS14, n=3), Sherwin (41CS26, n=6), Ben McKinney (41MR12, $\mathrm{n}=48$ ), and Pleasure Point (41MR63, $\mathrm{n}=12$ ) sites. Other funerary offerings in the COE NAGPRA collection of unassociated funerary objects include elbow pipes, kaolin clay masses, celts, pitted stones, a boat stone, quartz crystals, arrow points, dart points, bifaces, copper bracelets, fragments from a copper gorget, perforated elk teeth, and a bird bone flageolet. Each of these different kinds of funerary objects are discussed in the context of the archeological findings from the five sites listed above, along with the findings from the Jonas Short (41SA101) and Walter Bell (41SB50) sites at Lake Sam Rayburn.

\section{Study of the Ceramic Vessels}

Because of the number of ceramic vessels in the COE NAGPRA collections, we established a documentation protocol to assist in the study of each of the vessels. Each of the ceramic vessels in the collections is described and illustrated utilizing a consistent set of ceramic morphological, functional, and stylistic attributes modeled after the presentation in Gadus and Fields (1996) for the Titus phase Pleasure Point site (41MR63), Perttula et al. (1998) for the Titus phase Mockingbird site (41TT550), Perttula and Sherman (2009) for the Ear Spool site (41TT653), and Perttula (2005, ed.) for the Pilgrim's Pride (41CP304) vessel assemblage. The purpose of the documentation is to thoroughly characterize the assemblage of ceramic vessels in the collections. Appendix 1-4 are the completed vessel recordation forms from the Snipes, Knights Bluff, Sherwin, and Ben McKinney sites; see Gadus and Fields (1996) for the detailed recordation of the ceramic vessels from the Pleasure Point site.

Vessel illustrations include a photograph of each vessel, along with an accompanying drawing in several cases, to better portray their decoration, shape, and 
surface texture. In the case of the Ben McKinney site ceramic vessels, engraved design motifs on bowls, compound bowls, and bottles are also compared with Ripley Engraved motifs defined by Thurmond (1990:Figure 6), and with specific published Titus phase vessel assemblages (see Cast et al. 2006; Gadus and Fields 1996; Perttula 2006a, 2006b; Perttula et al. 1998; Perttula et al. 1993; Perttula 2005, ed.; Rogers et al. 2003; Thurmond 1990; Turner 1978).

The following attributes were employed in this ceramic vessel study:

Non-plastics: Deliberate and indeterminate materials in the paste (Rice 1987:411), including a variety of tempers (grog or crushed sherds, bone, hematite, shell, quartz sands, etc.) and "particulate matter of some size." The grog, bone, and hematite non-plastics appear to have been deliberately added to the paste as tempers. The bone used for temper had been burned and calcined, then crushed, before it was added to the paste.

Vessel Form: Vessel form categories include open containers (bowls, carinated bowls, and compound bowls) and restricted containers, including jars and bottles. As restricted containers, jars allow access by hand, but bottles do not (Brown 1996:335). One of the vessels is a compound form, one where two different vessel forms have been conjoined to create a single unique vessel form. This ceramic practice is one of the distinctive features of Titus phase ceramic vessel assemblages. Other form attributes that were recorded include the rim profile (outflaring or everted, vertical or standing, and inverted), lip profile (rolled to the exterior, rounded, flat, or thinned), and base shape (flat or rounded).

Core Colors: Observations on ceramic cross-section colors permit consideration of oxidation patterns (Teltser 1993:Figure 2A-H), and thus the conditions under which the vessel was fired and then cooled after firing. Comments are included for these attributes on the presence and location of fire-clouding, sooting or smudging from cooking use (Skibo 1992), and charred organic remains.

Wall Thickness: Thickness was recorded in millimeters, using a vernier caliper, at the lip, along the rim, at several points along the body, and at the base when possible (only for the vessels that were not complete).

Interior and Exterior Surface Treatment: The primary methods of finishing the surface of the vessel include smoothing, burnishing, and polishing (Rice 1987:138). Brushing, while a popular method of roughening the surface (particularly the body) of large and small Middle (ca. A.D. 1200-1400) and Late Caddo (ca. A.D. 1400-1680) period cooking jars, is here considered a decorative treatment rather than solely a functional surface treatment (cf. Rice 1987:138), although not all Caddo ceramic analysts treat brushing as a decorative treatment (cf. Gadus et al. 2006:31). Smoothing creates "a finer and more regular surface... [and] has a matte rather than a lustrous finish" (Rice 1987:138). Burnishing, on the other hand, creates an irregular lustrous finish marked by 
parallel facets left by the burnishing tool (perhaps a pebble or bone). A polished surface treatment is marked by a uniform and highly lustrous surface finish, done when the vessel is dry, but without "the pronounced parallel facets produced by burnishing leather-hard clay” (Rice 1987:138).

The application of a hematite-rich clay slip (Ferring and Perttula 1987), either red or black after firing in an oxidizing or reducing (i.e., low-oxygen) environment, is another form of surface treatment noted in this assemblage. The clay slip is more frequently applied on the vessel exterior than on the interior surface, and then was either burnished or polished after it was leather-hard or dry.

Height and Orifice Diameter: These attributes, measured in centimeters, were recorded with a ruler.

Diameter at Bottom of Rim and Base Diameter: Also recorded in millimeters using a ruler, these attributes permit characterization of the overall contour and shape of the vessel.

Volume: Vessel volume in liters was determined by filling (to within $1 \mathrm{~mm}$ of the lip) the vessel with lentil seeds, then dumping the lentil seeds in containers of known volume. In estimating the volume of vessels with holes, the vessel was first filled with a cloth that conformed to vessel contours, then the lentil seeds were poured into the depression in the cloth to within $1 \mathrm{~mm}$ of the top of the lip. Then they were dumped into containers of known volume. In cases where the vessels were not (or could not be) reconstructed, but measurements of height and orifice diameter were be obtained, volumes were estimated by comparison with known vessel volumes of specific forms (i.e., carinated bowl, jar, bottle, compound bowl, and bowl) in other documented Caddo vessel assemblages.

Decoration: Decorative techniques present in the TARL NAGPRA vessel collection from COE sites in northeastern Texas include engraving, incising, punctating, brushing, neck banding, and appliquéing, and on certain vessels, combinations of decorative techniques (i.e., brushed-punctated) created the decorative elements and motifs. Engraving was done with a sharp tool when the vessel was either leather-hard, or after it was fired, while the other decorative techniques were executed with tools (incising and punctation), by adding strips of clay to the wet body (appliqué), by crimping the coils (neck banding), using frayed sticks or grass stems (brushing) dragged across the body surface, or fingernails (certain forms of punctations), when the vessel was wet or still plastic. Excising is considered a form of engraved decoration, where the clay is deliberately and closely marked/scraped and carved away with a sharp tool, usually to create triangular elements (the pendant triangle) or crescent-shaped elements separating or defining scrolls (Suhm and Jelks 1962:Plate 64a-b, f).

The classification of decorative motifs for the Ripley Engraved bowls follows Thurmond's (1990:Figure 6) work. Another form of Titus phase vessel 
decoration is the use of red (hematite or ochre) or white (kaolin clay) clay pigments that have been smeared or rubbed into the engraved lines of certain vessels.

Type: The kinds of ceramic types in the COE NAGPRA collections follow Suhm and Jelks (1962), Jelks (1961, 1965), Turner (1978), and Perttula (2005, ed.).

\section{Snipes Site (41CS8)}

The Snipes site (41CS8) was excavated by Jelks (1961) in 1952 as part of the River Basins Surveys (RBS) program administered by the Smithsonian Institution in cooperation with the National Park Service, the U.S. Army Corps of Engineers, and the Bureau of Reclamation. Snipes was one of three sites excavated by the RBS prior to the inundation of a large part of the Sulphur River valley by Texarkana Reservoir, now Lake Wright Patman. The Snipes site was apparently occupied in the Woodland period (ca. 500 B.C.-A.D. 800), and can be considered a component of the Fourche Maline Culture (Schambach 1998, 2002:Figure 5.1) on the basis of the artifacts recovered from both habitation archeological deposits and burial features.

During the work at the site by Jelks, nine prehistoric burials were excavated there (Figure 2), including three (Burials 7-9) that were discovered an unknown distance northeast of Burials 1-6 (Jelks 1961:46) during the last round of work at the site. In the present study, the funerary objects of concern were found with Burials 6-9. Jelks (1961:45-46) reported that traces of human remains from adults of unknown sex were present in Burials 6 and 7, but failed to mention if such was the case for Burials 8 and 9. However, since Burial 8 was reported to have contained two individuals, and the orientation of the heads was recorded (Jelks 1961:46), human remains (again, probably from adults, although not noted) were obviously preserved in this burial as well, but apparently not recovered. For Burial 9, Jelks (1961:46) simply noted that preservation "was poor."

Figure 2. General map of the Snipes site and the location of prehistoric burials found there in archeological investigations.

Burials 6, 7, and 8 contained individuals that were placed in the grave in an extended supine (i.e., on their back) position. Burial 8 had two individuals in extended supine position. The position of the deceased individual in Burial 9 was not recorded. Burial 6 had a Coles Creek Incised, var. Stoner bowl by the right shoulder of the deceased, and one small bowl had been placed as a funerary offering in Burials 7-9; in two instances, the small bowls were by the left shoulder of the deceased.

\section{Vessels}

There are four vessels in the present COE NAGPRA collections (Table 1). All four are grog-tempered. One is a large barrel-shaped Coles Creek Incised, var. Stoner vessel, dated from ca. A.D. 550-700 (Brown 1998:8, 53) (Figure 3a), and the others are 
small (0.12-0.25 liters) plain bowls (Figure 3b-d). Story (1990:304) suggests the latter vessels are examples of Williams Plain, but they have thin walls (less than $4.0 \mathrm{~mm}$ in thickness), whereas typical Williams Plain vessels are flower-pot shaped vessels with thick (> 8.0-10.0 mm) body walls (Schambach 1998, 2002). Nevertheless, the Coles Creek Incised vessel provides confirmatory evidence that the burials from the Snipes site were interred during the latter part of the Woodland period.

Table 1. Vessels from the Snipes Site.

\begin{tabular}{|c|c|c|c|c|c|c|}
\hline Vessel No. & Temper & $\begin{array}{l}\text { Height } \\
(\mathrm{cm})\end{array}$ & $\begin{array}{l}\text { Orifice Diameter } \\
(\mathrm{cm})\end{array}$ & $\begin{array}{l}\text { Volume } \\
\text { (liters) }\end{array}$ & Decoration & Type \\
\hline \multicolumn{7}{|c|}{ Barrel-shaped bowl } \\
\hline 2 & grog & 19.1 & 14.0 & 2.1 & $\begin{array}{l}\text { single overhanging } \\
\text { incised line and incised } \\
\text { lip line }\end{array}$ & $\begin{array}{l}\text { Coles Creek } \\
\text { Incised, var. } \\
\text { Stoner }\end{array}$ \\
\hline \multicolumn{7}{|l|}{ Bowl } \\
\hline 3 & grog & 6.1 & 9.4 & 0.25 & Plain & Undetermined* \\
\hline 4 & grog & 3.3 & 9.8 & 0.12 & Plain & Undetermined* \\
\hline 5 & grog & 4.3 & 6.5 & 0.12 & Plain & Undetermined* \\
\hline
\end{tabular}

*Story (1990:304) identifies these vessels as Williams Plain

Figure 3. Vessels from the Snipes site: a, Coles Creek Incised, var. Stoner; b-d, small, plain bowls.

\section{Knight's Bluff Site (41CS14)}

Ten burials were excavated at the Knight's Bluff site by Jelks (1961) in two different small prehistoric cemeteries on either side of a Caddo structure (Figure 4). The burial of concern in this study is Burial 4 in the northern cemetery. The kind and range of artifacts recovered in habitation and burial features at the Knight's Bluff site indicate that it was occupied during the Middle Caddo period (Cliff 1997; Perttula 1998).

Figure 4. Map of the Knight's Bluff site and the location of Burials 1-2, 4-11.

Burial 4 was described by Jelks (1961:18) as that of an extended individual-an adult female, about 20 years of age, with classic Caddo fronto-occipital cranial deformation (cf. Derrick and Wilson 1997). There were three vessels placed with the deceased, namely to the right of the head and shoulder. Although the U. S. Army Corps of Engineers, Fort Worth District (2004:316) considered these three vessels to be unassociated funerary objects, their direct association with well-preserved human remains (Jelks 1961:18) indicates that they should be considered associated funerary objects under NAGPRA. 


\section{Vessels}

The three moderately-sized vessels placed by the Caddo with Burial 4 include a Pease Brushed-Incised jar, a brushed-punctated bowl, and an Antioch Engraved bottle (Figure 5a-c and Table 2). All three vessels were tempered with grog.

Figure 5. Vessels from Burial 4 at the Knight's Bluff site: a, Pease Brushed-Incised jar; b, brushed-punctated bowl; c, Antioch Engraved bottle.

Table 2. Vessels from the Knight's Bluff Site.

\begin{tabular}{|c|c|c|c|c|c|}
\hline Vessel No. & Temper & $\begin{array}{l}\text { Height } \\
(\mathrm{cm})\end{array}$ & $\begin{array}{l}\text { Orifice Diameter } \\
(\mathrm{cm})\end{array}$ & $\begin{array}{l}\text { Volume Decoration } \\
\text { (liters) }\end{array}$ & Type \\
\hline \multicolumn{6}{|l|}{$\underline{\text { Jar }}$} \\
\hline 6995 & grog & 18.3 & 12.7 & incised-appliqued & $\begin{array}{l}\text { Pease Brushed- } \\
\text { Incised }\end{array}$ \\
\hline
\end{tabular}

$\underline{\text { Bowl }}$

6996

$\operatorname{grog} \quad 8.9 \quad 10.2$

$0.7 \quad$ brushed-punctated

Brushedpunctated utility ware

Bottle

6997

$\operatorname{grog} \quad 12.7 \quad 3.3$

0.3 engraved

Antioch

Engraved

\section{Sherwin Site (41CS26)}

The Sherwin site was also occupied during the Middle Caddo period (ca. A.D. 1200-1400) (Cliff 1997). It is a habitation site with a large midden deposit (Jelks 1961:57) that had probably accumulated inside a structure. During Jelks' (1961:Figure 8) excavations at the Sherwin site, a total of eight prehistoric burials were excavated, six in a small cemetery at the northern end of the site (Figure 6) and Burials 3 and 8 some distance to the south and southeast.

Figure 6. Map of the Sherwin site showing the locations of Burials 1-8.

Burials 4 and 6 are the subject of this study because they, along with the funerary objects, were identified by the U.S. Army Corps of Engineers (2004:317) as burials of unknown affiliation with several unassociated funerary objects. Jelks (1961:58-59) indicates, however, that both burials contained preserved human remains, namely "a few bone scraps" in Burial 4 and the "skull and traces of long bones" in Burial 6. Both burials were those of adults. Burial 4 had four ceramic vessels (including a bottle that is on loan 
and not documented as part of this study), and three ceramic vessels were placed with Burial 6. The position of the vessels in Burial 4 was not provided by Jelks (1961:58), but in Burial 6, two jars were by the left shoulder and left knee, and a bottle had been placed near the right knee (Jelks 1961:59).

\section{Vessels}

The six vessels from the Sherwin site in the TARL collections include one plain carinated bowl, four decorated jars, and a Haley Engraved bottle (Table 3 and Figure 7af). The one missing vessel is a small engraved bottle (Jelks 1961:58). All the vessels are small in size, with volumes ranging from only 0.2-0.6 liters (Table 3).

\section{Table 3. Vessels from the Sherwin Site.}

\begin{tabular}{|c|c|c|c|c|c|c|}
\hline Vessel No. & Temper & $\begin{array}{l}\text { Height } \\
(\mathrm{cm})\end{array}$ & $\begin{array}{l}\text { Orifice Diameter } \\
(\mathrm{cm})\end{array}$ & $\begin{array}{l}\text { Volum } \\
\text { (liters) }\end{array}$ & Decoration & Type \\
\hline \multicolumn{7}{|c|}{ Carinated bowl } \\
\hline $2041 *$ & $\begin{array}{l}\text { grog- } \\
\text { bone }\end{array}$ & 5.6 & 8.1 & 0.2 & plain & Undetermined \\
\hline \multicolumn{7}{|l|}{$\underline{\mathrm{Jar}}$} \\
\hline $2042 *$ & UID & 8.3 & 6.6 & 0.3 & tool punctated & Undetermined \\
\hline $2043 *$ & $\begin{array}{l}\text { grog- } \\
\text { bone }\end{array}$ & 8.2 & 7.7 & 0.37 & & $\begin{array}{l}\text { Pease Brushed- } \\
\text { Incised }\end{array}$ \\
\hline $2045^{* *}$ & $\begin{array}{l}\text { grog- } \\
\text { bone }\end{array}$ & 11.7 & 8.7 & 0.6 & neck banded-punctated & \\
\hline $2046 * *$ & grog & 9.1 & 5.7 & 0.3 & neck banded & $\begin{array}{l}\text { Nash Neck } \\
\text { Banded }\end{array}$ \\
\hline \multicolumn{7}{|l|}{$\underline{\text { Bottle }}$} \\
\hline $2047 * *$ & $\begin{array}{l}\text { grog- } \\
\text { hematite }\end{array}$ & 15.2 & 3.6 & 0.3 & engraved & Haley Engraved \\
\hline \multicolumn{7}{|c|}{ *Burial 4; **Burial 6; UID=unidentified } \\
\hline \multicolumn{7}{|c|}{$\begin{array}{l}\text { Figure } 7 \text {. Ceramic vessels from the Sherwin site, Burials } 4 \text { and 6: a, plain carinated bowl; } \\
\text { b-e, decorated jars; f, Haley Engraved bottle. }\end{array}$} \\
\hline \multicolumn{7}{|c|}{$\begin{array}{l}\text { Unlike the ceramic vessels from the Snipes and Knight's Bluff site, those from } \\
\text { Burials } 4 \text { and } 6 \text { at the Sherwin site include several tempered with both grog and bone } \\
(\mathrm{n}=3) \text { and one tempered with grog and hematite (see Table } 3 \text { ). The grog and grog-bone- } \\
\text { tempered Nash Neck Banded jars may be an early variety of this utility ware, as later, } \\
\text { post-A.D. } 1400 \text { neck banded vessels in this area and on the Red River (affiliated with the } \\
\text { Texarkana, Belcher, and McCurtain phases) tend to be shell-tempered (Suhm and Jelks } \\
\text { 1962:111; Perttula 2005:194). }\end{array}$} \\
\hline
\end{tabular}




\section{Ben McKinney Site (41MR12)}

The Ben McKinney site was excavated by University of Texas at Austin archeologists in 1957 prior to the completion of Lake O' the Pines (Davis and Golden 1960). The site was not inundated by the completed lake, however, and signs of the nonbackfilled 1950s excavations are still visible in the excavation area. The site and its associated cemetery was occupied during the Late Caddo Titus phase (Perttula, ed., 2005: Table 11-4), probably after ca. A.D. 1550.

During the 1957 work, three burials (Burials I-III) were excavated and fully documented (Figure 8) by the University of Texas archeologists, and seven others were excavated by either local avocational archeologists (Burials IV-VII) or unknown others (pits from previous digging shown on Figure 8). There is at least one other burial (Davis and Golden 1960:14) marked by a "line of artifacts" in the southern part of the burial excavation area that was also documented by the University of Texas archeologists.

Figure 8. Excavations in the burial area at the Ben McKinney site.

The funerary objects of concern for this study are from Burials I, II, and III, as well as from the "line of artifacts." In no case was there any preserved skeletal materials found in association with the funerary offerings, but burial pit outlines were demarcated for Burials I-III but not for the "line of artifacts." The size of the burial pits, ranging from 2.8-3.2 $\mathrm{m}$ in length and 1.0-1.2 $\mathrm{m}$ in width, are consistent with burial pits employed to inter Titus phase Caddo adults. The "line of artifacts" is almost $5.5 \mathrm{~m}$ in length (see Figure 8), lending support to Davis and Golden's (1960:14) suggestion that these funerary objects are from at least one grave, and probably two.

The burial pits and the "line of artifacts" have a northeast-southwest orientation, and it is likely based on studies of other Titus phase burials that had preserved skeletal remains (cf. Turner 1978, 1992; Turner et al. 2002; Perttula, ed., 2005) that the deceased individual was laid on their back in an extended position, with their head facing to the southwest. A common feature of Titus phase Caddo burials was to place a ceramic bottle near or next to the head of the deceased individual. In the case of Burials I-III, bottles were interred near the eastern end of the three burial pits (Davis and Golden 1960:

Figures 5, 7, and 9), and thus it is likely that the deceased's head rested in that end of the pit and faced towards the west or southwest, following the orientation of the burial pit. Other funerary objects in Titus phase burials tended to be placed in rows down the sides of the body, and extending in some instances to the foot area, and such is evidenced in the placement of funerary objects in Burials I-III and the "line of artifacts" burial area.

Funerary objects recovered from Burials I-III and the "line of artifacts" include 48 ceramic vessels, an elbow pipe in Burial III, kaolin clay masses in Burial II, a celt, two bifaces, and six Talco arrow points from two burials (see below). Also found in the burial area excavations were two pitted stones, a Yarbrough dart point, and an isolated celt (south of Burial IV) (see Figure 8). 


\section{Vessels}

As previously mentioned, a total of 47 ceramic vessels were recovered from Burials I-III and the "line of artifacts," and there was another ceramic vessel labeled as FBR2 (described in the inventory records as the "Discovery Vessel") (Table 4). Its exact location within the burial area is not known. Burial I had 15 vessels (Figure 9a-i), Burial II had 10 (Figure 10a-f), and Burial III had 13 vessels (Figure 11a-h). The other nine are from the "line of artifacts" (Figure 12a-d) or other locations within the burial area (i.e., a plain bottle, 41MR12-66 or F154 on Figure 8, south of Burial II).

Table 4. Vessels from the Ben McKinney Site.

$\begin{array}{ccccc}\text { Vessel No. } & \text { Temper Height } \\ (\mathrm{cm}) & (\mathrm{cm}) & \begin{array}{l}\text { Orifice Diameter Volume Decoration } \\ \text { (liters) }\end{array} & \text { Type }\end{array}$

\begin{tabular}{|c|c|c|c|c|c|c|}
\hline \multicolumn{7}{|c|}{ Carinated bowl } \\
\hline FBR2 & grog & 10.5 & 21.7 & 1.4 & engraved & Ripley Engraved \\
\hline MR12-36 & bone & 8.5 & 14.2 & 0.7 & engraved & Ripley Engraved \\
\hline MR12-38 & $\begin{array}{l}\text { grog- } \\
\text { bone }\end{array}$ & 11.7 & 15.2 & 1.1 & engraved & Simms Engraved \\
\hline MR12-41 & none & 13.5 & 22.0 & 2.6 & engraved & Ripley Engraved \\
\hline MR12-42 & grog & 7.5 & 14.0 & 0.8 & engraved & Ripley Engraved \\
\hline MR12-43 & grog & 7.6 & 13.0 & 0.6 & engraved & Taylor Engraved \\
\hline MR12-44 & $\begin{array}{l}\text { grog- } \\
\text { bone }\end{array}$ & 6.4 & 14.2 & 0.55 & engraved & Taylor Engraved \\
\hline MR12-45 & $\begin{array}{l}\text { grog- } \\
\text { bone }\end{array}$ & 7.3 & 12.7 & 0.55 & engraved & Ripley Engraved \\
\hline MR12-48 & grog & 6.5 & 14.4 & 0.6 & engraved & Ripley Engraved \\
\hline MR12-49 & $\begin{array}{l}\text { grog- } \\
\text { bone }\end{array}$ & 8.3 & 21.1 & 1.1 & engraved-incised & $\begin{array}{l}\text { Ripley Engraved, } \\
\text { var. Walkers } \\
\text { Creek }\end{array}$ \\
\hline MR12-50 & grog & 12.8 & 24.4 & 1.9 & engraved & Ripley Engraved \\
\hline MR12-51 & $\begin{array}{l}\text { grog- } \\
\text { bone }\end{array}$ & 11.2 & 19.1 & 1.3 & engraved & Taylor Engraved \\
\hline MR12-56 & grog & 7.5 & 18.5 & 0.8 & engraved & Ripley Engraved \\
\hline MR12-57 & grog & 7.9 & 17.1 & 0.8 & engraved & Ripley Engraved \\
\hline MR12-60 & $\begin{array}{l}\text { grog- } \\
\text { bone }\end{array}$ & 10.5 & 15.3 & 1.0 & engraved & Simms Engraved \\
\hline MR12-63 & grog & 6.0 & 14.5 & 0.5 & engraved & Ripley Engraved \\
\hline MR12-72 & bone & 6.7 & 15.0 & 0.6 & engraved-punctated & Taylor Engraved \\
\hline MR12-74 & grog & 10.5 & 20.9 & 1.3 & engraved & Ripley Engraved \\
\hline MR12-76 & grog & 14.5 & 24.3 & 3.1 & engraved & Ripley Engraved \\
\hline MR12-79 & $\begin{array}{l}\text { grog- } \\
\text { organic }\end{array}$ & 11.0 & 24.2 & 1.6 & engraved & Ripley Engraved \\
\hline MR12-105 & grog & 14.5 & 23.9 & 3.1 & engraved & Ripley Engraved \\
\hline \multicolumn{7}{|c|}{ Compound Bowl } \\
\hline MR12-52 & $\begin{array}{l}\text { grog- } \\
\text { bone }\end{array}$ & 27.2 & 27.5 & 6.0 & engraved & Ripley Engraved \\
\hline
\end{tabular}


Table 4, cont.

Vessel No. Temper Height Orifice Diameter Volume Decoration Type $(\mathrm{cm}) \quad(\mathrm{cm}) \quad$ (liters)

Compound Bowl, cont.

MR12-55

$\begin{array}{lll}\begin{array}{l}\text { grog- } \\ \text { bone- }\end{array} & 11.2 & 11.8 \\ \text { hematite } & & \\ \text { grog } & 13.5 & 23.5 \\ \text { grog- } & 10.5 & 17.9 \\ \text { bone- } & & \\ \text { hematite } & & \end{array}$

1.1 engraved

Ripley-Taylor

Engraved

MR12-61

MR12-73

Bowl

\begin{tabular}{|c|c|c|c|c|c|c|}
\hline MR12-37 & $\begin{array}{l}\text { grog- } \\
\text { bone }\end{array}$ & 6.1 & 11.4 & 0.3 & plain & $\begin{array}{l}\text { possible effigy } \\
\text { bowl }\end{array}$ \\
\hline MR12-54 & grog & 7.5 & 13.8 & 0.4 & engraved & Ripley Engraved \\
\hline MR12-58 & $\begin{array}{l}\text { grog- } \\
\text { hematite }\end{array}$ & 2.6 & 6.6 & 0.07 & engraved-punctated & Taylor Engraved? \\
\hline MR12-75 & $\begin{array}{l}\text { grog- } \\
\text { bone }\end{array}$ & 10.5 & 22.2 & 1.4 & engraved & Taylor Engraved \\
\hline MR12-80 & $\begin{array}{l}\text { grog- } \\
\text { bone- } \\
\text { hematite }\end{array}$ & 13.2 & 24.4 & 2.9 & engraved & Ripley Engraved \\
\hline \multicolumn{7}{|l|}{$\underline{\mathrm{Jar}}$} \\
\hline MR12-47 & $\begin{array}{l}\text { grog- } \\
\text { bone }\end{array}$ & 14.0 & 10.2 & 0.85 & $\begin{array}{l}\text { punctated- } \\
\text { appliqued }\end{array}$ & Cass Appliqued \\
\hline MR12-53 & $\begin{array}{l}\text { grog- } \\
\text { bone }\end{array}$ & 15.5 & 10.0 & 0.9 & engraved-incised & Taylor Engraved? \\
\hline MR12-59 & grog & 32.2 & 29.0 & 12.1 & incised-brushed & Maydelle Incised \\
\hline MR12-71 & grog & 19.0 & 19.0 & 3.2 & $\begin{array}{l}\text { punctated-incised- } \\
\text { appliqued }\end{array}$ & $\begin{array}{l}\text { Harleton } \\
\text { Appliqued }\end{array}$ \\
\hline MR12-77 & $\begin{array}{l}\text { grog- } \\
\text { bone }\end{array}$ & 15.0 & 11.4 & 1.0 & incised-appliqued & $\begin{array}{l}\text { Harleton } \\
\text { Appliqued }\end{array}$ \\
\hline MR12-78 & bone & 14.4 & 18.0 & 1.5 & appliqued-brushed & $\begin{array}{l}\text { Harleton } \\
\text { Appliqued }\end{array}$ \\
\hline MR12-81 & $\begin{array}{l}\text { grog- } \\
\text { bone }\end{array}$ & 22.5 & 21.5 & 4.3 & brushed-punctated & $\begin{array}{l}\text { Undetermined } \\
\text { utility ware }\end{array}$ \\
\hline MR12-103 & $\begin{array}{l}\text { grog- } \\
\text { bone }\end{array}$ & N/A & 16.0 & $\mathrm{~N} / \mathrm{A}$ & appliqued & $\begin{array}{l}\text { Harleton } \\
\text { Appliqued }\end{array}$ \\
\hline MR12-104 & grog & 17.3 & 15.5 & 2.4 & appliqued-incised & $\begin{array}{l}\text { Harleton } \\
\text { Appliqued }\end{array}$ \\
\hline \multicolumn{7}{|l|}{$\underline{\text { Bottle }}$} \\
\hline MR12-39 & $\begin{array}{l}\text { grog- } \\
\text { bone }\end{array}$ & 9.5 & 3.2 & 0.16 & plain & Undetermined \\
\hline MR12-40 & grog & 9.9 & 2.5 & 0.19 & engraved & Wilder Engraved \\
\hline
\end{tabular}


Table 4, cont.

\begin{tabular}{|c|c|c|c|c|c|c|}
\hline Vessel No. & Temper & $\begin{array}{l}\text { Height } \\
(\mathrm{cm})\end{array}$ & $\begin{array}{l}\text { Orifice Diameter } \\
(\mathrm{cm})\end{array}$ & $\begin{array}{l}\text { Volume } \\
\text { (liters) }\end{array}$ & Decoration & Type \\
\hline \multicolumn{7}{|l|}{ Bottle, cont. } \\
\hline MR12-65 & grog & 10.1 & 3.4 & 0.17 & engraved & Taylor Engraved \\
\hline MR12-66 & bone & $7.4+$ & 2.8 & $>0.17$ & plain & Undetermined \\
\hline MR12-67 & none & 15.6 & 4.0 & 0.4 & engraved-punctated & Bailey Engraved \\
\hline MR12-68 & $\begin{array}{l}\text { grog- } \\
\text { hematite }\end{array}$ & 22.0 & 3.4 & 0.7 & engraved-punctated & Bailey Engraved \\
\hline MR12-102 & grog & 16.0 & 6.2 & 0.4 & engraved & Taylor Engraved? \\
\hline \multicolumn{7}{|l|}{$\underline{\text { Olla }}$} \\
\hline MR12-113 & grog- & 19.8 & 8.4 & 1.2 & engraved & Taylor Engraved \\
\hline \multicolumn{7}{|c|}{ Compound vessel } \\
\hline MR12-46 & grog & 13.0 & 8.4 & 0.65 & engraved & $\begin{array}{l}\text { Simms-Hodges } \\
\text { Engraved }\end{array}$ \\
\hline
\end{tabular}

Figure 9. Selected vessels from Burial I at the Ben McKinney site: a, MR12-47; b, MR12-51; c, MR12-52; d, MR12-55; e, MR12-65; f, MR12-72; g, MR12-75; h, MR1277; i, MR12-113.

Figure 10. Selected vessels from Burial II at the Ben McKinney site: a, MR12-42; b, MR12-48; c, MR12-49; d, MR12-57; e, MR12-68; f, MR12-104.

Figure 11. Selected vessels from Burial III at the Ben McKinney site: a, MR12-44; b, MR12-46; c, MR12-53; d, MR12-59; e, MR12-61; f, MR12-67; g, MR12-78; h, MR12102.

Figure 12. Selected vessels from the "line of artifacts" at the Ben McKinney site: a, MR12-36; b, MR12-38; c, MR12-41; d, MR12-60.

These vessels have a variety of forms and sizes. The most prevalent vessel form is the carinated bowl ( $n=21$ or 44 percent, see Figures 9b, f, 10a-d, 11a, and 12a-d). The frequency of engraved carinated bowls, especially Ripley Engraved carinated bowls is completely consistent with other Titus phase vessel assemblages from burial contexts (Perttula, ed., 2005: Table 11-10). These vessel forms are decorated with engraved motifs of the Ripley Engraved $(n=15)$, Simms Engraved $(n=2)$, and Taylor Engraved $(n=4)$ types. These vessels occur in at least three size classes: less than 0.8 liters, 1.1-1.9 liters, and 2.6-3.1 liters. More than 80 percent of the carinated bowls are tempered with grog (see Table 4), but 38 percent also have bone temper, either as the sole temper aplastic or in combination with grog. 
Jars account for almost 19 percent of the vessels in the COE NAGPRA collections (see Table 4 and Figures 9a, h, 10f, and 11c-d, g). With the exception of the one engraved-incised jar from Burial III (see Figure 11c), the other jars have wet paste decorations (i.e., decorations applied prior to the firing of the vessel) commonly seen on Caddo utility ware vessels, including Harleton Appliqued $(n=5)$, Maydelle Incised $(n=1)$, Cass Appliqued $(\mathrm{n}=1)$, and a brushed-punctated vessel of undetermined typological classification. The jars include small (less than 1 liter), medium (1.5-3.2 liters), and large (4.3-12.1 liters) sizes (see Table 4). About 89 percent of the jars are tempered with grog, and one Harleton Appliqued jar is tempered solely with burned bone. Of the jars tempered with grog, 62.5 percent also have bone temper inclusions.

There are seven bottles in the COE NAGPRA collections from the Ben McKinney site (see Table 4 and Figures 9e, 10e, 11f, h). Two are plain and the others have engraved (Wilder Engraved and Taylor Engraved) or engraved-punctated (Bailey Engraved) decorations on the bottle bodies. The bottles range from small in size $(<0.19$ liters $)$ and height (ca. $10 \mathrm{~cm}$ or less) to large in size (0.7 liters) and height $(22.0 \mathrm{~cm})$ (see Table 4$)$. The bottles are tempered with grog $(n=3)$, grog-bone $(n=1)$, bone $(n=1)$, and groghematite $(n=1)$; one Bailey Engraved bottle has no apparent temper.

The five bowls are an interesting assortment of fine wares, with one plain effigy bowl, two Ripley Engraved vessels, and two Taylor Engraved vessels (see Table 4 and Figure 9g). The bowls are either very small - almost miniature-sized (less than 0.4 liters) - or medium-sized (1.4-2.9 liters). One bowl is tempered with grog, two have grog-bone temper, another has grog-hematite temper, and one of the Ripley Engraved bowls has grog, bone, and hematite temper inclusions.

Compound bowls comprise 8.3 percent of the COE NAGPRA vessels from the Ben McKinney site (see Table 4 and Figures $9 c-d$ and 11e). These are medium to large vessels decorated with engraved motifs, including two Ripley Engraved vessels, a third with both Ripley and Taylor Engraved designs on the two compound bowl rim panels, and a fourth compound bowl (see Figure 11e) with unique circular and triangular engraved elements. One of the compound bowls is tempered with grog, two have grog and bone temper, and the last vessel has grog, bone, and hematite temper inclusions.

There is one Taylor Engraved olla from Burial I at the Ben McKinney site (see Figure 9i). It is medium-sized (1.2 liters in volume) and tempered with grog. The olla form is not at all common in Titus phase vessel assemblages from mortuary contexts, comprising 0.9 percent of a sample of 2035 vessels from 17 well-documented sites (see Perttula, ed., 2005: Table 11-10). Most of these are from Titus phase sites in the eastern part of the Big Cypress Creek basin.

The last vessel is a compound form (see Figure 11b) from Burial III. This small grog-tempered and engraved vessel has two conjoined parts, an upper carinated bowl form joined to a lower bottle form. The upper vessel portion has a Simms Engraved decorative motif while the lower bottle portion has a distinctive Hodges Engraved design on it. It is our impression that these unique forms of vessels occur in post A.D. 1600 
Caddo mortuary contexts in a limited number of sites in the eastern part of the Big Cypress Creek basin (Mitchell 2000:34; Perttula 2006c:14; Perttula and Nelson 2004).

\section{Elbow Pipe}

A well-made elbow pipe was placed in the northeastern end of the Burial III pit, in what was likely to have been the head area of the deceased (see Davis and Golden 1960: Figure 9). This elbow pipe is tempered with finely-crushed grog, and decorated on both the bowl and stem with engraved motifs (Figure 13a-b). On the pipe bowl, the decorative motif consists of alternating small triangular and circular elements separated by tick marks (Figure 13a); white kaolin clay pigment has been rubbed in the design. The pipe stem has sets of rectilinear engraved lines repeated twice on one side of the stem (Figure 13b).

Figure 13. Elbow pipe from Burial III: a, looking down on the pipe bowl; b, looking sideways at the pipe stem and bowl.

The elbow pipe is $68.0 \mathrm{~mm}$ in length, with a bowl height of $20.5 \mathrm{~mm}$; the pipe walls are $4.9 \mathrm{~mm}$ thick. The bowl has a maximum orifice diameter of $43.2 \mathrm{~mm}$, compared to an exterior orifice diameter on the stem of $27.0 \mathrm{~mm}$. The diameter of the bored hole connecting the bowl to the stem is $6.8 \mathrm{~mm}$.

\section{Kaolin Clay Masses}

There were three kaolin clay masses (ca. $108 \mathrm{~g}$ ) in Burial II, near what was likely the head of the deceased (Davis and Golden 1960: Figure 7). These offerings may have been sources of clay intended for vessel manufacture or to be ground up for use as a clay pigment.

\section{Ground Stone Tools}

There are two polished celts among the listed unassociated funerary objects from the Ben McKinney site. The first, made of either diorite or tuff found in the Ouachita Mountains of southeastern Oklahoma, has a flat poll end and a $33.2 \mathrm{~mm}$ wide bifacial bit (Figure 14a); this was found amidst the "line of artifacts" that likely represents the offerings placed in an undefined Caddo burial or burials (Davis and Golden 1960:27 and Figure 4). The second celt, an offering in Burial III, was made of a non-local graywacke (Figure 14b). It has a rounded poll end and a $34.6 \mathrm{~mm}$ wide bit (Table 5).

Figure 14. Celts from burials at the Ben McKinney site: a, line of artifacts; b, Burial III. 
Table 5. Celts from the Ben McKinney site.

\begin{tabular}{lllllll}
\hline $\begin{array}{l}\text { No. } \\
\text { Length } \\
(\mathrm{mm})\end{array}$ & $\begin{array}{l}\text { Width } \\
(\mathrm{mm})\end{array}$ & $\begin{array}{l}\text { Thickness } \\
(\mathrm{mm})\end{array}$ & $\begin{array}{l}\text { Bit width } \\
(\mathrm{mm})\end{array}$ & $\begin{array}{l}\text { Bit length } \\
(\mathrm{mm})\end{array}$ & Raw material \\
\hline 92 & 72.8 & 31.2 & 25.8 & 34.6 & 17.0 & graywacke \\
94 & 71.0 & 33.1 & 26.0 & 33.2 & 20.5 & diorite or tuff \\
\hline
\end{tabular}

Other ground stone tools include two ferruginous sandstone pitted stones, one near the "line of artifacts" described by Davis and Golden (1960:27) (F141 on Figure 8), and the other (F126 on Figure 8) northeast of the "line of artifacts." One of these has only a single battered pit, but the other tool has three pits, one on each side of the ferruginous sandstone cobble.

\section{Arrow points}

There are six Talco arrow points in the Ben McKinney site collection: one from Burial I and five from Burial III. Half of the Talco points are made from non-local Red River gravel cherts, another two from non-local novaculite (also to be found in the Red River gravels), and the last one is on a non-local greenish-gray Ouachita Mountains quartzite. It may be the case that all six Talco points from the site are made on lithic raw materials whose ultimate source was the Ouachita Mountains of southeastern Oklahoma (see Banks 1990).

The Talco point in Burial I was found near what would have been the left leg of the deceased (see Davis and Golden 1960: Figure 5). This point was made from a nonlocal gray, lustrous chert, and has resharpened and serrated blades (Figure 15f and Table $6)$.

Figure 15. Talco arrow points from Burials I and III at the Ben McKinney site: a-e, Burial III; f, Burial I.

Table 6. Talco points from the Ben McKinney site.

\begin{tabular}{|c|c|c|c|c|c|c|c|}
\hline Burial & No. & $\begin{array}{l}\text { Length } \\
(\mathrm{mm})\end{array}$ & $\begin{array}{l}\text { Width } \\
(\mathrm{mm})\end{array}$ & $\begin{array}{l}\text { Thickness } \\
(\mathrm{mm})\end{array}$ & $\mathrm{RS} / \mathrm{S}^{*}$ & chipping & Raw material \\
\hline I & 91 & 41.9 & 15.8 & 2.9 & $+/+$ & bifacial & gray lustrous chert \\
\hline III & 84 & - & 14.3 & 3.3 & $-/-$ & bifacial & light gray chert \\
\hline III & 85 & - & 12.2 & 2.6 & $-/-$ & bifacial & dark gray Woodford chert \\
\hline III & 86 & 31.1 & 14.0 & 2.6 & $+/-$ & bifacial & gray quartzite \\
\hline III & 87 & 37.1 & 14.0 & 3.0 & $-/+$ & bifacial & grayish-brown novaculite \\
\hline III & 90 & 36.3 & 14.2 & 2.8 & $-/+$ & bifacial & gray novaculite \\
\hline
\end{tabular}

*RS/S=resharpened/serrated; +=presence; -=absence 
Only one of the five Talco points from Burial III were found in situ within the burial (no. 90, see Table 6). It was found on the floor of the burial pit, near Vessel 58 and what would have been the right leg of the deceased (Davis and Golden 1960:24 and Figure 9). The other four came from the deeper part of the burial pit, at least one also being found near Vessel 58. These five Talco points probably were part of a single quiver of arrow points, probably knapped by one individual based on the flaking of each of the points, placed in the burial pit. The quiver apparently became scattered between the time of their interment with the individual and their archeological recovery.

\section{Dart Point}

A single Yarbrough dart point is in the collection, but it was not found in an apparent funerary context. The point, made and used in the Late Archaic period (ca. 2500-500 B.C.), is on a local coarse-grained quartzite. The discovery of this dart point suggests that the Ben McKinney site burial area was used to a limited extent well before the Titus phase interment of burials.

\section{Biface}

An ovate biface preform of fine-grained quartzite was found in the fill of Burial I (Davis and Golden 1960:16), within $50 \mathrm{~cm}$ of the southwestern end of the burial pit. It is $57.9 \times 33.0 \times 12.2 \mathrm{~mm}$ in length, width, and thickness, and is most likely a discarded preform originally intended for dart point manufacture. Because it came from the fill of the burial pit, the preform is not clearly associated with the other funerary objects found with this burial, and may be further evidence of a Late Archaic use of the burial area.

A second biface was recovered in the lower part of Burial III (Davis and Golden 1960:24 and Figure 9), about $15 \mathrm{~cm}$ above the burial pit floor and near Vessel 69. This biface is made from a non-local brownish-gray chert (Figure 16), and had been knapped by a soft hammer after the cortex had been removed; the bifacial edges of the piece were not final shaped before the biface was discarded or placed in the burial pit; the biface is $35.9 \times 29.0 \times 9.1 \mathrm{~mm}$ in thickness.

Figure 16. Biface from Burial III at the Ben McKinney site.

\section{Pleasure Point Site (41MR63)}

The Pleasure Point site is a large (ca. 120-140 burials) Titus phase community cemetery that has been heavily looted over the years (Gadus and Fields 1996; Perttula et al. 1996; TARL and COE records). There are 12 whole ceramic vessels from the Pleasure Point site in the COE NAGPRA collections from Lake O' the Pines. These vessels were confiscated by the COE from a local collector who had been working at the site, but their provenience or context within the site or within specific burials is not known.

Gadus and Fields (1996) previously documented the collection in detail, and we chose not to duplicate their effort as part of this project. We examined each of the vessels 
in detail, supplementing and/or amending particular attributes (temper and decoration) of several of the vessels (Table 7) and then we photographed each of the vessels.

Table 7. Vessels from the Pleasure Point Site.

\begin{tabular}{|c|c|c|c|c|c|c|}
\hline Vessel No. & Temper & $\begin{array}{l}\text { Height } \\
(\mathrm{cm})\end{array}$ & $\begin{array}{l}\text { Orifice Diameter } \\
(\mathrm{cm})\end{array}$ & $\begin{array}{l}\text { Volume } \\
\text { (liters) }\end{array}$ & Decoration & Type \\
\hline \multicolumn{7}{|l|}{ Jar } \\
\hline 1 & grog & 14.7 & 13.8 & 1.4 & punctated-appliqued & $\begin{array}{l}\text { possible } \\
\text { Mockingbird } \\
\text { Punctated }\end{array}$ \\
\hline 3 & $\begin{array}{l}\text { grog- } \\
\text { bone }\end{array}$ & 12.3 & 12.0 & 0.7 & $\begin{array}{l}\text { plain, } 2 \text { suspension } \\
\text { holes }\end{array}$ & unknown \\
\hline 4 & grog & 14.9 & 13.0 & 0.95 & tool punctated-incised & $\begin{array}{l}\text { Maydelle } \\
\text { Incised }\end{array}$ \\
\hline 5 & grog & 32.3 & 28.8 & 12.1 & $\begin{array}{l}\text { neck banded and } \\
\text { brushed }\end{array}$ & $\begin{array}{l}\text { La Rue } \\
\text { Neck Banded }\end{array}$ \\
\hline 6 & $\begin{array}{l}\text { grog- } \\
\text { bone }\end{array}$ & 15.9 & 16.5 & 1.75 & $\begin{array}{l}\text { appliqued, incised, } \\
\text { punctated }\end{array}$ & $\begin{array}{l}\text { Harleton } \\
\text { Appliqued }\end{array}$ \\
\hline 7 & grog & 24.3 & 21.2 & 6.4 & brushed-combed & Unknown \\
\hline \multicolumn{7}{|c|}{ Carinated Bowl } \\
\hline 2 & shell & 11.1 & 24.5 & 2.7 & engraved scroll & $\begin{array}{l}\text { unidentified, } \\
\text { trade vessel }\end{array}$ \\
\hline 8 & grog & 15.8 & 27.5 & 4.5 & $\begin{array}{l}\text { interlocking engraved } \\
\text { scroll }\end{array}$ & Ripley Engraved \\
\hline 9 & grog & 11.0 & 21.4 & 2.2 & pendant triangle motif & Ripley Engraved \\
\hline \multicolumn{7}{|l|}{ Bottle } \\
\hline 10 & grog & 15.6 & 4.9 & 0.6 & engraved scroll & Wilder Engraved \\
\hline 11 & grog & 13.1 & 4.9 & 0.2 & engraved chevrons & unknown \\
\hline 12 & grog & N/A & N/A & N/A & engraved scroll & unknown \\
\hline
\end{tabular}

\section{Vessels}

The 12 vessels include six jars (Figure 17a-d), three carinated bowls (Figure 18ac), and three bottles (Figure 19a-b). Given the mean number of ceramic vessels found in Titus phase burials in this stretch of Big Cypress Creek, these 12 vessels could be from a single adult individual, but certainly no more than two adults (cf. Perttula 2005, ed.:

Table 11-6).

Figure 17. Jars from the Pleasure Point site: a, Vessel 1; b, Vessel 4; c, Vessel 5; d, Vessel 6; e, Vessel 7.

Figure 18. Carinated bowls from the Pleasure Point site: a, Vessel 2; b, Vessel 8; c, Vessel 9. 
Figure 19. Bottles from the Pleasure Point site: a, Vessel 10; b, Vessel 11.

More than 91 percent of the Pleasure Point vessels are tempered with grog, and one engraved carinated bowl has shell temper. The use of shell temper in this vessel suggests that it is a trade vessel, since shell was not a temper of choice for Titus phase Caddo potters. Instead, this vessel likely was obtained from a Caddo group living on the Red River - in the area of the confluence of the Kiamichi and Red rivers in Red River County, Texas - well to the north of the Pleasure Point site. Almost 17 percent of the vessels also had burned bone added to the vessel paste as a temper (see Table 7). The jars are both medium-sized and large (including one very large La Rue Neck Banded jar (Figure 17c) that had a volume of 12.1 liters; all three of the carinated bowls are large; and the bottles are small to medium-sized (0.2-0.6 liters).

\section{Jonas Short Site (41SA101)}

The Jonas Short site was excavated by a RBS archeological team in 1956 prior to the construction of Lake Sam Rayburn (Jelks 1965:22-52; see also McClurkan et al. 1980; Story 1990:280, 282). The funerary objects of concern (and still present in the TARL collections) in this study came from excavations in a small earthen mound (Figure 20), about $29 \mathrm{~m}$ in diameter and $2.4 \mathrm{~m}$ in height, and include objects in a cremation (Burial 2) under the center of the mound and five caches of artifacts in the southwestern quadrant of the mound excavations, but in Zone A or Zone B mound fill.

Figure 20. Excavation area in the mound at the Jonas Short site.

Although no radiocarbon dates have been obtained from the Jonas Short mound excavations, there is no question that it was constructed by Woodland period groups of the Mossy Grove Culture that lived in the Neches-Angelina river valleys (Story 1990:Figure 39). On the basis of comparisons with other Woodland period mounds in the Red River valley of Arkansas and Louisiana, Schambach (2002:111) suggests that the Jonas Short mound was built and used as early as ca. 200 B.C. and no later than A.D. 300. During this period of time, Woodland peoples first built mounds over central pits containing cremated human bone, as well as "small additional deposits of prestige goods that had been laid on intermediate surfaces, probably along with fragmentary human remains, and covered with soil as the mounds were built." After ca. A.D. 100, building mounds over central cremations by Woodland peoples apparently ceased, but caches of prestige artifacts (vessels and copper ornaments), cremated human remains, and parts of uncremated remains were incorporated into the mounds as they were built up (Schambach 2002:111).

The cremation (Burial 2) contained at least two individuals (based on human teeth from different individuals) that were burned in situ, in an $0.6 \times 1.8 \mathrm{~m}$ area of burned human bone, charcoal, and other burned organic materials (Jelks 1965:30). The only funerary objects found with this burial were two copper bracelets. Apparently immediately after the cremation event, the burial feature was covered by a light gray sand 
mound fill (Zone A) about $1.8 \mathrm{~m}$ in thickness. Story (1990:280) suggests that "the death of one or both of the cremated individuals appear to have been the event that triggered the building of the mound." After the deposition of Zone A mound fill, the mound was capped with a zone of compact, reddish sandy clay (Zone B).

The caches of artifacts were placed in the mound fill as the mound was being constructed, and there was no evidence recorded during the excavations that suggests these caches were placed in pits (Jelks 1965:35, 43; Story 1990:280). Only a single human skull fragment was found in one of the caches (Cache 2), but in the case of the other four caches, the "possibility that they had completely decomposed, leaving no traces, cannot be discounted" (Story 1990:280).

Cache 1 (in Zone B) had a boat stone made from a non-local igneous raw material, a quartz pendant (Jelks 1965:Figure 14b), and nine quartz crystals. There were a number of small stream-rolled quartz pebbles inside the boat stone concavity. Jelks (1965:37) suggests that the quartz pendant and the quartz crystals were "part of a single necklace or similar ornament."

Cache 2 (in Zone B) had a number of unique offerings. Amongst them were a large oval biface from non-local chert, a well-made Gary point (Jelks 1965:Figure 17h) of petrified wood, four large stemmed dart points, a reels-shaped copper gorget, at least 11 perforated elk teeth, and a small piece of a probable human skull. The copper gorget and elk teeth were apparently strung on a necklace, perhaps along with two of the large stemmed dart points, based on their position in the cache (Jelks 1965:40).

Cache 3 was found in the upper part of the Zone A mound fill. This cache also had a hornblende syenite boat stone (see Jelks 1965: Figure 13d), petrified wood knife fragments, a concentration of stone chips, and a few pieces of unidentifiable bone (Jelks 1965:42).

Cache 4 covered an area $0.4 \times 0.2 \mathrm{~cm}$ in size in the upper part of Zone A. Found in it were "a small heap of waterworn pebbles", lithic debris, and one petrified wood Kent dart point (Jelks 1965:43 and Figure 13e).

The last cache, Cache 5, was also encountered in the upper part of Zone A in the mound. Artifacts included in the cache covered a $1.8 \mathrm{~m}$ area, and included 61 small stream-worn pebbles, eight petrified wood chips, a quartz crystal with a grooved end, and two Kent dart points made of petrified wood (Jelks 1965:44 and Figure 13f-g).

\section{Copper Bracelets}

One of the five copper bracelets recovered in the Burial 2 (Feature 10) cremation was not documented during the course of this project because it is on loan to the COE Lake Sam Rayburn project office (Laura Nightengale, February 7, 2007, e-mail communication to the authors). The other four (part of a multiple bracelet elements stacked one atop another) are also from Burial 2, the pre-mound cremation that was 
buried by mound fill (Figure 21 and Table 8 ). These bracelets are the sole funerary offerings from Burial 2.

Figure 21. Copper bracelets from Burial 2 at the Jonas Short site: a, c-d, elements of the second bracelet; $b$, first bracelet.

Table 8. Copper Bracelets from the Jonas Short site.

\begin{tabular}{llcl}
\hline $\begin{array}{l}\text { Diameter } \\
(\mathrm{mm})\end{array}$ & $\begin{array}{l}\text { Bracelet opening } \\
(\mathrm{mm})\end{array}$ & $\begin{array}{c}\text { width of the bracelet band } \\
(\mathrm{mm})\end{array}$ & $\begin{array}{l}\text { Thickness } \\
(\mathrm{mm})\end{array}$ \\
\hline 69.0 & 5.0 & 3.7 & 3.6 \\
70.0 & 5.0 & 4.1 & 3.9 \\
63.0 & 9.0 & 3.4 & 1.9 \\
36.0 & $39.0 *$ & 11.0 & 2.4 \\
\hline
\end{tabular}

*as originally measured by Jelks (1965:31), the gap between the two ends of the bracelet was $16.0 \mathrm{~mm}$

The bracelets were made from strips or bars of copper between 1.9-3.9 mm thick that were bent into a rough circular shape. They each have relatively small gaps between the two ends of each bracelet. The compound bracelet (see Figure 21a, c-d) "consists of four separate elements - each made of a copper bar that is square to subrectangular in cross section - stacked on top of one another. The bars were bent into individual bracelets..." (Jelks 1965:31).

\section{Thin Hammered Copper Fragments}

There are several miscellaneous small fragments of thin hammered sheet copper from Cache 2 (Figure 22). These small pieces are apparently all that are left of the reelshaped copper gorget (Jelks 1965: Figure 17b) found in this cache along with a large biface, a Gary point, four large stemmed dart points, and perforated elk teeth. One of the pieces of copper has small rivets $(2.5 \mathrm{~mm}$ in diameter $)$ visible in it.

Figure 22. Fragments of thin hammered copper fragments from Cache 2 at the Jonas Short site.

\section{Perforated Elk Teeth}

The 11 perforated elk teeth (Figure 23) are also from Cache 2; they are copperstained, presumably because they came in contact with the copper gorget found in this cache. The elk teeth have 1.1-3.1 mm diameter perforations. The elk teeth are not all of the same form, suggesting that perhaps they received some modification at the time they were perforated. The smaller elk teeth (with the smaller perforations, $n=2$ ) are narrow in 
width, while another seven are rectangular in shape with larger perforations near the top of the tooth. Two other perforated elk teeth are fragmentary.

Figure 23. Perforated elk teeth from Cache 2.

\section{Large Dart Point}

The one remaining very large stemmed dart point in the COE NAGPRA collections from the Jonas Short mound excavations is also from Cache 2 (Figure 24; see Jelks 1965: Figure 17d). It was found about $0.8 \mathrm{~m}$ northeast of the copper gorget.

This point has a slightly contracting and short stem, a flat base, and downwardpointing barbs shaped by basal notching on the stem. It is $17.2 \mathrm{~cm}$ in length, a maximum of $6.15 \mathrm{~cm}$ in width, $12.8 \mathrm{~mm}$ in thickness, and has a stem width of $30.9 \mathrm{~mm}$.

Figure 24. Large dart point from Cache 2 at the Jonas Short site.

The large dart point is made on a lustrous dark grayish-brown chert of non-local origin; there is no cortex remaining on the tool. Both edges of the dart point have been serrated by careful pressure-flaking.

\section{Biface}

Also found in Cache 2 was a very large oval-shaped biface (Figure 25, see also Jelks 1965:Figure 17a) or bifacial blank. It is $16.6 \mathrm{~cm}$ in length, a maximum of $9.84 \mathrm{~cm}$ in width, and $23.0 \mathrm{~mm}$ in thickness.

This biface is made from a lustrous dark gray to a dark blackish-gray chert, and all evidence of cortex has been removed by hard hammer shaping and thinning flakes. There is evidence of platform abrading and crushing on both lateral edges of the biface, but otherwise the edges are sinuous and still sharp. The source of the chert is not known, but its size and lustrous quality indicate that it is not of local origin, because any local cherts are at best pebble-sized and have earth-toned colors.

Figure 25. Biface from Cache 2 at the Jonas Short site.

\section{Boat stone}

Cache 1 had a polished boat stone, found in two pieces, made from hornblende syenite (Jelks 1965:36 and Figure 13c-c') from the Hot Springs, Arkansas, area of the Ouachita Mountains. This specific mineral has an abundance of distinctive outcrops of igneous rocks that are not found elsewhere over a considerable area of Texas, Louisiana, and surrounding states (Rolingson and Howard 1997:34-35).

The boat stone had 21 small stream-rolled quartz pebbles that were found in the interior and hollowed out cavity of the tool (Figure 26a). These pebbles may have been 
collected from Red River gravels either well north or east (Thomas et al. 1980:208) of the Jonas Short site.

Figure 26. Cache 1 boat stone.

Two small holes (3.2 $\mathrm{mm}$ in diameter) had also been drilled through the boat stone, beginning from the exterior tool surface (Figure 26b). The boat stone is $15.3 \mathrm{~cm}$ in length, 3.4-4.3 cm in width (measured across the center and one end of the tool), and had a height of $2.61 \mathrm{~cm}$ along its crest.

\section{Quartz Crystals}

There are 10 quartz crystals in the Jonas Short NAGPRA collection, nine from Cache 1 and the other from Cache 5 (Figure 27). A quartz pendant was among the artifacts found in Cache 1 (Jelks 1965:Figure 14b), but it is not currently in the TARL collections. Such large quartz crystals or quartz pieces for making pendants would not have been available locally, but certainly could have been obtained from sources in the Ouachita Mountains of southeastern Oklahoma and southwestern Arkansas.

Figure 27. Quartz crystals from the Jonas Short mound excavations, Caches 1 and 5: a-c, e-j, Cache 1 ; d, cache 5 .

Three of the quartz crystals, all from Cache 1 (see Figure 27c, e-f), have shallow grooved or faceted tips (Table 9). Jelks (1965:37) suggests that this working of one end of the crystal was designed for their suspension on a necklace.

Table 9. Quartz crystals from the Jonas Short site.

\begin{tabular}{|c|c|c|c|c|c|}
\hline Lot No. & $\begin{array}{l}\mathrm{L} \\
(\mathrm{mm})\end{array}$ & $\begin{array}{l}\mathrm{W} \\
(\mathrm{mm})\end{array}$ & $\begin{array}{l}\mathrm{Th} \\
(\mathrm{mm})\end{array}$ & No. of Facets & Comments \\
\hline \multicolumn{6}{|c|}{ Crystals with faceted or grooved tips } \\
\hline 12 & 43.8 & 16.2 & 13.6 & six & - \\
\hline 15 & 25.0 & 11.2 & 10.2 & - & crushed facets; cloudy quartz \\
\hline 16 & 38.2 & 12.9 & 9.7 & six & clear quartz \\
\hline \multicolumn{6}{|c|}{ Crystals with unfaceted tips } \\
\hline 7 & 44.2 & 14.0 & 9.7 & $\operatorname{six}$ & clear quartz \\
\hline 8 & 60.0 & 17.9 & 14.0 & six & clear-cloudy quartz \\
\hline 13 & 62.0 & 20.2 & 19.6 & $\operatorname{six}$ & clear-cloudy quartz \\
\hline 14 & 53.2 & 13.9 & 12.9 & six & clear quartz \\
\hline 17 & 28.9 & 14.9 & 11.0 & - & $\begin{array}{l}\text { flake fragment with crushed } \\
\text { end; clear quartz }\end{array}$ \\
\hline 40 & 36.0 & 17.8 & 14.7 & six & clear quartz \\
\hline 263 & 44.3 & 13.9 & 10.7 & five & clear quartz \\
\hline
\end{tabular}


The quartz crystals have between five and six facets, and they have been streamworn. Most of the crystals are a clear quartz, but three have a cloudy or smoky appearance.

The use of quartz crystals and quartz ornaments has been attested to in prehistoric Caddo burials in a number of sites in northeastern Texas, southwestern Arkansas, and northwestern Louisiana (Perttula et al. 1998:324, 326). Their use as funerary offerings was also important in Woodland period contexts, as shown by the quartz pendant and crystals from Cache 1 and 5 at Jonas Short and the polished quartz figurine from the Coral Snake mound in northwestern Louisiana (McClurkan et al. 1966: Figure 14j, 1980:Figure 9j).

Quartz crystals and other artifacts made from quartz may have been a source of power for the Woodland period individuals or groups that possessed them (and then buried them) at the Jonas Short site, just as they were for other Southeastern U.S. Native American groups (see Hudson 1976:168, 356-357). Hudson (1976:356-357) has noted that quartz crystals were aids in hunting and in predicting the future, and "had to be handled carefully. They were hidden in a dry place until they were actually used, and they were never kept inside one's house." Emerson (1989:82) comments that because quartz crystals were considered 'underworld' objects, they gave the owners power, but a power that had to be carefully controlled by caring for the crystal: "When the owner died it [the quartz crystal] was buried with him or else it would roam free, seeking the lives of men."

\section{Walter Bell Site (41SB50)}

The Walter Bell site was also excavated by a RBS archeological team in 1957 at what became Lake Sam Rayburn (Jelks 1965:53-69). This was a small prehistoric Caddo farmstead or hamlet with two circular houses, a portion of a third house in the area of House 2, midden deposits, and six burials (Figure 28). Based on certain kinds of artifacts found at the site (i.e., elbow pipes, a high proportion of brushed utility ware sherds from Broaddus Brushed vessels, and lower proportions of Pineland Punctated-Incised vessel sherds), the Walter Bell site was apparently occupied in the Late Caddo period, after ca. A.D. 1450/1500 (Middlebrook 1994:26-29 and Figure 4, 1997; Perttula 2004:390, 395).

Four of the burials (Burials 1-3 and 6) were in close association (either inside the house and underneath the house floor) with House 1, one (Burial 4) was inside House 2, and Burial 5 was in an open area (possibly a courtyard or work area) between the two Caddo houses. Funerary objects placed with the deceased included one to six vessels per individual, Perdiz arrow points, conch shell beads, deer ulna tools and deer food offerings, mussel shells, and engraved bird bone flageolets.

Figure 28. Map of the Walter Bell site and the locations of Houses 1 and 2 and Burials 16. 
Among the reported unassociated NAGPRA items recovered from 41SB50 are a marine shell columella bead (found at the neck of the deceased, Jelks 1965:61) and a Broaddus Brushed jar from Burial 2; the jar had been placed at the right side of the skull. Burial 2 was within the walls of House 1, and was a 2-4 year old child placed in an extended position on its back, with the head at the southern end of the burial pit. The marine shell bead is missing from the collection at TARL, and the ceramic jar is at the COE Lake Sam Rayburn project office (Laura Nightengale, February 7, 2007, e-mail communication to the authors). The Broaddus Brushed jar has not been documented as part of this project, but an illustration in Jelks (1965:Figure 62b) indicates it is a small everted rim jar with horizontal brushing on the rim and vertical brushing on the vessel body.

The one NAGPRA item from 41SB50 remaining in the TARL collections is a bird bone flute or flageolet from Burial 6 (Figure 29). Burial 6 is a middle-aged adult, probably a Caddo male (Jelks 1965:65), found beneath the north wall of House 1. This individual was flexed, and was laid on its right side, with the head to the northwest. The bird bone flageolet was placed in the area of the hands, with one end extending beneath the mandible. Other bird bone flageolets were also found in Burials 3 and 5 at the Walter Bell site, and in a Late Caddo burial (Burial 2) at the Wiley Price site (41SA94), also at Lake Sam Rayburn (Jelks 1965:185-186).

Figure 29. Bird bone flageolet from Burial 6 at the Walter Bell site.

The flageolets were made from the long bones of large birds, probably a crane or turkey, and have a single stop hole near one end of the flute (see Figure 29). The flageolet from Burial 6 has a $12.3 \mathrm{~cm}$ long decorated area that begins at the stop hole; the flute is $25 \mathrm{~cm}$ in total length. The decoration consists of intersecting hatched engraved zones, and the hatched zones are approximately $12.7 \mathrm{~mm}$ in height along the body of the flute.

\section{NATIVE AMERICAN GRAVES PROTECTION AND REPATRIATION ACT (NAGPRA) FINDINGS AND RECOMMENDATIONS}

In this report, we have documented funerary objects from a number of prehistoric archeological sites (dating between ca. 200 B.C. and ca. A.D. 1600) at three U.S. Army Corps of Engineers, Fort Worth District reservoirs in northeastern Texas. These funerary objects were listed in the U.S. Army Corps of Engineers (2004:305-317) document Inventory of Human Remains, Associated Funerary Objects, and Unassociated Funerary Objects as required by Native American Graves Protection and Repatriation Act as unassociated funerary objects of unknown cultural affiliation. The archeological evidence that has been reviewed in this study, and the documentation of the funerary objects from the various sites, have led us to reach the following findings under NAGPRA: 
I. The funerary objects documented at the Knight's Bluff (41CS14), Sherwin (41CS26), Ben McKinney (41MR12), Pleasure Point (41MR63), and Walter Bell (41SB50) sites as part of this study are from prehistoric Caddo burials. It is well known from archeological, bioarcheological, historical, archival, and oral historical records that the prehistoric Caddo are ancestral to the modern-day Caddo Nation of Oklahoma. Consequently, the funerary objects from these sites are culturally affiliated with the Caddo Nation of Oklahoma as defined in 25 U.S.C. 3001, Section 2 and Code of Federal Regulations, Title 43, Part 10, Section 10.2(e).

II. The preponderance of archeological evidence supports this finding, namely (a) the manner of burial practice when that information is available (i.e., in a pit where the body of the deceased Caddo individual is primarily laid in the grave in an extended position with funerary objects placed around the body); (b) the kinds of funerary objects placed with the deceased, including culturally diagnostic and well-recognized Caddo pottery types and arrow point types, and other recognizably Caddo objects (i.e., elbow pipes and celts in the case of the Ben McKinney site and the bird bone flageolet in the case of the Walter Bell site); (c) the occurrence of the burials from these sites in direct association with either other prehistoric Caddo burials in cemeteries or in direct association with Caddo habitation features (middens and house structures); and (d) the use of Caddo style (cf. Derrick and Wilson 1997) cranial deformation in one burial from the Knight's Bluff site.

III. Because there are no human remains from U.S. Army Corps of Engineers controlled NAGPRA collections from the Ben McKinney (in this case no human remains were preserved in the burial pit, see Davis and Golden 1960) and Pleasure Point (in this case, while there are human remains in the COE NAGPRA collections from the site [Wilson and Steele 1996], none can be associated with the funerary objects discussed in this study) sites, the prehistoric Caddo funerary objects from them are considered unassociated funerary objects (25 U.S.C. 3001, Section 2 (3)(b) and Code of Federal Regulations, Title 43 Section 10.2(d)(2)(ii)).

IV. The funerary objects from Burial 4 at the Knight's Bluff site, Burials 4 and 6 at the Sherwin site, and Burials 2 and 6 at the Walter Bell site are considered to be associated funerary objects under NAGPRA (25 U.S.C. 3001, Section 2 (3)(a) and Code of Federal Regulations, Title 43 Section 10.2(d)(2)(i)). We reached this finding because of two facts: first, the archeological reports that describe the burials from these three sites state that human remains were present in the burial pits (see Jelks 1961, 1965). In several instances, the human remains in the burials are illustrated in photographs showing the completed burial excavations (see Jelks 1961:Plate 15c, 1965: Figures 23 and 25). And second, the human remains (specifically the skull) from Burial 4 at the Knight's Bluff site were sufficiently well preserved that they were removed for further study and measurements (Jelks 1961:Plate 16a-b).

V. In the case of the Snipes site at Lake Wright Patman, our finding is that the funerary objects from Burials 6-9 are culturally affiliated with the Caddo Nation of Oklahoma through their ancestral relationship with Woodland period (ca. 500 B.C-A.D. 800) 
populations in the Red and Sulphur River basins that are known as the Fourche Maline Culture. The Snipes occupation and burials are from a Fourche Maline component that date to the latter part of the Woodland period.

There is a general consensus of opinion among archeologists that specialize in Woodland and Caddo archeology and prehistory that the Fourche Maline Culture "evolved into Caddo culture" (Schambach 2002:91) around A.D. 800 or so. As Schambach (2002:108) indicates, "most archeologists interested in Caddo culture" share his opinion that the Fourche Maline Culture is ancestral to Caddo culture in northeastern Texas, southwestern Arkansas, northwestern Louisiana, and southeastern Oklahoma, the traditional Caddo homelands (Rogers and Sabo 2004: Figure 1). From comprehensive bioarcheological studies of Woodland and Caddo skeletal remains, Rose et al. (1998:115) have concluded that there is "not even a hint that the southern Caddo populations did not derive from the preceding Fourche Maline inhabitants."

VI. Because there are no human remains from U.S. Army Corps of Engineers controlled NAGPRA collections from Burials 8 and 9 at the Snipes site (in this case no human remains were apparently preserved in the burial pit, see Jelks 1961), the prehistoric funerary objects from these two burials are considered unassociated funerary objects (25 U.S.C. 3001, Section 2 (3)(b) and Code of Federal Regulations, Title 43 Section 10.2(d)(2)(ii)).

The funerary objects from Burials 6 and 7 at the Snipes site are considered to be associated funerary objects under NAGPRA (25 U.S.C. 3001, Section 2 (3)(a) and Code of Federal Regulations, Title 43 Section 10.2(d)(2)(i)). This finding is reached because the archeological report that describe these burials from the site state that human remains were present in the burial pits (see Jelks 1961). In one instance, the human remains in one of the burials (Burial 7) at the Snipes site were sufficiently well preserved that they were removed for further study and measurements (Jelks 1961:Plate 17e-f).

VII. The Jonas Short site is somewhat of a conundrum for researchers interested in Caddo archeology. In a Caddo origin myth reported by James Mooney (1896) and paraphrased here, it is suggested that the Caddo came from somewhere near the south bank of the Red River, just at its junction with the Mississippi." This place today is near Marksville State Park in Marksville, Louisiana. The Marksville site, with multiple mounds that ironically date from the same time period as the Mossy Grove culture and the Jonas Short site, is now a state park. It can be conjectured that an early tradition of mound building began there, or in the Red River and Mississippi River confluence area, and spread west to northwesterly and/or west to southwesterly into the eastern part of the state of Texas. If this were the case, we should also find sandy paste pottery and archeological sites that are contemporaneous with the Mossy Grove culture sites between Marksville and the current border of Louisiana and Texas. This is indeed the case as Mossy Grove culture archeological sites have been recorded in the area of Toledo Bend Reservoir on the Sabine River, yet few have ever been written up and reported. Although the Mossy Grove tradition of mound building has general cultural similarities to Hopewell mound building practices across the Midwest and Southeast, with the Caddo's origin story in mind, that 
tradition is more likely to have originated in the area of Marksville than more far-flung regions.

The NAGPRA inventories and available information regarding the Jonas Short (and village area) as stated, provided no available bioarcheological evidence and no radiocarbon dates from either the mound or the village with which to assess the question of cultural affiliation. However, in reviewing all of the available information, we believe that the Jonas Short site is culturally affiliated to the Caddo Nation of Oklahoma. We assert that there are ancestral ties of the Caddo to the Mossy Grove culture based on geographical, folklore, historical, and relevant archeological information (i.e., the specific form of burial mound tradition).

Archeology and biology are only two of the many factors that must be taken into account when considering the matter of cultural affiliation. The cultural affiliation of the human remains and funerary objects at this site should be based on a "an overall evaluation of the totality of the circumstances and evidence pertaining to the connection between the claimant and the material being claimed and should not be precluded solely because of some gaps in the record" (Code of Federal Regulations, Title 43, Section 10.14(d)). Even though this mound may date 600 years before what would be considered Alto phase Caddo, these Alto phase Caddo are peoples from East Texas and northwest Louisiana that had cultural characteristics such as mound building and the making and giving of funerary offerings shared with the earlier archeological deposits at Jonas Short, and also had an intimate knowledge of the area that would come to be known traditionally as the Caddo homeland.

The Fort Worth District, U.S. Army Corps of Engineers, in their Section 5 NAGPRA inventories (but as such, not a part of this "culturally unidentifiable" collection), but without prior consultation, listed the Caddo Tribe as culturally affiliated to the Jonas Short site from human remains and objects (Human Remains Accession \#3058 and three Perdiz points, \#444, \#513, and \#514, missing, from Inventory of Possibly Affiliated Human Remains, Caddo Tribe - Sam Rayburn Lake page 89, and Inventory of Associated Funerary Objects- Fort Worth District page 249).

Even though the human remains and Perdiz points are likely from the Caddo village area, based on the Perdiz points, the Fort Worth District Corps of Engineers' determination states: "Geographic affiliation is consistent with the historically documented territory of the Caddo Tribe. Objects were found with human remains identified as Feature 5, possibly Burial 1 (Accession \#3058)." Even though these remains and objects are not archeologically related to the main use of the mound for the placement of burials and funerary offerings, the Caddo have asserted through geographical information, oral history, origin stories, and archeology that they were indigenous to areas of Texas, Louisiana, Oklahoma, and Arkansas, living there before other tribes moved into the area.

Cultural affiliation does not necessarily mean genetic proof or lineal descent. As stated in 43 CFR 10.14(f), the standard of proof is a "preponderance of the evidence" 
and not "scientific certainty." DNA analysis is never mentioned as a requirement in determining "cultural affiliation," yet many archeologists tend to equate DNA analysis as the "end all and be all" of determining cultural affiliation. From our reading of NAGPRA, cultural affiliation is very different than lineal descent or direct kinship.

Based on the available information, there is absolutely no other tribe that would have a stronger "cultural" affiliation to the Jonas Short site than the present Caddo Nation of Oklahoma. The Caddo Indians built mounds; were indigenous to the area; most of the items listed in the inventory have religious significance to the Caddo; and our report documents that a number of these artifacts are from the known "Caddo area," such as the quartz crystals, the boatstone, and the rounded pebbles, and are not local to the area. The use of quartz crystals and quartz ornaments has been attested to in prehistoric Caddo burials in a number of sites in northeastern Texas, southwestern Arkansas, and northwestern Louisiana. Their use as funerary offerings was also important in Woodland period contexts, as shown by the quartz pendant and crystals from Cache 1 and 5 at Jonas Short and the polished quartz figurine from the Coral Snake mound in northwestern Louisiana (McClurkan et al. 1966: Figure 14j, 1980:Figure 9j) (Perttula et al. 1998:324, 326).

Whether or not our determination of cultural affiliation is one that matches that of the Fort Worth District of the U.S. Army Corps of Engineers is at this point irrelevant. The final decision on cultural affiliation will be an administrative one made by the Fort Worth District Corps of Engineers in further consultation with the Caddo Nation.

\section{References Cited}

Banks, L. D.

1990 From Mountain Peaks to Alligator Stomachs: A Review of Lithic Sources in the Trans-Mississippi South, the Southern Plains, and Adjacent Southwest. Memoir No. 4. Oklahoma Anthropological Society, Norman.

Brown, I. W.

1998 Decorated Pottery of the Lower Mississippi Valley: A Sorting Manual. Mississippi Archaeological Association and Mississippi Department of Archives and History, Jackson.

Brown, J. A.

1996 The Spiro Ceremonial Center: The Archaeology of Arkansas Valley Caddoan Culture in Eastern Oklahoma. 2 Vols. Memoirs No. 29. Museum of Anthropology, The University of Michigan, Ann Arbor.

Cast, R., T. K. Perttula, B. Gonzalez, and B. Nelson

2006 Documentation of Caddo Ceramic Vessels from 41WD60, Wood County, Texas. Historic Preservation Program, Caddo Nation of Oklahoma, Binger, Oklahoma. 
Cliff, M. B.

1997 The Middle Caddoan Period in the Lower Sulphur River Area. Journal of Northeast Texas Archaeology 9:9-16.

Corbin, J. E.

1989 The Woodland/Caddo Transition in the Southern Caddo Area. In Festschrift in Honor of Jack Hughes, edited by D. Roper. Special Publication No. 5. Panhandle Archeological Society, Amarillo.

Davis, E. M. and B. Golden

1960 The Ben McKinney Site: A Titus Focus Site in the Ferrell's Bridge Reservoir Area, Northeastern Texas. Report submitted to the National Park Service by the Division of Research in Anthropology, The University of Texas in accordance with the provisions of Contract 14-10-333-242.

Derrick, S. and D. Wilson

1997 Cranial Modeling as an Ethnic Marker among the Prehistoric Caddo. Bulletin of the Texas Archeological Society 68:139-146.

Emerson, T. F.

1989 Water, Serpents, and the Underworld: An Exploration into Cahokian Symbolism. In The Southeastern Ceremonial Complex: Artifacts and Analysis, The Cottonlandia Conference, edited by P. Galloway, pp. 45-92. University of Nebraska Press, Lincoln.

Ferring, C. R. and T. K. Perttula

1987 Defining the Provenance of Red-Slipped Pottery from Texas and Oklahoma by Petrographic Methods. Journal of Archaeological Science 14:437-456.

Gadus, E. F. and R. C. Fields

1996 Ceramic Vessels from the Pleasure Point Site (41MR63), Marion County, Texas. Technical Report No. 22. Prewitt and Associates, Inc., Austin.

Gadus, E. F., R. C. Fields, J. K. McWilliams, J. Dockall, and M. C. Wilder

2006 National Register Testing of Seven Prehistoric Sites in the Sabine Mine's Area Q, Harrison County, Texas. Reports of Investigations No. 147. Prewitt \& Associates, Inc., Austin.

Hudson, C.

1976 The Southeastern Indians. The University of Tennessee Press, Knoxville.

Jelks, E. B.

1961 Excavations at Texarkana Reservoir, Sulphur River, Texas. River Basin Surveys Papers No. 21, Bureau of Ethnology Bulletin 179. Smithsonian Institution, Washington, D.C. 
1965 The Archeology of McGee Bend Reservoir, Texas. Ph.D. dissertation, Department of Anthropology, The University of Texas at Austin.

McClurkan, B. B., W. T. Field, and J. N. Woodall

1966 Excavations in Toledo Bend Reservoir, 1964-65. Papers of the Texas

Archeological Salvage project No. 8. Texas Archeological Salvage Project, The University of Texas at Austin.

McClurkan, B. B., E. B. Jelks, and H. P. Jensen

1980 Jonas Short and Coral Snake Mounds: A Comparison. Louisiana Archaeology 6:173-206.

Middlebrook, $\mathrm{T}$.

1994 An Update of Archaeological Investigations at the Tyson Site. Journal of Northeast Texas Archaeology 3:1-36.

1997 The Caddoan Occupation of the Attoyac and Angelina River Basins in the Middle Caddoan Period. Journal of Northeast Texas Archaeology 10:36-40.

Mitchell, S. A.

2000 Data Salvage Project: Greasy Creek Study. Report on file at the Texas Archeological Research Laboratory, The University of Texas at Austin.

Mooney, J.

1896 The Ghost Dance Religion, and the Sioux Outbreak of 1890. Fourteenth Annual Report of the Bureau of American Ethnology, 1892-1893, pt. 2. Bureau of American Ethnology, Smithsonian Institution, Washington, D.C.

Perttula, T. K.

1998 Caddo Ceramics from the Middle Caddoan Period Knight's Bluff Site (41CS14), Cass County, Texas. Caddoan Archeology 8(4):11-19.

2004 The Prehistoric and Caddoan Archeology of the Northeast Texas Pineywoods. In The Prehistory of Texas, edited by T. K. Perttula, pp. 370-407. Texas A\&M University Press, College Station.

2005 1938-1939 WPA Excavations at the Hatchel Site (41BW3) on the Red River in Bowie County, Texas. Southeastern Archaeology 24(2):180-198.

2006a A Study of the Buddy Jones Collection from Northeast Texas Caddo Sites. Special Publications No. 6. Friends of Northeast Texas Archaeology, Austin and Pittsburg.

2006b The M. W. Burks Site (41WD52), A Late Caddo Hamlet in Wood County, Texas. Journal of Northeast Texas Archaeology 23:1-27. 
2006c The Structure and Growth of a Titus Phase Community Cemetery in Titus County, Texas. Journal of Northeast Texas Archaeology 25:1-18.

2007 Kinsloe Focus Artifact Assemblages and Nadaco Caddo. Journal of the Northeast Texas Archaeological Society 26:116-119.

Perttula, T. K. (editor)

2005 Archeological Investigations at the Pilgrim's Pride Site (41CP304), a Titus Phase Community in the Big Cypress Creek Basin, Camp County, Texas. 2 Vols. Report of Investigations No. 30. Archeological \& Environmental Consultants, LLC, Austin.

Perttula, T. K. and B. Nelson, with contributions by J. P. Dering, L. Schniebs, R. L. Turner, Jr., M. Walters, and D. Wilson

2004 Archeological Investigations at the Shelby Site (41CP71) on Greasy Creek, Camp County, Texas. Special Publication No. 5. Friends of Northeast Texas Archaeology, Pittsburg and Austin.

Perttula, T. K. and D. L. Sherman

2009 Data Recovery Investigations at the Ear Spool Site (41TT653), Titus County, Texas. Document No. 070205. PBS\&J, Austin.

Perttula, T. K., B. Nelson, and M. Turner

1996 Initial Report on Archaeological Investigations at Lake O' the Pines: A U.S. Army Corps of Engineers-Owned Lake Facility in Northeast Texas. Friends of Northeast Texas Archaeology, Pittsburg and Austin.

Perttula, T. K., B. D. Skiles, and B. C. Yates

1993 The Goldsmith Site (41WD208): Investigations of the Titus Phase in the upper Sabine River Basin, Northeast Texas. Bulletin of the Texas Archeological Society 61:139-191.

Perttula, T. K., M. Tate, H. Neff, M. D. Glascock, E. Skokan, S. Mulholland, R. Rogers, and B. Nelson

1998 Analysis of the Titus Phase Mortuary Assemblage at the Mockingbird or “Kahbakayammaahin” Site (41TT550). Document No. 970849. Espey, Huston \& Associates, Inc., Austin.

Rice, P. M.

1987 Pottery Analysis: A Sourcebook. University of Chicago Press, Chicago.

Rogers, J. D. and G. Sabo III

2004 Caddo. In Southeast, Volume 14 of the Handbook of North American Indians, edited by R. D. Fogelson, pp. 616-631. Smithsonian Institution, Washington, D.C. 
Rogers, R., M. B. Cliff, T. K. Perttula, G. Rutenberg, S. Victor, P. Dering, and M. Malainey

2003 Excavations at the Alex Justiss Site (41TT13), Titus County, Texas. Document No. 030089, PBS\&J, and Archeological Studies Program Report No. 36, Texas Department of Transportation, Austin.

Rolingson, M. A. and J. M. Howard

1997 Igneous Lithics of Central Arkansas: Identification, Sources, and Artifact Distribution. Southeastern Archaeology 16(1):33-50.

Rose, J. C., M. P. Hoffman, B. A. Burnett, A. M. Harmon, and J. E. Barnes 1998 Skeletal Biology of the Prehistoric Caddo. In The Native History of the Caddo: Their Place in Southeastern Archeology and Ethnohistory, edited by T. K. Perttula and J. E. Bruseth, pp. 113-126. Studies in Archeology 30. Texas Archeological Research Laboratory, The University of Texas at Austin.

Schambach, F. F.

1998 Pre-Caddoan Cultures in the Trans-Mississippi South: A Beginning Sequence. Research Series No. 53. Arkansas Archeological Survey, Fayetteville.

2002 Fourche Maline: A Woodland Period Culture of the Trans-Mississippi South. In The Woodland Southeast, edited by D. G. Anderson and R. C. Mainfort, Jr., pp. 91-112. University of Alabama Press, Tuscaloosa.

Skibo, J. M.

1992 Pottery Function: A Use-Alteration Perspective. Plenum Press, New York.

Story, D. A.

1990 Cultural History of the Native Americans. In The Archeology and Bioarcheology of the Gulf Coastal Plain, by D. A. Story, J. A. Guy, B. A. Burnett, M. D. Freeman, J. C. Rose, D. G. Steele, B. W. Olive, and K. J. Reinhard, pp. 163-366. 2 Vols. Research Series No. 38. Arkansas Archeological Survey, Fayetteville.

2000 Introduction. In The George C. Davis Site, Cherokee County, Texas, by H. P. Newell and A. D. Krieger, pp. 1-31. $2^{\text {nd }}$ Edition. Society for American Archaeology, Washington, D.C.

Suhm, D. A. and E. B. Jelks (editor)

1962 Handbook of Texas Archeology: Type Descriptions. Special Publication No. 1, Texas Archeological Society, and Bulletin No. 4, Texas Memorial Museum, Austin.

Teltser, P. A.

1993 An Analytic Strategy for Studying Assemblage-Scale Ceramic Variation: A Case Study from Southeast Missouri. American Antiquity 58(3):530-543. 
Thomas, P. M., Jr., L. J. Campbell, and S. R. Ahler

1980 The Hanna Site: An Alto Village in Red River Parish. Louisiana Archaeology 5:1-381.

Thurmond, J. P.

1990 Archeology of the Cypress Creek Drainage Basin, Northeastern Texas and Northwestern Louisiana. Studies in Archeology No. 5. Texas Archeological Research Laboratory, The University of Texas at Austin.

Turner, R. L.

1978 The Tuck Carpenter Site and its Relation to other sites within the Titus Focus. Bulletin of the Texas Archeological Society 49:1-110.

1992 Prehistoric Mortuary Remains at the Tuck Carpenter Site, Camp County, Texas. Studies in Archeology No. 10. Texas Archeological Research Laboratory, The University of Texas at Austin.

Turner, R. L. and J. E. Smith, II, with contributions by T. K. Perttula, B. Nelson, M. Walters, and B. Gonzalez

2002 The Harold Williams Site (41CP10) and the Texas Archeological Society Field School of 1967. Bulletin of the Texas Archeological Society 73:1-68.

Turpin, S., J. Rabinowitz, J. Henderson, and P. E. Patterson

1976 A Statistical Examination of Caddoan Vessel Design and Shape from the Ben McKinney Site, Marion County, Texas. Plains Anthropologist 21:165-179.

U.S. Army Corps of Engineers, Fort Worth District

2004 Inventory of Human Remains, Associated Funerary Objects, and Unassociated Funerary Objects as required by Native American Graves Protection and Repatriation Act. Revised September 2004. U.S. Army Corps of Engineers, Fort Worth District, Fort Worth, Texas.

Wilson, D. and D. G. Steele

1996 Prehistoric Human Remains from 12 Sites at U.S. Army Corps of Engineers Reservoirs in Bell, Delta, Denton, Ellis, Hill, Marion, and Navarro Counties, Texas. Technical Reports No. 23. Prewitt \& Associates, Inc., Austin. 


\section{Appendix 1, Vessel Recordation Forms, 41CS8}

SITE NO.:41CS8

FEATURE: Burial 6

VESSEL NO.: 2

NON-PLASTICS: grog

VESSEL FORM: barrel-shaped bowl with a direct rim and a flat lip

CORE COLOR: not apparent

WALL THICKNESS: $3.3 \mathrm{~mm}$ near rim

INTERIOR SURFACE TREATMENT: smoothed

EXTERIOR SURFACE TREATMENT: burnished

HEIGHT: $19.0 \mathrm{~cm}$

ORIFICE DIAMETER: $14.0 \mathrm{~cm}$

DIAMETER AT BOTTOM OF RIM OR NECK: N/A

BASE DIAMETER: $12.8 \mathrm{~cm}$

ESTIMATED VOLUME: 2.1 liters

DECORATION: single horizontal over-hanging incised line on the upper part of the vessel and a single incised line on the lip itself (Figure 30a-b).

TYPE: Coles Creek Incised, var. Stoner (cf. Brown 1998:8, 53), estimated to date from ca. A.D. 550-700.

Figure 30. Coles Creek Incised, var. Stoner vessel from the Snipes site: a, side view; b, looking down at the incised lip line.

SITE NO.: 41CS8

FEATURE: Burial 7

VESSEL NO.: 3 
NON-PLASTICS: grog

VESSEL FORM: small bowl with an inverted rim and a rounded lip (Figure 31)

CORE COLOR: $\mathrm{B}$, or indicative of firing in a reducing environment

WALL THICKNESS: $3.8 \mathrm{~mm}$

INTERIOR SURFACE TREATMENT: none

EXTERIOR SURFACE TREATMENT: smoothed, but heavily pitted

HEIGHT: $6.1 \mathrm{~cm}$

ORIFICE DIAMETER: $9.4 \mathrm{~cm}$

DIAMETER AT BOTTOM OF RIM OR NECK: N/A

BASE DIAMETER: $6.5 \mathrm{~cm}$

ESTIMATED VOLUME: 0.25 liters

DECORATION: Plain

TYPE: Unidentified; Story (1990) suggests it is a Williams Plain vessel

Figure 31. Burial 7 vessel from the Snipes site.

SITE NO.: 41CS8

FEATURE: Burial 8

VESSEL NO.: 4

NON-PLASTICS: grog

VESSEL FORM: small bowl with a direct rim and a flat lip (Figure 32)

CORE COLOR: B (fired in a reducing environment)

WALL THICKNESS: $4.0 \mathrm{~mm}$

INTERIOR SURFACE TREATMENT: smoothed 
EXTERIOR SURFACE TREATMENT: none

HEIGHT: $3.3 \mathrm{~cm}$

ORIFICE DIAMETER: $9.8 \mathrm{~cm}$

DIAMETER AT BOTTOM OF RIM OR NECK: N/A

BASE DIAMETER: $6.1 \mathrm{~cm}$

ESTIMATED VOLUME: 0.12 liters

DECORATION: Plain; Story (1990) suggests it is a Williams Plain vessel

TYPE: Unidentified

Figure 32. Burial 8 vessel from the Snipes site.

SITE NO.: 41CS8

FEATURE: Burial 9

VESSEL NO.: 5

NON-PLASTICS: grog

VESSEL FORM: small bowl with an everted rim and a flat, exterior folded, lip (Figure 33)

CORE COLOR: B (fired in a reducing environment)

WALL THICKNESS: $4.1 \mathrm{~mm}$

INTERIOR SURFACE TREATMENT: smoothed

EXTERIOR SURFACE TREATMENT: smoothed

HEIGHT: $4.3 \mathrm{~cm}$

ORIFICE DIAMETER: $6.5 \mathrm{~cm}$

DIAMETER AT BOTTOM OF RIM OR NECK: N/A 
BASE DIAMETER: $5.8 \mathrm{~cm}$

ESTIMATED VOLUME: 0.12 liters

DECORATION: Plain; Story (1990) suggests it is a Williams Plain vessel

TYPE: Unidentified

Figure 33. Burial 9 plain vessel from the Snipes site. 


\section{Appendix 2, Vessel Recordation Forms, 41CS14}

SITE NO.: 41CS14

FEATURE: Burial 4

VESSEL NO.: 6995

NON-PLASTICS: grog

VESSEL FORM: Jar with a slightly everted rim and a rounded lip

CORE COLOR: Undetermined

WALL THICKNESS: $6.0 \mathrm{~mm}$

INTERIOR SURFACE TREATMENT: smoothed

EXTERIOR SURFACE TREATMENT: none

HEIGHT: $18.3 \mathrm{~cm}$

ORIFICE DIAMETER: $12.7 \mathrm{~cm}$

DIAMETER AT BOTTOM OF RIM OR NECK: $11.7 \mathrm{~cm}$

BASE DIAMETER: $9.5 \mathrm{~cm}$

ESTIMATED VOLUME: 2.1 liters

DECORATION: Opposed incised lines on the vessel rim and six panels of vertical incised lines on the vessel body that extend on the body to near the base (Figure 34a-b). Each panel is separated by a vertical appliqued fillet.

TYPE: Pease Brushed-Incised

Figure 34. Pease Brushed-Incised vessel from Burial 4 at the Knight's Bluff site: a, photograph; b, drawing by Bobby Gonzalez.

SITE NO.: 41CS14

FEATURE: Burial 4

VESSEL NO.: 6996 
NON-PLASTICS: grog

VESSEL FORM: Bowl with a direct rim, and an exterior folded and flat lip

CORE COLOR: $\mathrm{G}$ (fired in a reducing environment, but cooled in the open air)

WALL THICKNESS: $4.0 \mathrm{~mm}$

INTERIOR SURFACE TREATMENT: smoothed

EXTERIOR SURFACE TREATMENT: smoothed; organic residue near the base of the vessel

HEIGHT: $9.0 \mathrm{~cm}$

ORIFICE DIAMETER: $10.2 \mathrm{~cm}$

DIAMETER AT BOTTOM OF RIM OR NECK: N/A

BASE DIAMETER: $7.9 \mathrm{~cm}$

ESTIMATED VOLUME: 0.7 liters

DECORATION: vertically brushed on the body, with a single row of tool punctates at or just above the rim-body juncture. The rim has horizontal brushing marks (Figure 35).

TYPE: undetermined brushed-punctated utility ware

Figure 35. Brushed-punctated vessel from Burial 4 at the Knight's Bluff site.

SITE NO.: 41CS14

FEATURE: Burial 4

VESSEL NO.: 6997

NON-PLASTICS: grog

VESSEL FORM: Bottle with a direct rim and a flat lip

CORE COLOR: $\mathrm{H}$ (fired in a reducing environment, but cooled in the open air)

WALL THICKNESS: $4.0 \mathrm{~mm}$ at the neck 
INTERIOR SURFACE TREATMENT: none

EXTERIOR SURFACE TREATMENT: burnished

HEIGHT: $12.7 \mathrm{~cm}$

ORIFICE DIAMETER: $3.3 \mathrm{~cm}$

DIAMETER AT BOTTOM OF RIM OR NECK: $4.8 \mathrm{~cm}$ (on the vessel body)

BASE DIAMETER: $5.5 \mathrm{~cm}$

ESTIMATED VOLUME: 0.28 liters

DECORATION: Engraved on the bottle body, and the bottle neck is plain. There are three engraved panels defined by either hatched ladders or cross-hatched zones and crosshatched pendant triangles. Within each panel is a circle motif, one of which also has a series of attached curvilinear lines that extend from the circle to one of the panel dividers (Figure 36).

TYPE: Antioch Engraved (Jelks 1961:29)

Figure 36. Antioch Engraved bottle from the Knight's Bluff site, Burial 4. 


\section{Appendix 3, Vessel Recordation Forms, 41CS26}

SITE NO.: 41CS26

FEATURE: Burial 4

VESSEL NO.: 2041

NON-PLASTICS: grog and bone

VESSEL FORM: Small carinated bowl with an everted rim and a rounded lip (Figure 37)

CORE COLOR: E (incompletely oxidized during firing)

WALL THICKNESS: $4.0 \mathrm{~mm}$

INTERIOR SURFACE TREATMENT: smoothed

EXTERIOR SURFACE TREATMENT: smoothed

HEIGHT: $5.6 \mathrm{~cm}$

ORIFICE DIAMETER: $8.1 \mathrm{~cm}$

DIAMETER AT BOTTOM OF RIM OR NECK: $8.3 \mathrm{~cm}$

BASE DIAMETER: $5.6 \mathrm{~cm}$

ESTIMATED VOLUME: 0.21 liters

DECORATION: Plain

TYPE: Unidentified

Figure 37. Burial 4 plain vessel from the Sherwin site.

SITE NO.: 41CS26

FEATURE: Burial 4

VESSEL NO.: 2042

NON-PLASTICS: undetermined 
VESSEL FORM: Barrel-shaped Jar with a direct rim and a flat lip

CORE COLOR: Undetermined

WALL THICKNESS: $5.0 \mathrm{~mm}$

INTERIOR SURFACE TREATMENT: smoothed

EXTERIOR SURFACE TREATMENT: none

HEIGHT: $8.3 \mathrm{~cm}$

ORIFICE DIAMETER: $6.6 \mathrm{~cm}$

DIAMETER AT BOTTOM OF RIM OR NECK: $7.6 \mathrm{~cm} ; 8.3 \mathrm{~cm}$ below the rim-body juncture

BASE DIAMETER: $6.6 \mathrm{~cm}$

ESTIMATED VOLUME: 0.33 liters

DECORATION: Punctated, with rows of punctates below the lip and immediately above the rim-body juncture, with randomly placed punctates across the rim; the body is plain (Figure 38).

TYPE: Undetermined

Figure 38. Punctated jar from Burial 4 at the Sherwin site.

SITE NO.: 41CS26

FEATURE: Burial 4

VESSEL NO.: 2043

NON-PLASTICS: grog and bone

VESSEL FORM: Jar with an everted rim and a rounded lip

CORE COLOR: B (fired in a reducing environment)

WALL THICKNESS: $6.0 \mathrm{~mm}$

INTERIOR SURFACE TREATMENT: smoothed 


\section{EXTERIOR SURFACE TREATMENT: none}

HEIGHT: $7.7 \mathrm{~cm}$

ORIFICE DIAMETER: $7.7 \mathrm{~cm}$

DIAMETER AT BOTTOM OF RIM OR NECK: $7.4 \mathrm{~cm}$

BASE DIAMETER: $7.1 \mathrm{~cm}$

ESTIMATED VOLUME: 0.37 liters

DECORATION: There are two rows of tool punctates just above and below the rim-body juncture, with a thin horizontal incised line between them, and six separate panels defined by appliqued fillets on the vessel body. Within each panel are large X-shaped incised elements (Figure 39).

TYPE: a variety of Pease Brushed-Incised

Figure 39. Pease Brushed-Incised jar from Burial 4 at the Sherwin site.

SITE NO.: 41CS26

FEATURE: Burial 6

VESSEL NO.: 2045

NON-PLASTICS: grog and bone

VESSEL FORM: Jar with a short everted rim and a rounded lip

CORE COLOR: F (fired in a reducing environment and cooled in the open air)

WALL THICKNESS: $3.5 \mathrm{~mm}$ at the rim

INTERIOR SURFACE TREATMENT: smoothed

EXTERIOR SURFACE TREATMENT: smoothed

HEIGHT: $11.7 \mathrm{~cm}$

ORIFICE DIAMETER: $8.7 \mathrm{~cm}$

DIAMETER AT BOTTOM OF RIM OR NECK: $10.0 \mathrm{~cm}$ 
BASE DIAMETER: $6.1 \mathrm{~cm}$

ESTIMATED VOLUME: 0.6 liters

DECORATION: Horizontal neck banded coils on the rim and two rows of punctates just below the rim-body juncture (Figure 40).

TYPE: grog-tempered variety of Nash Neck Banded

Figure 40. Nash Neck Banded jar from Burial 6 at the Sherwin site.

SITE NO.: 41CS26

FEATURE: Burial 6

VESSEL NO.: 2046

NON-PLASTICS: grog

VESSEL FORM: Jar with everted rim and a rounded lip; two strap handles are attached to the rim, with two rim peaks (Figure 41)

CORE COLOR: Undetermined

WALL THICKNESS: $4.0 \mathrm{~mm}$ at the rim

INTERIOR SURFACE TREATMENT: smoothed

EXTERIOR SURFACE TREATMENT: burnished

HEIGHT: $9.1 \mathrm{~cm}$

ORIFICE DIAMETER: $5.7 \mathrm{~cm}$

DIAMETER AT BOTTOM OF RIM OR NECK: $7.4 \mathrm{~cm}$

BASE DIAMETER: $5.7 \mathrm{~cm}$

ESTIMATED VOLUME: 0.3 liters

DECORATION: Four rows of neck banding on the rim (Figure 41)

TYPE: grog-tempered variety of Nash Neck Banded 
Figure 41. Second Nash Neck Banded jar from Burial 6 at the Sherwin site.

SITE NO.: 41CS26

FEATURE: Burial 6

VESSEL NO.: 2047

NON-PLASTICS: grog and hematite

VESSEL FORM: Bottle with a long, straight neck, a direct rim, and a rounded lip

CORE COLOR: $\mathrm{G}$ (fired in a reducing environment and cooled in the open air)

WALL THICKNESS: $3.0 \mathrm{~mm}$ at the neck

INTERIOR SURFACE TREATMENT: none

EXTERIOR SURFACE TREATMENT: smoothed

HEIGHT: $15.2 \mathrm{~cm}$

ORIFICE DIAMETER: $3.6 \mathrm{~cm}$

DIAMETER AT BOTTOM OF RIM OR NECK: $4.9 \mathrm{~cm}$ at the bottom of the neck, 8.7 $\mathrm{cm}$ on the bottle body

BASE DIAMETER: $4.9 \mathrm{~cm}$

ESTIMATED VOLUME: 0.3 liters

DECORATION: There are four sets of interlocking curvilinear engraved scrolls or spirals on the vessel body; on the scrolls or spirals are small hatched triangles. The scrolls are set within a panel defined by a horizontal engraved line at the base of the bottle neck and a second horizontal line just above the base. Separating each interlocking scroll or spiral or hatched pendant triangular elements set around small negative ovals; these are attached to the upper and lower horizontal engraved lines encircling the vessel body (Figure 42).

TYPE: Haley Engraved

Figure 42. Haley Engraved bottle from Burial 6 at the Sherwin site. 


\section{Appendix 4, Vessel Recordation Forms, 41MR12}

SITE NO.: 41MR12

FEATURE: Discovery Vessel

VESSEL NO.: FBR 2

NON-PLASTICS: grog

VESSEL FORM: Carinated bowl with a slightly inverted rim and a rounded lip

CORE COLOR: Undetermined

WALL THICKNESS: $4.9 \mathrm{~mm}$

INTERIOR SURFACE TREATMENT: burnished on the rim

EXTERIOR SURFACE TREATMENT: burnished

HEIGHT: $10.5 \mathrm{~cm}$

ORIFICE DIAMETER: 21.7

DIAMETER AT BOTTOM OF RIM OR NECK: N/A

BASE DIAMETER: $8.0 \mathrm{~cm}$

ESTIMATED VOLUME: 1.4 liters

DECORATION: engraved continuous scroll repeated six times around the rim. A red pigment has been smeared in the engraved lines (Figure 43).

TYPE: Ripley Engraved

Figure 43. FBR 2 vessel, Ripley Engraved, from the Ben McKinney site.

SITE NO.: 41MR12

FEATURE: Burial area

VESSEL NO.: 41MR12-36

NON-PLASTICS: bone 
VESSEL FORM: Carinated bowl with a direct rim, with a rounded and exterior folded lip CORE COLOR: B (fired and cooled in a reducing or low oxygen environment)

WALL THICKNESS: $6.3 \mathrm{~mm}$

INTERIOR SURFACE TREATMENT: burnished on rim

EXTERIOR SURFACE TREATMENT: burnished

HEIGHT: $8.5 \mathrm{~cm}$

ORIFICE DIAMETER: $14.2 \mathrm{~cm}$

DIAMETER AT BOTTOM OF RIM OR NECK: N/A

BASE DIAMETER: $6.0 \mathrm{~cm}$

ESTIMATED VOLUME: 0.7 liters

DECORATION: Engraved with the pendant triangle motif, consisting of upper and low pendant triangles on the rim, a horizontal scroll, and four centrally placed sets of buttons or circles rather than diamonds (Figure 44a-b).

TYPE: Ripley Engraved

Figure 44. Ripley Engraved vessel MR12-36: a, photograph; b, drawing by Bobby Gonzalez.

SITE NO.: 41MR12

FEATURE: Burial area

VESSEL NO.: 41MR12-37

NON-PLASTICS: grog and bone

VESSEL FORM: Bowl with a direct rim and a rounded lip, probably an effigy bowl, based on breaks at the likely area of the attachment of both effigy head and tail (Figure 45 ) on the upper part of the exterior vessel wall.

CORE COLOR: B (fired and cooled in a reducing environment) 
WALL THICKNESS: $6.45 \mathrm{~mm}$

INTERIOR SURFACE TREATMENT: none

EXTERIOR SURFACE TREATMENT: none

HEIGHT: $6.1 \mathrm{~cm}$

ORIFICE DIAMETER: $11.4 \mathrm{~cm}$

DIAMETER AT BOTTOM OF RIM OR NECK: N/A

BASE DIAMETER: $5.6 \mathrm{~cm}$

ESTIMATED VOLUME: 0.28 liters

DECORATION: Plain

TYPE: undetermined effigy bowl ware

Figure 45. Effigy bowl, vessel MR12-37.

SITE NO.: 41MR12

FEATURE: Burial area

VESSEL NO.: 41MR12-38

NON-PLASTICS: grog and bone

VESSEL FORM: carinated bowl with a short and inverted rim and a rounded lip

CORE COLOR: B (fired and cooled in a reducing environment)

WALL THICKNESS: $6.9 \mathrm{~mm}$

INTERIOR SURFACE TREATMENT: smoothed

EXTERIOR SURFACE TREATMENT: burnished

HEIGHT: $11.7 \mathrm{~cm}$

ORIFICE DIAMETER: $15.2 \mathrm{~cm}$ 


\section{DIAMETER AT BOTTOM OF RIM OR NECK: N/A}

BASE DIAMETER: $6.2 \mathrm{~cm}$

ESTIMATED VOLUME: 1.1 liters

DECORATION: Four engraved panels with a central scroll in each panel. Each scroll ends with both lower and upper hatched areas, an apparent continuation of the scroll element. The panels are divided by vertical hatched zones and vertical arcing engraved lines (Figures 46a-b and 47).

TYPE: Simms Engraved

Figure 46. Simms Engraved vessel (MR12-38): a, side view; b, looking down on the rim.

Figure 47. Drawing of the Simms Engraved vessel (MR12-38) by Bobby Gonzalez.

SITE NO.: 41MR12

FEATURE: Burial area

VESSEL NO.: 41MR12-39

NON-PLASTICS: grog and bone

VESSEL FORM: Bottle with a direct rim and a rounded lip, with the neck slightly bulbous and thickened (Figure 48).

CORE COLOR: B (fired and cooled in a reducing environment)

WALL THICKNESS: $3.9 \mathrm{~mm}$

INTERIOR SURFACE TREATMENT: none

EXTERIOR SURFACE TREATMENT: smoothed

HEIGHT: $9.5 \mathrm{~cm}$

ORIFICE DIAMETER: $3.2 \mathrm{~cm}$

DIAMETER AT BOTTOM OF RIM OR NECK: N/A

BASE DIAMETER: $4.2 \mathrm{~cm}$

ESTIMATED VOLUME: 0.16 liters 
DECORATION: Plain

TYPE: Undetermined

Figure 48. Plain bottle, MR12-39.

SITE NO.: 41MR12

FEATURE: Burial area/line of artifacts

VESSEL NO.: 41MR12-40

NON-PLASTICS: grog

VESSEL FORM: Bottle with an inverted rim, and a rounded and exterior folded lip; the bottle body is squat and heavy (Figure 49).

CORE COLOR: Undetermined

WALL THICKNESS: $5.0 \mathrm{~mm}$

INTERIOR SURFACE TREATMENT: none

EXTERIOR SURFACE TREATMENT: burnished

HEIGHT: $9.9 \mathrm{~cm}$

ORIFICE DIAMETER: $2.5 \mathrm{~cm}$ at the neck

DIAMETER AT BOTTOM OF RIM OR NECK: $9.0 \mathrm{~cm}$ at the body

BASE DIAMETER: $4.8 \mathrm{~cm}$

ESTIMATED VOLUME: 0.19 liters

DECORATION: the body has four repeating sets of intertwined hatched scrolls (Figure 49), not particularly well executed.

TYPE: Wilder Engraved

Figure 49. Wilder Engraved bottle, MR12-40.

SITE NO.: 41MR12 
FEATURE: Burial area

VESSEL NO.: 41MR12-41

NON-PLASTICS: none apparent

VESSEL FORM: Carinated bowl with a direct rim and a rounded, exterior folded lip

CORE COLOR: B (fired and cooled in a reducing environment)

WALL THICKNESS: $6.2 \mathrm{~mm}$

INTERIOR SURFACE TREATMENT: burnished on the rim; smoothed on the vessel body

EXTERIOR SURFACE TREATMENT: burnished

HEIGHT: $13.5 \mathrm{~cm}$

ORIFICE DIAMETER: $22.0 \mathrm{~cm}$

DIAMETER AT BOTTOM OF RIM OR NECK: N/A

BASE DIAMETER: $8.5 \mathrm{~cm}$

ESTIMATED VOLUME: 2.6 liters

DECORATION: Continuous engraved scroll motif repeated six times on the vessel rim (Figure 50)

TYPE: Ripley Engraved

Figure 50. Ripley Engraved vessel, MR12-41.

SITE NO.: 41MR12

FEATURE: Burial II

VESSEL NO.: 41MR12-42

NON-PLASTICS: grog

VESSEL FORM: Carinated bowl with a direct rim and rounded, exterior folded, lip 
CORE COLOR: Undetermined

WALL THICKNESS: $5.4 \mathrm{~mm}$

INTERIOR SURFACE TREATMENT: smoothed

EXTERIOR SURFACE TREATMENT: smoothed

HEIGHT: $7.5 \mathrm{~cm}$

ORIFICE DIAMETER: $14.0 \mathrm{~cm}$

DIAMETER AT BOTTOM OF RIM OR NECK: N/A

BASE DIAMETER: $5.0 \mathrm{~cm}$

ESTIMATED VOLUME: 0.8 liters

DECORATION: Engraved pendant triangle motif, with the central element repeated four times: twice as a circle (with a smaller central circle within it) and twice as opposed vertical arcs or parentheses (Figure 51).

TYPE: Ripley Engraved

Figure 51. Ripley Engraved vessel from Burial II, MR12-42.

SITE NO.: 41MR12

FEATURE: Burial I

VESSEL NO.: 41MR12-43

NON-PLASTICS: grog, with a sandy paste

VESSEL FORM: Carinated bowl with a direct rim and a rounded lip

CORE COLOR: Undetermined

WALL THICKNESS: $5.3 \mathrm{~mm}$

INTERIOR SURFACE TREATMENT: none

EXTERIOR SURFACE TREATMENT: smoothed 
HEIGHT: $7.6 \mathrm{~cm}$

ORIFICE DIAMETER: $13.0 \mathrm{~cm}$

DIAMETER AT BOTTOM OF RIM OR NECK: N/A

BASE DIAMETER: $6.5 \mathrm{~cm}$

ESTIMATED VOLUME: 0.6 liters

DECORATION: interlocking curvilinear engraved scroll repeated six times on the vessel rim. There are hatched zones both above and below each of the scrolls (Figure 52).

TYPE: Taylor Engraved

Figure 52. Taylor Engraved vessel from Burial I at the Ben McKinney site, MR12-43.

SITE NO.: 41MR12

FEATURE: Burial III

VESSEL NO.: 41MR12-44

NON-PLASTICS: grog and bone

VESSEL FORM: Carinated bowl with a direct rim and a rounded, exterior folded, lip

CORE COLOR: B (fired and cooled in a reducing environment)

WALL THICKNESS: $6.5 \mathrm{~mm}$

INTERIOR SURFACE TREATMENT: smoothed

EXTERIOR SURFACE TREATMENT: burnished

HEIGHT: $6.3 \mathrm{~cm}$

ORIFICE DIAMETER: $14.2 \mathrm{~cm}$

DIAMETER AT BOTTOM OF RIM OR NECK: N/A

BASE DIAMETER: $5.6 \mathrm{~cm}$

ESTIMATED VOLUME: 0.55 liters 
DECORATION: interlocking curvilinear engraved scroll repeated eight times on the vessel rim. There are hatched zones both above and below each of the scrolls. A red clay pigment has been rubbed into the engraved lines (Figure 53).

TYPE: Taylor Engraved

Figure 53. Taylor Engraved vessel from Burial III at the Ben McKinney site, MR12-44.

SITE NO.: 41MR12

FEATURE: Burial III

VESSEL NO.: 41MR12-45

NON-PLASTICS: grog and bone

VESSEL FORM: Carinated bowl with a direct rim and a rounded, exterior folded, lip

CORE COLOR: Undetermined

WALL THICKNESS: $8.2 \mathrm{~mm}$

INTERIOR SURFACE TREATMENT: none

EXTERIOR SURFACE TREATMENT: none

HEIGHT: $7.3 \mathrm{~cm}$

ORIFICE DIAMETER: $12.7 \mathrm{~cm}$

DIAMETER AT BOTTOM OF RIM OR NECK: N/A

BASE DIAMETER: $6.8 \mathrm{~cm}$

ESTIMATED VOLUME: 0.55 liters

DECORATION: Interlocking horizontal engraved scroll repeated four times around the rim. Each scroll element is separated by a divider composed of vertical opposing arcing lines and small excised pendant triangle elements (Figure 54).

TYPE: Ripley Engraved

Figure 54. Ripley Engraved vessel (MR12-45) from Burial III at the Ben McKinney site. 
SITE NO.: 41MR12

FEATURE: Burial III

VESSEL NO.: 41MR12-46

NON-PLASTICS: grog

VESSEL FORM: Double or compound vessel, upper part is a carinated bowl and the lower part is a bottle body form (Figure 55). There are two suspension holes on the rim of the carinated bowl part of the vessel.

CORE COLOR: Undetermined

WALL THICKNESS: $4.1 \mathrm{~mm}$

INTERIOR SURFACE TREATMENT: smoothed on the carinated bowl part of the vessel

EXTERIOR SURFACE TREATMENT: burnished

HEIGHT: $13.0 \mathrm{~cm}$

ORIFICE DIAMETER: $8.4 \mathrm{~cm}$ on the carinated bowl part of the vessel

DIAMETER AT BOTTOM OF RIM OR NECK: N/A

BASE DIAMETER: undetermined, rounded base

ESTIMATED VOLUME: 0.65 liters

DECORATION: The carinated bowl portion of the vessel has discontinuous hatched scrolls repeated three times (characteristic of var. Darco of the Simms Engraved type), as well as two horizontal engraved lines on the body part of the carinated bowl section (Figures 55 and 56a) while the bottle portion of the vessel (the Hodges Engraved decoration) has cross-hatched zones with negative ovals and curvilinear scrolls (Figures 55 and $56 \mathrm{~b})$.

TYPE: Simms Engraved, var. Darco (see Perttula 2007) and Hodges Engraved

Figure 55. Compound engraved vessel with Simms Engraved and Hodges Engraved motifs, MR12-46. 
Figure 56. Drawing of Simms-Hodges Engraved compound vessel, MR12-46: a, side view; b, showing the bottom of the Hodges Engraved portion of the vessel.

SITE NO.: 41MR12

FEATURE: Burial I

VESSEL NO.: 41MR12-47

NON-PLASTICS: grog and bone

VESSEL FORM: Jar with a short everted rim and a rounded, exterior folded, lip

CORE COLOR: Undetermined

WALL THICKNESS: $8.2 \mathrm{~mm}$

INTERIOR SURFACE TREATMENT: none

EXTERIOR SURFACE TREATMENT: none

HEIGHT: $14.0 \mathrm{~cm}$

ORIFICE DIAMETER: $10.2 \mathrm{~cm}$

DIAMETER AT BOTTOM OF RIM OR NECK: $10.4 \mathrm{~cm}$

BASE DIAMETER: $8.1 \mathrm{~cm}$

ESTIMATED VOLUME: 0.85 liters

DECORATION: There are two rows of tool punctations on the short vessel rim, and multiple vertical appliqued ridges on the vessel body. The appliqued ridges extend from the rim-body juncture to just above the vessel base (Figure 57).

TYPE: Cass Appliqued

Figure 57. Cass Appliqued jar from Burial I, MR12-47.

SITE NO.: 41MR12

FEATURE: Burial II 
VESSEL NO.: 41MR12-48

NON-PLASTICS: grog

VESSEL FORM: Carinated bowl with a direct rim and a rounded, exterior folded, lip

CORE COLOR: Undetermined

WALL THICKNESS: $5.6 \mathrm{~mm}$

INTERIOR SURFACE TREATMENT: red slipped

EXTERIOR SURFACE TREATMENT: red slipped

HEIGHT: $6.5 \mathrm{~cm}$

ORIFICE DIAMETER: $14.4 \mathrm{~cm}$

DIAMETER AT BOTTOM OF RIM OR NECK: N/A

BASE DIAMETER: $5.8 \mathrm{~cm}$

ESTIMATED VOLUME: 0.6 liters

DECORATION: The decoration is an engraved scroll and circle motif repeated four times on the vessel rim; the engraved motif was cut through a red-slipped vessel body (Figure 58).

TYPE: Ripley Engraved

Figure 58. Red-slipped Ripley Engraved vessel from Burial II, MR12-48.

SITE NO.: 41MR12

FEATURE: Burial II

VESSEL NO.: 41MR12-49

NON-PLASTICS: grog and bone

VESSEL FORM: Carinated bowl with an everted rim and a rounded lip. The vessel also has eight dramatically sweeping rim peaks (Figure 59a).

CORE COLOR: Undetermined 
WALL THICKNESS: $5.4 \mathrm{~mm}$

INTERIOR SURFACE TREATMENT: smoothed

EXTERIOR SURFACE TREATMENT: burnished

HEIGHT: $8.3 \mathrm{~cm}$; height at rim peak of $8.7 \mathrm{~cm}$

ORIFICE DIAMETER: $21.1 \mathrm{~cm}$

DIAMETER AT BOTTOM OF RIM OR NECK: N/A

BASE DIAMETER: $5.0 \mathrm{~cm}$

ESTIMATED VOLUME: 1.1 liters

DECORATION: There are two different decorative elements on the vessel rim. Immediately under the lip and the rim peaks are a series of closely-spaced vertically incised lines. The remainder of the rim has an engraved continuous scroll motif repeated four times around the rim, with a central circle element (Figure 59a and Figure 60a). The combination of vertical incising and an engraved motif on the rim is stylistically diagnostic of the recently defined var. Walkers Creek of the Ripley Engraved type (Perttula, ed. 2005).

This vessel from the Ben McKinney site stands apart from other Ripley Engraved vessels because it also has elaborate engraved designs covering the vessel body and base. The body and base engraved decorations consist of a central rectangular element surrounding a circular element (defined by two lines); the corners of the rectangle are hatched, and two of the corners also have smaller engraved triangles that intersect of the hatched lines (Figures 59b and 60b). The central rectangular and circular motif is juxtaposed with four curvilinear zones filled with sets of closely-spaced vertical hatched lines.

TYPE: Ripley Engraved, var. Walkers Creek

Figure 59. Ripley Engraved, var. Walkers Creek vessel, MR12-49: a, side view; b, bottom view.

Figure 60. Drawing by Bobby Gonzalez of Ripley Engraved, var. Walkers Creek vessel: a, side view; b, bottom view.

SITE NO.: 41MR12

FEATURE: Burial II 
VESSEL NO.: 41MR12-50

NON-PLASTICS: grog

VESSEL FORM: Carinated bowl with a direct rim and a rounded lip

CORE COLOR: B (fired and cooled in a reducing environment)

WALL THICKNESS: $6.7 \mathrm{~mm}$

INTERIOR SURFACE TREATMENT: smoothed; organic residue

EXTERIOR SURFACE TREATMENT: smoothed; organic residue

HEIGHT: $12.8 \mathrm{~cm}$

ORIFICE DIAMETER: $24.4 \mathrm{~cm}$

DIAMETER AT BOTTOM OF RIM OR NECK: N/A

BASE DIAMETER: $9.0 \mathrm{~cm}$

ESTIMATED VOLUME: 1.9 liters

DECORATION: the rim has an engraved pendant triangle and diamond motif; the central diamond element is repeated four times around the rim (Figure 61).

TYPE: Ripley Engraved

Figure 61. Ripley Engraved vessel (MR12-50) from Burial II at the Ben McKinney site.

SITE NO.: 41MR12

FEATURE: Burial I

VESSEL NO.: 41MR12-51

NON-PLASTICS: grog and bone

VESSEL FORM: Carinated bowl with a direct rim and a rounded, slightly exterior folded, lip

CORE COLOR: B (fired and cooled in a reducing environment) 
WALL THICKNESS: $6.1 \mathrm{~mm}$

INTERIOR SURFACE TREATMENT: smoothed

EXTERIOR SURFACE TREATMENT: smoothed

HEIGHT: $11.2 \mathrm{~cm}$

ORIFICE DIAMETER: $19.1 \mathrm{~cm}$

DIAMETER AT BOTTOM OF RIM OR NECK: N/A

BASE DIAMETER: $5.7 \mathrm{~cm}$

ESTIMATED VOLUME: 1.3 liters

DECORATION: Engraved interlocking scrolls repeated four times on the vessel rim. There are zones filled with 20 curvilinear lines both above and below the scroll element, and the central scroll line has a series of small triangular tick marks on it (Figure 62).

TYPE: Taylor Engraved

Figure 62. Taylor Engraved vessel MR12-51 from Burial I at the Ben McKinney site.

SITE NO.: 41MR12

FEATURE: Burial I

VESSEL NO.: 41MR12-52

NON-PLASTICS: grog and bone

VESSEL FORM: Compound bowl with an everted rim and a rounded lip

CORE COLOR: B (fired and cooled in a reducing environment)

WALL THICKNESS: $7.0 \mathrm{~mm}$

INTERIOR SURFACE TREATMENT: none

EXTERIOR SURFACE TREATMENT: none

HEIGHT: $27.2 \mathrm{~cm}$ 
ORIFICE DIAMETER: $27.5 \mathrm{~cm}$

DIAMETER AT BOTTOM OF RIM OR NECK: $29.0 \mathrm{~cm}$ at the carination of the lower rim panel

BASE DIAMETER: $9.4 \mathrm{~cm}$

ESTIMATED VOLUME: 6.0 liters

DECORATION: The upper rim panel is plain, but the lower panel has engraved interlocking horizontal scrolls (Figure 63). There are hour-glass shaped engraved elements on either end of the central scroll line. Each of the interlocking scrolls are divided by other hour-glass-shaped engraved elements that extend from the rim to the vessel carination.

TYPE: Ripley Engraved

Figure 63. Ripley Engraved compound bowl, MR12-52, from Burial I at the Ben McKinney site.

SITE NO.: 41MR12

FEATURE: Burial III

VESSEL NO.: 41MR12-53

NON-PLASTICS: grog and bone

VESSEL FORM: Jar with a short but direct rim and a flat, exterior folded, lip

CORE COLOR: Undetermined

WALL THICKNESS: $6.9 \mathrm{~mm}$

INTERIOR SURFACE TREATMENT: smoothed

EXTERIOR SURFACE TREATMENT: smoothed

HEIGHT: $15.5 \mathrm{~cm}$

ORIFICE DIAMETER: $10.0 \mathrm{~cm}$

DIAMETER AT BOTTOM OF RIM OR NECK: $9.8 \mathrm{~cm}$ 
BASE DIAMETER: $7.0 \mathrm{~cm}$

ESTIMATED VOLUME: 0.9 liters

DECORATION: The short rim has a series of vertical incised lines that extend from near the lip to the rim-body juncture (Figure 64a-b). The vessel body has a series of carelessly engraved interlocking curvilinear scrolls that repeat five times on the vessel. Above each scroll is a large triangular-shaped area, and there are three closely-spaced horizontal lines encircling the vessel both above and below the scroll motif.

TYPE: Undetermined, but possibly a variety of Taylor Engraved

Figure 64. Engraved and incised jar, MR12-53, from Burial III at the Ben McKinney site: a, photograph; b, drawing by Bobby Gonzalez.

SITE NO.: 41MR12

FEATURE: Burial III

VESSEL NO.: 41MR12-54

NON-PLASTICS: grog

VESSEL FORM: Bowl with a direct rim and a rounded, exterior folded, lip

CORE COLOR: $\mathrm{F}$ (fired in a reducing environment but cooled in the open air)

WALL THICKNESS: $6.1 \mathrm{~mm}$

INTERIOR SURFACE TREATMENT: smoothed only on the rim

EXTERIOR SURFACE TREATMENT: burnished

HEIGHT: $7.5 \mathrm{~cm}$

ORIFICE DIAMETER: $13.8 \mathrm{~cm}$

DIAMETER AT BOTTOM OF RIM OR NECK: N/A

BASE DIAMETER: $5.7 \mathrm{~cm}$

ESTIMATED VOLUME: 0.4 liters 
DECORATION: The rim has a series of seven interlocking engraved scrolls between horizontal lines under the lip and farther down the rim (Figure 65). Each of the scrolls are divided by nine $\mathrm{X}$-shaped or cross-hatched engraved elements that extend between the two horizontal engraved lines. A white kaolin clay pigment has been rubbed into the engraved lines. There also is a single horizontal engraved line on the interior of the vessel at the rim-body juncture.

TYPE: Ripley Engraved

Figure 65. Ripley Engraved vessel from Burial III at the Ben McKinney site, MR12-54.

SITE NO.: 41MR12

FEATURE: Burial I

VESSEL NO.: 41MR12-55

NON-PLASTICS: grog, bone, and hematite

VESSEL FORM: Globular compound bowl with peaked rims; the rims are otherwise direct, with flat and exterior folded lips. There are two suspension holes on the upper panel, just under the lip.

CORE COLOR: Undetermined

WALL THICKNESS: $6.9 \mathrm{~mm}$

INTERIOR SURFACE TREATMENT: smoothed

EXTERIOR SURFACE TREATMENT: smoothed

HEIGHT: $11.2 \mathrm{~cm}$

ORIFICE DIAMETER: $11.8 \mathrm{~cm}$

DIAMETER AT BOTTOM OF RIM OR NECK: $11.6 \mathrm{~cm}$

BASE DIAMETER: $7.8 \mathrm{~cm}$

ESTIMATED VOLUME: 1.1 liters

DECORATION: The upper panel of the compound bowl has a simple scroll motif repeated four times across the panel. Each of these scrolls is separated by excised hour- 
glass shaped areas and there are excised zones both above and below the scroll on this upper panel (Figure 66a-b).

The lower panel has a single horizontal engraved line at the top, followed by two series of four circles repeated four times across the panel. The innermost circle begins as an interlocking engraved hooks or arms. There are engraved tick marks between the sets of circles (see Figure 66a-b).

TYPE: Ripley Engraved-Taylor Engraved combination

Figure 66. Vessel MR12-55, a Ripley-Taylor Engraved compound bowl from Burial I: a, photograph; b, drawing by Bobby Gonzalez.

SITE NO.: 41MR12

FEATURE: Burial I

VESSEL NO.: 41MR12-56

NON-PLASTICS: grog

VESSEL FORM: Carinated bowl with a direct rim and a rounded and exterior folded lip

CORE COLOR: Undetermined

WALL THICKNESS: $5.4 \mathrm{~mm}$

INTERIOR SURFACE TREATMENT: smoothed

EXTERIOR SURFACE TREATMENT: burnished

HEIGHT: $7.5 \mathrm{~cm}$

ORIFICE DIAMETER: $18.5 \mathrm{~cm}$

DIAMETER AT BOTTOM OF RIM OR NECK: N/A

BASE DIAMETER: $7.5 \mathrm{~cm}$

ESTIMATED VOLUME: 0.8 liters

DECORATION: Engraved with a continuous scroll motif repeated four times across the rim (Figure 67). A single horizontal engraved line encircles the vessel interior at the rimbody juncture. A white kaolin clay pigment has been rubbed in the engraved lines. 
TYPE: Ripley Engraved

Figure 67. Ripley Engraved vessel, MR12-56, from Burial I at the Ben McKinney site.

SITE NO.: 41MR12

FEATURE: Burial II

VESSEL NO.: 41MR12-57

NON-PLASTICS: grog

VESSEL FORM: Carinated bowl with a direct rim and a rounded, exterior folded, lip

CORE COLOR: Undetermined

WALL THICKNESS: $5.5 \mathrm{~mm}$

INTERIOR SURFACE TREATMENT: smoothed

EXTERIOR SURFACE TREATMENT: smoothed

HEIGHT: $7.9 \mathrm{~cm}$

ORIFICE DIAMETER: $17.1 \mathrm{~cm}$

DIAMETER AT BOTTOM OF RIM OR NECK: N/A

BASE DIAMETER: $7.1 \mathrm{~cm}$

ESTIMATED VOLUME: 0.8 liters

DECORATION: Engraved on the rim with a horizontal scroll repeated four times around the vessel rim. Each scroll is divided by a single vertical engraved line. Above and below each horizontal scroll are a series of small pendant triangles (Figure 68).

TYPE: Ripley Engraved

Figure 68. Ripley Engraved vessel from Burial II at the Ben McKinney site (MR12-57).

SITE NO.: 41MR12 
FEATURE: Burial III

VESSEL NO.: 41MR12-58

NON-PLASTICS: grog and hematite, with a sandy paste

VESSEL FORM: Miniature bowl with a direct rim and a rounded, exterior folded lip

CORE COLOR: $\mathrm{F}$ (fired in a reducing environment, but cooled in the open air)

WALL THICKNESS: $4.3 \mathrm{~mm}$

INTERIOR SURFACE TREATMENT: smoothed

EXTERIOR SURFACE TREATMENT: smoothed

HEIGHT: $2.6 \mathrm{~cm}$

ORIFICE DIAMETER: $6.6 \mathrm{~cm}$

DIAMETER AT BOTTOM OF RIM OR NECK: N/A

BASE DIAMETER: $3.8 \mathrm{~cm}$

ESTIMATED VOLUME: 0.07 liters

DECORATION: The bowl has seven engraved zones or hooked elements that repeatedly interlock around the vessel. Each of these distinctive engraved zones is filled with small circular punctations (Figure 69).

TYPE: Undetermined, but possibly a variety of Taylor Engraved

Figure 69. Miniature engraved-punctated bowl (MR12-58) from Burial III at the Ben McKinney site.

SITE NO.: 41MR12

FEATURE: Burial III

VESSEL NO.: 41MR12-59

NON-PLASTICS: grog

VESSEL FORM: Jar with an everted rim and a rounded, exterior folded, lip 
CORE COLOR: Undetermined

WALL THICKNESS: $9.5 \mathrm{~mm}$

INTERIOR SURFACE TREATMENT: smoothed

EXTERIOR SURFACE TREATMENT: none

HEIGHT: $32.2 \mathrm{~cm}$

ORIFICE DIAMETER: $29.0 \mathrm{~cm}$

DIAMETER AT BOTTOM OF RIM OR NECK: $28.0 \mathrm{~cm}$

BASE DIAMETER: $10.5 \mathrm{~cm}$

ESTIMATED VOLUME: 12.1 liters

DECORATION: The rim has a series of 24 nested incised triangles (each defined by four incised lines), 12 of which point downwards from the rim and the other 12 point upwards from the rim-body juncture. The vessel body has a vertical brushing decoration (Figure $70)$.

TYPE: Maydelle Incised

Figure 70. Maydelle Incised jar from Burial III at the Ben McKinney site.

SITE NO.: 41MR12

FEATURE: Line of Artifacts

VESSEL NO.: 41MR12-60

NON-PLASTICS: grog and bone

VESSEL FORM: Carinated bowl with a short inverted rim and a rounded lip

CORE COLOR: Undetermined

WALL THICKNESS: $5.5 \mathrm{~mm}$

INTERIOR SURFACE TREATMENT: Smoothed 
EXTERIOR SURFACE TREATMENT: Burnished

HEIGHT: $10.5 \mathrm{~cm}$

ORIFICE DIAMETER: $15.3 \mathrm{~cm}$

DIAMETER AT BOTTOM OF RIM OR NECK: $16.5 \mathrm{~cm}$

BASE DIAMETER: $7.0 \mathrm{~cm}$

ESTIMATED VOLUME: 1.0 liters

DECORATION: The short rim has a cross-hatched engraved panel that encircles the vessel. The top and bottom of the panel are defined by single horizontal engraved lines that encircle the vessel rim (Figure 71).

TYPE: Simms Engraved

Figure 71. Simms Engraved carinated bowl from "line of artifacts" at the Ben McKinney site.

SITE NO.: 41MR12

FEATURE: Burial III

VESSEL NO.: 41MR12-61

NON-PLASTICS: grog

VESSEL FORM: Compound Bowl with a direct to slightly everted rim and a rounded, exterior folded, lip

CORE COLOR: Undetermined

WALL THICKNESS: $6.7 \mathrm{~mm}$

INTERIOR SURFACE TREATMENT: smoothed on upper rim panel

EXTERIOR SURFACE TREATMENT: smoothed

HEIGHT: $13.5 \mathrm{~cm}$

ORIFICE DIAMETER: $23.5 \mathrm{~cm}$ 


\section{DIAMETER AT BOTTOM OF RIM OR NECK: N/A}

BASE DIAMETER: $7.3 \mathrm{~cm}$

ESTIMATED VOLUME: 2.5 liters

DECORATION: The upper panel has six engraved circles (with two lines) divided by vertical panels with two negative semi-circles (and a central dot) and excised areas. The lower panel has a repeating series of engraved triangles, each of which have small excised triangles; the triangles point upwards to the vessel rim. A white kaolin clay pigment has been rubbed in the engraved lines (Figure 72).

TYPE: Undetermined

Figure 72. Engraved compound bowl from Burial III at the Ben McKinney site.

SITE NO.: 41MR12

FEATURE: Line of Artifacts

VESSEL NO.: 41MR12-63

NON-PLASTICS: grog

VESSEL FORM: Carinated bowl with a direct rim and a rounded, exterior folded, lip

CORE COLOR: B (fired and cooled in a reducing environment)

WALL THICKNESS: $5.4 \mathrm{~mm}$

INTERIOR SURFACE TREATMENT: smoothed

EXTERIOR SURFACE TREATMENT: burnished

HEIGHT: $6.0 \mathrm{~cm}$

ORIFICE DIAMETER: $14.5 \mathrm{~cm}$

DIAMETER AT BOTTOM OF RIM OR NECK: N/A

BASE DIAMETER: $6.0 \mathrm{~cm}$

ESTIMATED VOLUME: 0.5 liters 
DECORATION: Engraved on the rim with the pendant triangle motif, consisting of horizontal scrolls on either side of a central circle or button element, and small pendant triangles both above and below the horizontal scroll. On this vessel, the central circle or button element is repeated twice on the rim (Figure 73).

TYPE: Ripley Engraved

Figure 73. Ripley Engraved carinated bowl from the "line of artifacts" at the Ben McKinney site.

SITE NO.: 41MR12

FEATURE: Burial I

VESSEL NO.: 41MR12-65

NON-PLASTICS: grog

VESSEL FORM: Bottle with a direct rim and a rounded but slight exterior folded lip

CORE COLOR: B (fired and cooled in a reducing environment)

WALL THICKNESS: N/A

INTERIOR SURFACE TREATMENT: none

EXTERIOR SURFACE TREATMENT: burnished

HEIGHT: $10.1 \mathrm{~cm}$

ORIFICE DIAMETER: $3.4 \mathrm{~cm}$ at the neck

DIAMETER AT BOTTOM OF RIM OR NECK: $8.3 \mathrm{~cm}$ on the bottle body

BASE DIAMETER: $4.3 \mathrm{~cm}$

ESTIMATED VOLUME: 0.17 liters

DECORATION: Engraved spirals or scrolls and hooked arms that are repeated four times on the vessel body. There are hatched zones both above and below the spirals or scrolls, and these are pendant from sets of horizontal engraved lines that encircle the top (3 lines) and bottom (2 lines) of the vessel body (Figure 74).

TYPE: Taylor Engraved 
Figure 74. Taylor Engraved bottle (MR12-65) from Burial I at the Ben McKinney site.

SITE NO.: 41MR12

FEATURE: $12 \mathrm{ft}$. south of Burial II

VESSEL NO.: 41MR12-66

NON-PLASTICS: bone

VESSEL FORM: Bottle, with a missing bottle neck (Figure 75)

CORE COLOR: B (fired and cooled in a reducing environment)

WALL THICKNESS: N/A

INTERIOR SURFACE TREATMENT: none

EXTERIOR SURFACE TREATMENT: smoothed

HEIGHT: $7.4 \mathrm{~cm}+$

ORIFICE DIAMETER: $2.8 \mathrm{~cm}$ at the bottle neck/body attachment

DIAMETER AT BOTTOM OF RIM OR NECK: N/A

BASE DIAMETER: $5.8 \mathrm{~cm}$

ESTIMATED VOLUME: $>0.17$ liters

DECORATION: Plain

TYPE: Undetermined

Figure 75. Plain bottle, MR12-66, found south of Burial II at the Ben McKinney site.

SITE NO.: 41MR12

FEATURE: Burial III

VESSEL NO.: 41MR12-67 
NON-PLASTICS: none apparent

VESSEL FORM: Bottle with a slight spool-shaped neck and a carinated body. The rim is direct, and the lip is rounded and exterior folded.

CORE COLOR: B (fired and cooled in a reducing environment)

WALL THICKNESS: $4.6 \mathrm{~mm}$

INTERIOR SURFACE TREATMENT: none

EXTERIOR SURFACE TREATMENT: smoothed

HEIGHT: $15.6 \mathrm{~cm}$

ORIFICE DIAMETER: $4.0 \mathrm{~cm}$ at the neck

DIAMETER AT BOTTOM OF RIM OR NECK: $13.1 \mathrm{~cm}$ on the vessel body

BASE DIAMETER: $6.2 \mathrm{~cm}$

ESTIMATED VOLUME: 0.4 liters

DECORATION: The bottle body has an engraved-punctated decoration. The engraved elements consist of a central semi-circle (composed of five lines per circle) that is repeated three times around the vessel, and with three repeating upper and lower sets of semi-circles (four lines per semi-circle) on either side of the central circle. The areas between the central circles and the upper and lower semi-circles are filled with small tool punctations (Figures 76a-b and 77).

TYPE: Bailey Engraved

Figure 76. Bailey Engraved bottle from Burial III: a, side view; b, bottom view.

Figure 77. Drawing of the Bailey Engraved bottle (MR12-67) by Bobby Gonzalez.

SITE NO.: 41MR12

FEATURE: Burial II

VESSEL NO.: 41MR12-68

NON-PLASTICS: grog and hematite 
VESSEL FORM: Bottle with a direct rim and a rounded but exterior folded lip

CORE COLOR: Undetermined

WALL THICKNESS: $8.6 \mathrm{~mm}$ on the neck

INTERIOR SURFACE TREATMENT: none

EXTERIOR SURFACE TREATMENT: smoothed

HEIGHT: $22.0 \mathrm{~cm}$

ORIFICE DIAMETER: $3.4 \mathrm{~cm}$ at the neck

DIAMETER AT BOTTOM OF RIM OR NECK: $5.3 \mathrm{~cm}$ at the neck and body juncture

BASE DIAMETER: $8.1 \mathrm{~cm}$

ESTIMATED VOLUME: 0.7 liters

DECORATION: The bottle body has an engraved-punctated decoration. The principal decorative motif is one of large engraved circles repeated four times around the vessel; each circle is comprised of 10 closely-spaced lines (Figure 78). Above each circle are three semi-circular engraved lines, and above that (and encircling the upper bottle body) is a zone filled with small punctations. There is also a single horizontal engraved line just below the bottle neck rim. Finally, a red pigment has been rubbed into the engraved design on the vessel body.

TYPE: Bailey Engraved

Figure 78. Bailey Engraved bottle from Burial II at the Ben McKinney site.

SITE NO.: 41MR12

FEATURE: Burial III

VESSEL NO.: 41MR12-71

NON-PLASTICS: grog

VESSEL FORM: Jar with a direct rim and a rounded, exterior folded lip. There are four peaks along the rim, and strap handles are attached just below the lip and directly under each of the rim peaks. 
CORE COLOR: Undetermined

WALL THICKNESS: $7.5 \mathrm{~mm}$

INTERIOR SURFACE TREATMENT: smoothed

EXTERIOR SURFACE TREATMENT: none

HEIGHT: $19.0 \mathrm{~cm} ; 20.0 \mathrm{~cm}$ at the rim peaks

ORIFICE DIAMETER: $19.0 \mathrm{~cm}$

DIAMETER AT BOTTOM OF RIM OR NECK: $18.9 \mathrm{~cm}$

BASE DIAMETER: $7.6 \mathrm{~cm}$

ESTIMATED VOLUME: 3.2 liters

DECORATION: The rim has an incised-punctated decoration. There is a single row of tool punctations under the lip, and eight sets of opposed incised lines, two sets between each strap handle. Each of the strap handles has vertical incised lines and vertical appliqued ridges on it (Figure 79).

The jar body is covered with appliqued elements. This includes four horizontal appliqued ridges, two at the top and bottom, respectively of the jar body; the top two begin at the rim-body juncture. Between these horizontal appliqued strips are eight sets of appliqued diamonds in panels defined by intersecting diagonal appliqued strips. There are repeating triangular-shaped appliqued elements pendant from the second of the two horizontal appliqued strips at the top of the vessel body (see Figure 79).

TYPE: Harleton Appliqued

Figure 79. Harleton Appliqued jar from Burial III at the Ben McKinney site.

SITE NO.: 41MR12

FEATURE: Burial I

VESSEL NO.: 41MR12-72

NON-PLASTICS: bone

VESSEL FORM: Carinated bowl with a direct rim and a rounded, exterior folded lip. There are four small rim peaks on the vessel (Figure 80a). 
CORE COLOR: B (fired and cooled in a reducing or low oxygen environment)

WALL THICKNESS: $6.0 \mathrm{~mm}$

INTERIOR SURFACE TREATMENT: smoothed

EXTERIOR SURFACE TREATMENT: smoothed

HEIGHT: $6.7 \mathrm{~cm}$

ORIFICE DIAMETER: $15.0 \mathrm{~cm}$

DIAMETER AT BOTTOM OF RIM OR NECK: $15.1 \mathrm{~cm}$

BASE DIAMETER: $5.0 \mathrm{~cm}$

ESTIMATED VOLUME: 0.6 liters

DECORATION: The engraving on the rim consists of interlocking scrolls repeated four times across the rim. The central scroll line has small tick marks on it (Figures 80a and 81). Above and below each scroll are triangular-shaped areas with hatched engraved lines. A red pigment has been rubbed into the engraved lines.

The carinated bowl body is also decorated. The base has an engraved circle around its edges with four pendant triangles (Figure 80b); there are small dots or punctates within each of the pendant triangles. On the vessel body, there are four scrollshaped zones filled with small tool punctations, and these punctate-filled scroll zones are either attached to or wrapped around a small engraved scroll with a hooked arm.

TYPE: Taylor Engraved

Figure 80. Taylor Engraved vessel (MR12-72) from Burial I at the Ben McKinney site: a, side view; b, bottom view.

Figure 81. Drawing of Taylor Engraved carinated bowl from Burial I at the Ben McKinney site.

SITE NO.: 41MR12

FEATURE: Burial I

VESSEL NO.: 41MR12-73 
NON-PLASTICS: grog, bone, and hematite

VESSEL FORM: Compound bowl with four rim peaks. The rim is strongly everted and has a rounded lip (Figure 82a). Viewed from below, the vessel is square in appearance (Figure 82b).

CORE COLOR: $\mathrm{F}$ (fired in a reducing environment, but cooled in the open air)

WALL THICKNESS: $7.2 \mathrm{~mm}$

INTERIOR SURFACE TREATMENT: smoothed on the upper rim panel

EXTERIOR SURFACE TREATMENT: burnished

HEIGHT: $10.5 \mathrm{~cm}$

ORIFICE DIAMETER: $17.9 \mathrm{~cm}$

DIAMETER AT BOTTOM OF RIM OR NECK: N/A

BASE DIAMETER: $7.2 \mathrm{~cm}$

ESTIMATED VOLUME: 1.5 liters

DECORATION: The upper panel has four engraved circles (set immediately under each of the rim peaks and with two lines per circle, as well as a central dot) and small excised triangles on either side of the circles (Figure 82a). The circles and small excised triangles are in four zones on the upper panel that are defined by two vertical engraved lines. The lower panel has an engraved scroll and circle motif that is repeated four times on the vessel.

TYPE: Ripley Engraved

Figure 82. Ripley Engraved compound bowl from Burial I at the Ben McKinney site: a, side view; b, bottom view.

SITE NO.: 41MR12

FEATURE: Burial III

VESSEL NO.: 41MR12-74

NON-PLASTICS: very finely-crushed grog 
VESSEL FORM: Carinated bowl with a direct rim and a rounded, exterior folded lip

CORE COLOR: B (fired and cooled in a reducing environment)

WALL THICKNESS: $5.6 \mathrm{~mm}$

INTERIOR SURFACE TREATMENT: burnished; there is an organic residue on the rim EXTERIOR SURFACE TREATMENT: burnished; there is an organic residue on the upper body of the vessel

HEIGHT: $10.5 \mathrm{~cm}$

ORIFICE DIAMETER: $20.9 \mathrm{~cm}$

DIAMETER AT BOTTOM OF RIM OR NECK: $20.5 \mathrm{~cm}$

BASE DIAMETER: $6.8 \mathrm{~cm}$

ESTIMATED VOLUME: 1.3 liters

DECORATION: The engraved design on the vessel rim is the pendant triangle motif (Thurmond 1990: Figure 6a). This motif is comprised of two alternating diamonds and buttons as the central elements as well as rows of small pendant triangles above and below the central engraved elements (Figure 83). A white kaolin clay pigment has been rubbed in the engraved lines.

TYPE: Ripley Engraved

Figure 83. Ripley Engraved carinated bowl from Burial III at the Ben McKinney site.

SITE NO.: 41MR12

FEATURE: Burial I

VESSEL NO.: 41MR12-75

NON-PLASTICS: grog and bone

VESSEL FORM: Carinated bowl with a direct rim and a rounded lip

CORE COLOR: F (fired in a reducing environment, but cooled in the open air)

WALL THICKNESS: $6.8 \mathrm{~mm}$ 
INTERIOR SURFACE TREATMENT: none

EXTERIOR SURFACE TREATMENT: smoothed

HEIGHT: $10.5 \mathrm{~cm}$

ORIFICE DIAMETER: $22.2 \mathrm{~cm}$

DIAMETER AT BOTTOM OF RIM OR NECK: $22.0 \mathrm{~cm}$

BASE DIAMETER: $8.0 \mathrm{~cm}$

ESTIMATED VOLUME: 1.4 liters

DECORATION: The rim has four sets of hooked arm scrolls repeated around the vessel, and each of the two sets of hooked arms abut each other (Figure 84). Above and below the scrolls are hatched engraved zones.

TYPE: Taylor Engraved

Figure 84. Taylor Engraved carinated bowl (MR12-75) from Burial I at the Ben McKinney site.

SITE NO.: 41MR12

FEATURE: Burial I

VESSEL NO.: 41MR12-76

NON-PLASTICS: grog

VESSEL FORM: Carinated bowl with a direct rim and a rounded, exterior folded, lip

CORE COLOR: Undetermined

WALL THICKNESS: $5.9 \mathrm{~mm}$

INTERIOR SURFACE TREATMENT: smoothed on rim

EXTERIOR SURFACE TREATMENT: burnished

HEIGHT: $14.5 \mathrm{~cm}$ 
ORIFICE DIAMETER: $24.3 \mathrm{~cm}$

DIAMETER AT BOTTOM OF RIM OR NECK: $23.9 \mathrm{~cm}$

BASE DIAMETER: $7.9 \mathrm{~cm}$

ESTIMATED VOLUME: 3.1 liters

DECORATION: The rim has a pendant triangle engraved motif repeated four times around the vessel, with either diamonds or buttons (within circles) as the central element (Figure 85).

TYPE: Ripley Engraved

Figure 85. Ripley Engraved carinated bowl from Burial I at the Ben McKinney site.

SITE NO.: 41MR12

FEATURE: Burial I

VESSEL NO.: 41MR12-77

NON-PLASTICS: grog and bone

VESSEL FORM: Jar with four peaked rims and four strap handles (under each rim peak). The rim is everted, with a rounded lip.

CORE COLOR: $\mathrm{F}$ (fired in a reducing environment, but cooled in the open air)

WALL THICKNESS: $7.0 \mathrm{~mm}$

INTERIOR SURFACE TREATMENT: smoothed/burnished on the body

EXTERIOR SURFACE TREATMENT: none

HEIGHT: $15.0 \mathrm{~cm}$

ORIFICE DIAMETER: $11.4 \mathrm{~cm}$

DIAMETER AT BOTTOM OF RIM OR NECK: $9.4 \mathrm{~cm}$

BASE DIAMETER: $5.5 \mathrm{~cm}$

ESTIMATED VOLUME: 1.0 liters 
DECORATION: There are closely-spaced vertical incised lines on the rim and strap handles. Above the vertical incised lines is a single row of tool punctations under the lip, and a second row - at the rim-body juncture-below the incised lines (Figure 86). The body has an appliqued decoration consisting of two alternating sets of appliqued diamonds and interlocking scrolls. There is a small appliqued node in the middle of the appliqued diamond element.

TYPE: Harleton Appliqued

Figure 86. Harleton Appliqued jar (MR12-77) from Burial I at the Ben McKinney site.

SITE NO.: 41MR12

FEATURE: Burial III

VESSEL NO.: 41MR12-78

NON-PLASTICS: bone

VESSEL FORM: Jar with an everted rim and a rounded, exterior folded, lip. The rim has four rim peaks, with strap handles attached to the rim under each rim peak.

CORE COLOR: Undetermined

WALL THICKNESS: $7.1 \mathrm{~mm}$

INTERIOR SURFACE TREATMENT: smoothed

EXTERIOR SURFACE TREATMENT: none

HEIGHT: $14.4 \mathrm{~cm}$

ORIFICE DIAMETER: $18.0 \mathrm{~cm}$

DIAMETER AT BOTTOM OF RIM OR NECK: $16.5 \mathrm{~cm}$

BASE DIAMETER: $7.1 \mathrm{~cm}$

ESTIMATED VOLUME: 1.5 liters

DECORATION: The rim and body both have horizontal brushing marks, while the strap handles have vertical appliqued fillets (Figure 87). There are four sets of two nodes (one above the other) also on the rim but between each of the strap handles. In addition to the 
brushing on the vessel body, there are four panels defined by three vertical appliqued

fillets. Within each of the panels are five semi-circular appliqued fillets (see Figure 87).

TYPE: Harleton Appliqued

Figure 87. Harleton Appliqued jar from Burial III at the Ben McKinney site.

SITE NO.: 41MR12

FEATURE: Burial III

VESSEL NO.: 41MR12-79

NON-PLASTICS: grog and charred organic materials

VESSEL FORM: Carinated bowl with a direct rim and a rounded, exterior folded, lip

CORE COLOR: Undetermined

WALL THICKNESS: $8.6 \mathrm{~mm}$

INTERIOR SURFACE TREATMENT: smoothed

EXTERIOR SURFACE TREATMENT: burnished

HEIGHT: $11.0 \mathrm{~cm}$

ORIFICE DIAMETER: $24.2 \mathrm{~cm}$

DIAMETER AT BOTTOM OF RIM OR NECK: $23.0 \mathrm{~cm}$

BASE DIAMETER: $10.6 \mathrm{~cm}$

ESTIMATED VOLUME: 1.6 liters

DECORATION: Engraved horizontal scroll motif repeated four times on the rim. Each of the scroll motifs are divided by vertical opposed engraved arcs (Figure 88).

TYPE: Ripley Engraved

Figure 88. Ripley Engraved carinated bowl from Burial III at the Ben McKinney site. 
SITE NO.: 41MR12

FEATURE: Burial II

VESSEL NO.: 41MR12-80

NON-PLASTICS: grog, bone, and hematite

VESSEL FORM: Carinated bowl with a direct rim and a rounded lip

CORE COLOR: $\mathrm{H}$ (fired in a reducing environment and cooled in the open air)

WALL THICKNESS: $6.4 \mathrm{~mm}$

INTERIOR SURFACE TREATMENT: smoothed only on the lower body

EXTERIOR SURFACE TREATMENT: burnished

HEIGHT: $13.2 \mathrm{~cm}$

ORIFICE DIAMETER: $24.4 \mathrm{~cm}$

DIAMETER AT BOTTOM OF RIM OR NECK: $24.0 \mathrm{~cm}$

BASE DIAMETER: $8.0 \mathrm{~cm}$

ESTIMATED VOLUME: 2.9 liters

DECORATION: The pendant triangle motif is repeated four times around the circumference of the vessel (Figure 89). The central element in the motif is an engraved circle or button with an excised diamond-shaped area at the central part of the circle or button.

TYPE: Ripley Engraved

Figure 89. Ripley Engraved carinated bowl (MR12-80) from Burial II at the Ben McKinney site.

SITE NO.: 41MR12

FEATURE: Burial I

VESSEL NO.: 41MR12-81 
NON-PLASTICS: grog-bone

VESSEL FORM: Jar with an everted rim and a rounded lip

CORE COLOR: Undetermined

WALL THICKNESS: $7.7 \mathrm{~mm}$

INTERIOR SURFACE TREATMENT: smoothed

EXTERIOR SURFACE TREATMENT: none

HEIGHT: $22.5 \mathrm{~cm}$

ORIFICE DIAMETER: $21.5 \mathrm{~cm}$

DIAMETER AT BOTTOM OF RIM OR NECK: $19.1 \mathrm{~cm}$

BASE DIAMETER: $6.5 \mathrm{~cm}$

ESTIMATED VOLUME: 4.3 liters

DECORATION: There are eight closely-spaced rows of tool punctations on the vessel rim and overlapping-horizontal brushing marks on the vessel body (Figure 90).

TYPE: Undetermined decorated utility ware

Figure 90. Brushed-punctated jar (MR12-81) from Burial I at the Ben McKinney site.

SITE NO.: 41MR12

FEATURE: Burial II

VESSEL NO.: 41MR12-102

NON-PLASTICS: grog

VESSEL FORM: Bottle with a short direct neck (or a small olla) (Figure 91) and a rounded, exterior folded lip

CORE COLOR: Undetermined

WALL THICKNESS: Undetermined 
INTERIOR SURFACE TREATMENT: smoothed on the neck

EXTERIOR SURFACE TREATMENT: smoothed and red-slipped

HEIGHT: $16.0 \mathrm{~cm}$

ORIFICE DIAMETER: $6.2 \mathrm{~cm}$

DIAMETER AT BOTTOM OF RIM OR NECK: $6.4 \mathrm{~cm}$

BASE DIAMETER: $6.6 \mathrm{~cm}$

ESTIMATED VOLUME: 0.4 liters

DECORATION: Four sets of large engraved circles divided by two semi-circular vertical engraved lines on either side of the large circles. Each circle is composed of eight lines (Figure 91).

TYPE: Taylor Engraved?

Figure 91. Engraved and red-slipped bottle or olla from Burial II at the Ben McKinney site.

SITE NO.: 41MR12

FEATURE: Burial II

VESSEL NO.: 41MR12-103

NON-PLASTICS: grog-bone

VESSEL FORM: Jar; the rim is missing

CORE COLOR: B (fired and cooled in a reducing environment)

WALL THICKNESS: $5.7 \mathrm{~mm}$

INTERIOR SURFACE TREATMENT: smoothed

EXTERIOR SURFACE TREATMENT: none

HEIGHT: Undetermined

ORIFICE DIAMETER: $16.0 \mathrm{~cm}$ 


\section{DIAMETER AT BOTTOM OF RIM OR NECK: N/A}

BASE DIAMETER: $7.0 \mathrm{~cm}$

ESTIMATED VOLUME: Undetermined

DECORATION: The vessel body has an appliqued design consisting of alternating diamonds and hooked arm scrolls. Within each appliqued diamond is a small punctated appliqued circle (Figure 92).

TYPE: Harleton Appliqued

Figure 92. Harleton Appliqued jar (MR12-103) from Burial II at the Ben McKinney site.

SITE NO.: 41MR12

FEATURE: Burial II

VESSEL NO.: 41MR12-104

NON-PLASTICS: grog

VESSEL FORM: Jar with a direct to slightly everted rim and a rounded, exterior folded, lip. There are four rim peaks and four strap handles, each strap handle placed under the rim peaks (Figure 93).

CORE COLOR: A (fired and cooled in an oxidizing environment)

WALL THICKNESS: $7.5 \mathrm{~mm}$

INTERIOR SURFACE TREATMENT: smoothed

EXTERIOR SURFACE TREATMENT: none

HEIGHT: $17.3 \mathrm{~cm}$

ORIFICE DIAMETER: $15.5 \mathrm{~cm}$

DIAMETER AT BOTTOM OF RIM OR NECK: $14.9 \mathrm{~cm}$

BASE DIAMETER: $7.0 \mathrm{~cm}$

ESTIMATED VOLUME: 2.4 liters 
DECORATION: The rim is decorated with vertical incised lines; the small strap handles are plain (Figure 93). The vessel body has an appliqued design that includes repeated and alternating sets of appliqued circles and triangles. Within each circle is a single short appliqued ridge. The appliqued triangles (set between the appliqued circles) have two opposed sets of appliqued ridges and a single vertical appliqued ridge.

TYPE: Harleton Appliqued

Figure 93. Harleton Appliqued jar from Burial II at the Ben McKinney site.

SITE NO.: 41MR12

FEATURE: Burial I

VESSEL NO.: 41MR12-105

NON-PLASTICS: grog

VESSEL FORM: Carinated bowl with a direct rim and a rounded lip

CORE COLOR: $\mathrm{F}$ (fired in a reducing environment and cooled in the open air)

WALL THICKNESS: $6.5 \mathrm{~mm}$

INTERIOR SURFACE TREATMENT: smoothed

EXTERIOR SURFACE TREATMENT: burnished

HEIGHT: $14.5 \mathrm{~cm}$

ORIFICE DIAMETER: $23.9 \mathrm{~cm}$

DIAMETER AT BOTTOM OF RIM OR NECK: $23.5 \mathrm{~cm}$

BASE DIAMETER: $6.5 \mathrm{~cm}$

ESTIMATED VOLUME: 3.1 liters

DECORATION: The rim has a scroll and nested triangle engraved motif that is repeated four times around the rim (Figure 94a-b). This motif includes a central circle element between diagonal scrolls (forming a nested triangle between the engraved circles) with small excised pendant triangles. Three of the central circles are defined by two lines, with the fourth has a smaller circle within the larger outer circle, and the smaller circle has 
intersecting engraved lines within it (i.e., a cross motif, see Figure 94b). There are also hatched engraved zones above and below the scrolls.

TYPE: Ripley Engraved

Figure 94. Ripley Engraved carinated bowl (MR12-105) from Burial I at the Ben McKinney site: a, photograph; b, drawing by Bobby Gonzalez.

SITE NO.: 41MR12

FEATURE: Burial I

VESSEL NO.: 41MR12-113

NON-PLASTICS: grog-hematite

VESSEL FORM: Olla with a short, direct, and wide neck with a rounded lip

CORE COLOR: A (fired and cooled in an oxidizing environment)

WALL THICKNESS: $6.7 \mathrm{~mm}$

INTERIOR SURFACE TREATMENT: none

EXTERIOR SURFACE TREATMENT: smoothed

HEIGHT: $19.8 \mathrm{~cm}$

ORIFICE DIAMETER: $8.4 \mathrm{~cm}$ at the neck

DIAMETER AT BOTTOM OF RIM OR NECK: $8.2 \mathrm{~cm}$

BASE DIAMETER: $7.5 \mathrm{~cm}$

ESTIMATED VOLUME: 1.2 liters

DECORATION: There are four arcs of engraved semi-circles on the vessel body. Each arc is comprised of 20 semi-circles (Figure 95).

TYPE: Taylor Engraved

Figure 95. Taylor Engraved olla from Burial I (MR12-113) at the Ben McKinney site. 


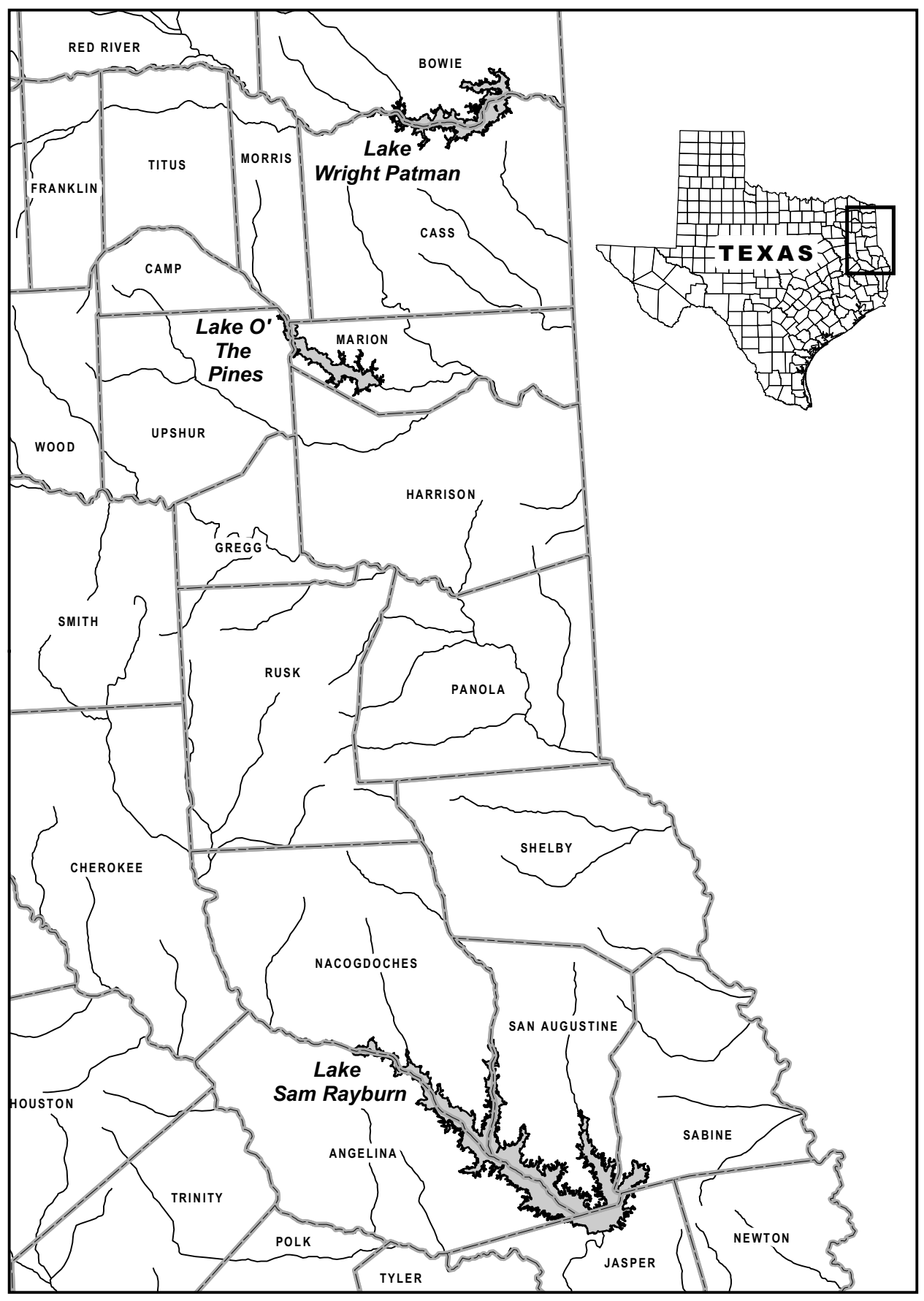

Figure 1 


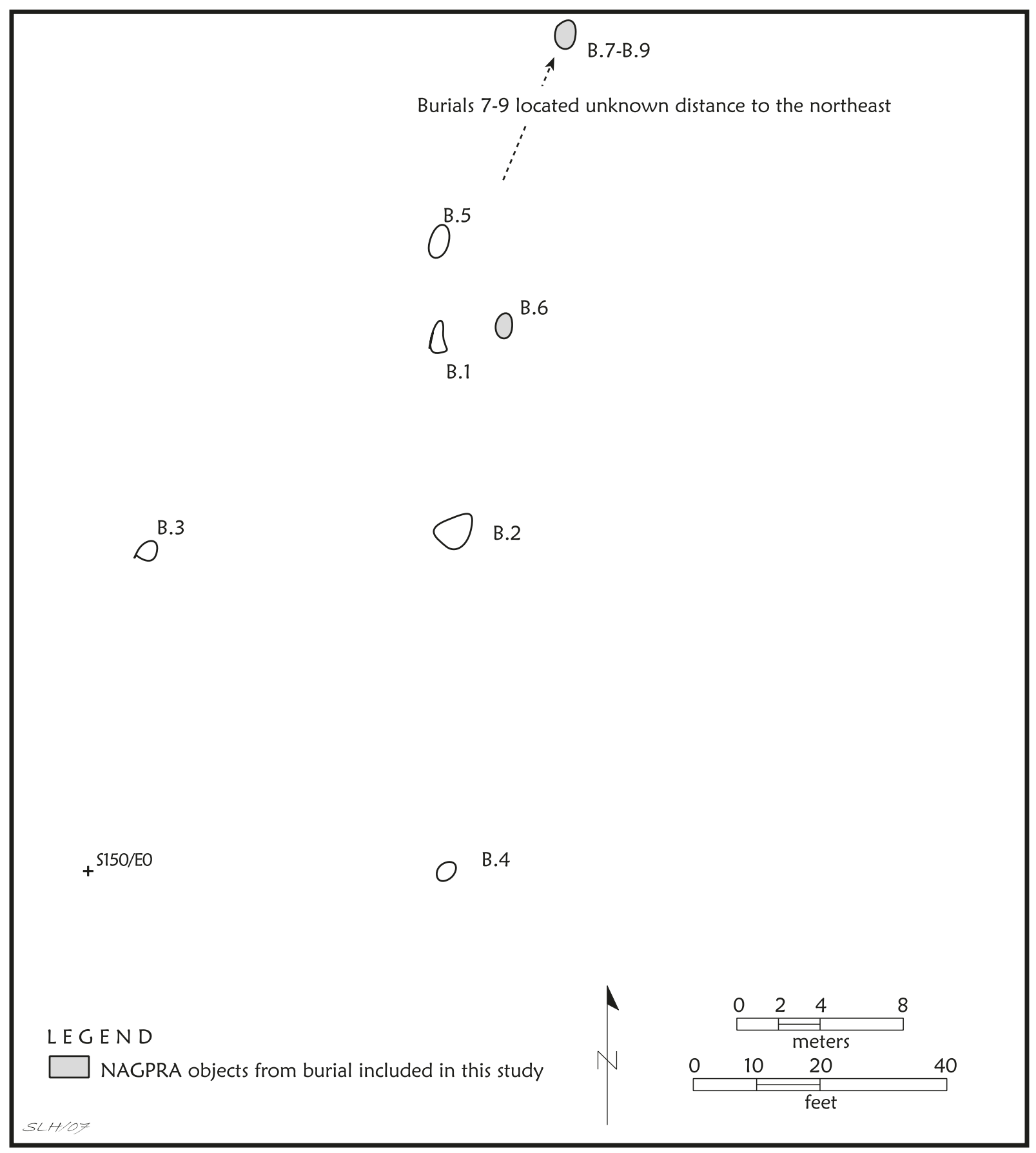

Figure 2 


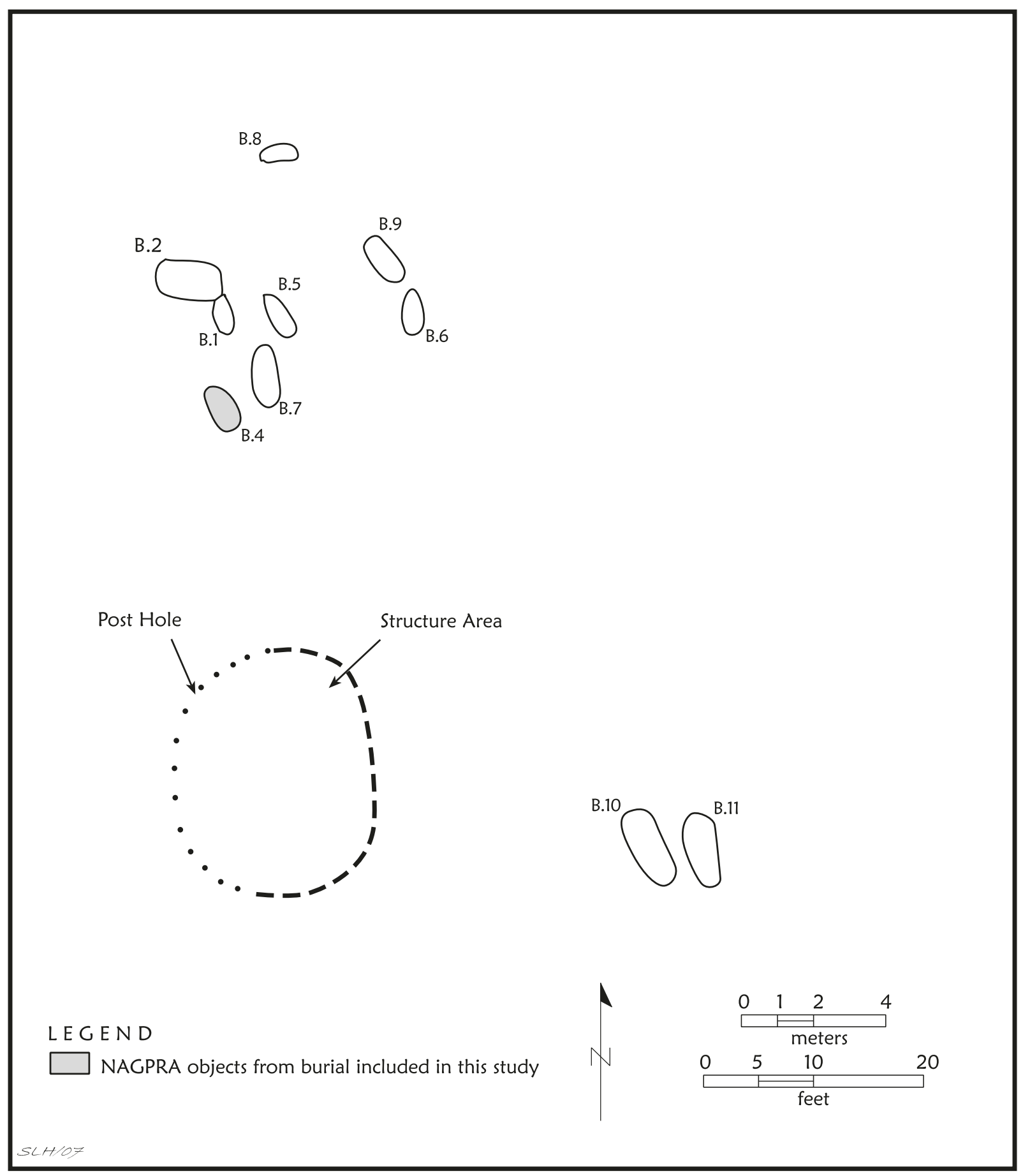

Figure 4 


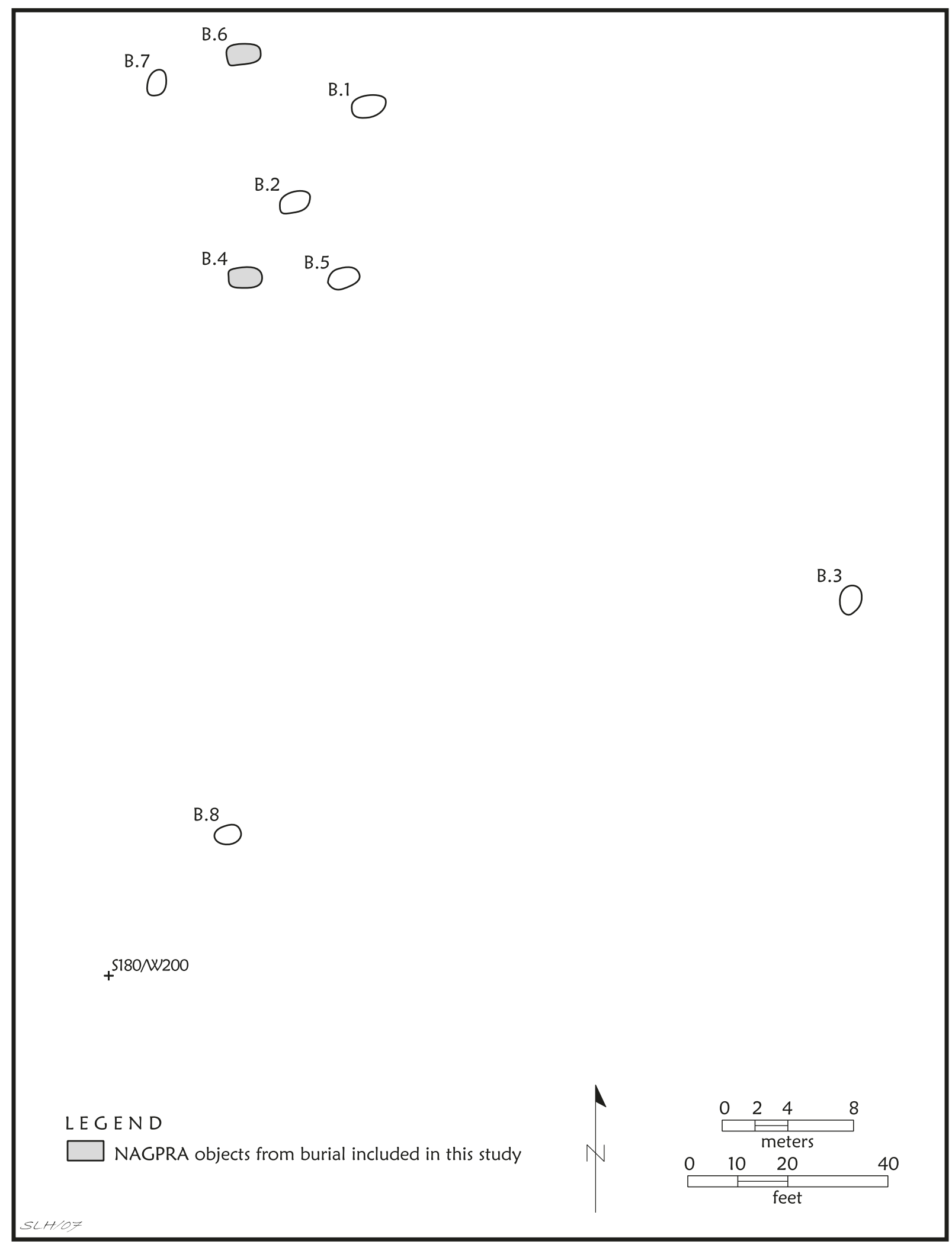

Figure 6 


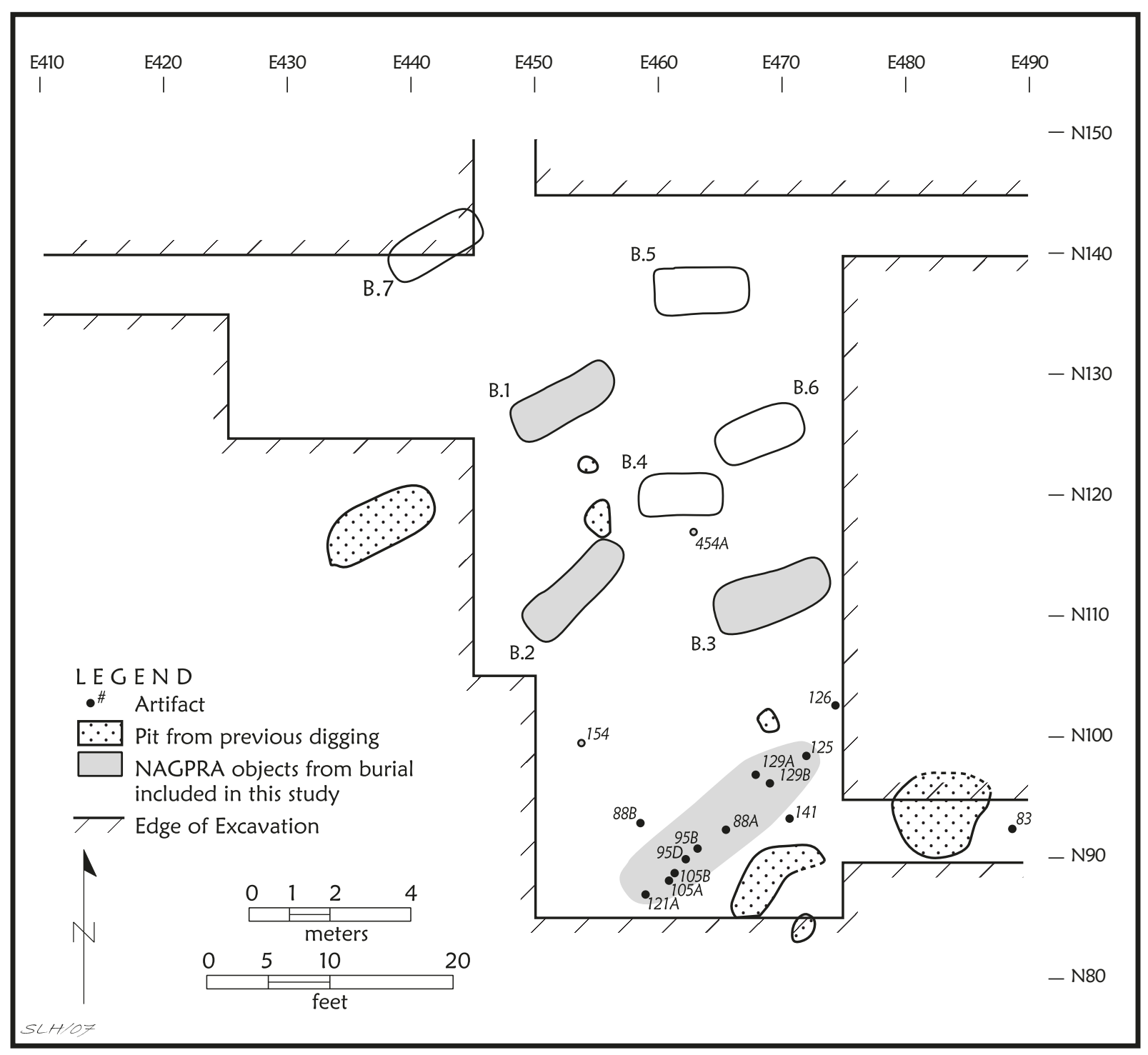

Figure 8 


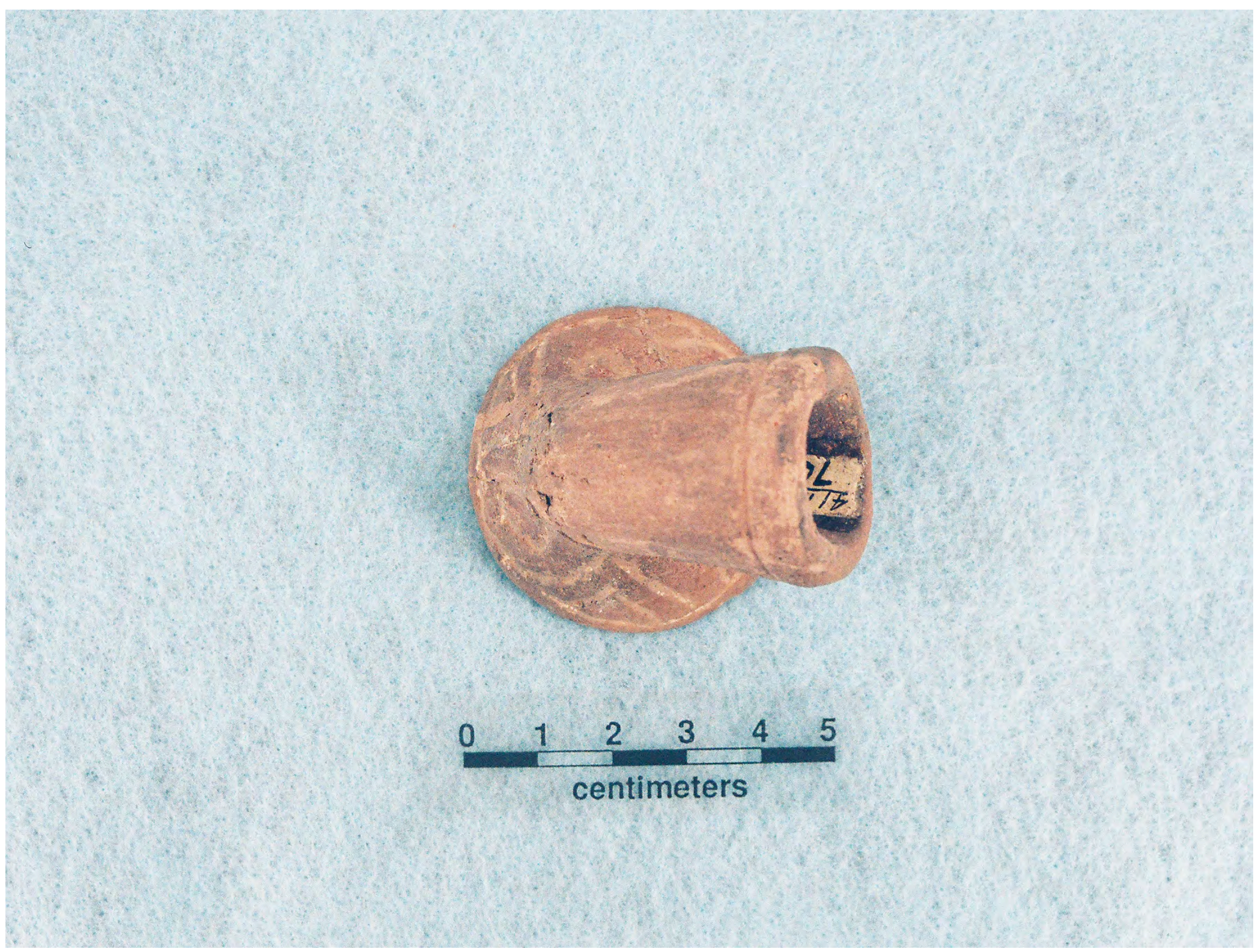

Figure 13a 


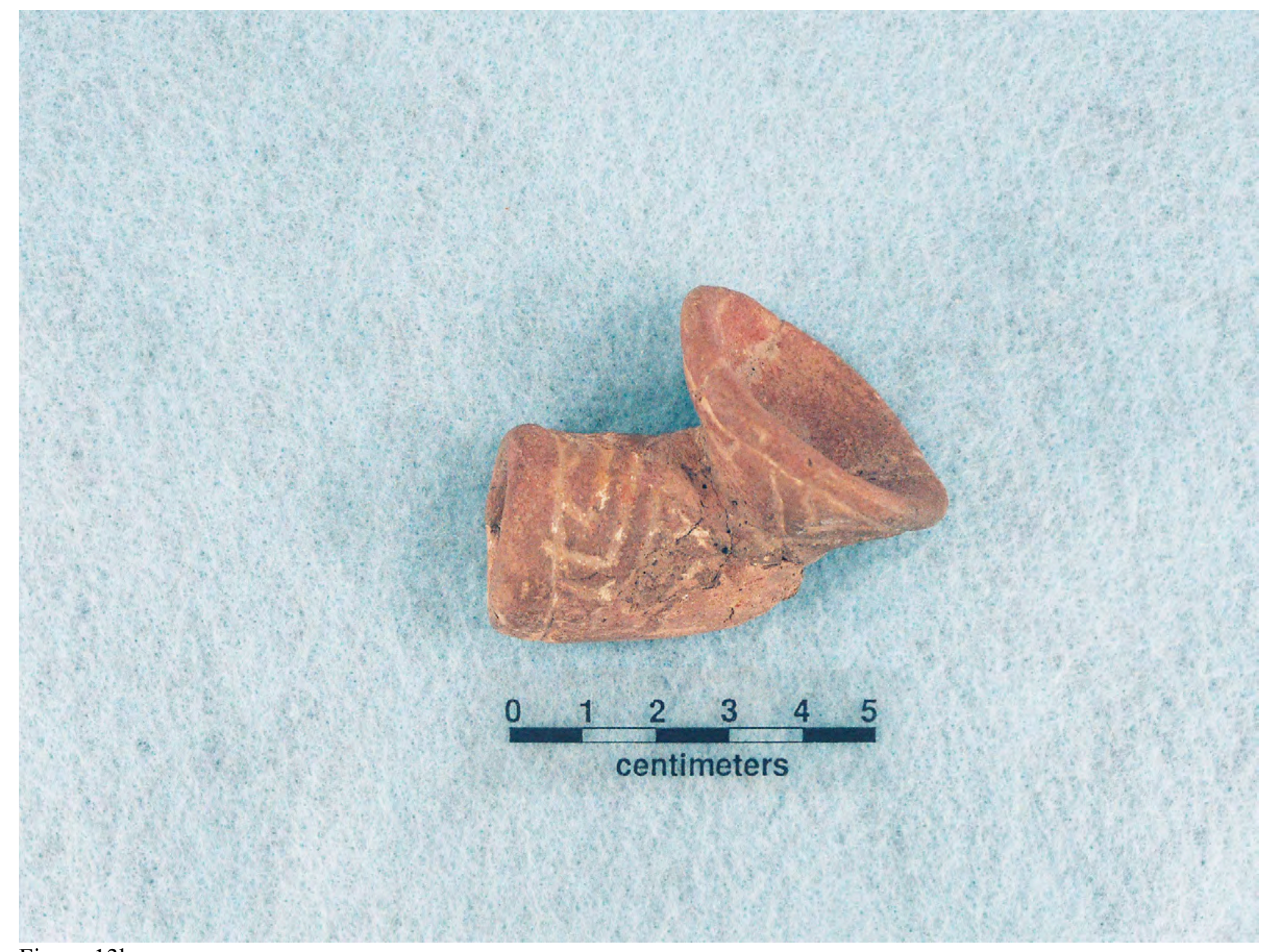

Figure $13 b$ 


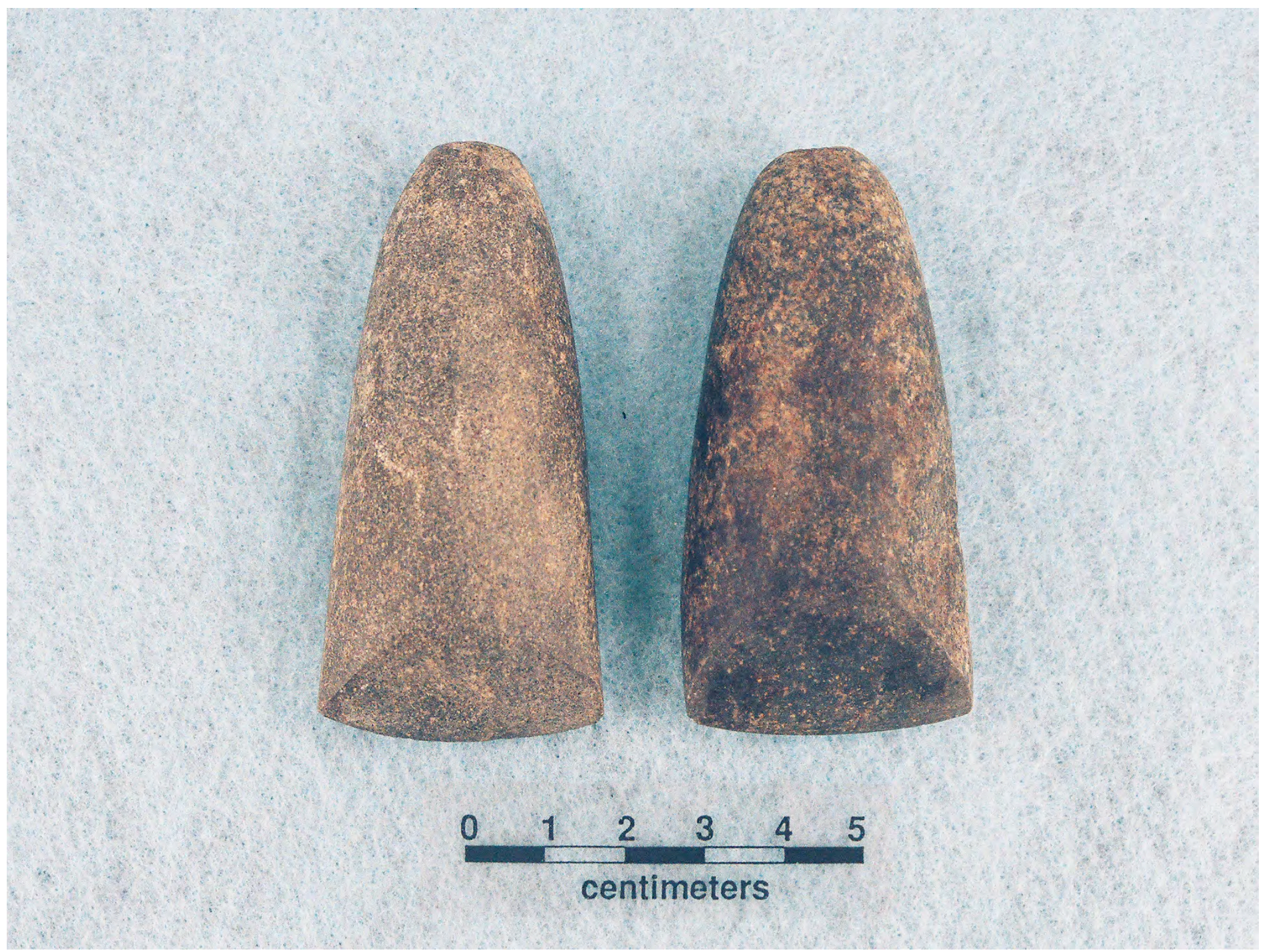

Figure 14 


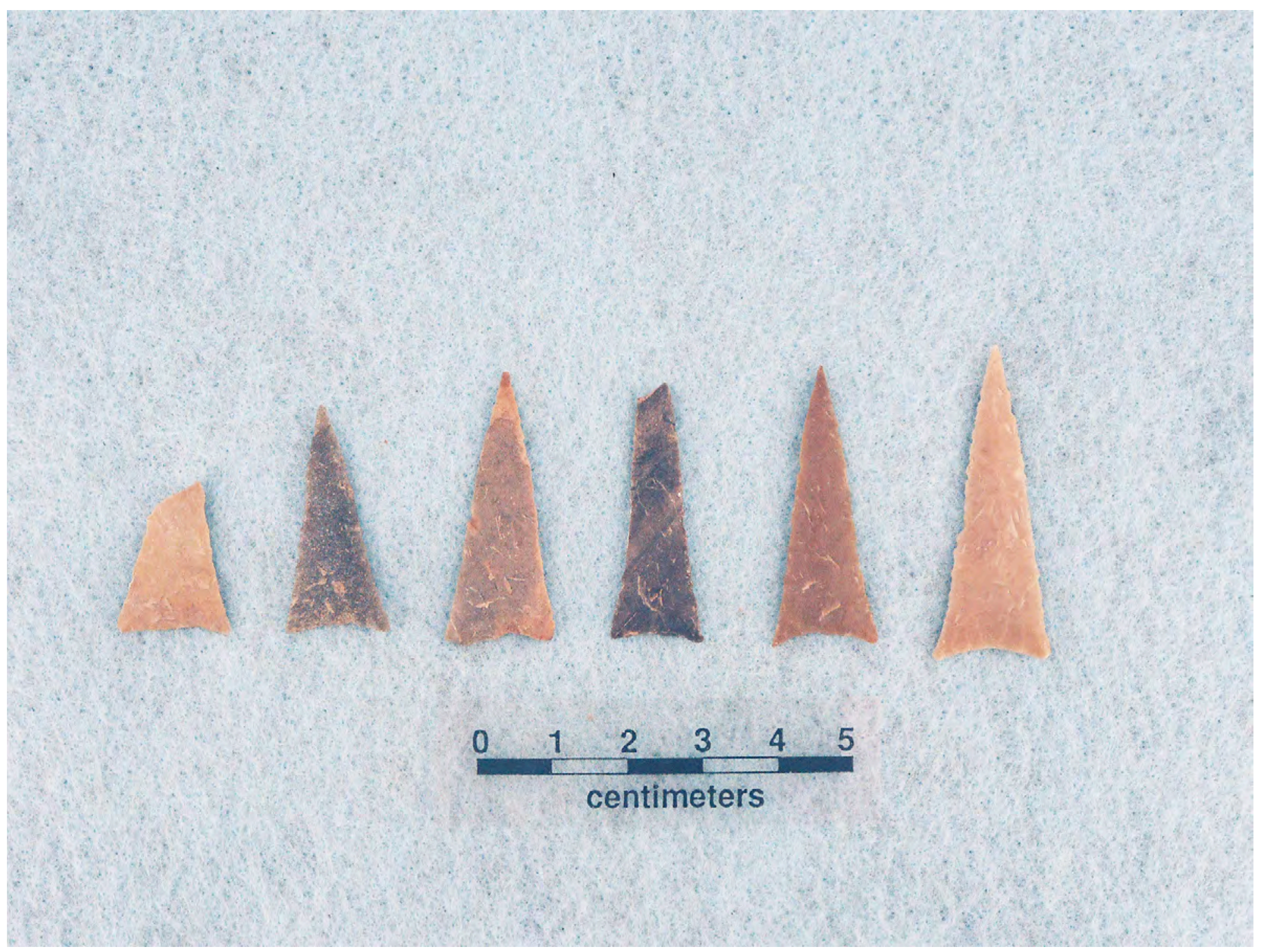

Figure 15 


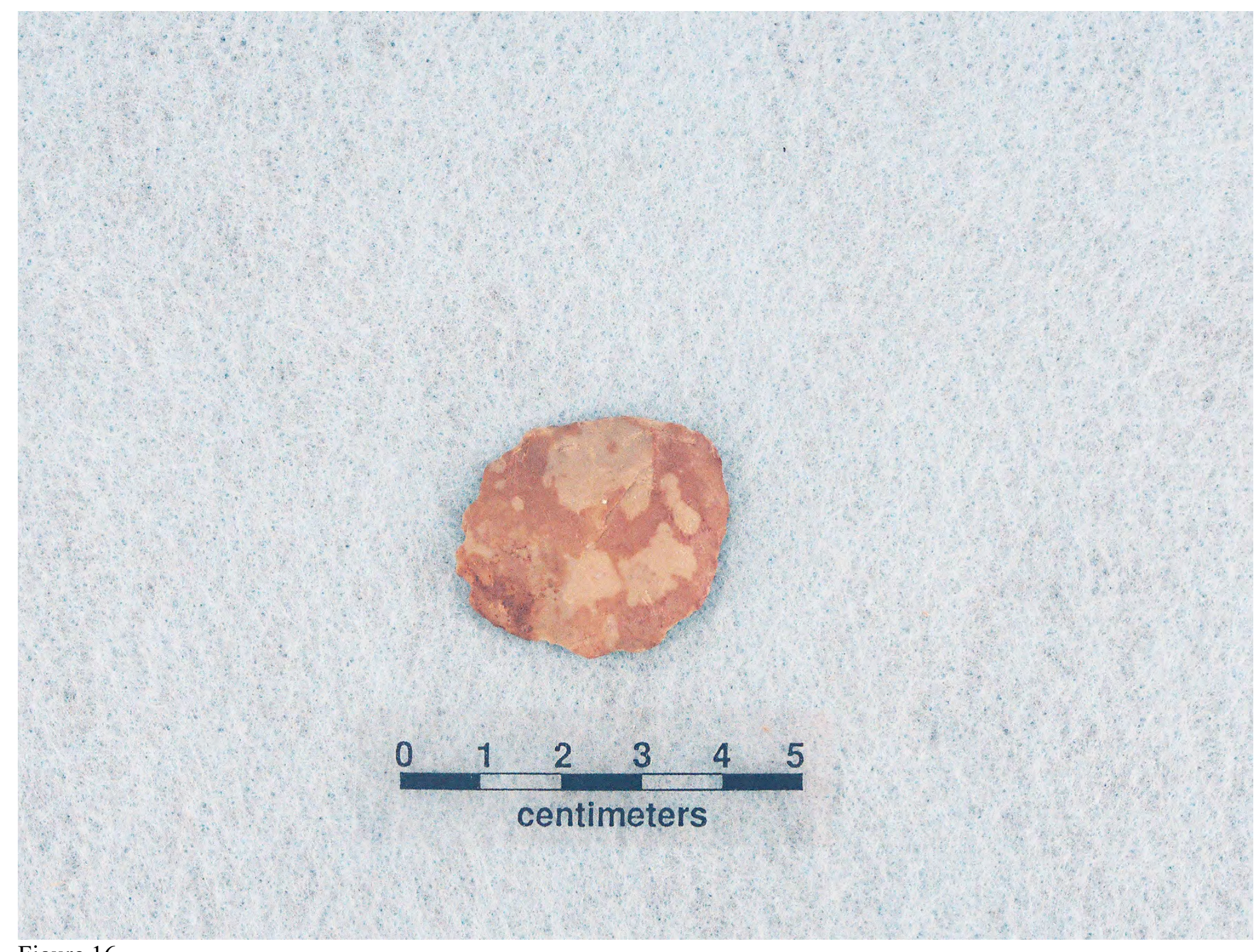

Figure 16 

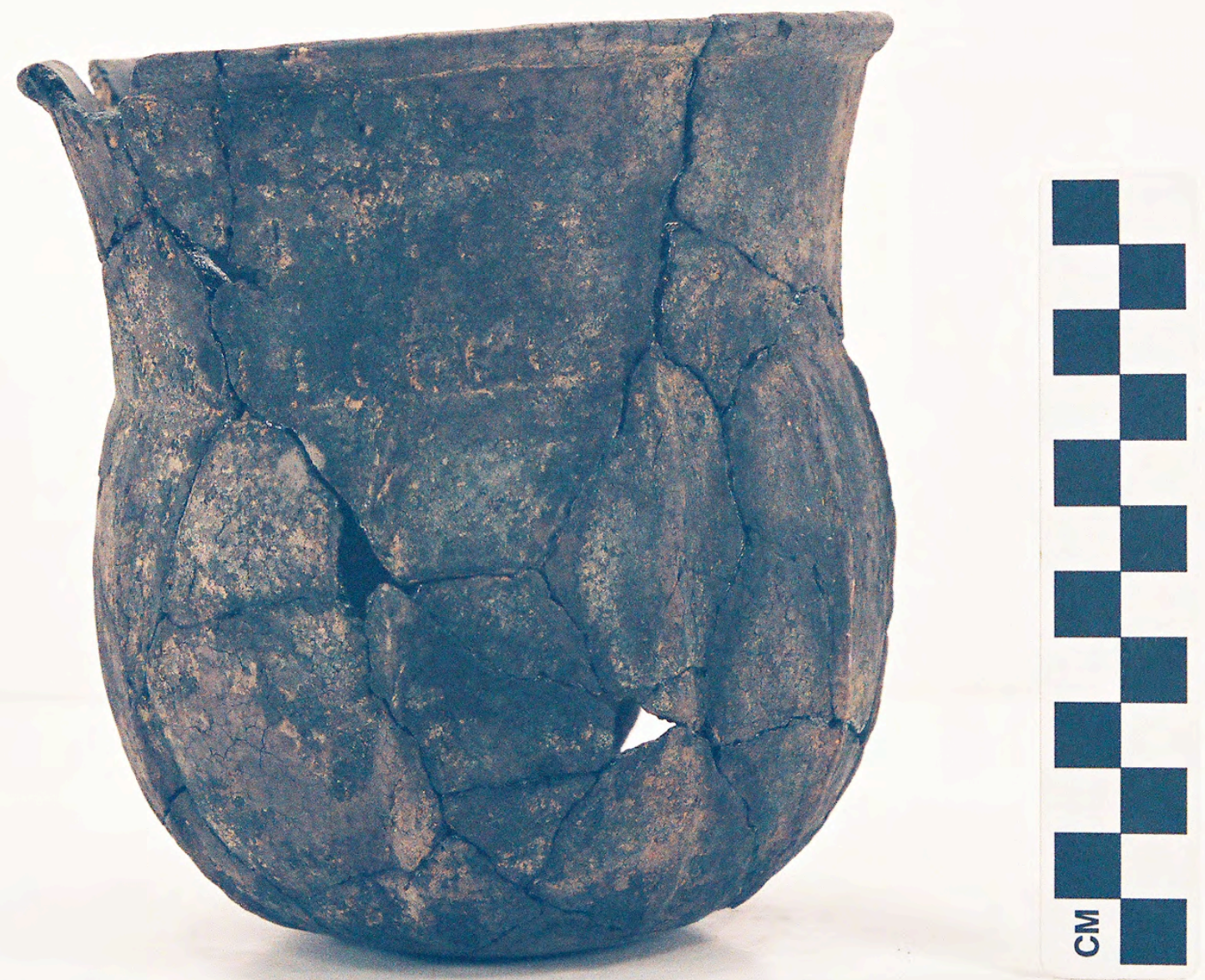

Figure 17a 


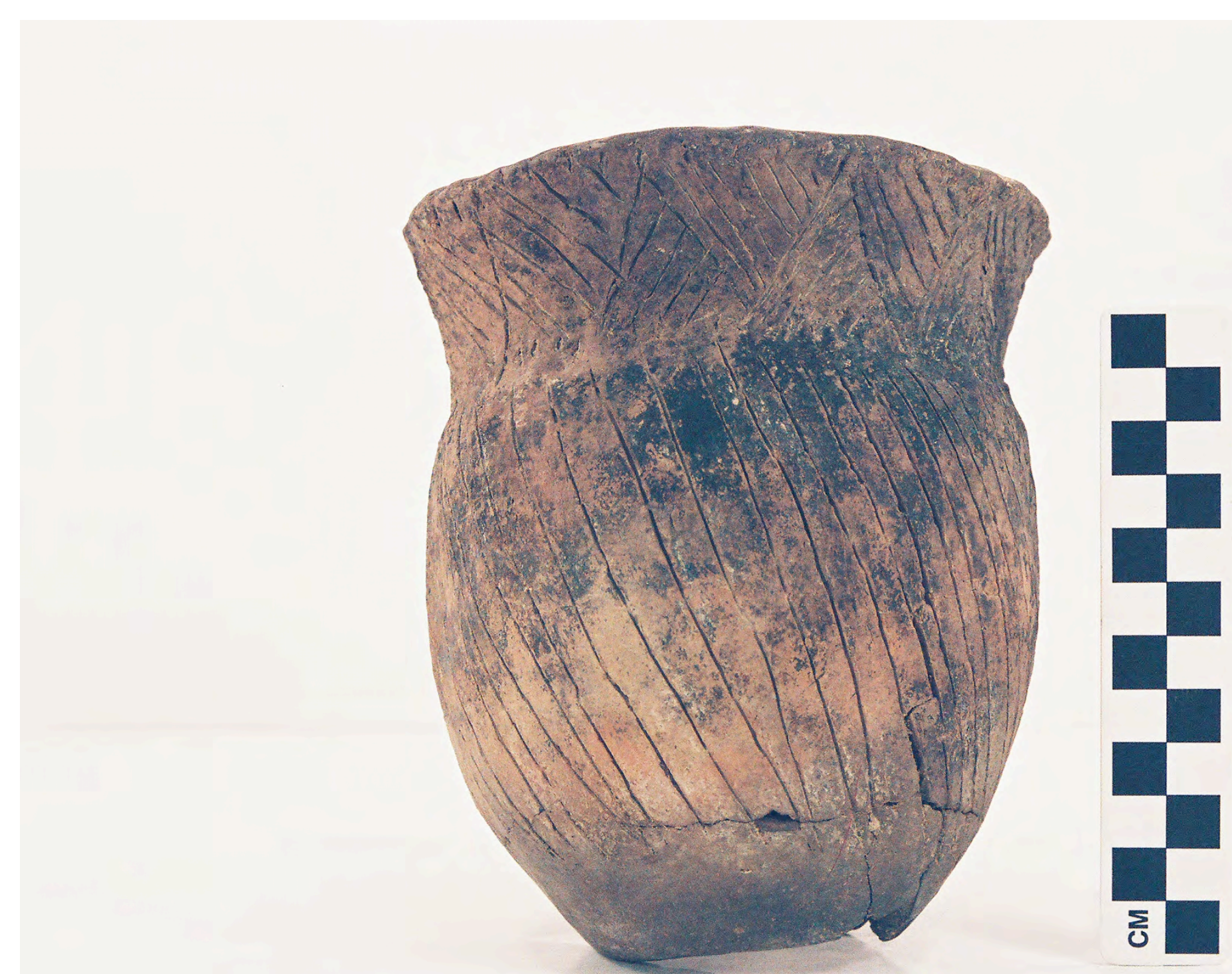

Figure $17 \mathrm{~b}$ 


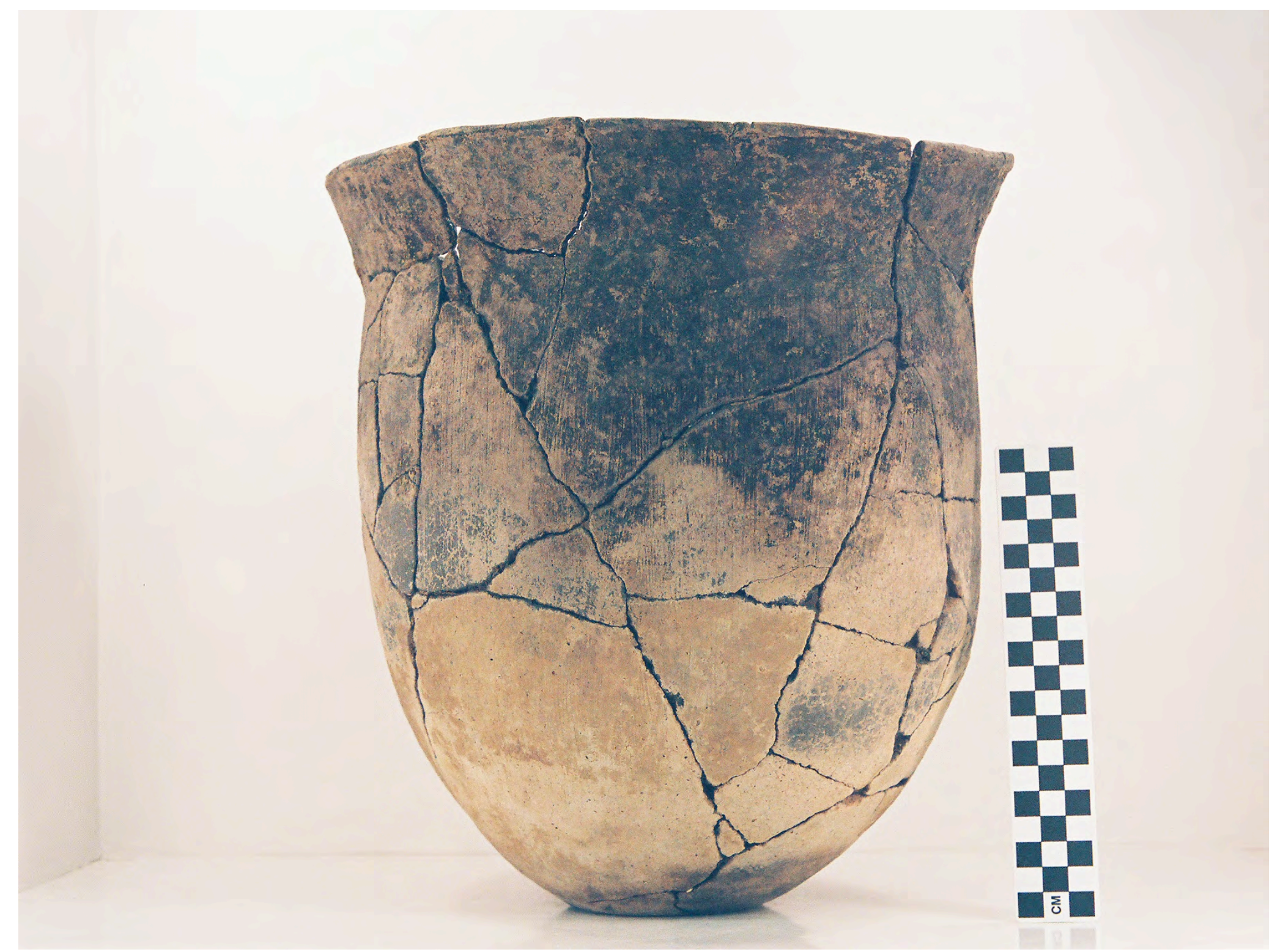

Figure 17c 


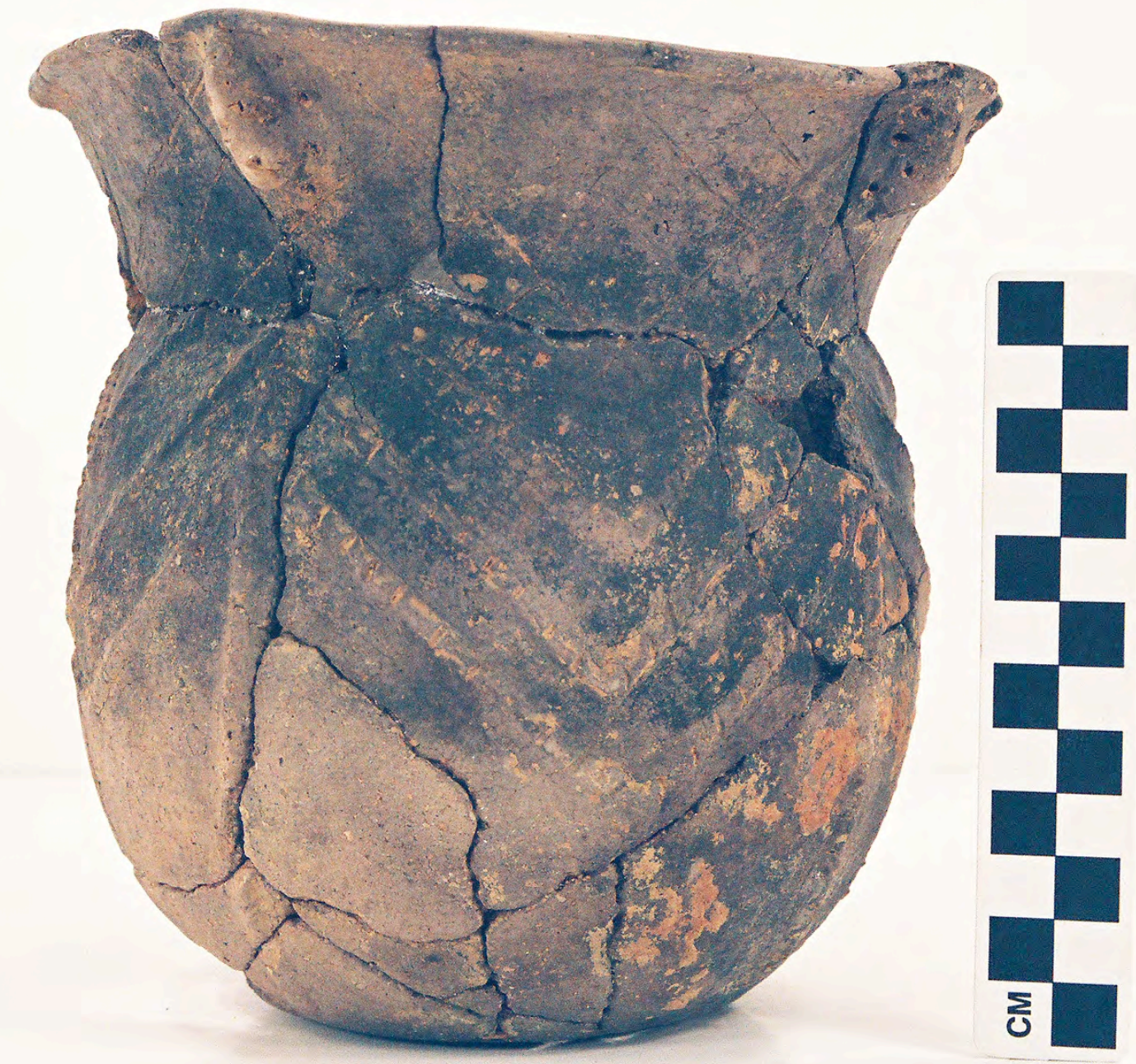

Figure 17d 


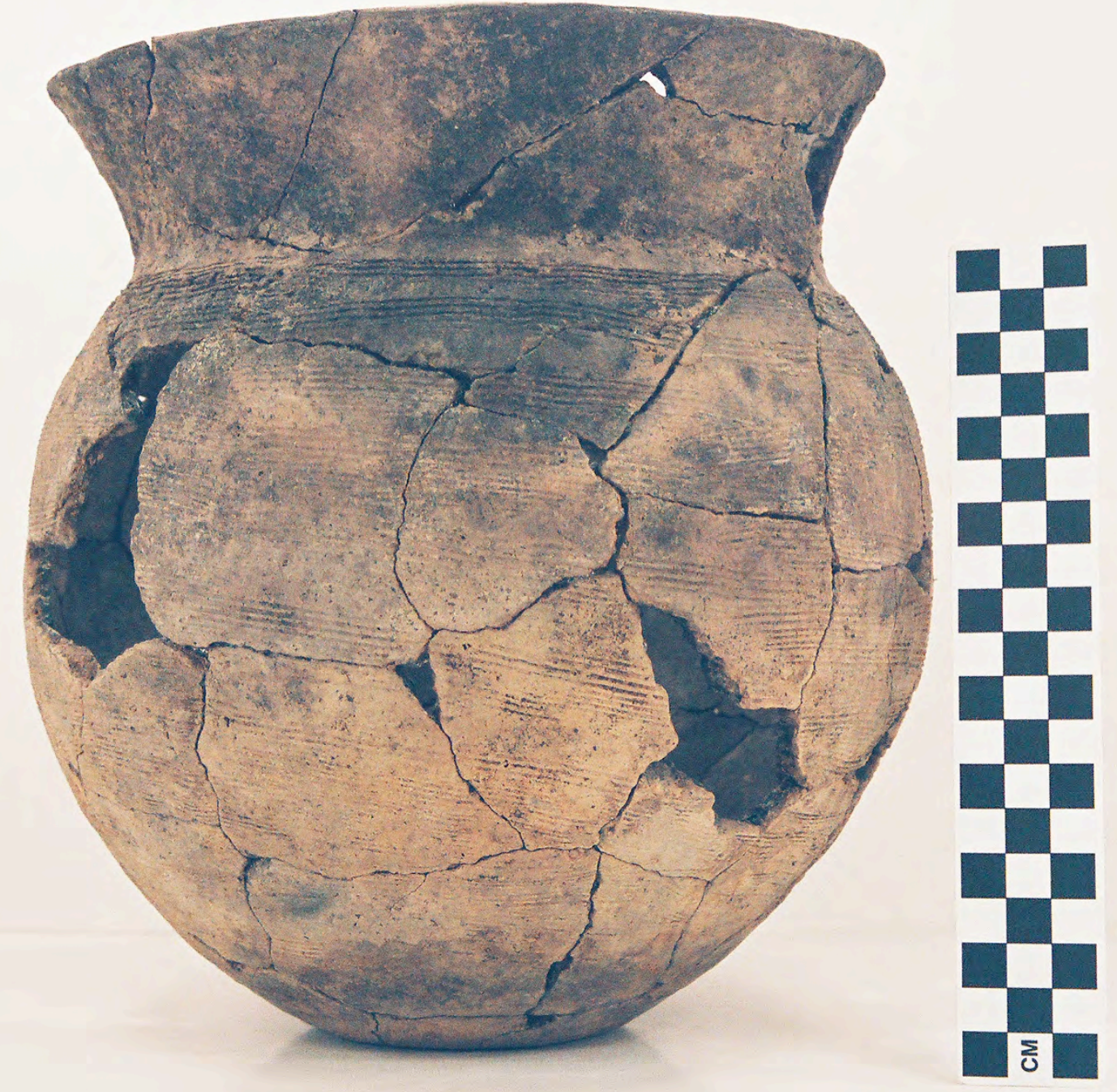

Figure $17 \mathrm{e}$ 


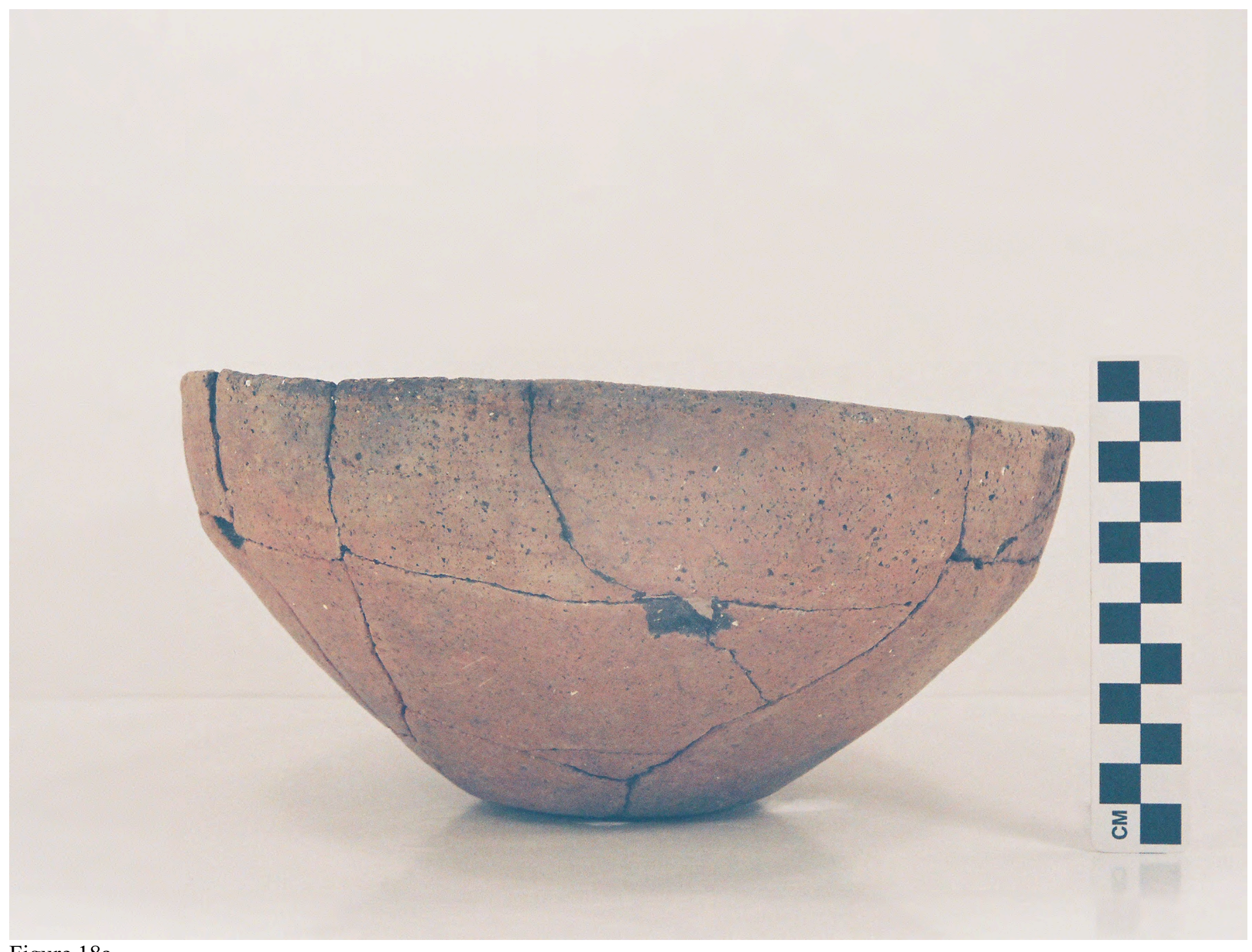

Figure 18a 

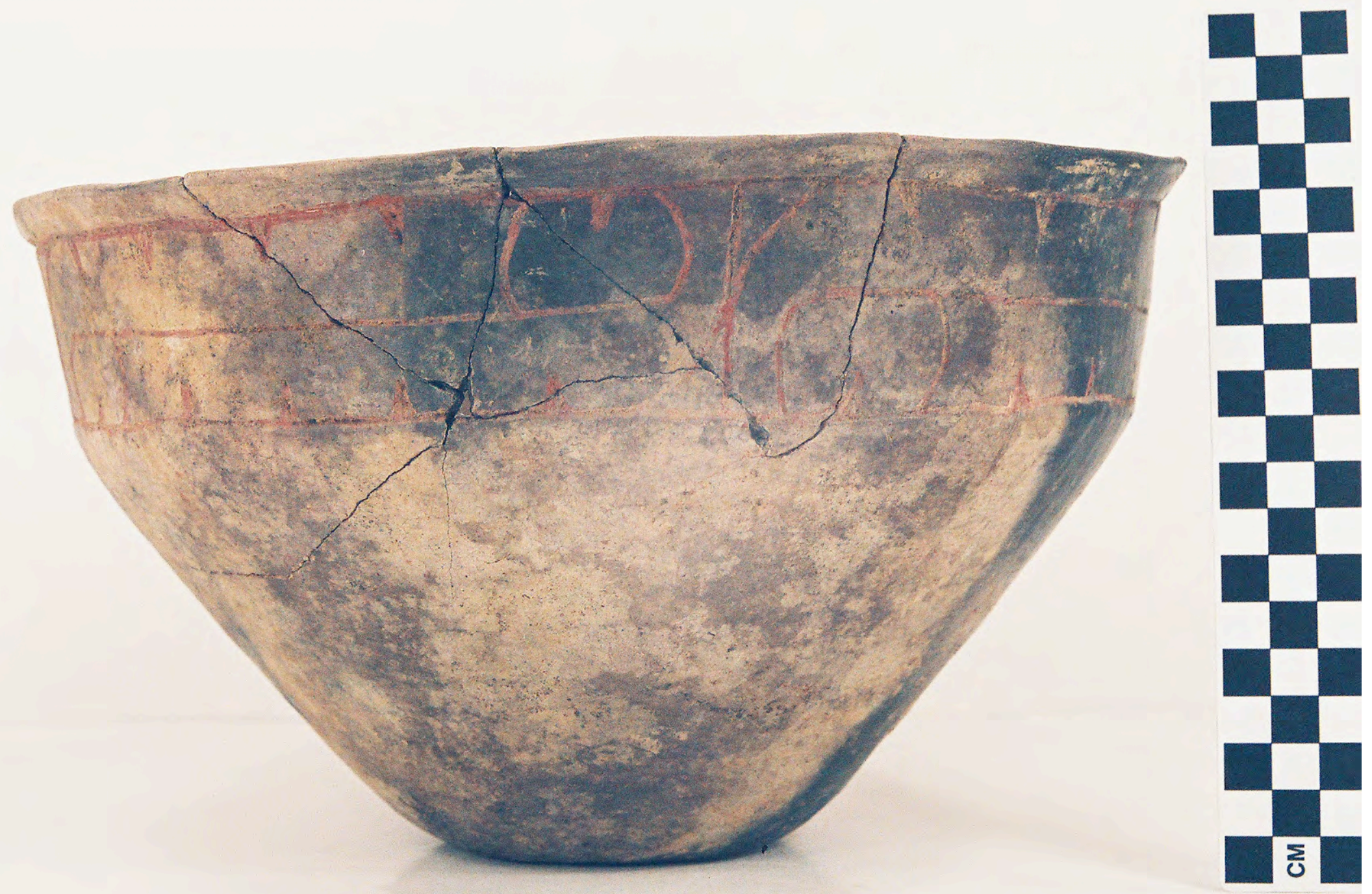

Figure 18b 

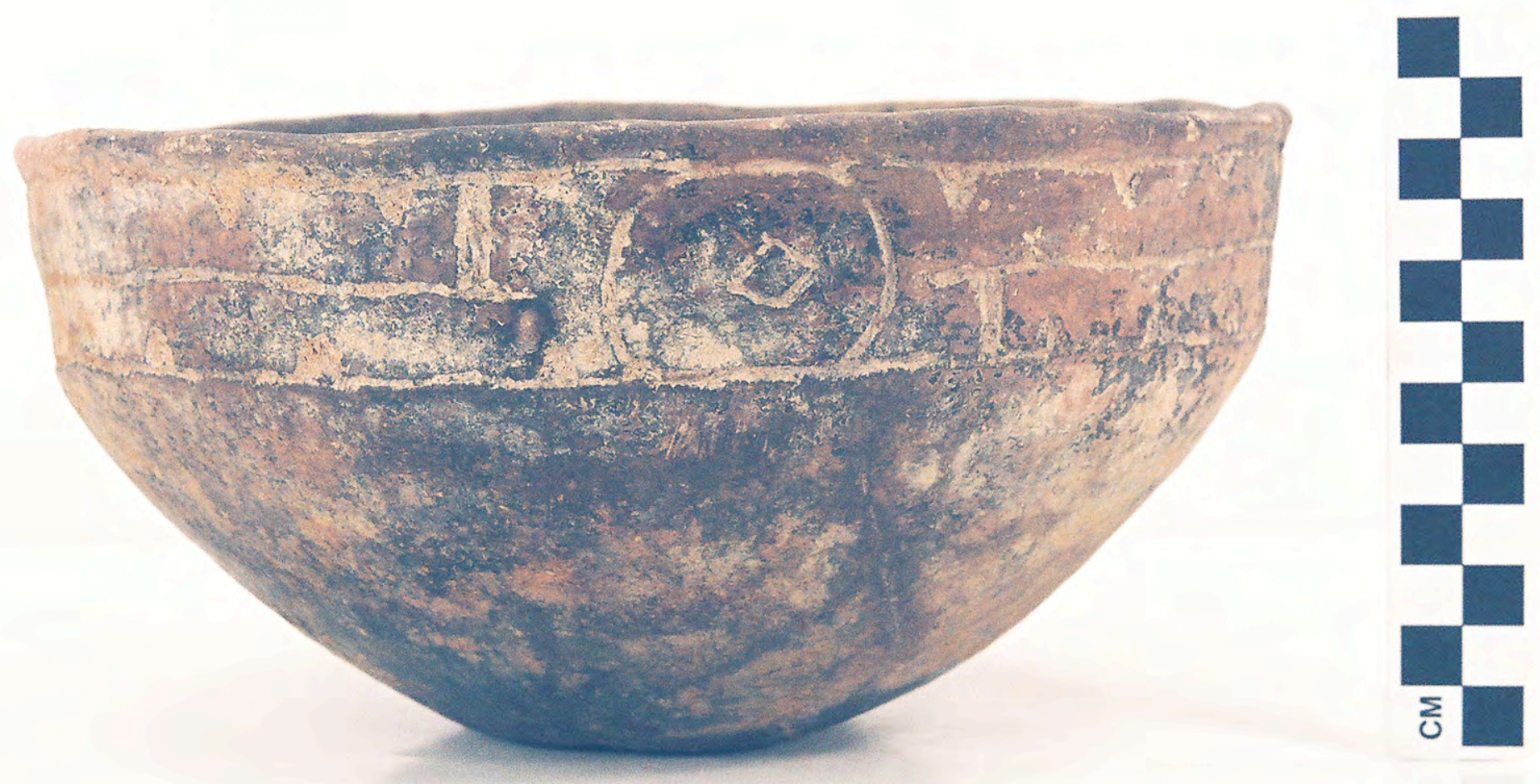

Figure 18c 

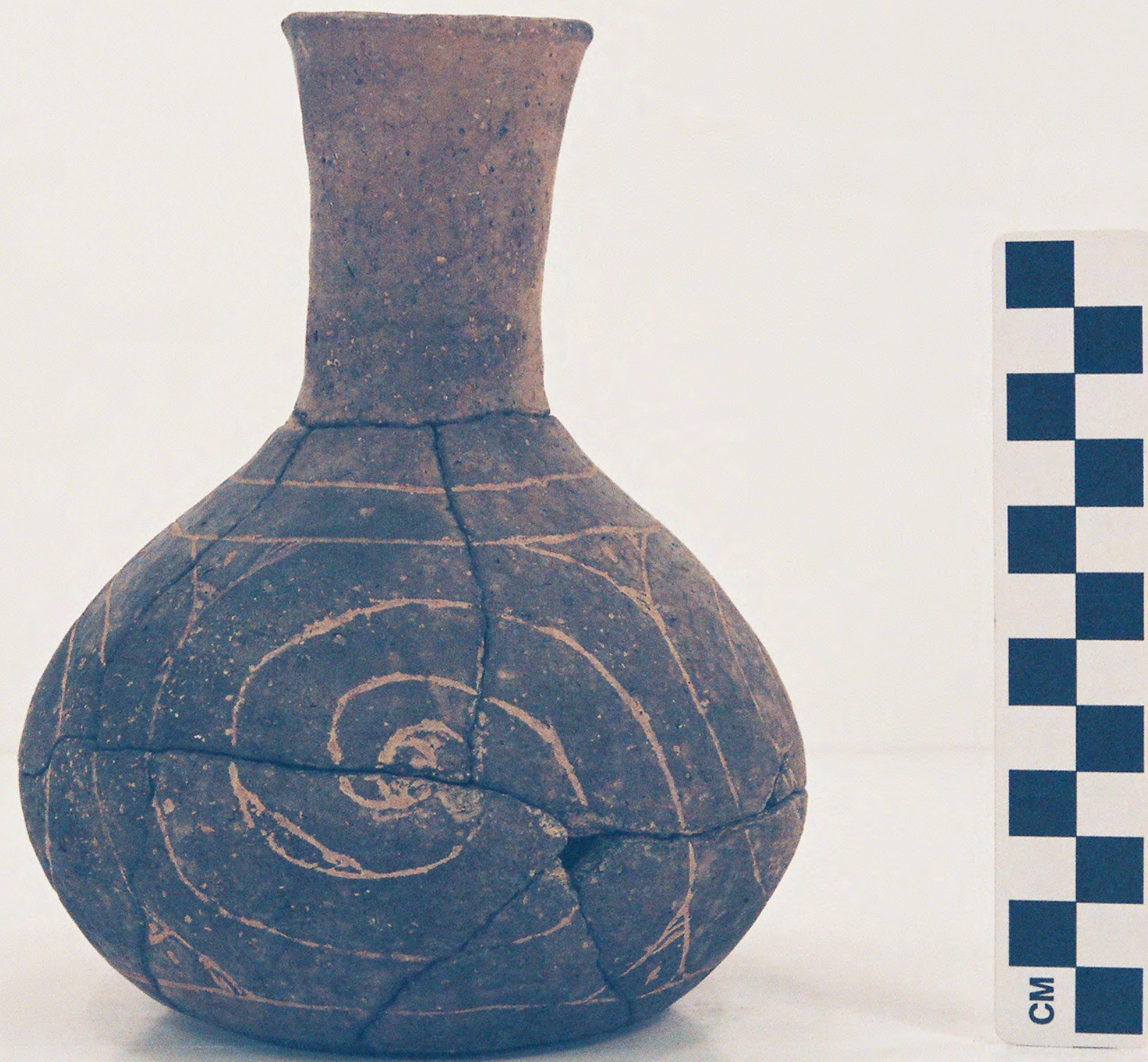

Figure 19a 


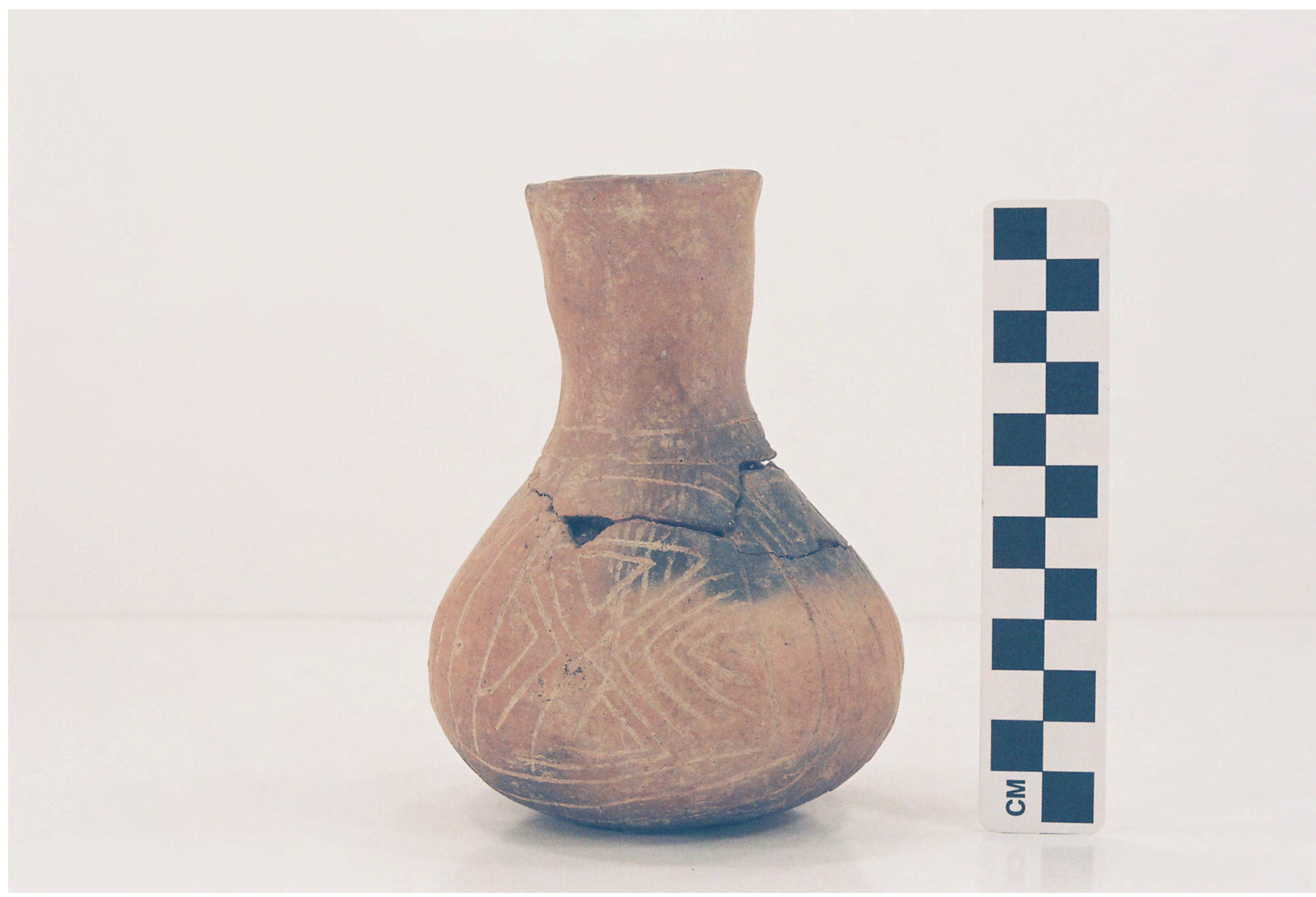

Figure 19b 


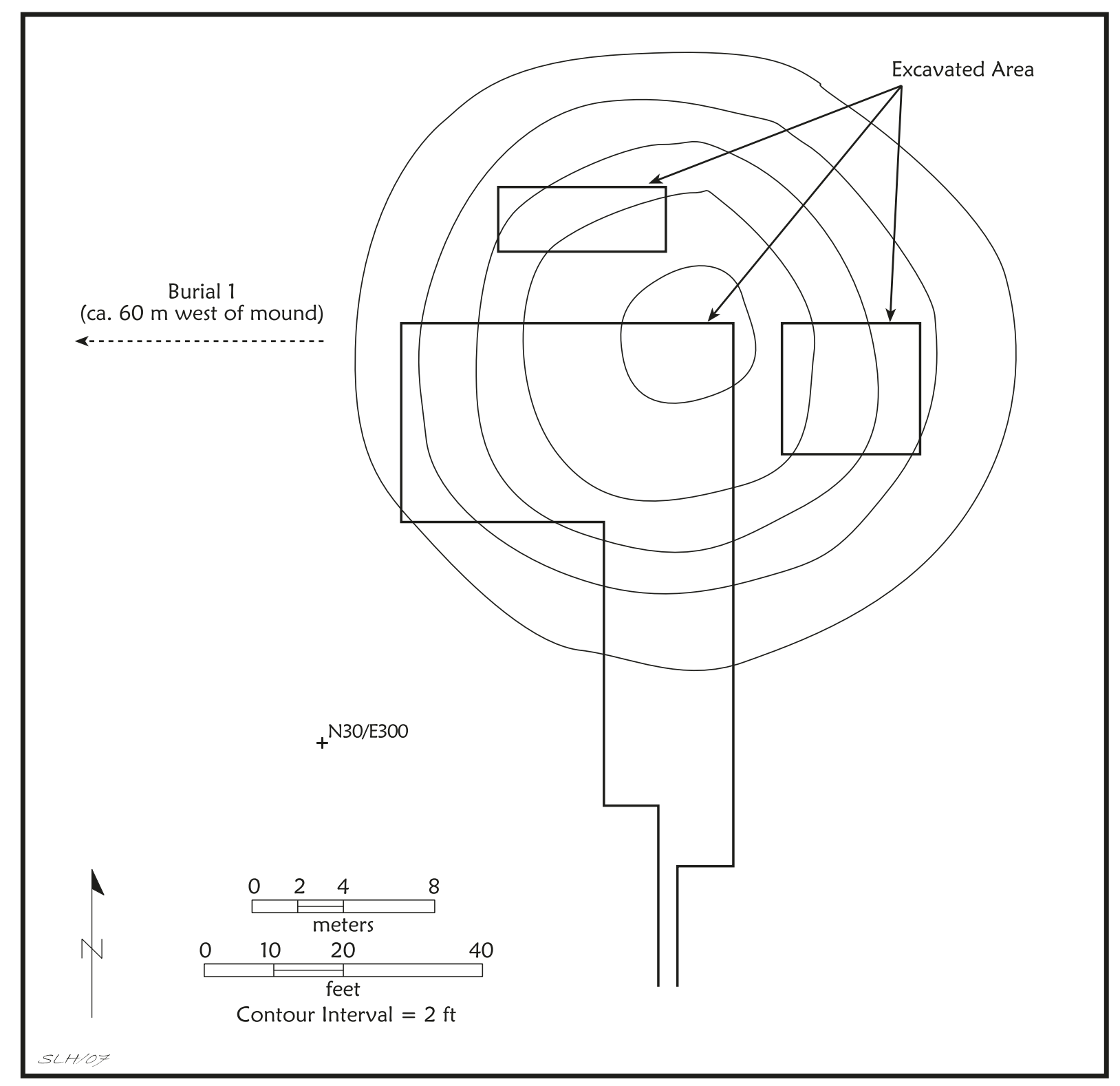

Figure 20 


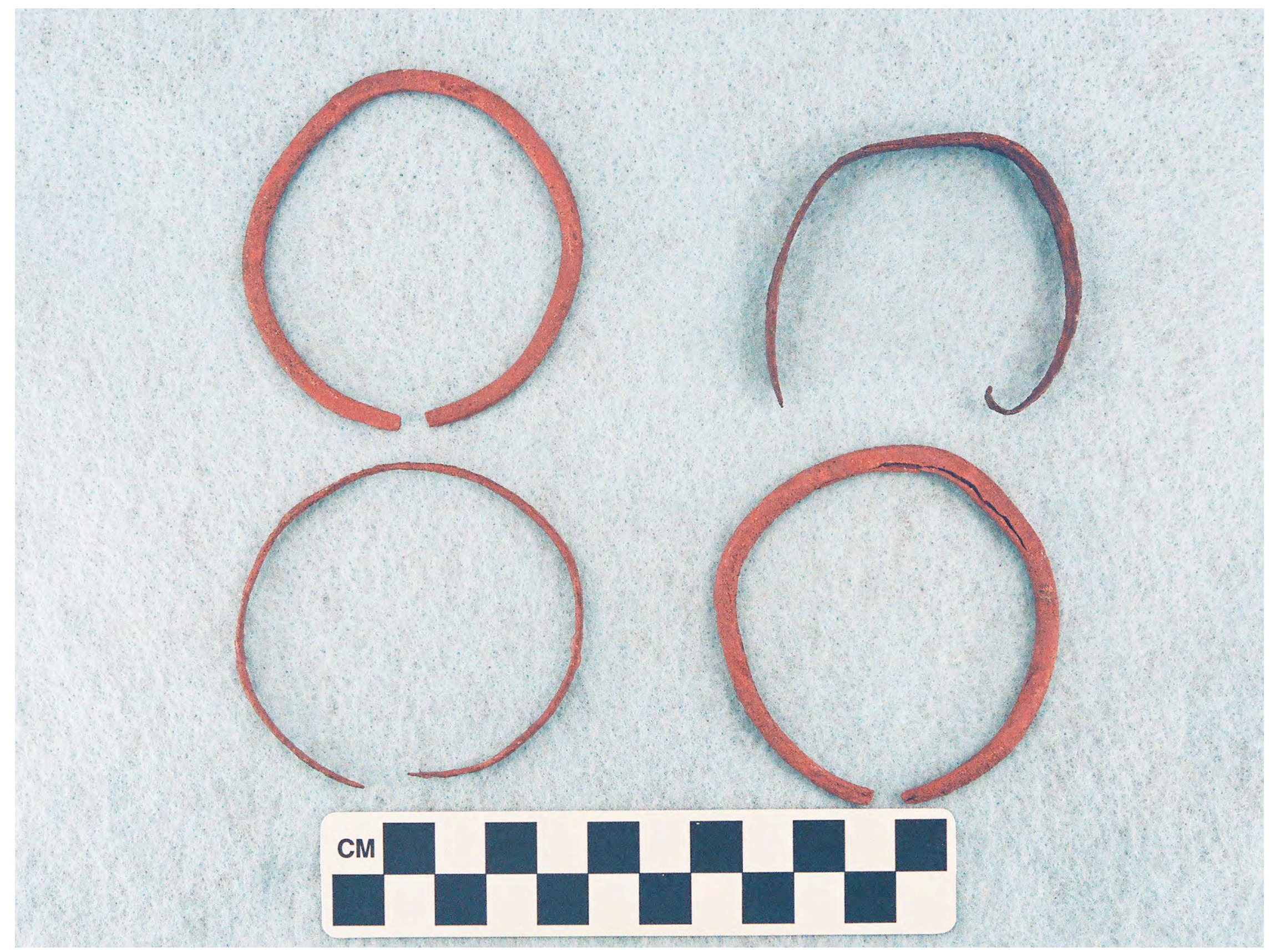

Figure 21 


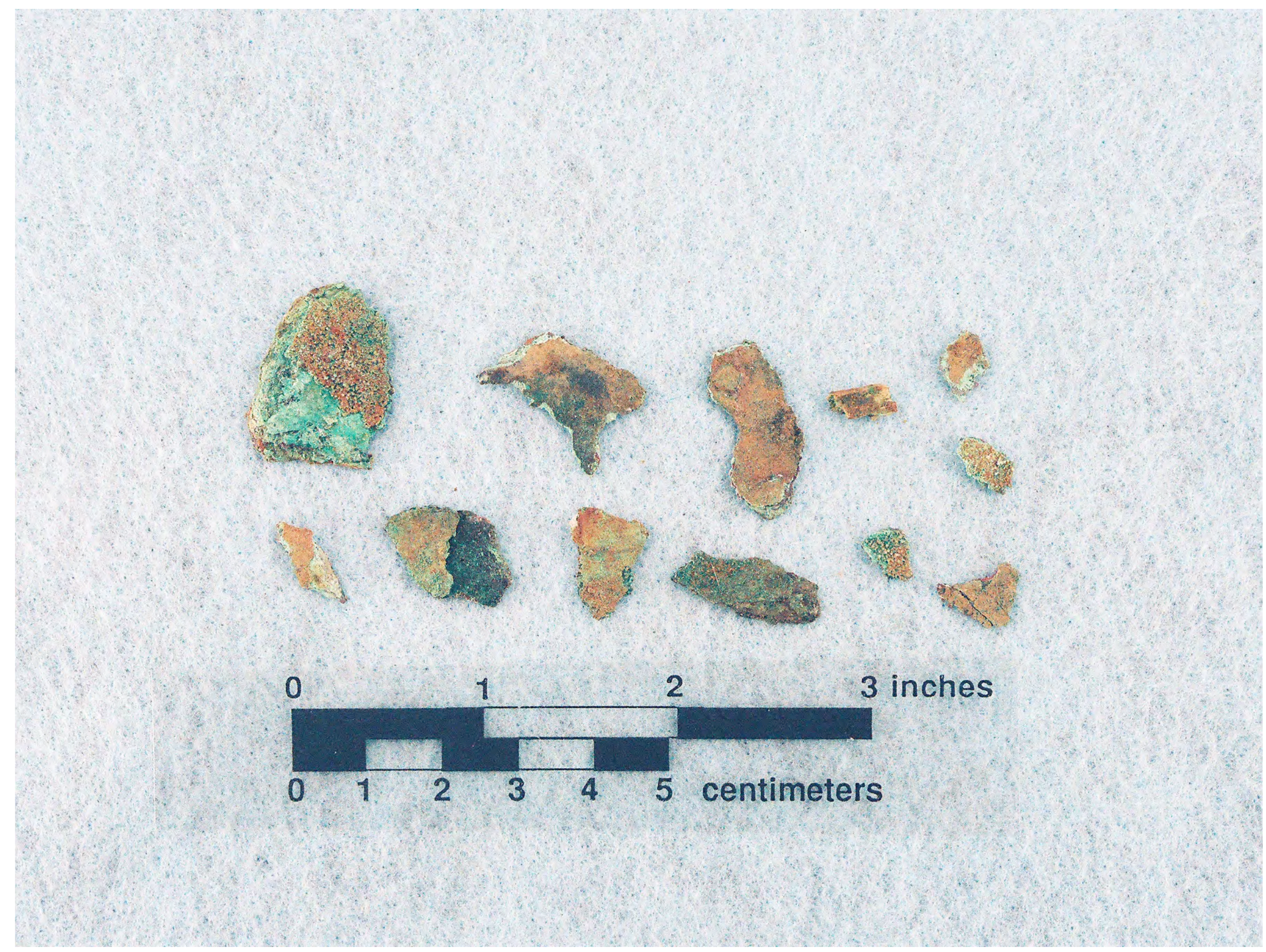

Figure 22 


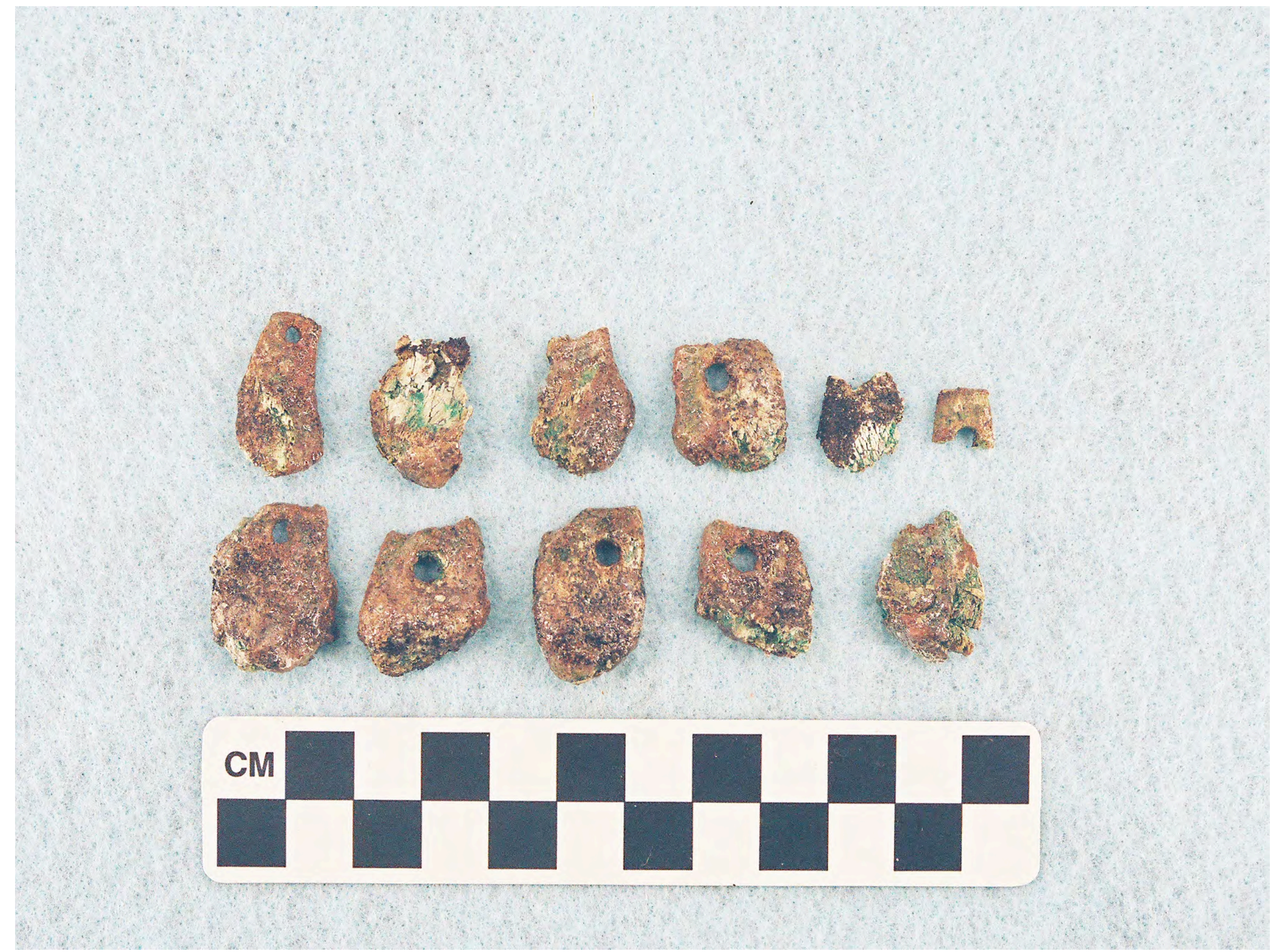

Figure 23 


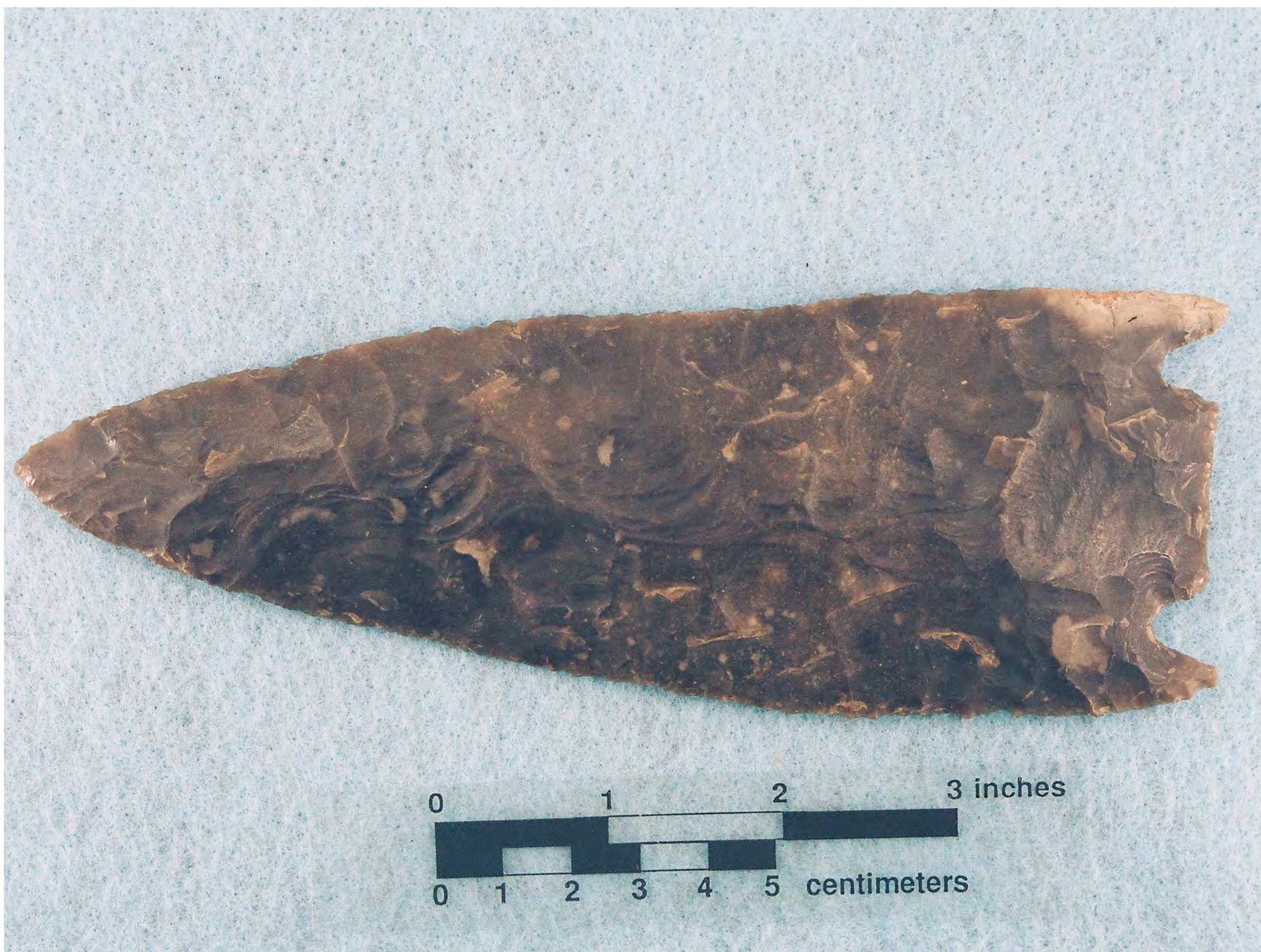

Figure 24 


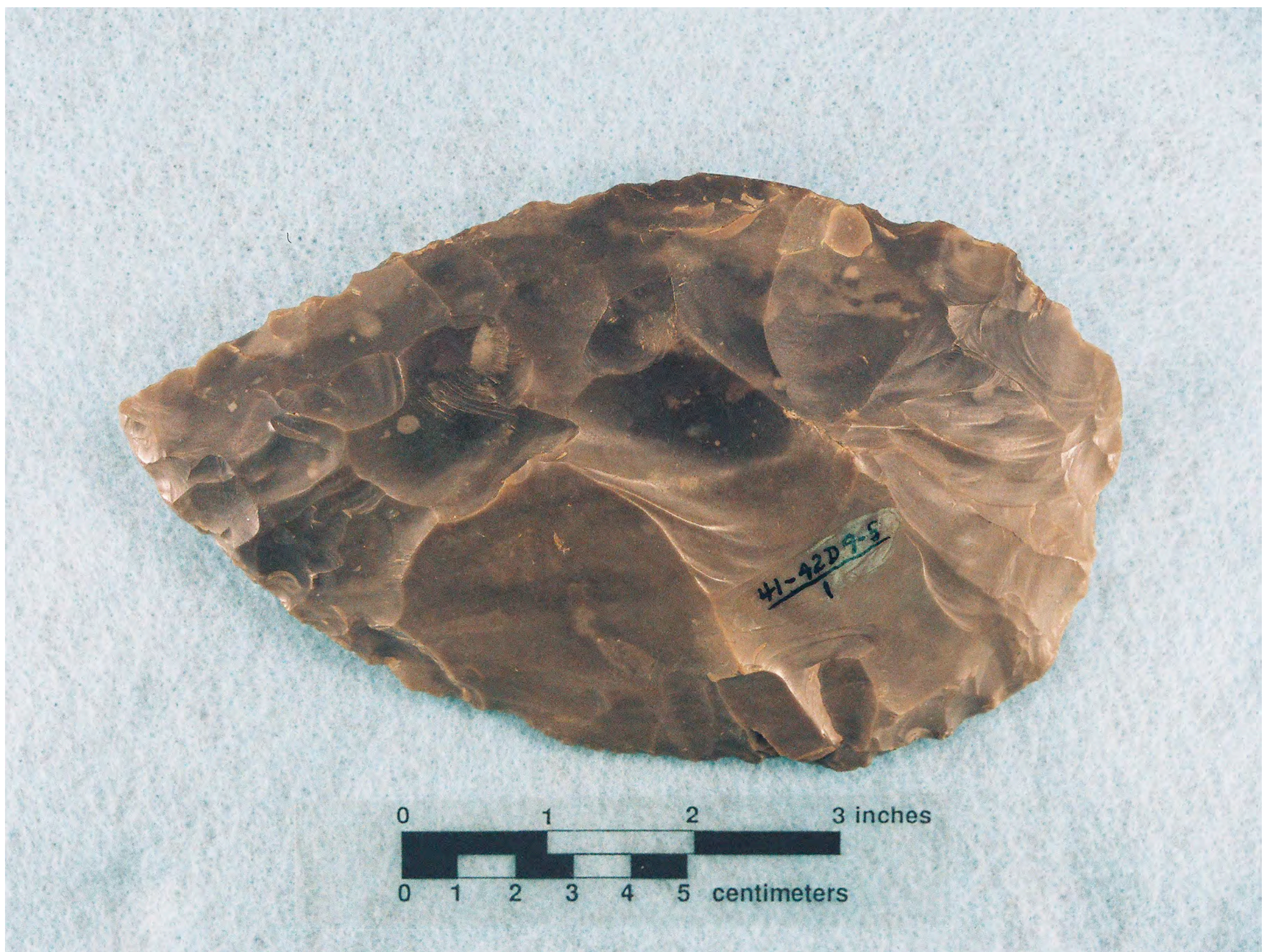

Figure 25 


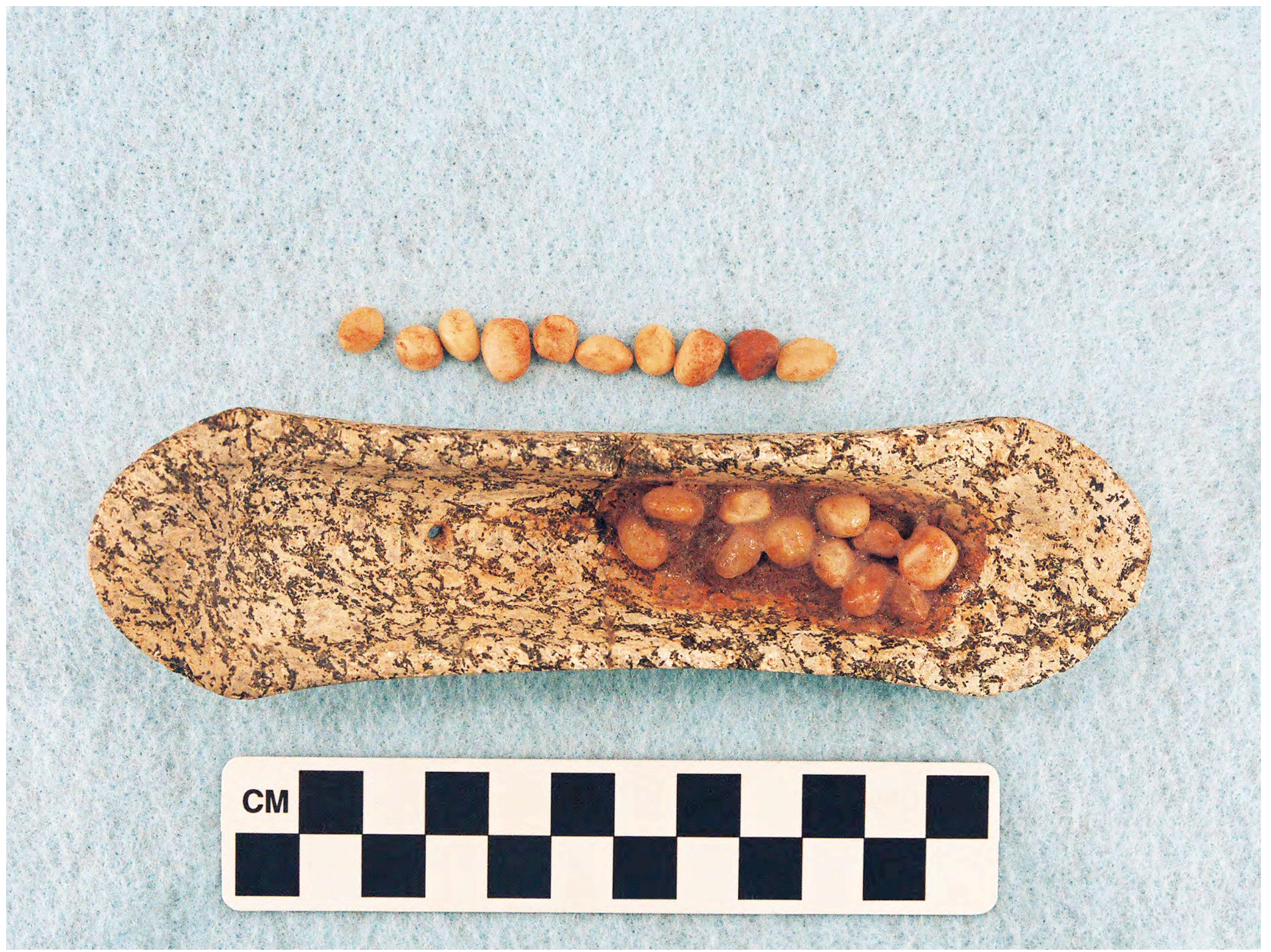

Figure 26a 


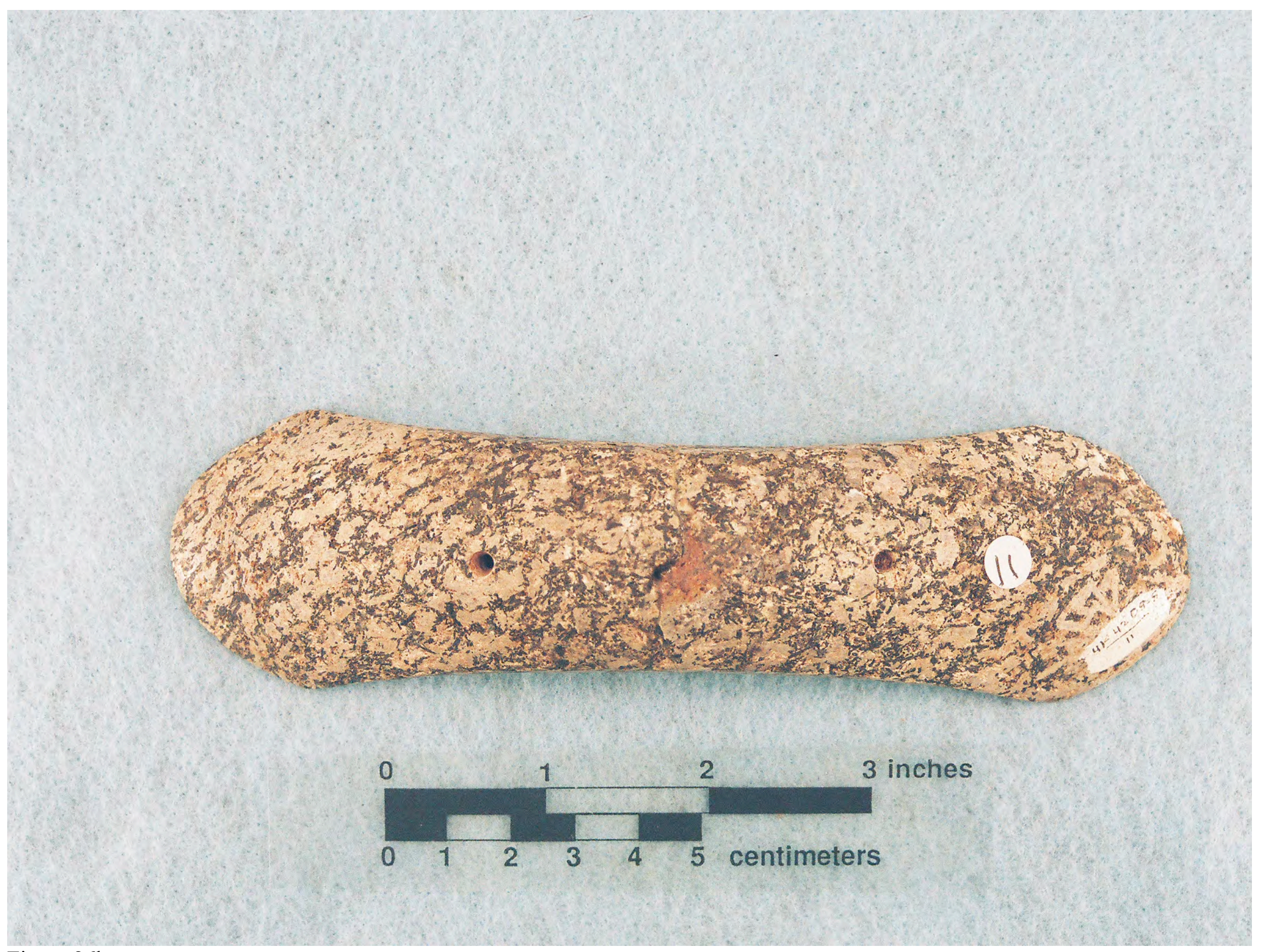

Figure 26b 


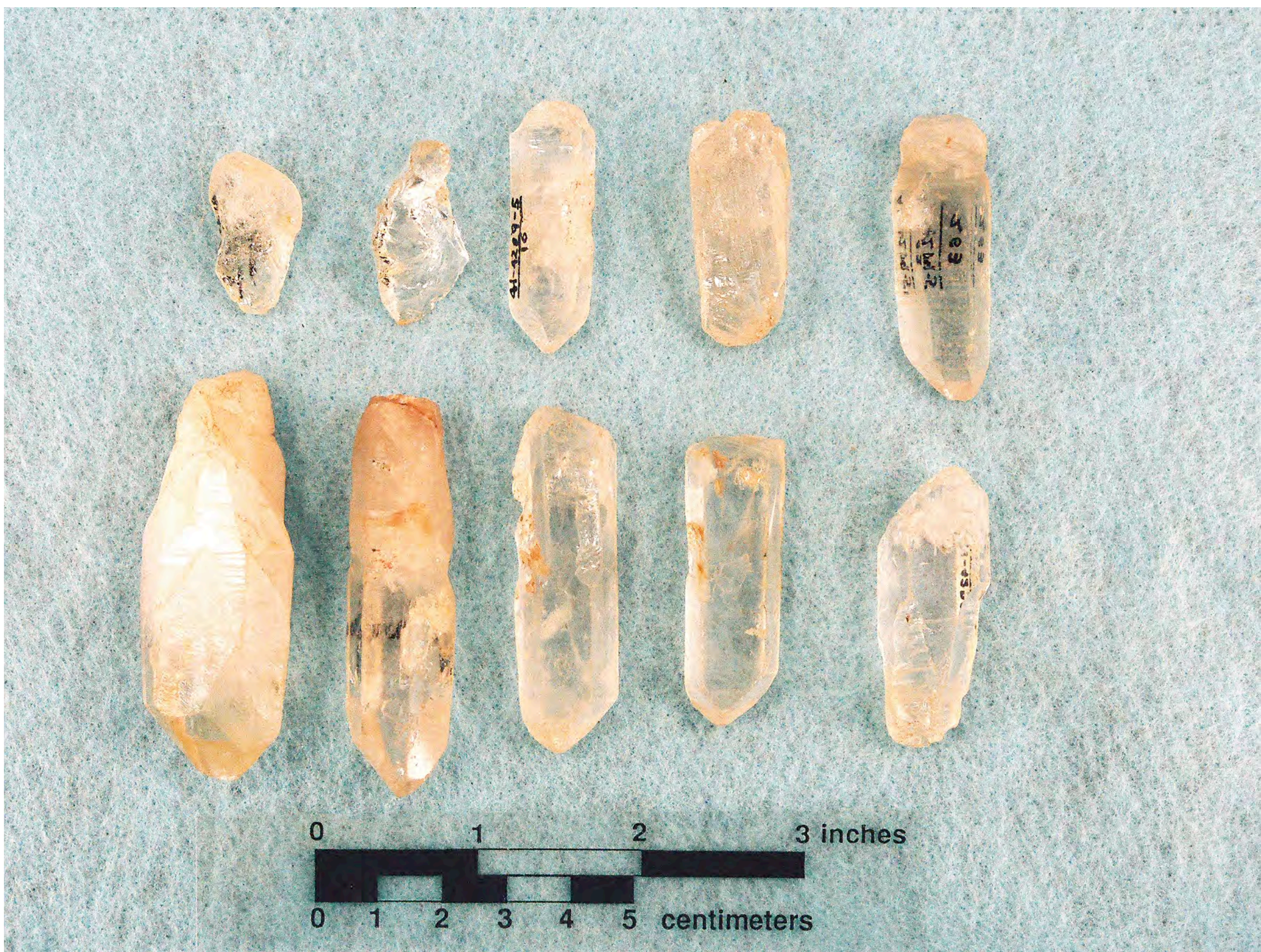

Figure 27 


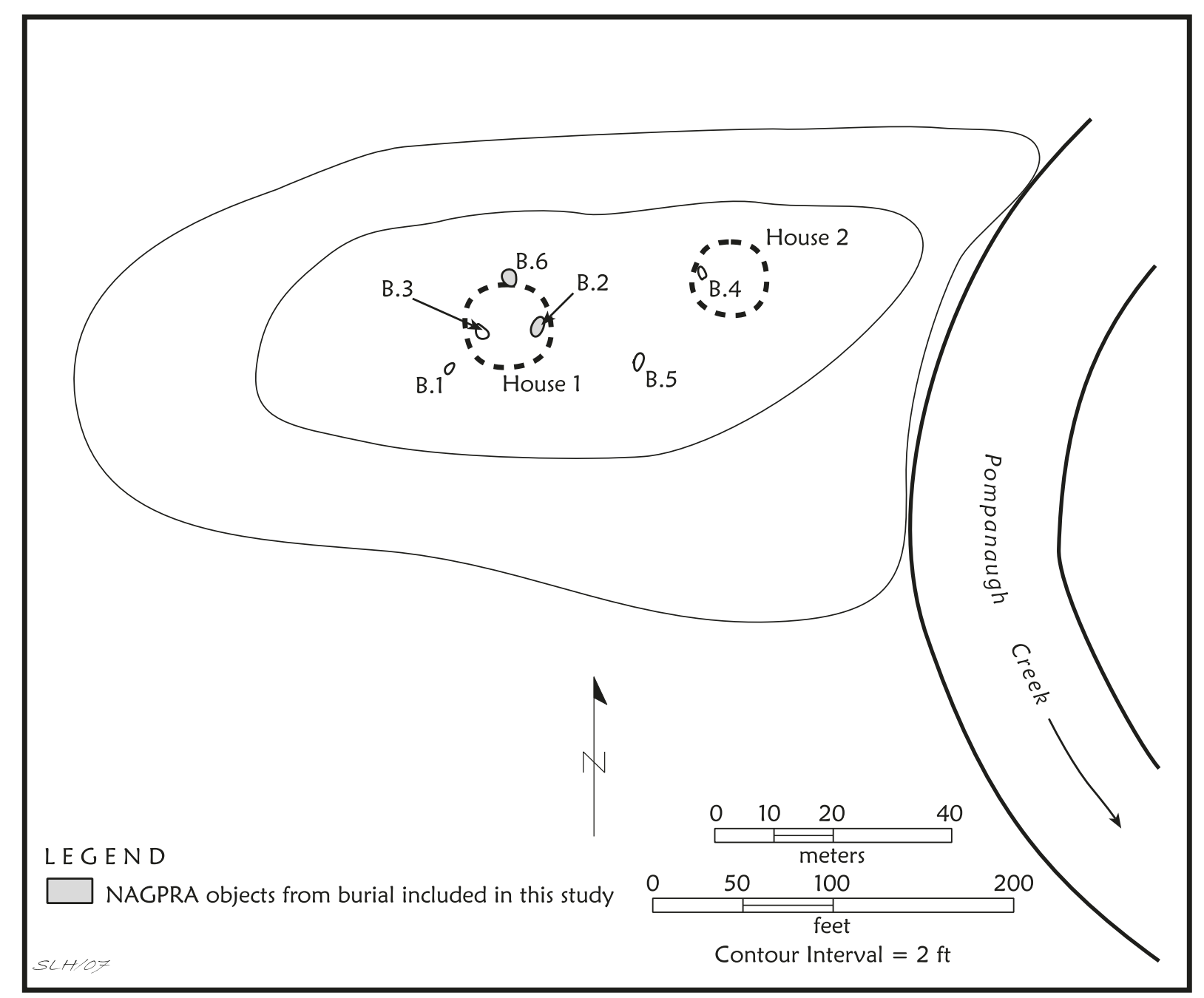

Figure 28 


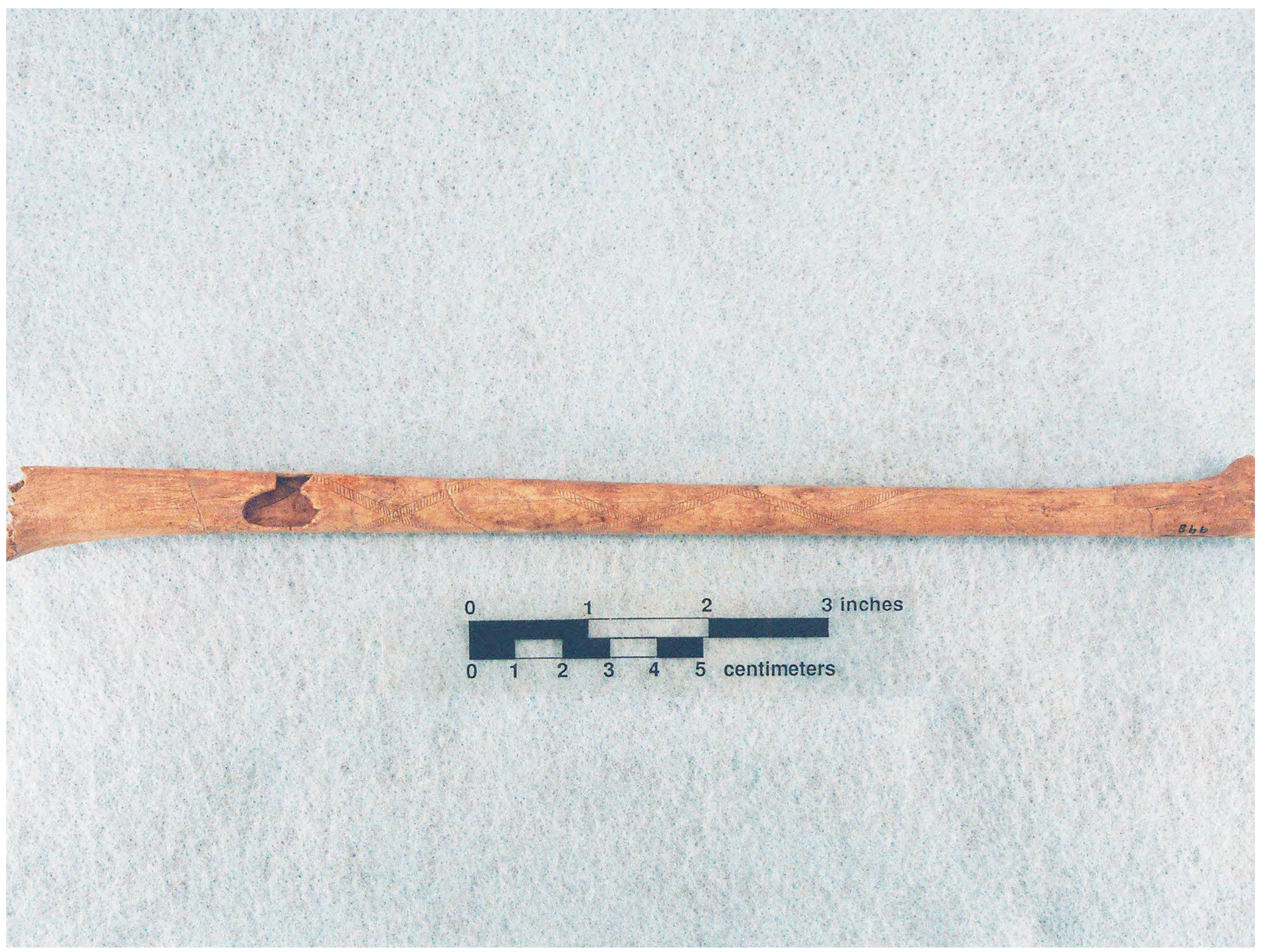

Figure 29 

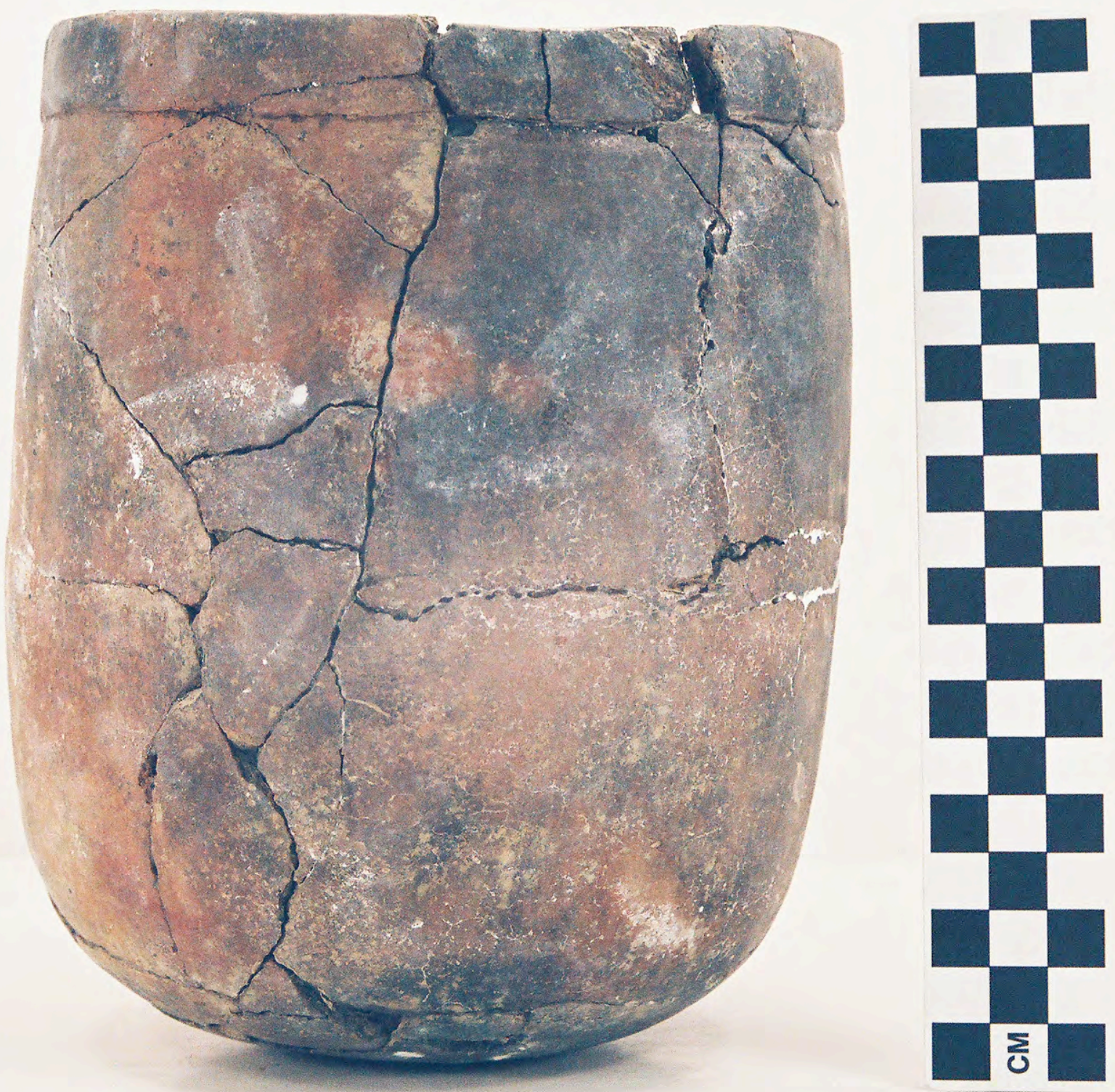

Figure $30 \mathrm{a}$ 


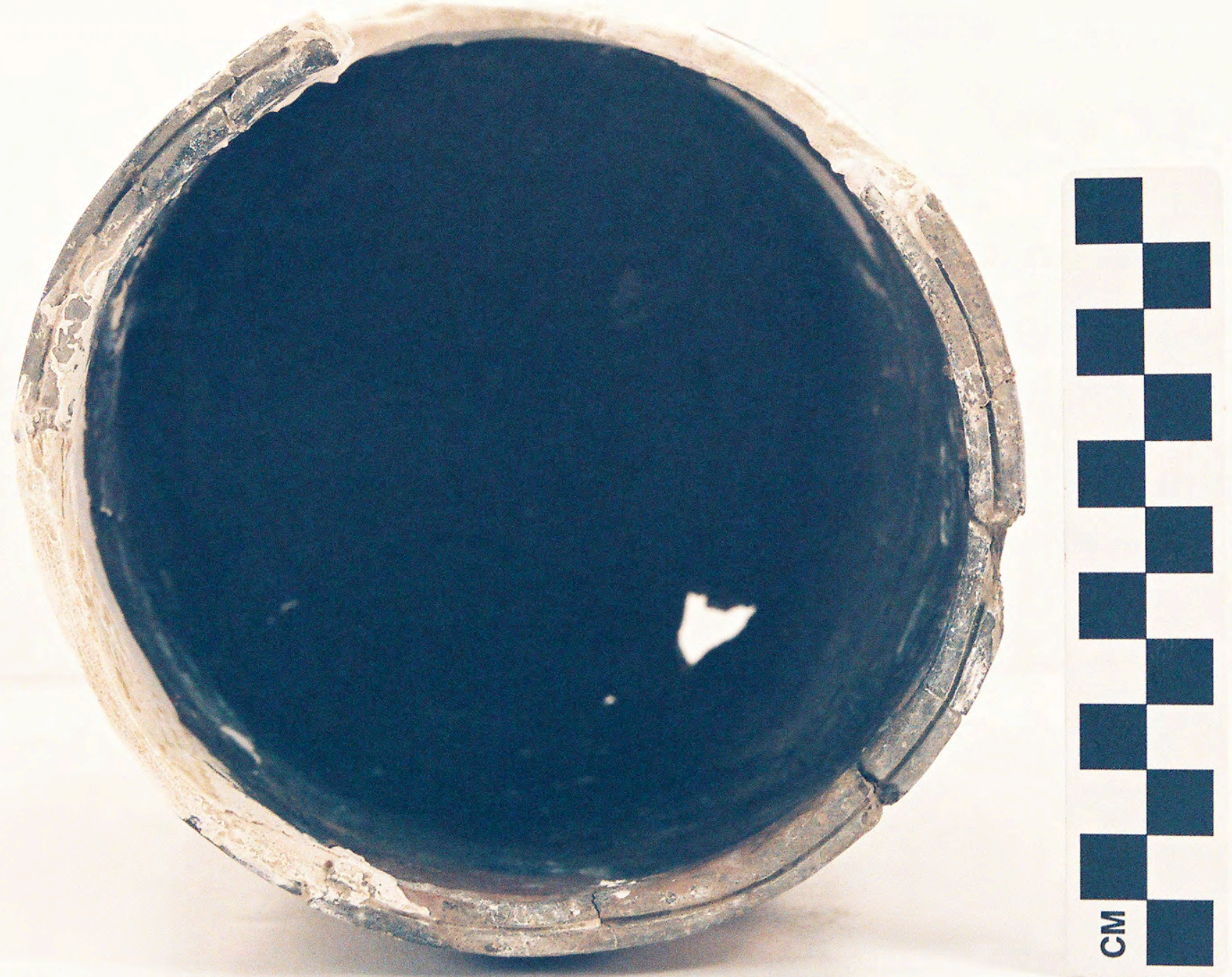

Figure $30 \mathrm{~b}$ 


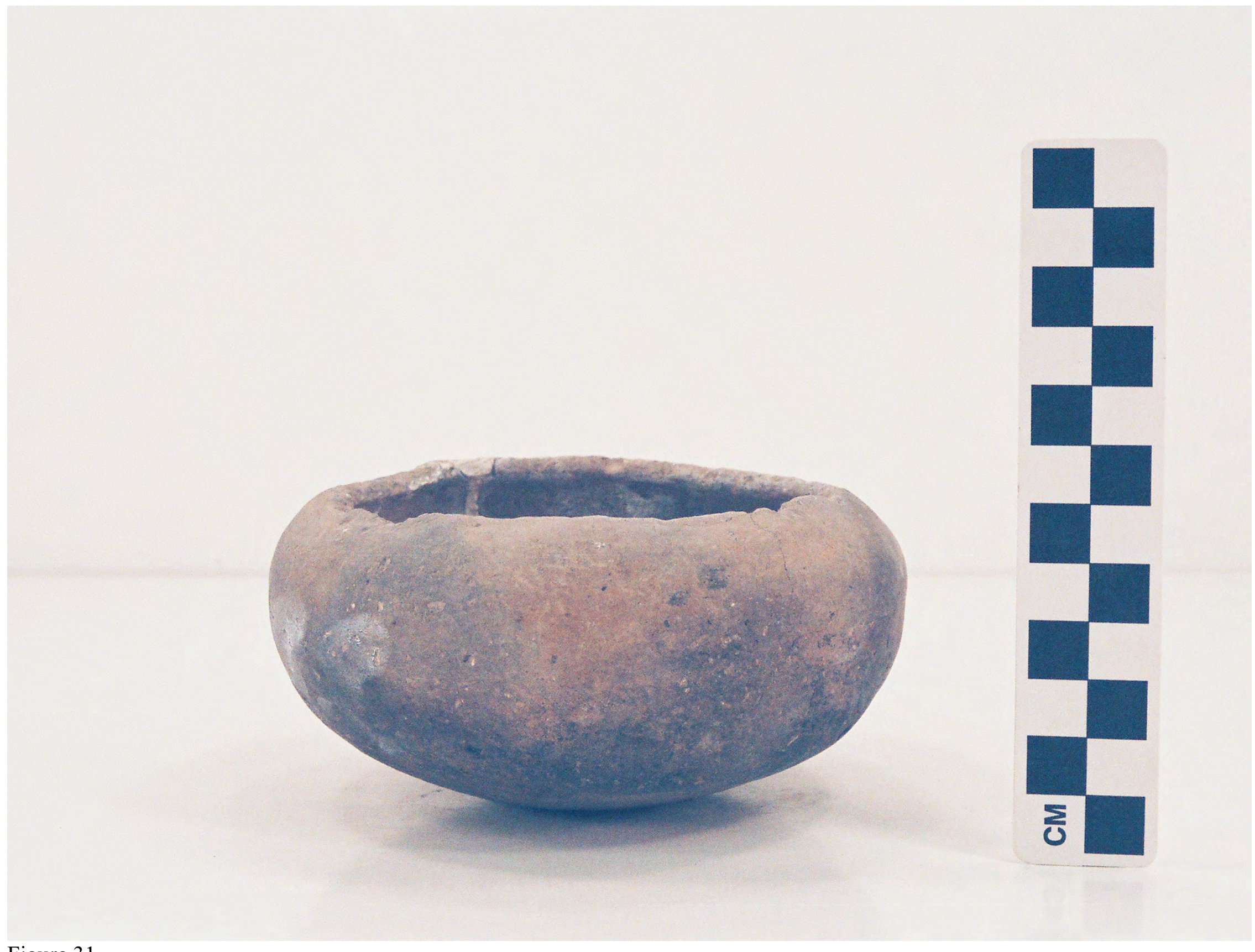

Figure 31 


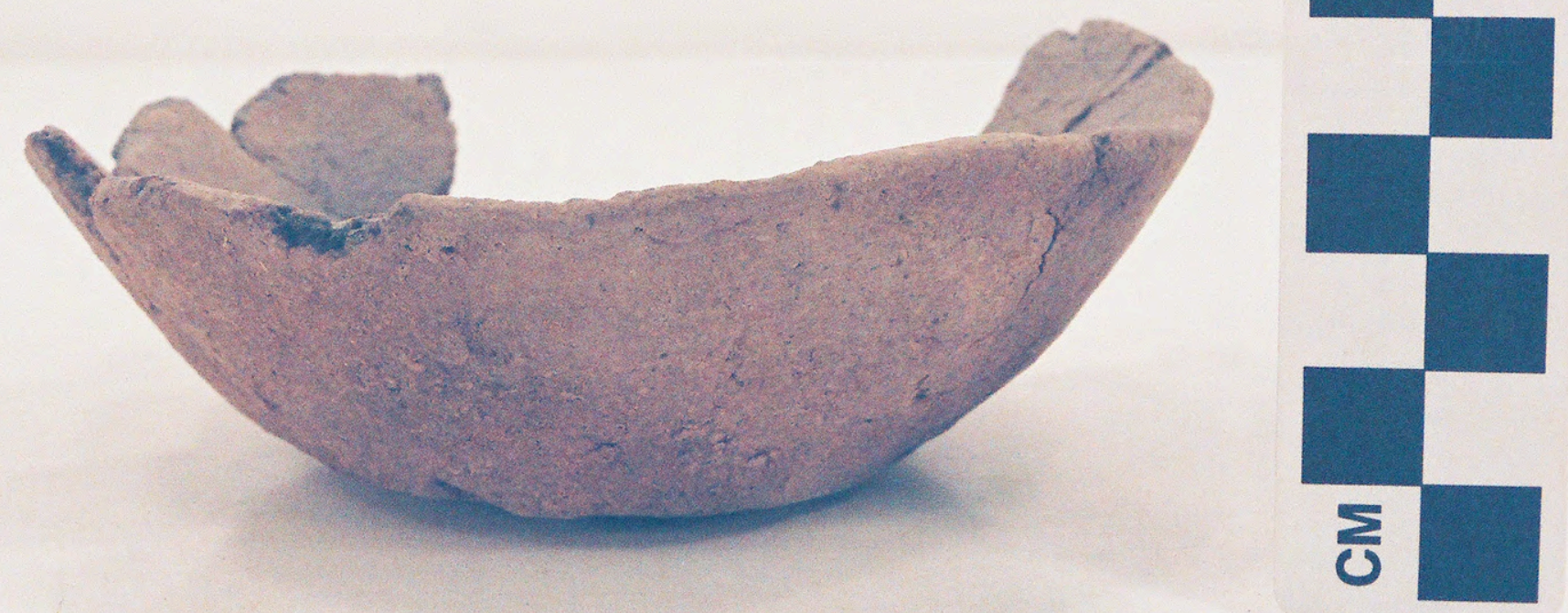

Figure 32 


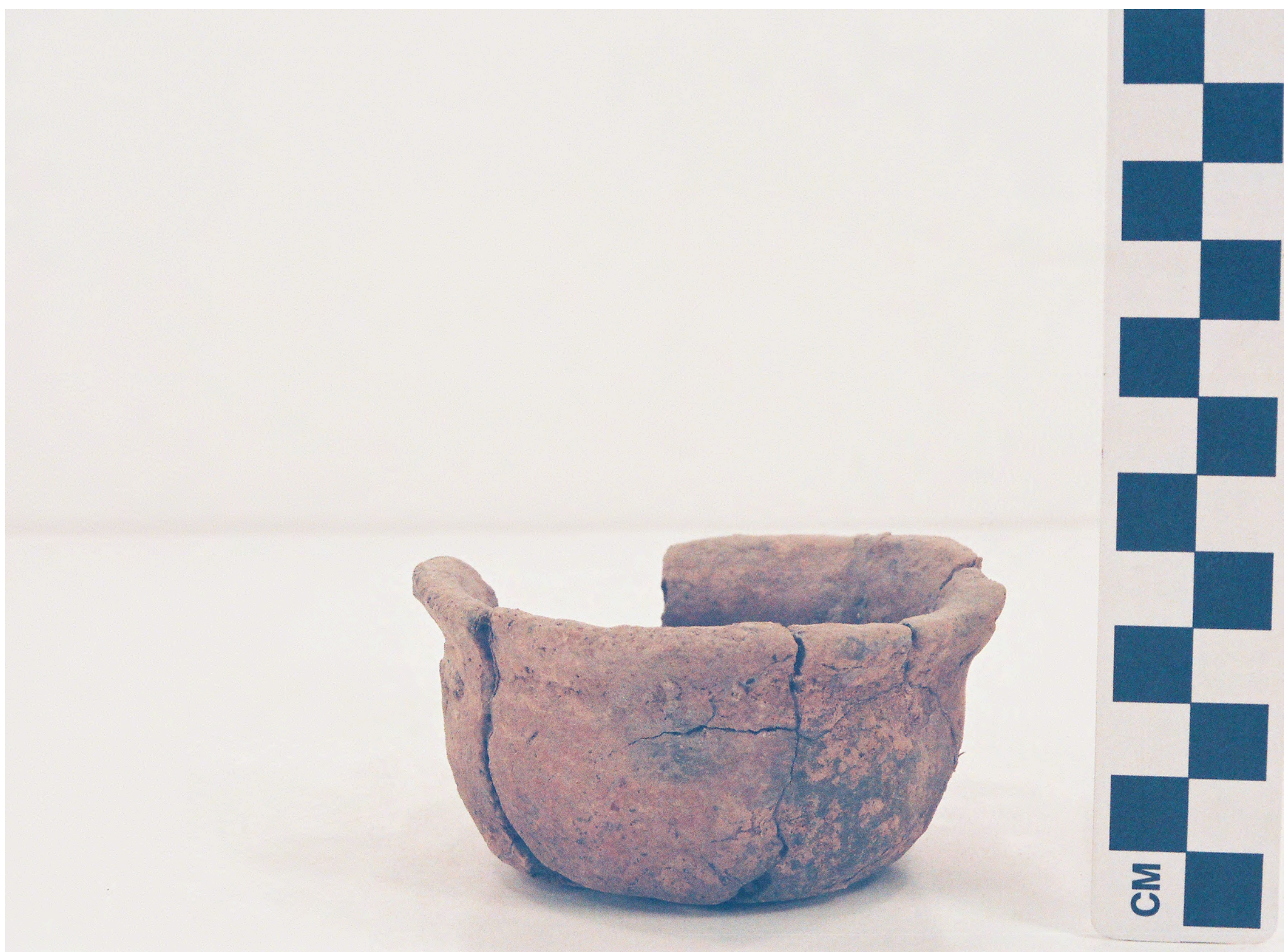

Figure 33 


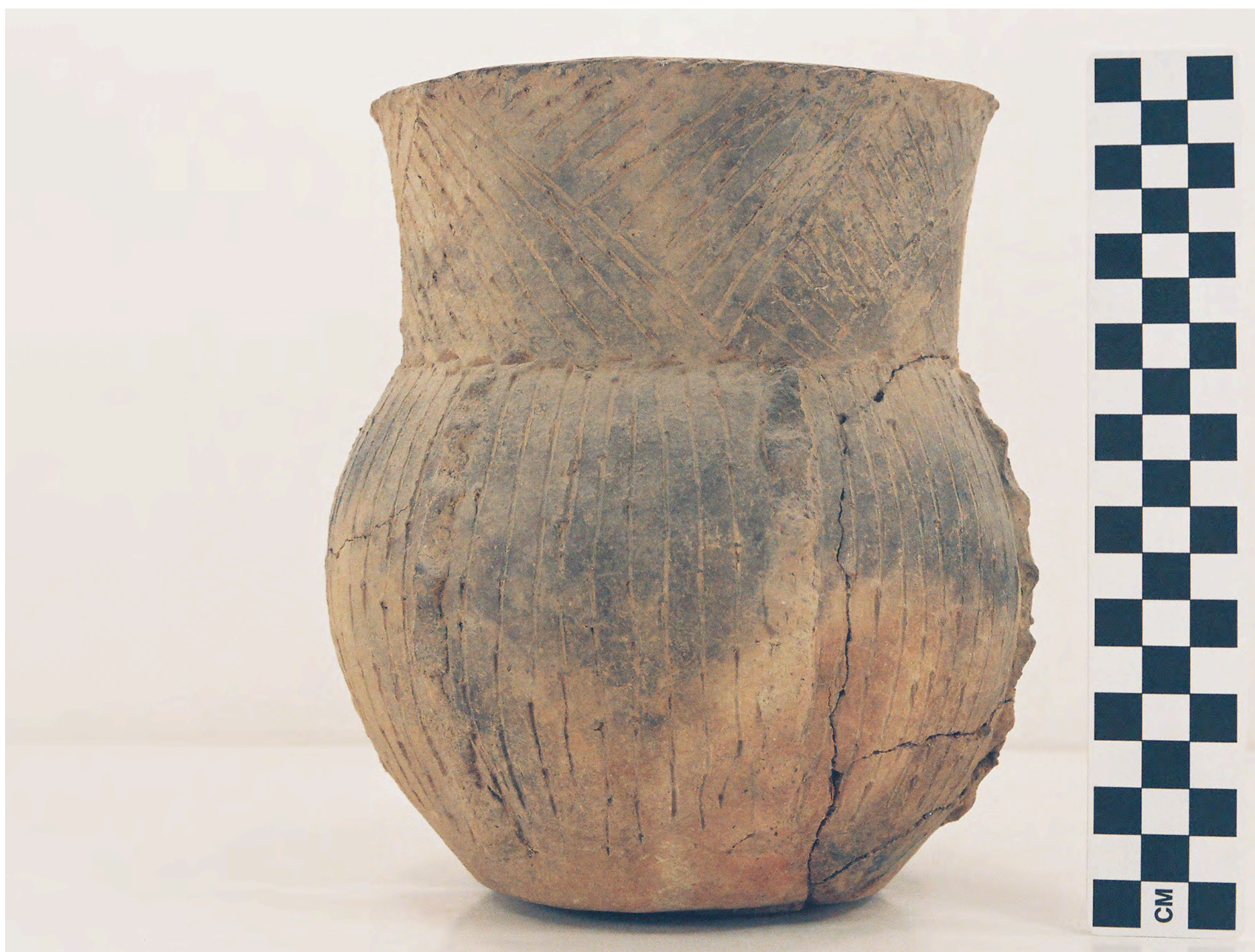

Figure $34 a$ 


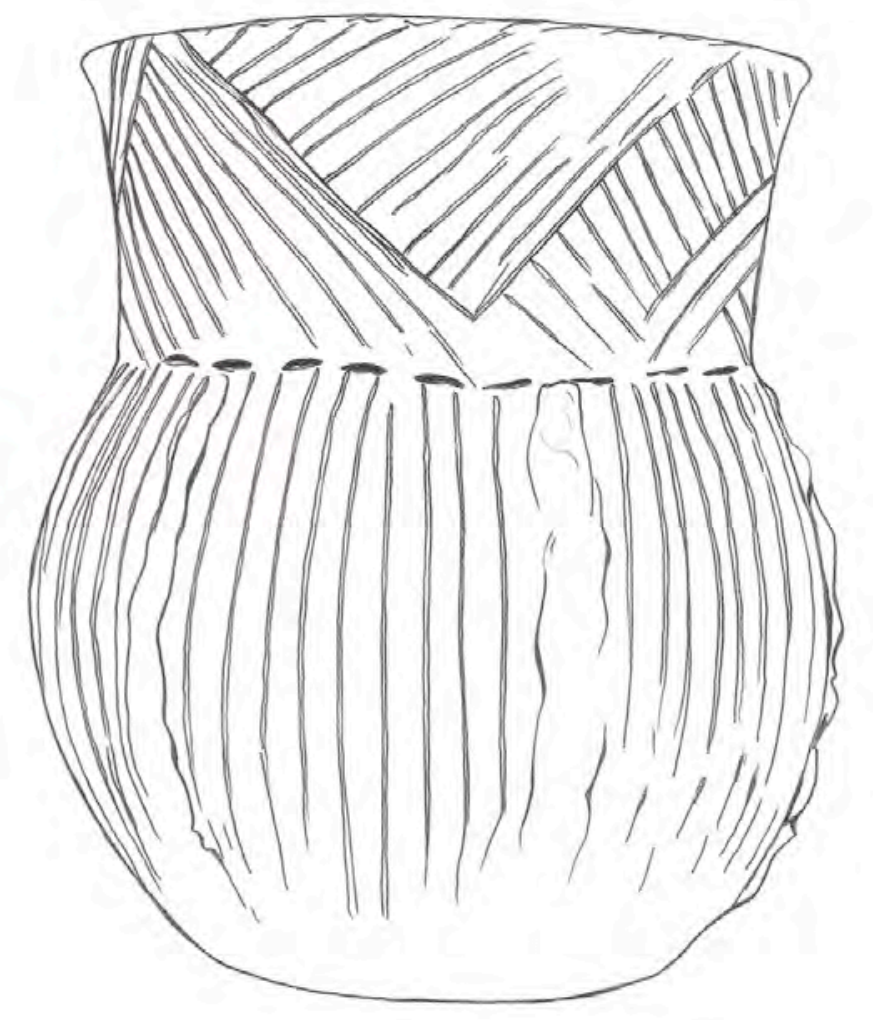

Figure 34. Pease Brushed-Incised vessel from Burial 4 at the Knight's Bluff site: $b$ drawing by Bobby Gonzalez

Figure $34 b$ 

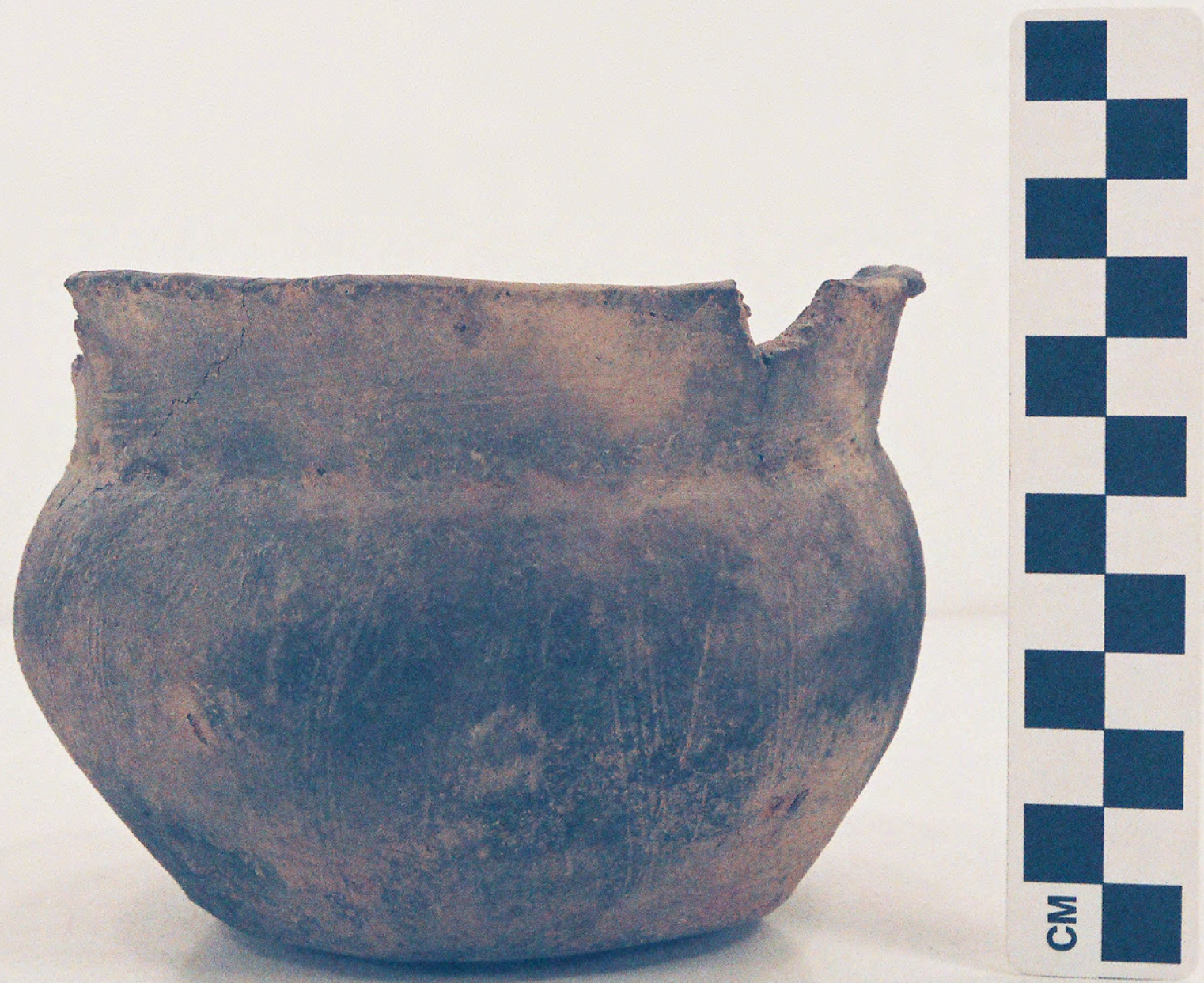

Figure 35 


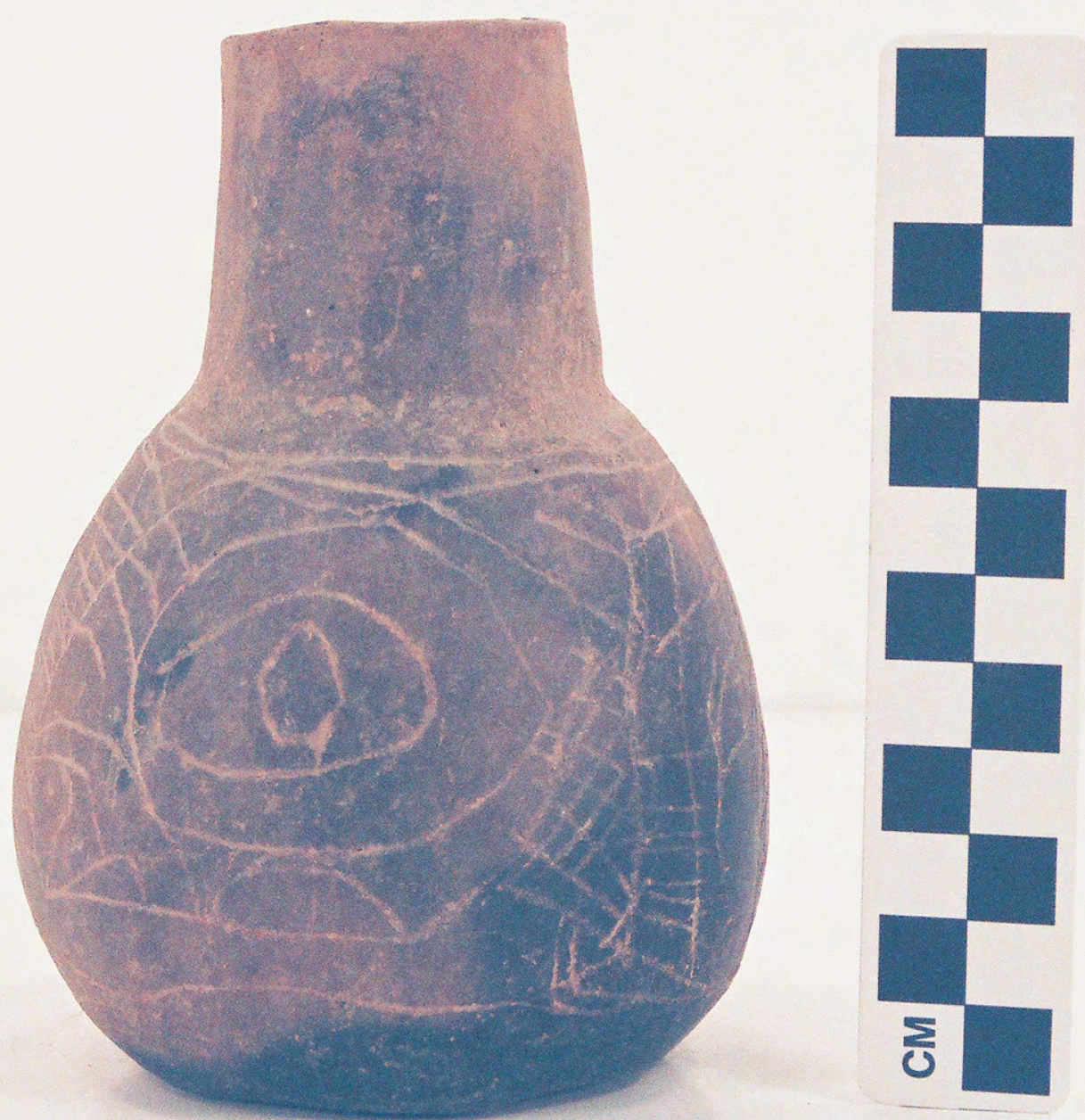

Figure 36 

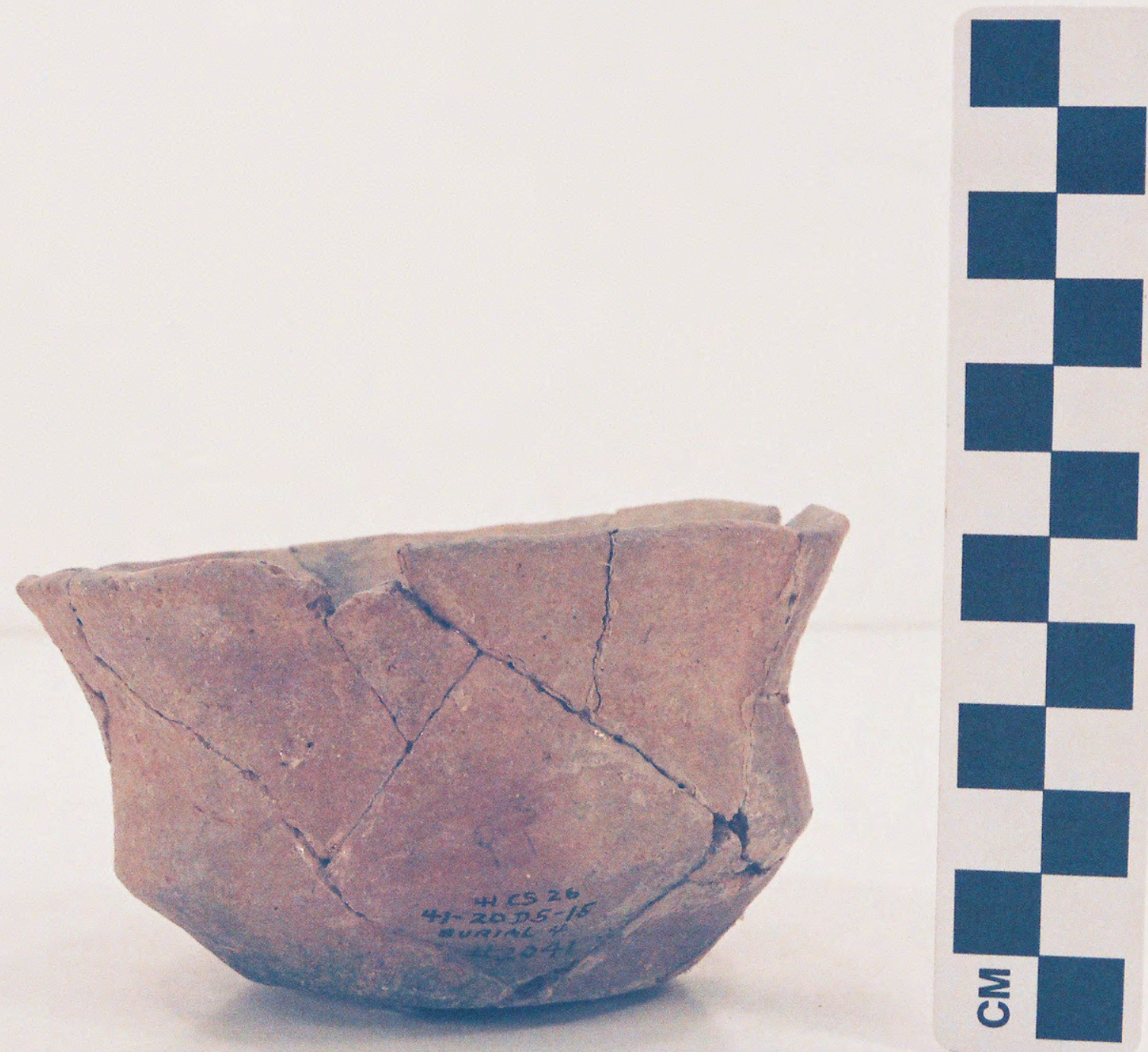

Figure 37 

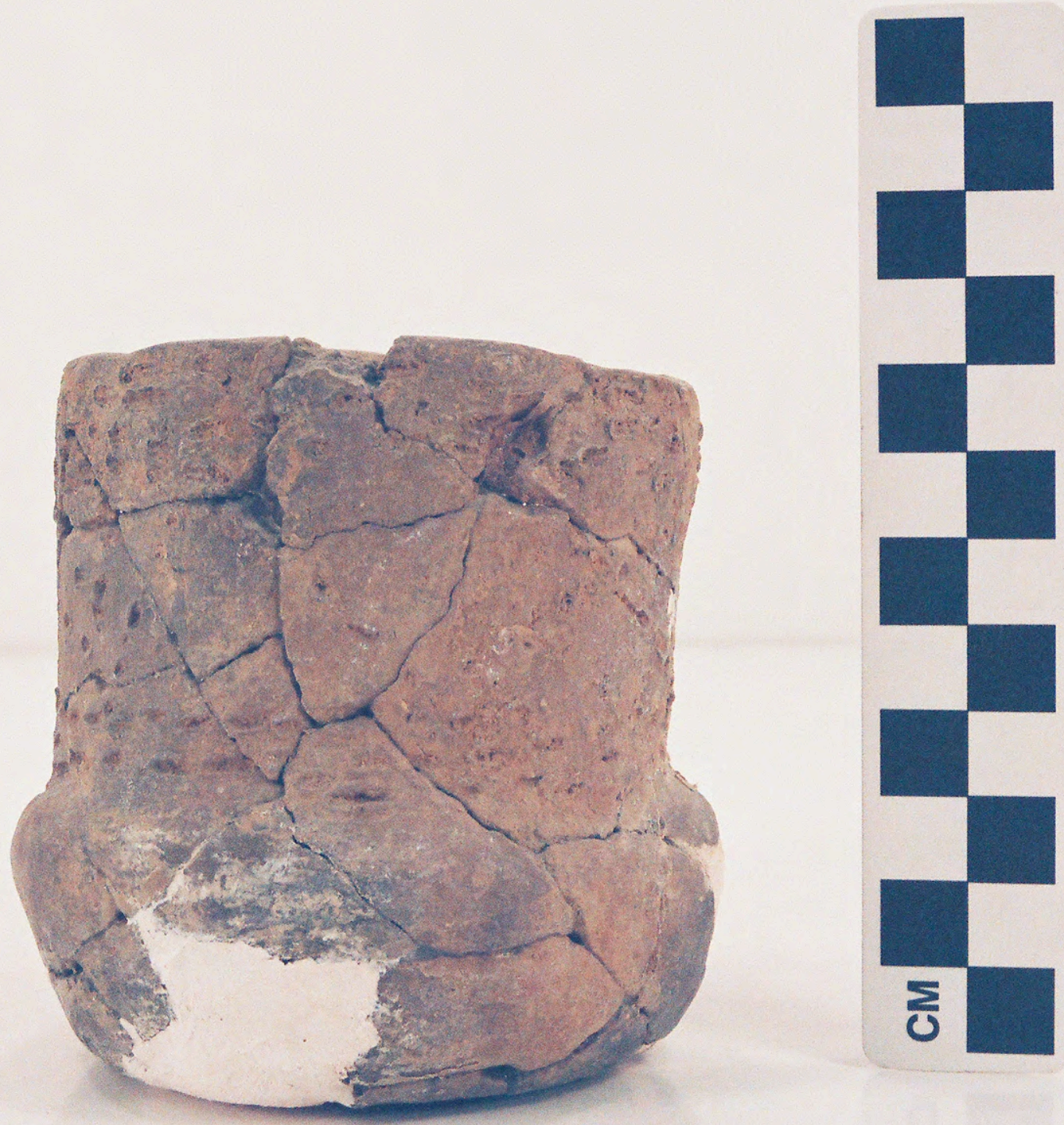

Figure 38 


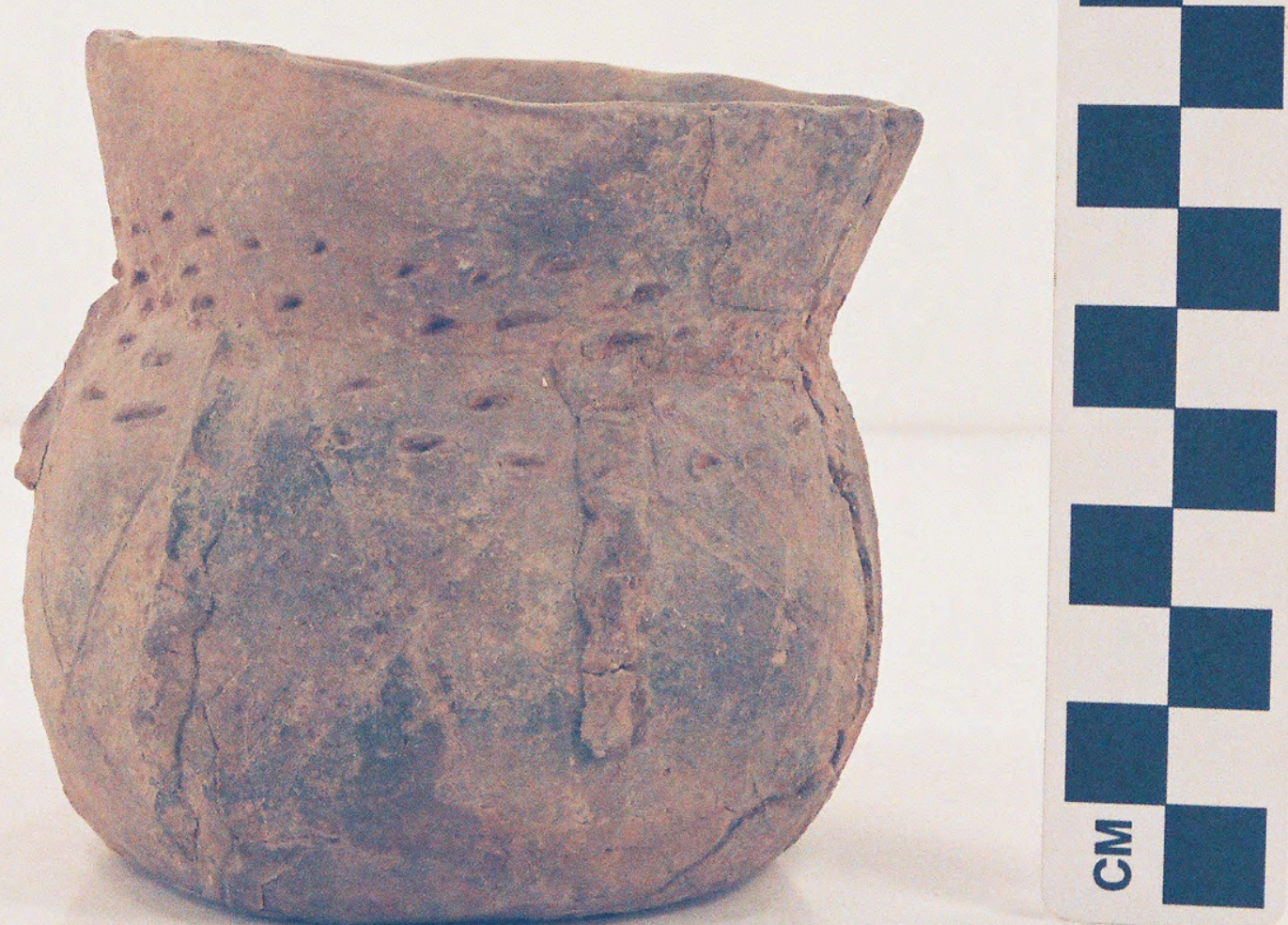

Figure 39 


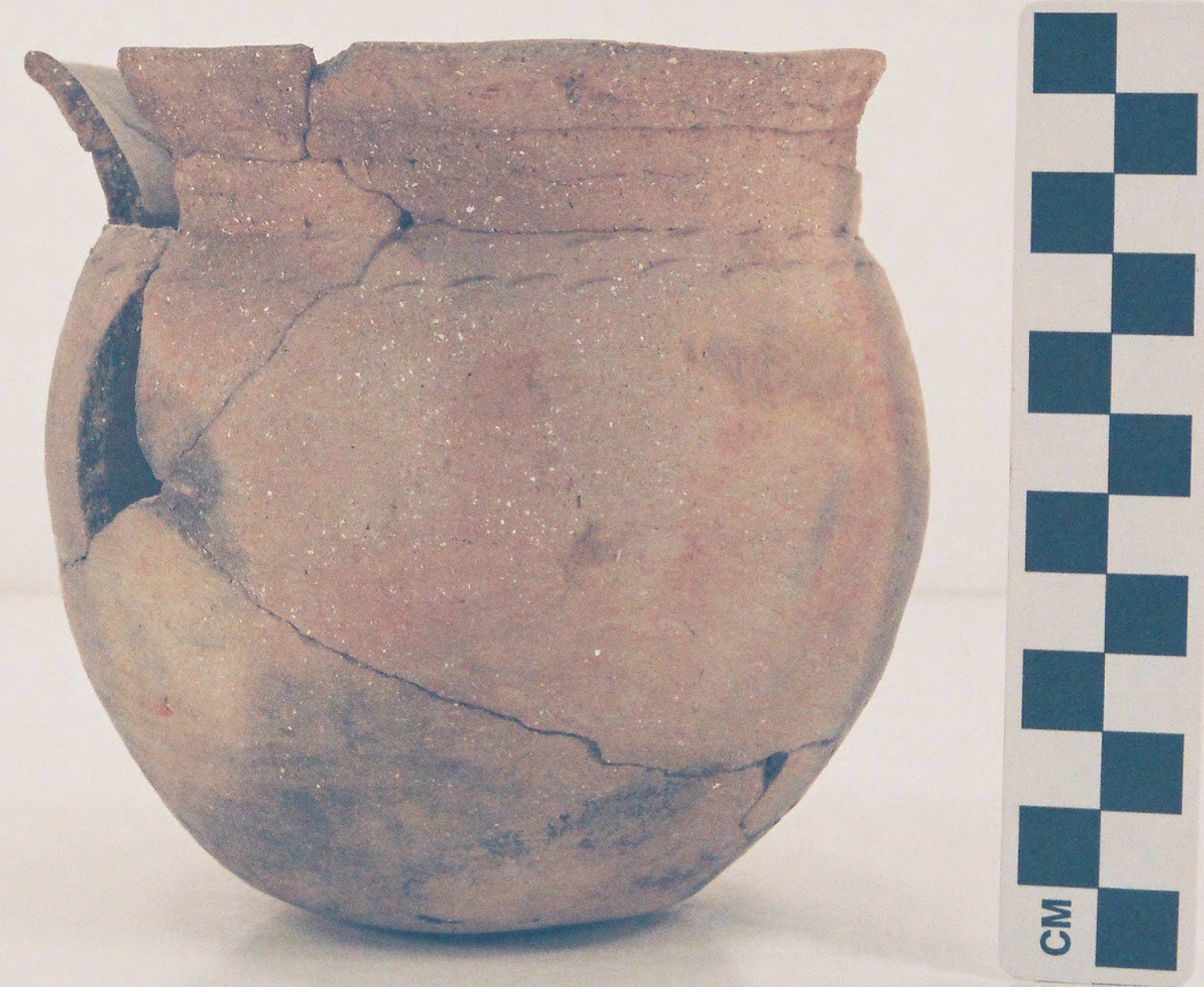

Figure 40 

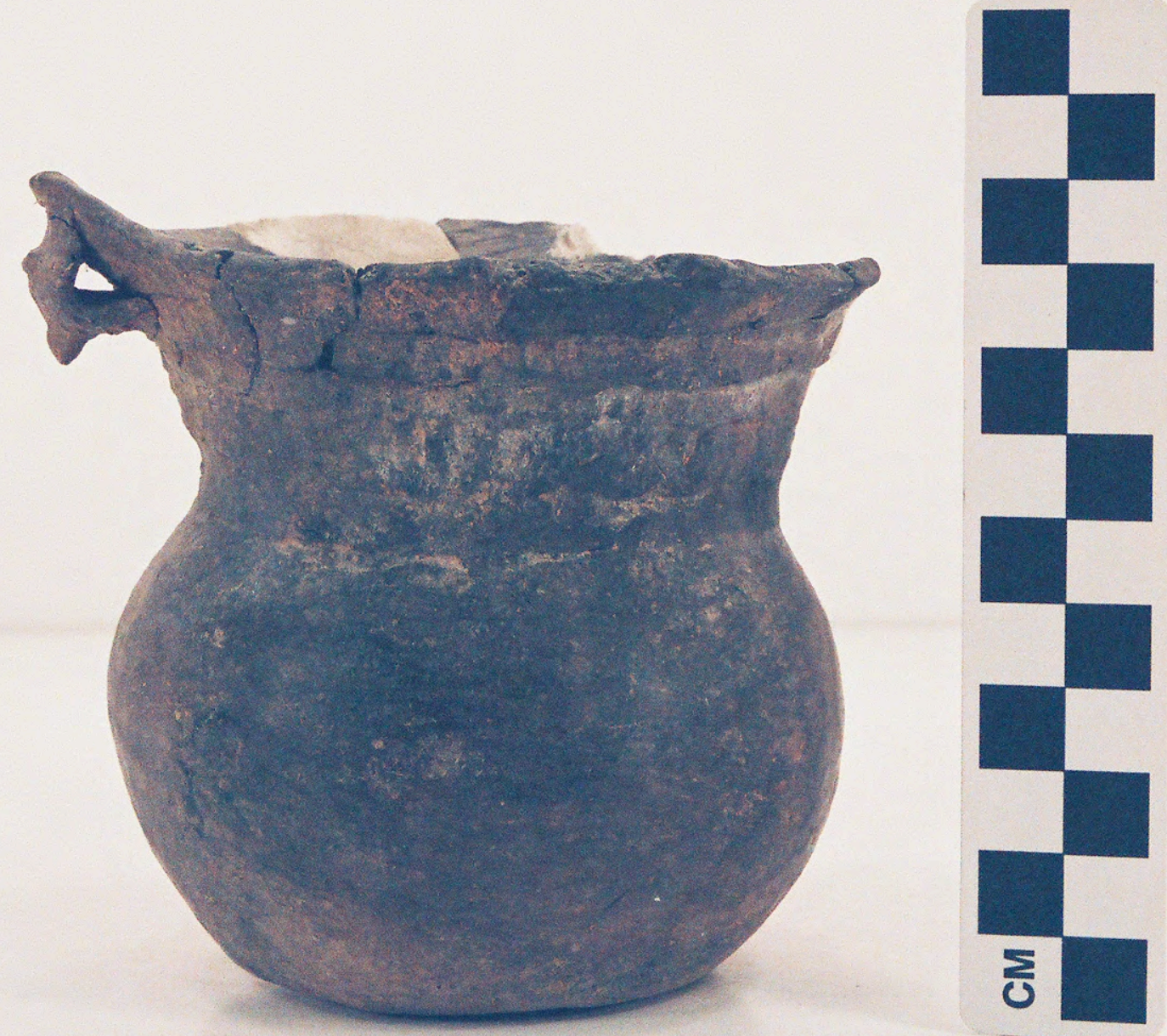

Figure 41 


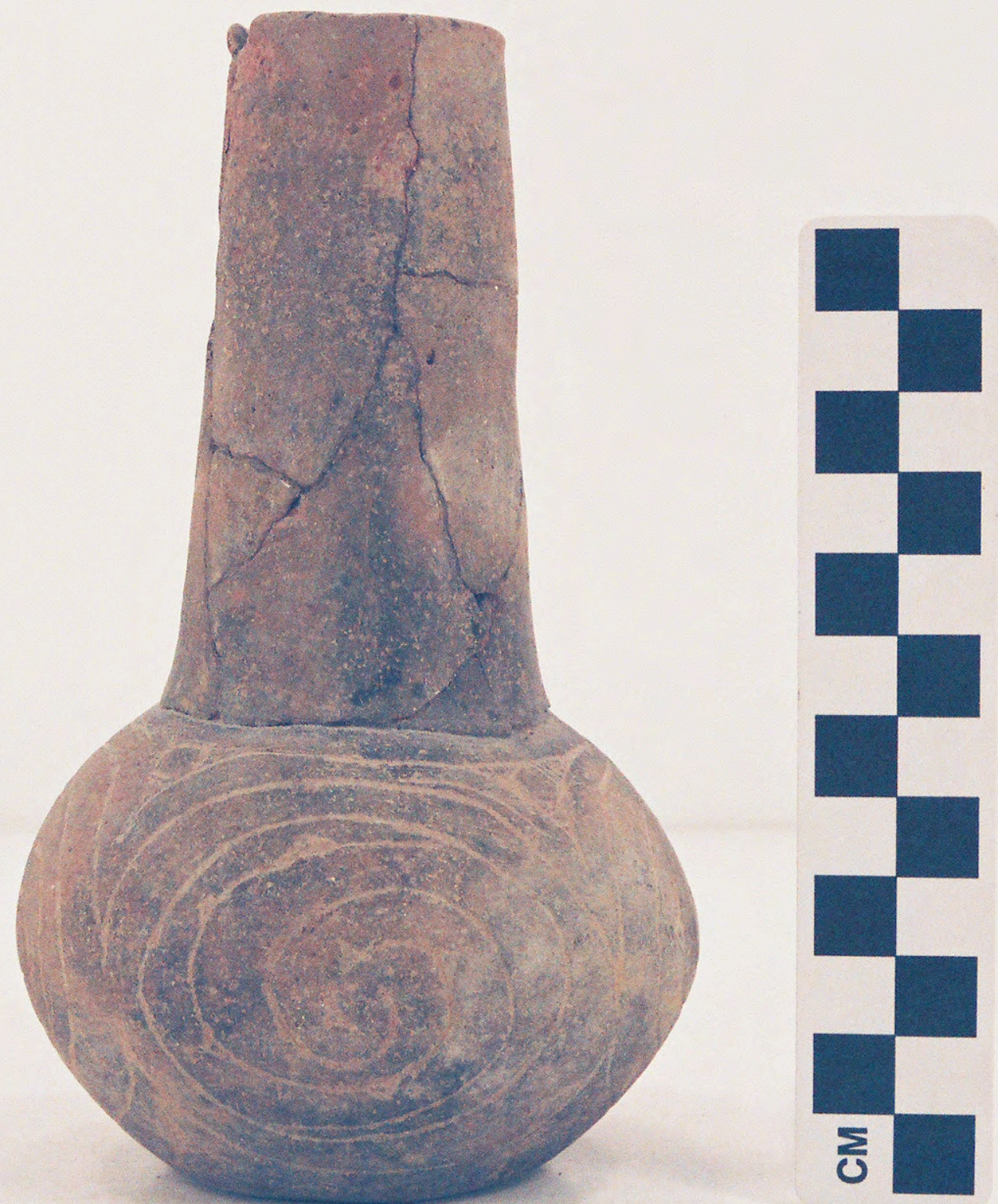

Figure 42 


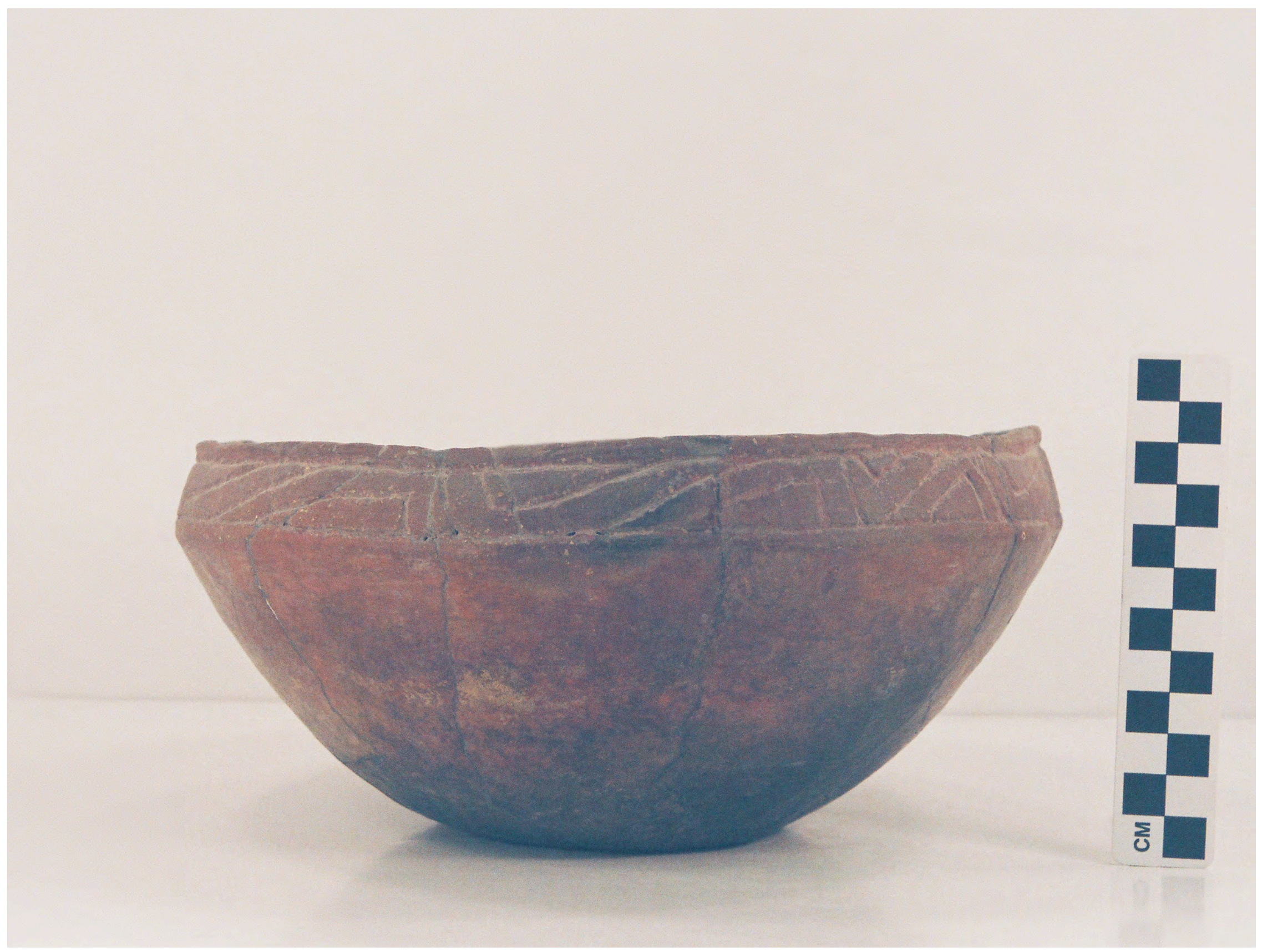

Figure 43 

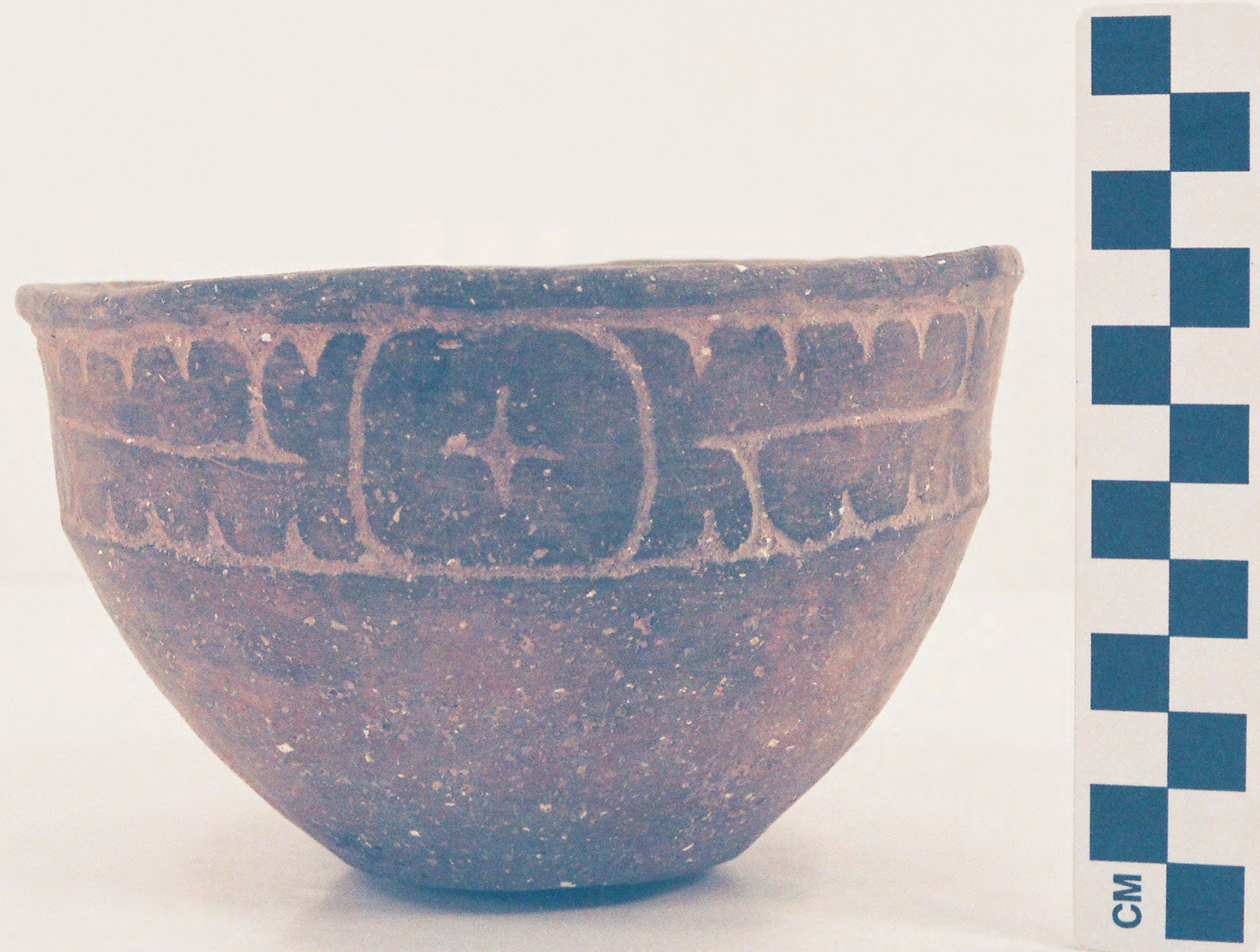

Figure 44a 


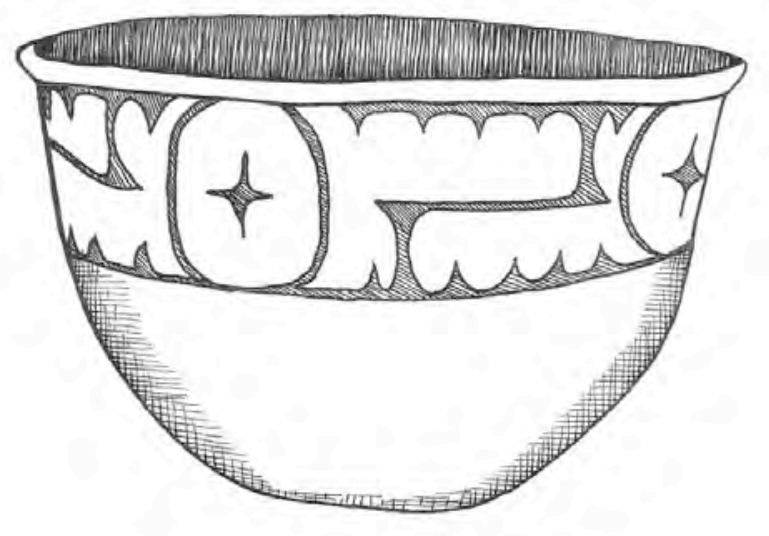

Figure 44. Ripley Engraved vessel MR 12-36: b, drawing by Bobby Gonzaiez

Figure $44 b$ 

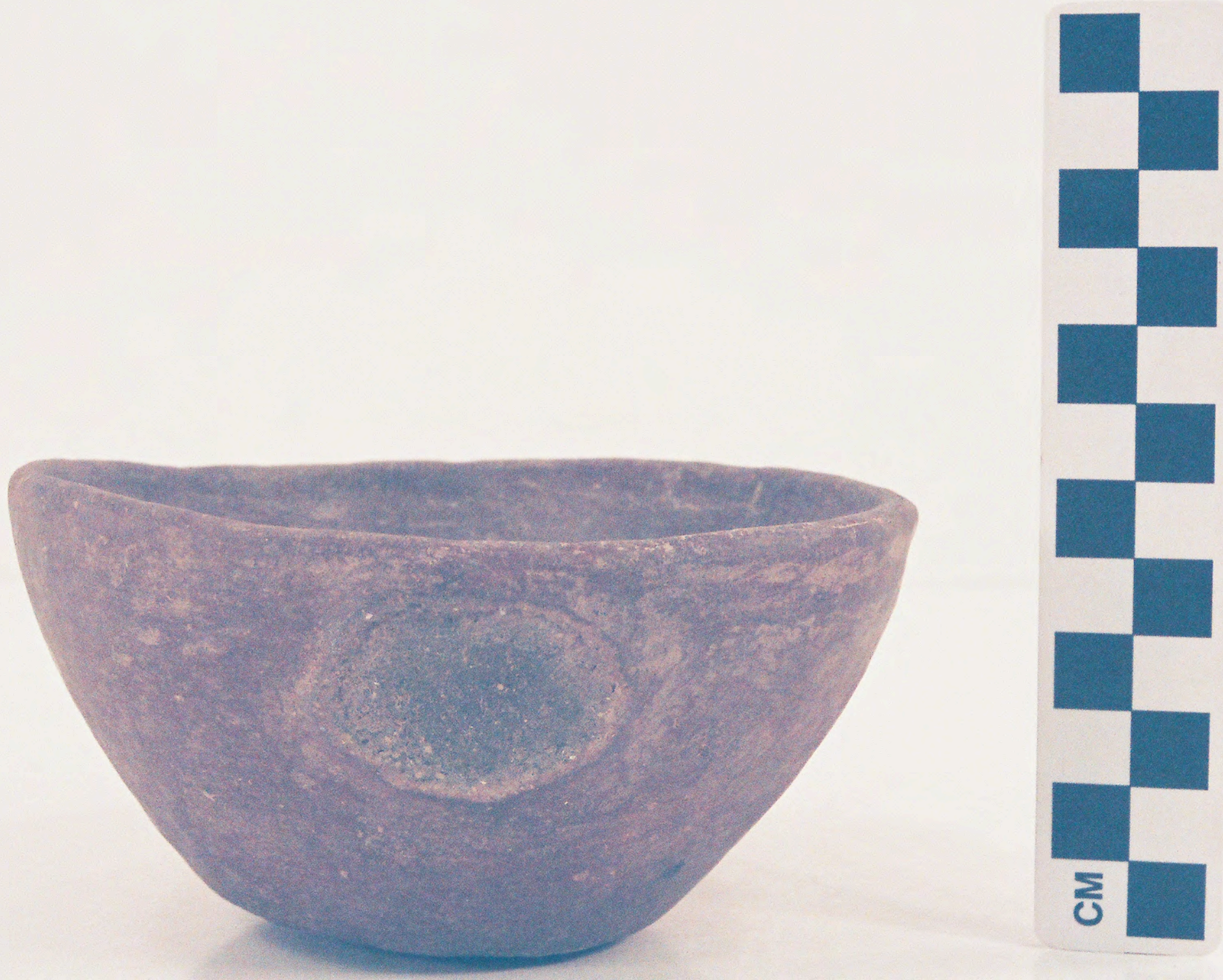

Figure 45 


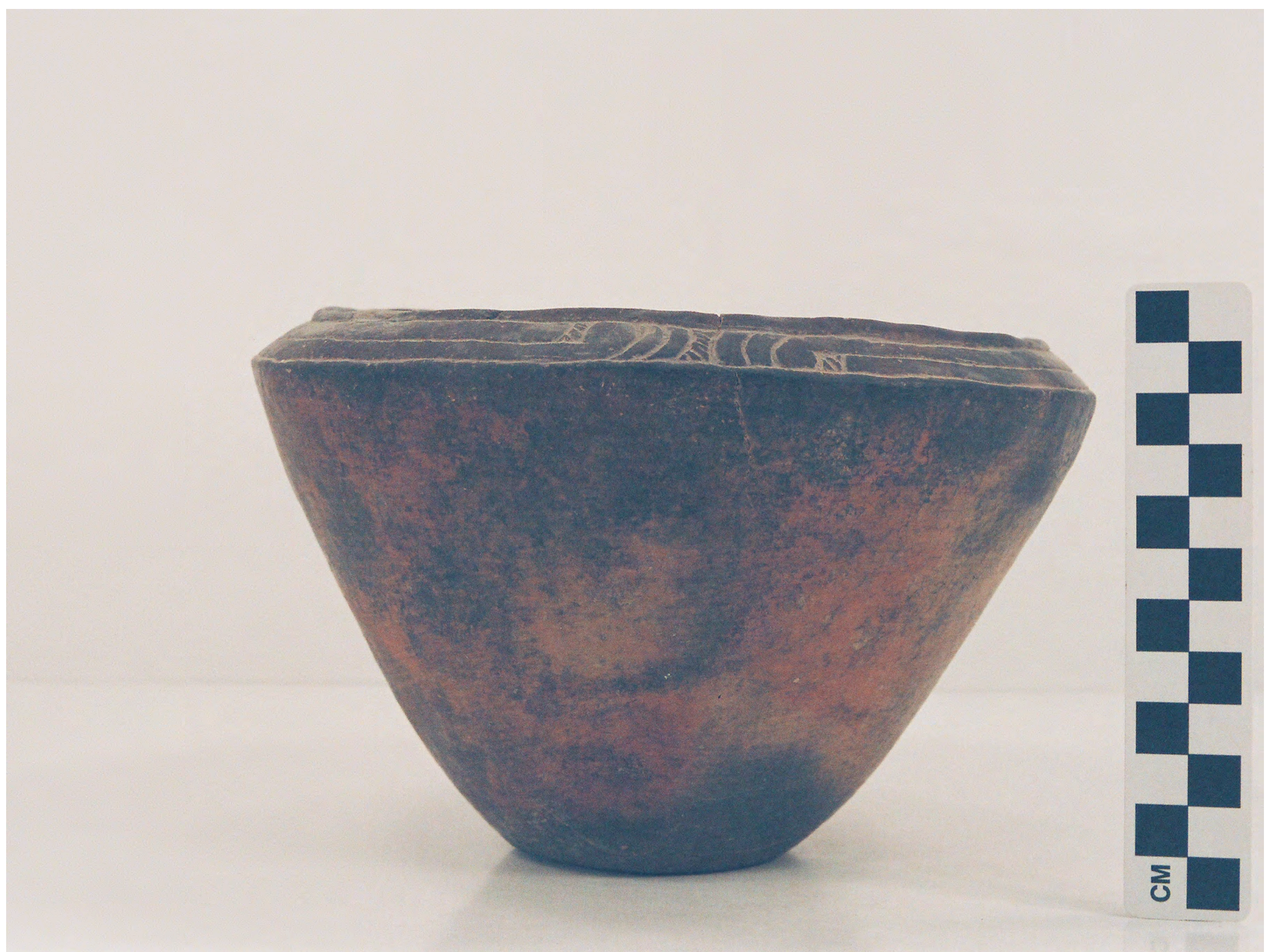

Figure 46a 


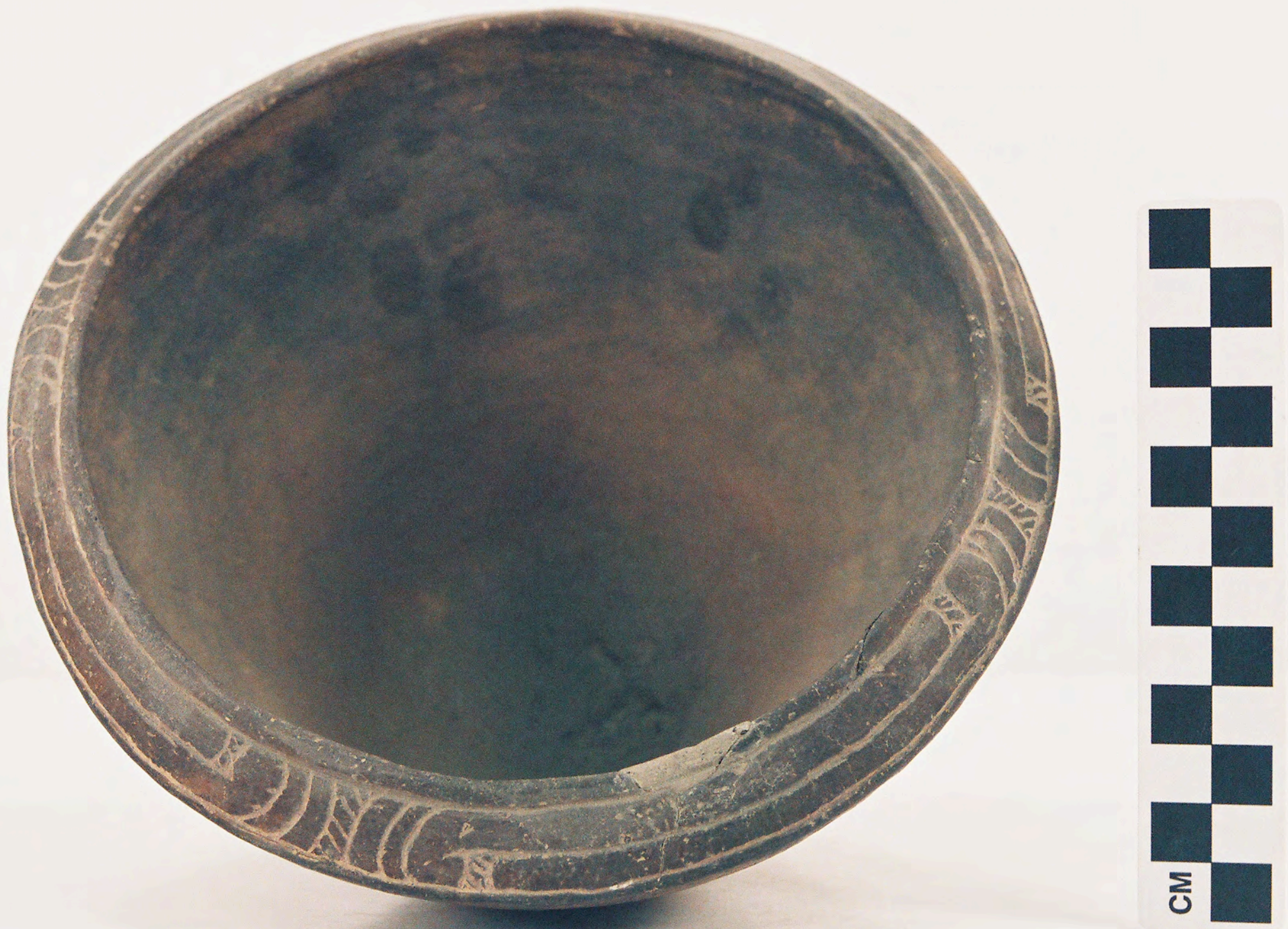

Figure 46b 


$$
\nabla
$$




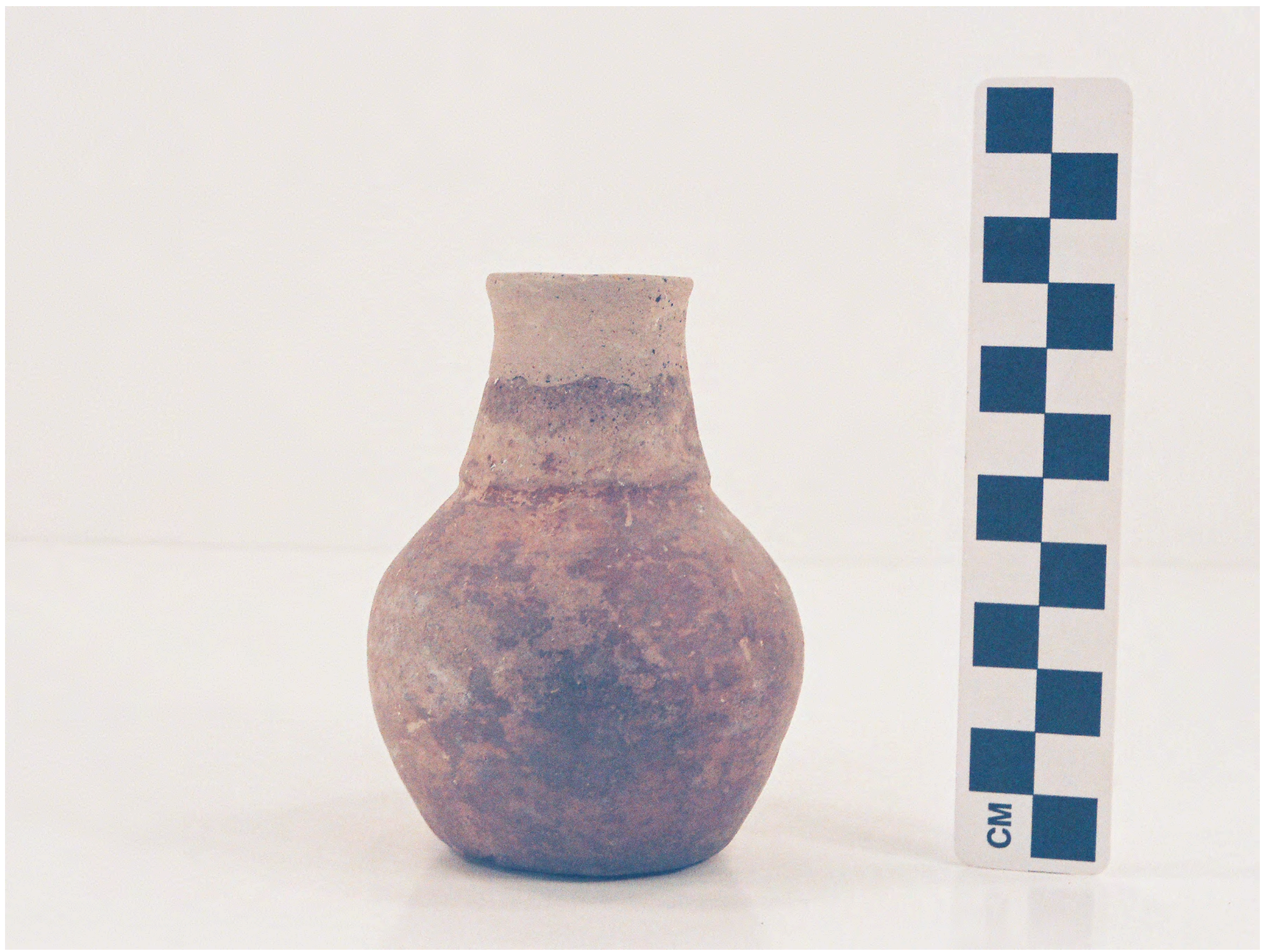

Figure 48 


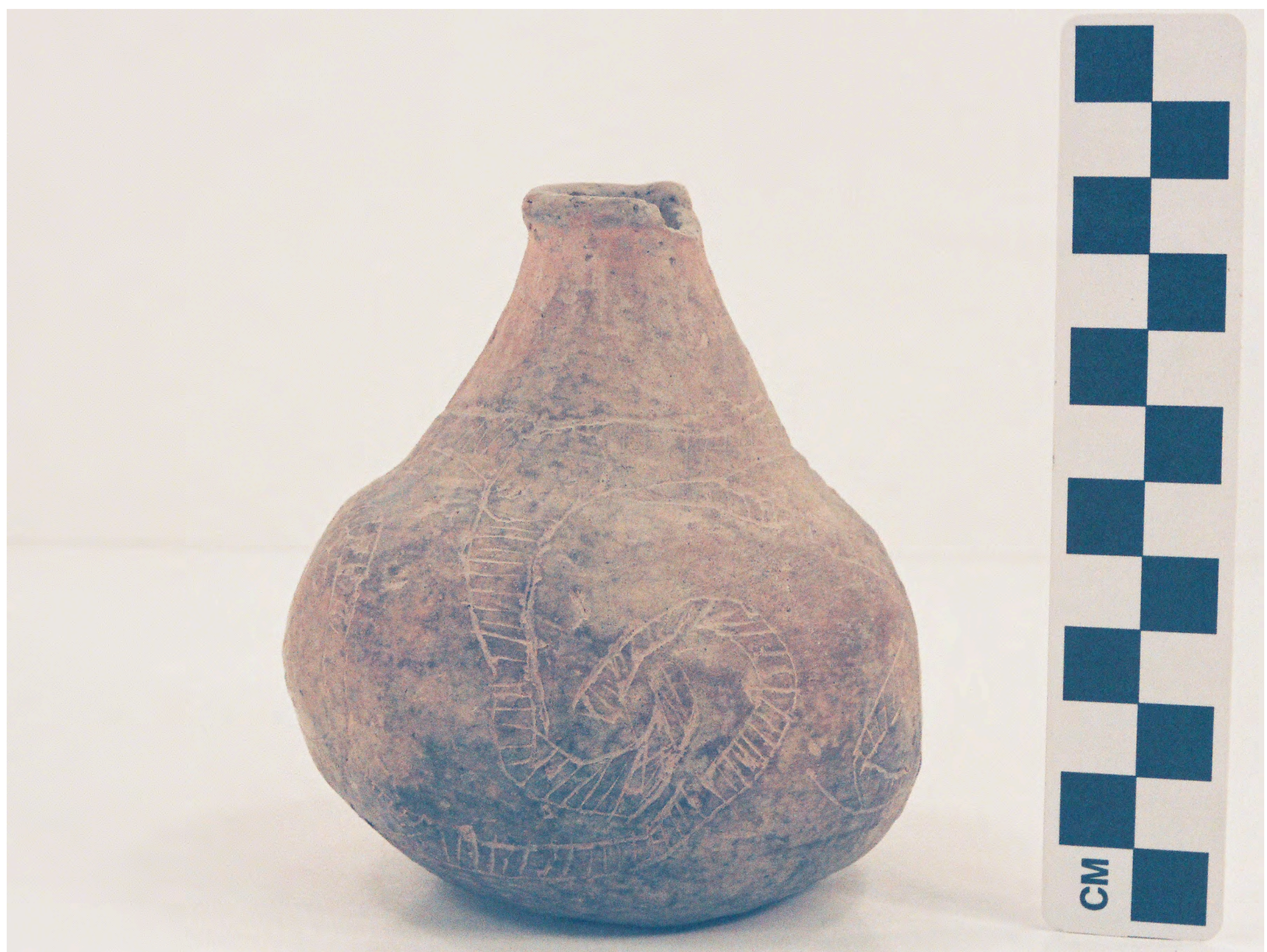

Figure 49 


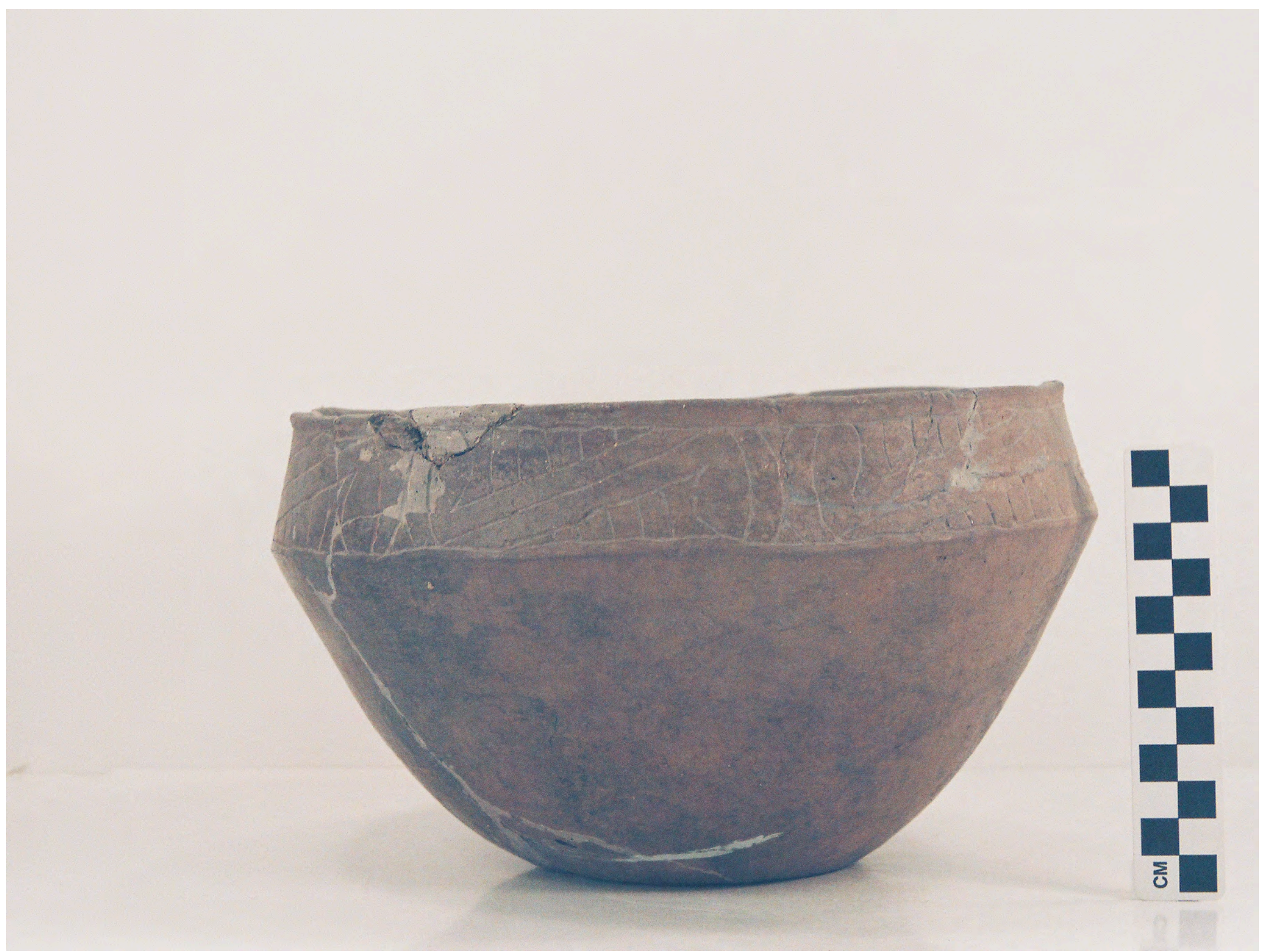

Figure 50 

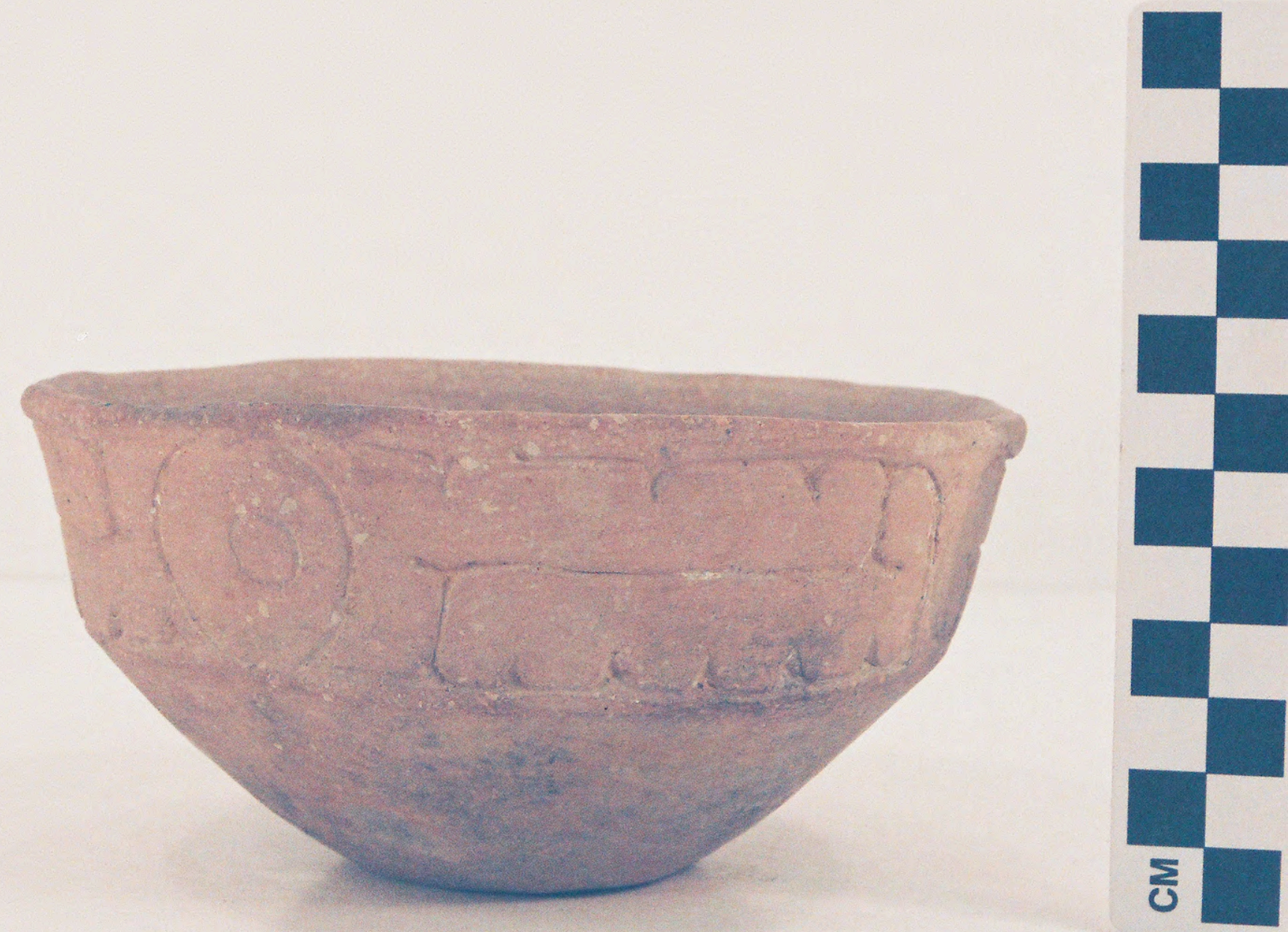

Figure 51 

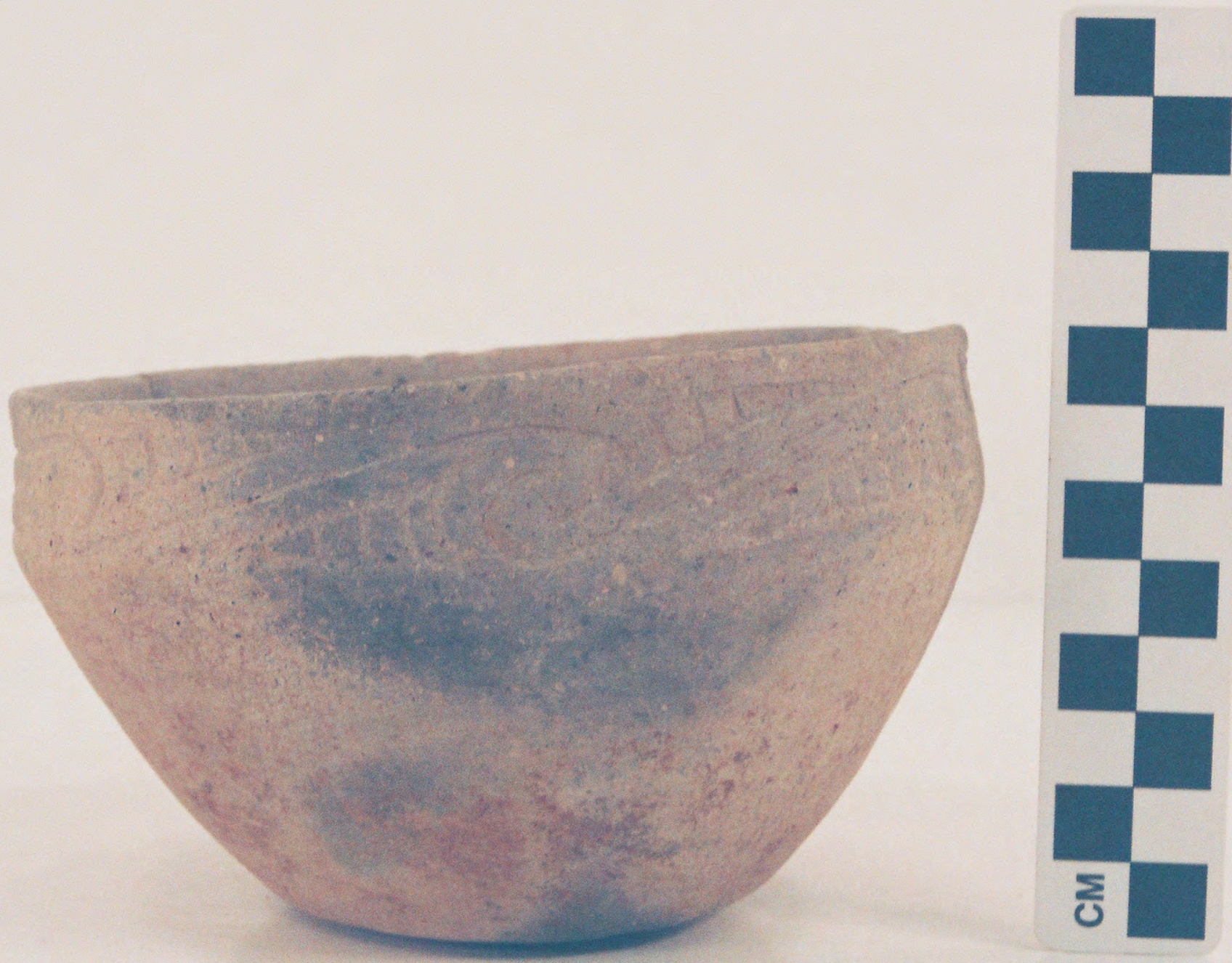

Figure 52 


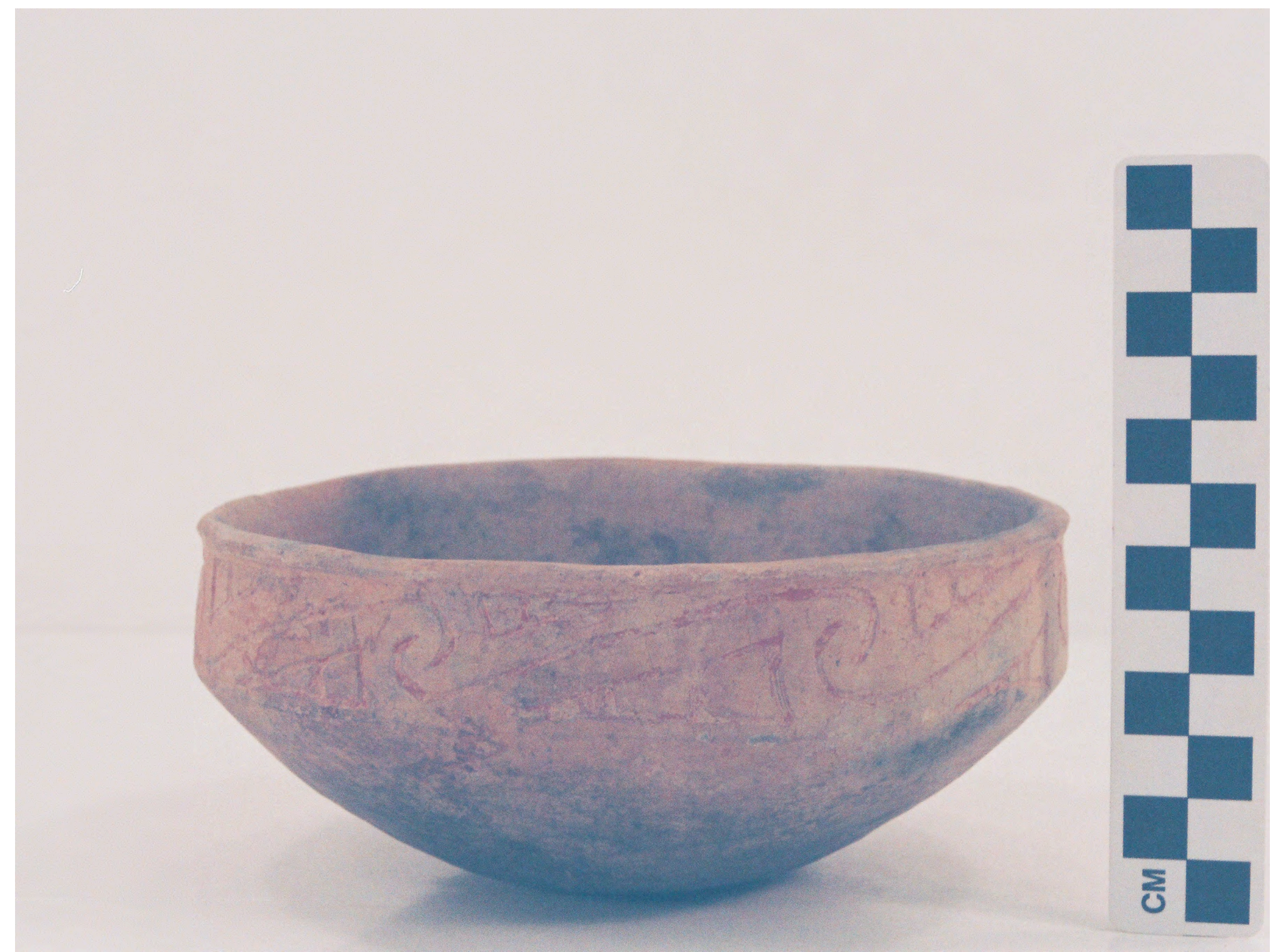

Figure 53 

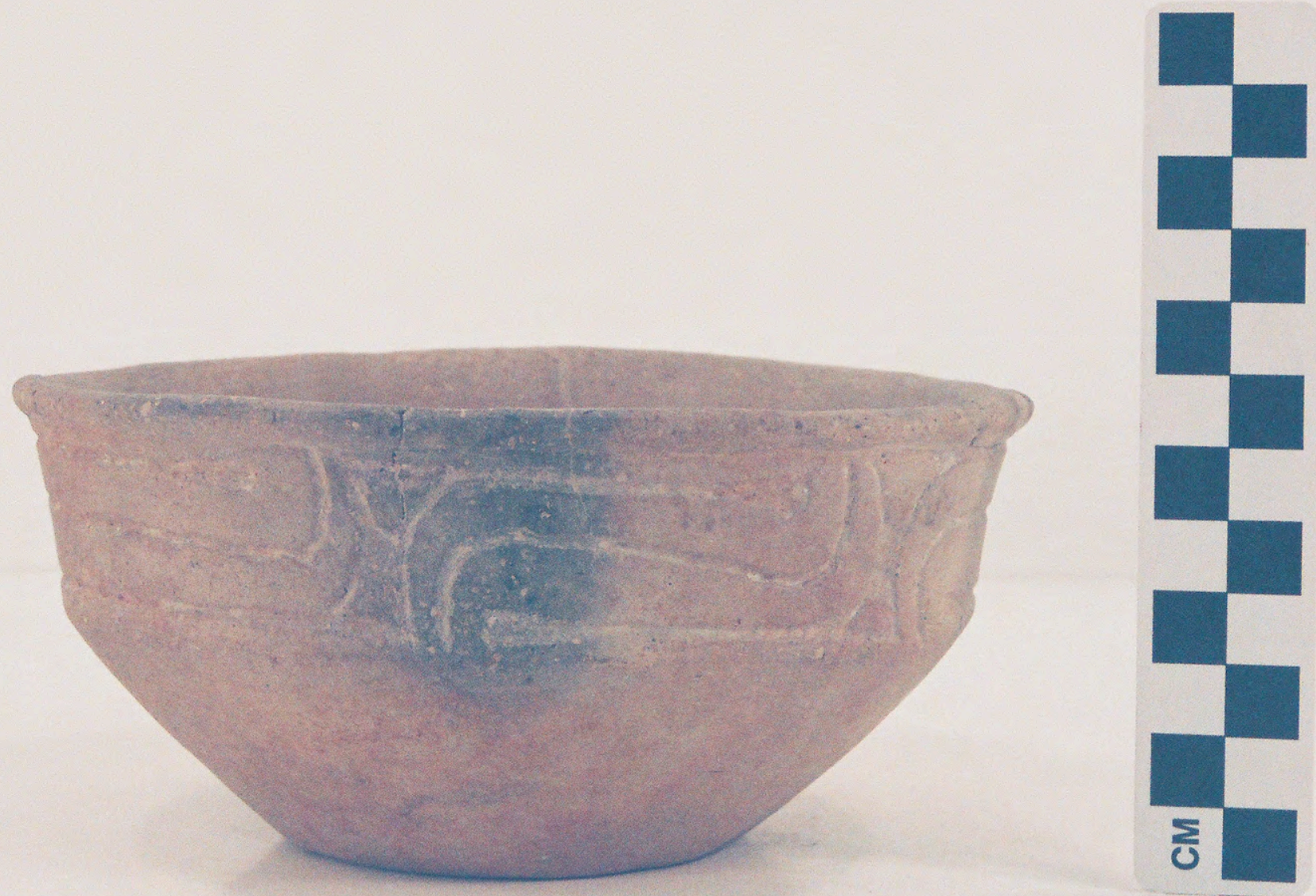

Figure 54 


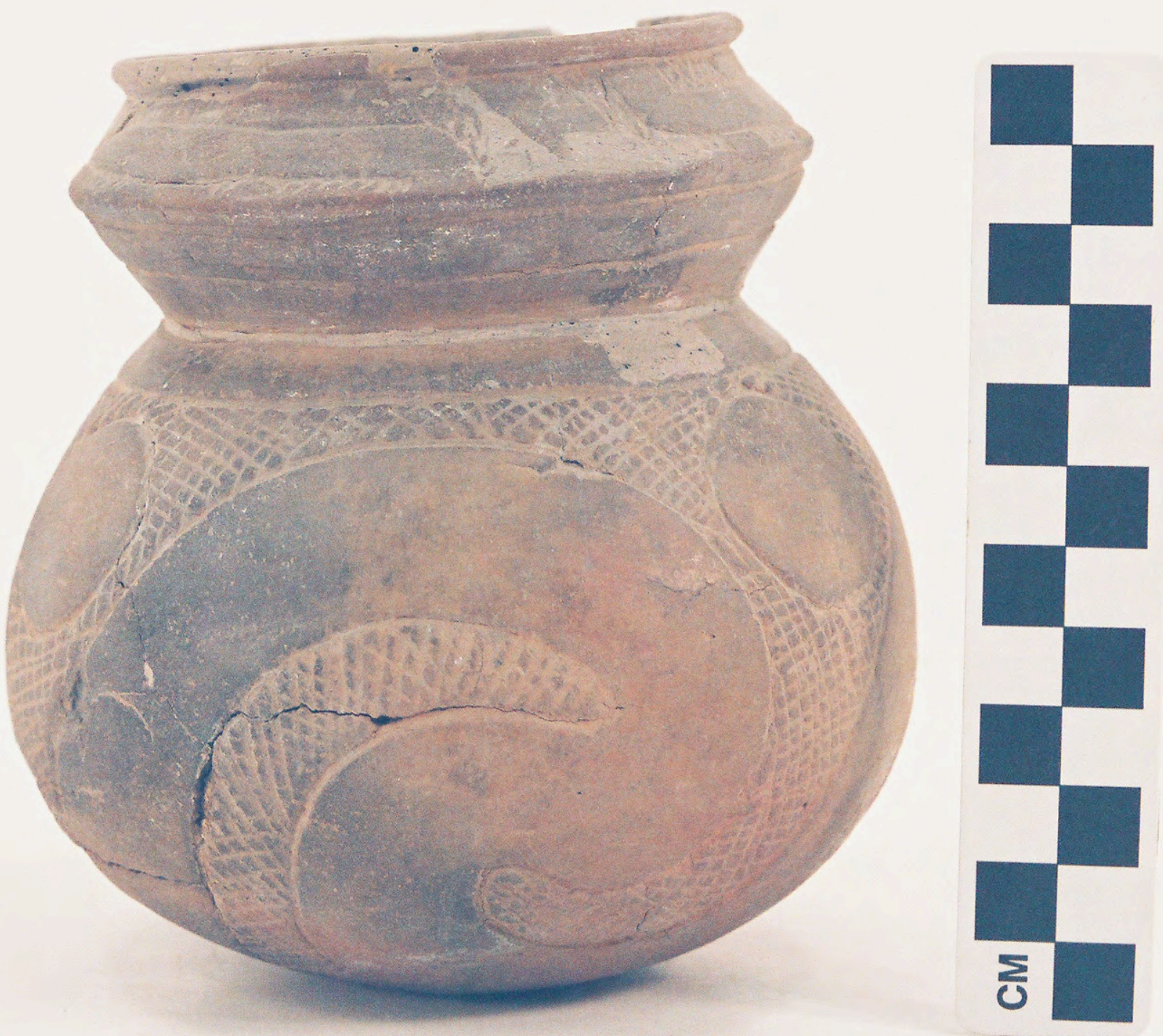

Figure 55 


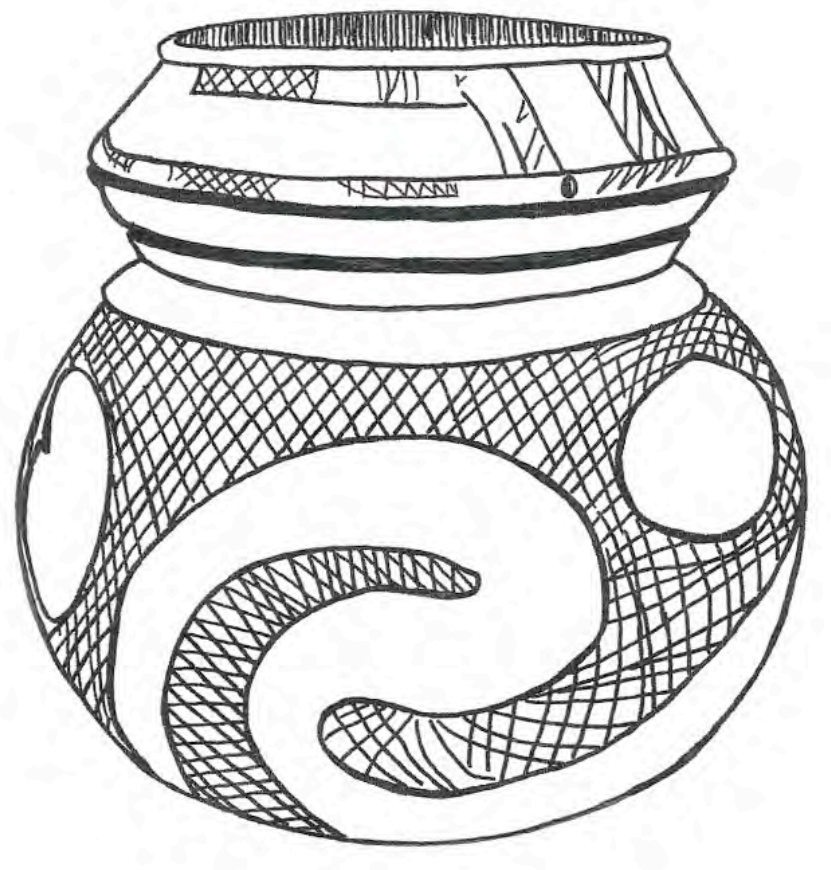

Figure 56. Drawing of Simms-Hiodges Engraved compound vessei, MR12-46: a, side view,

Figure 56a 


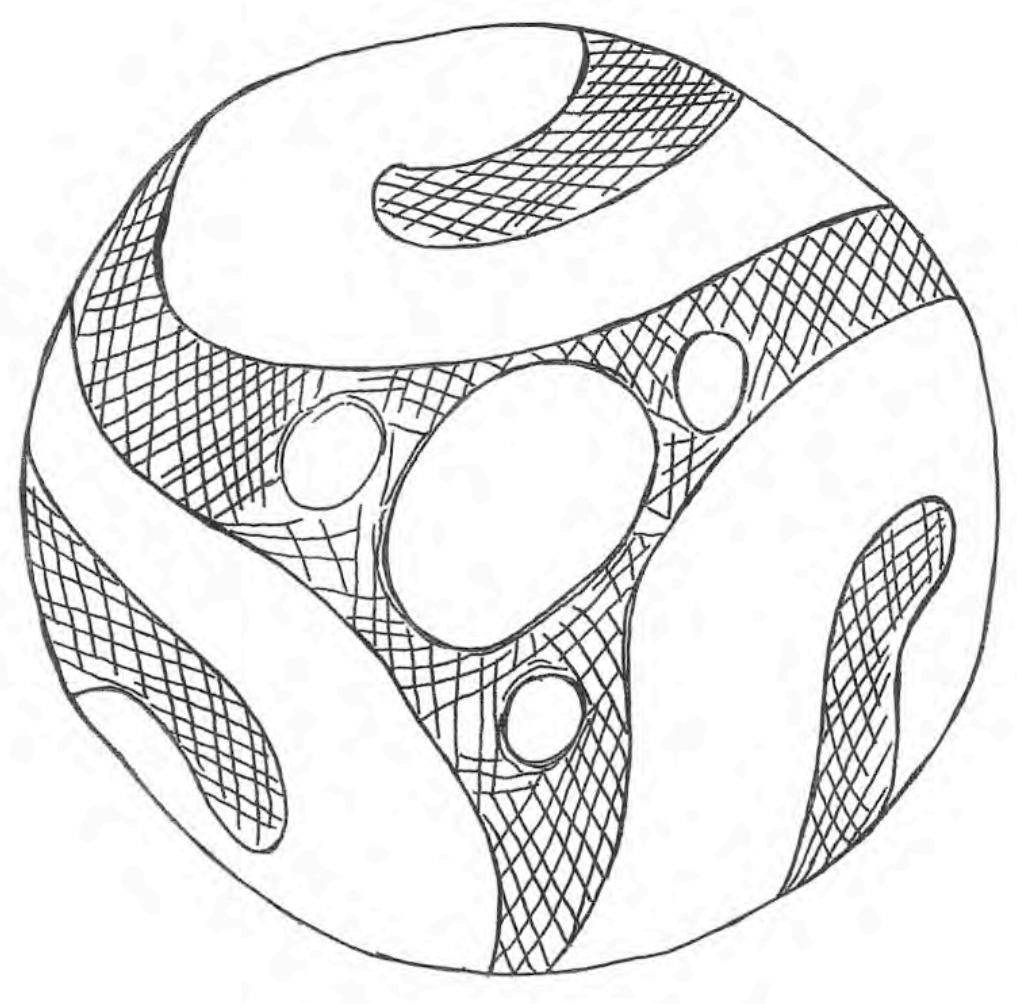

Figure 56. Drawing of Simms-Hodges Engraved compound vessei, MiRi2-46: b, showing the bottom of the Hodges Engraved portion of the vessei.

Figure 56b 


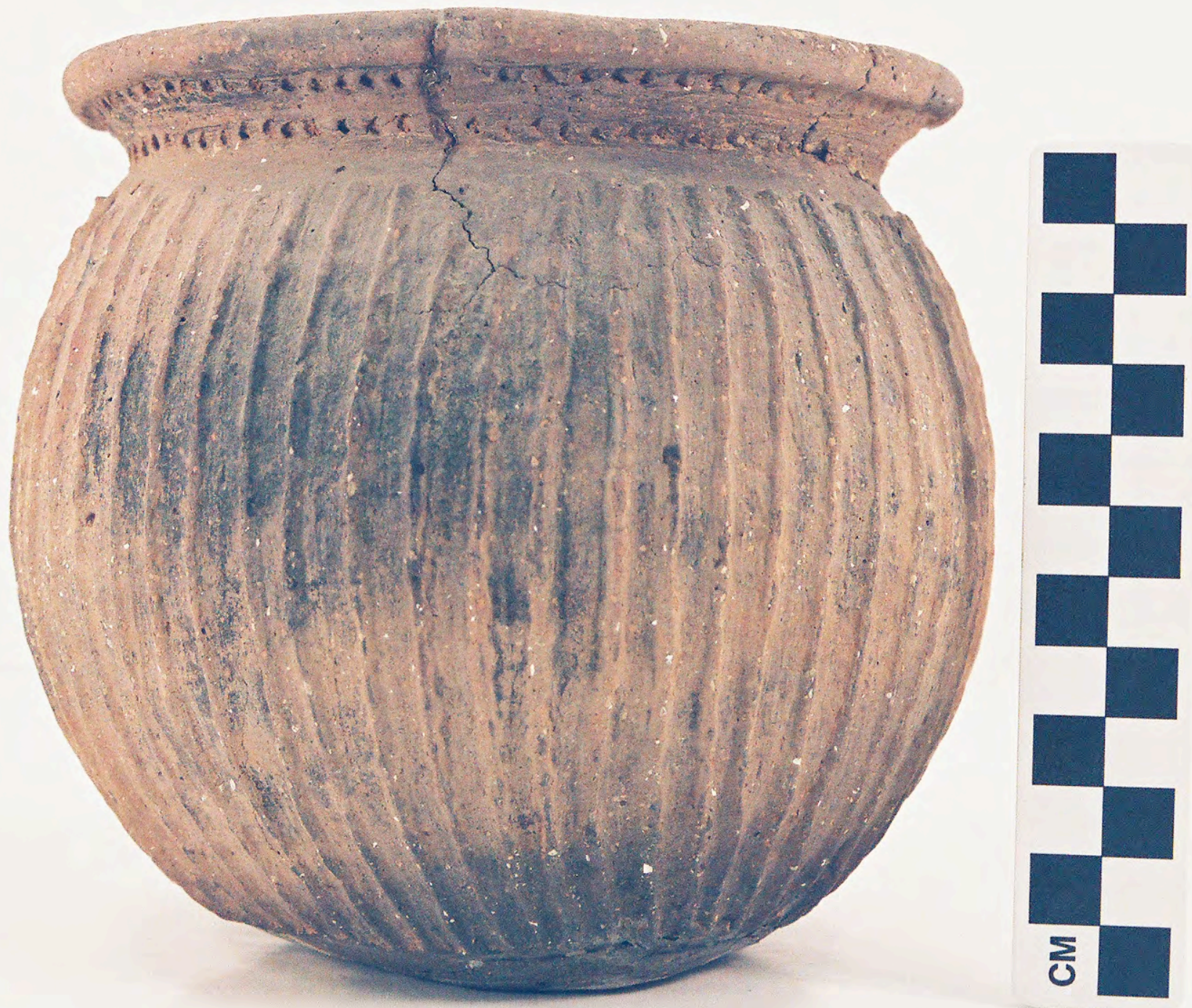

Figure 57 


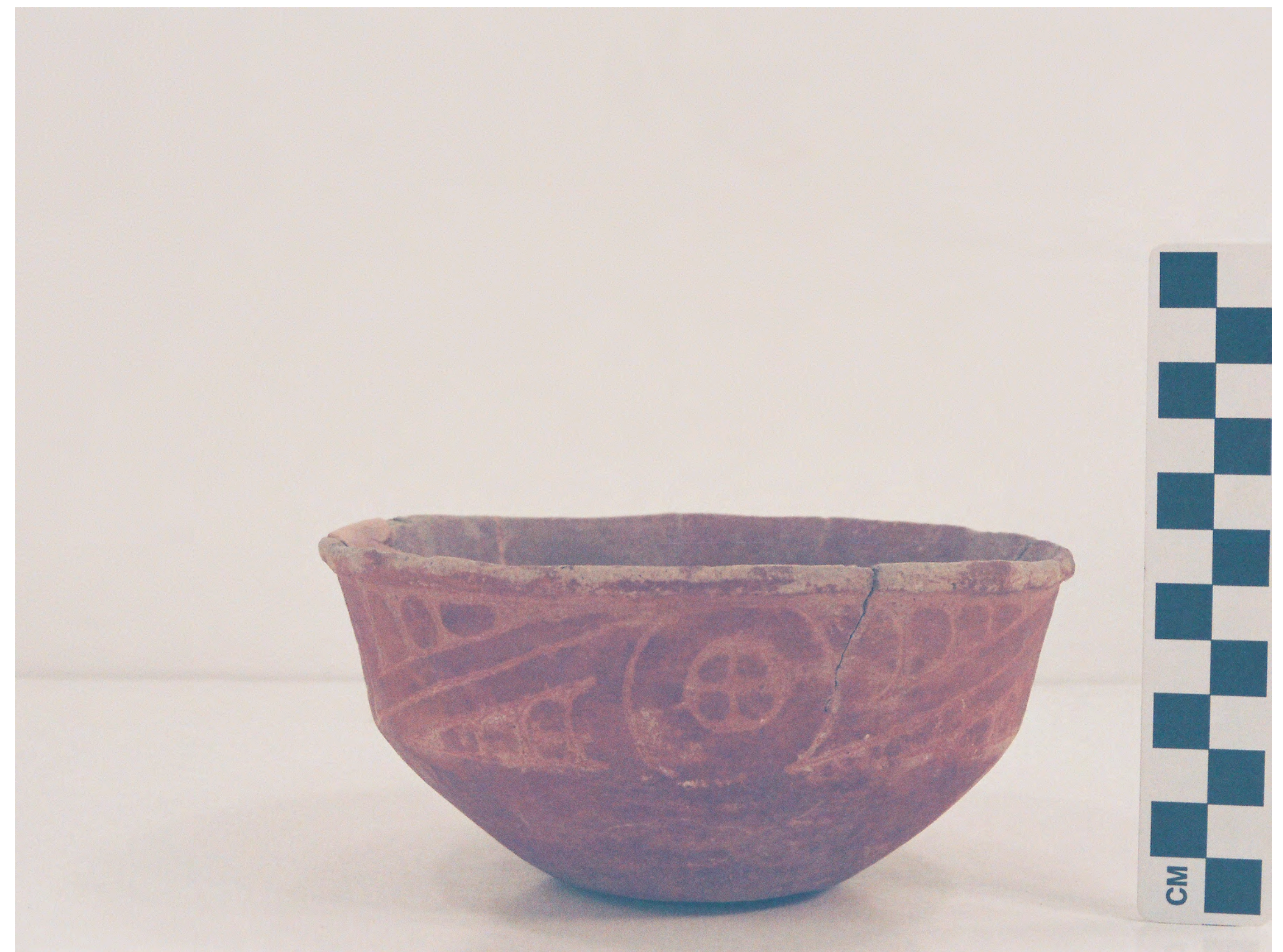

Figure 58 


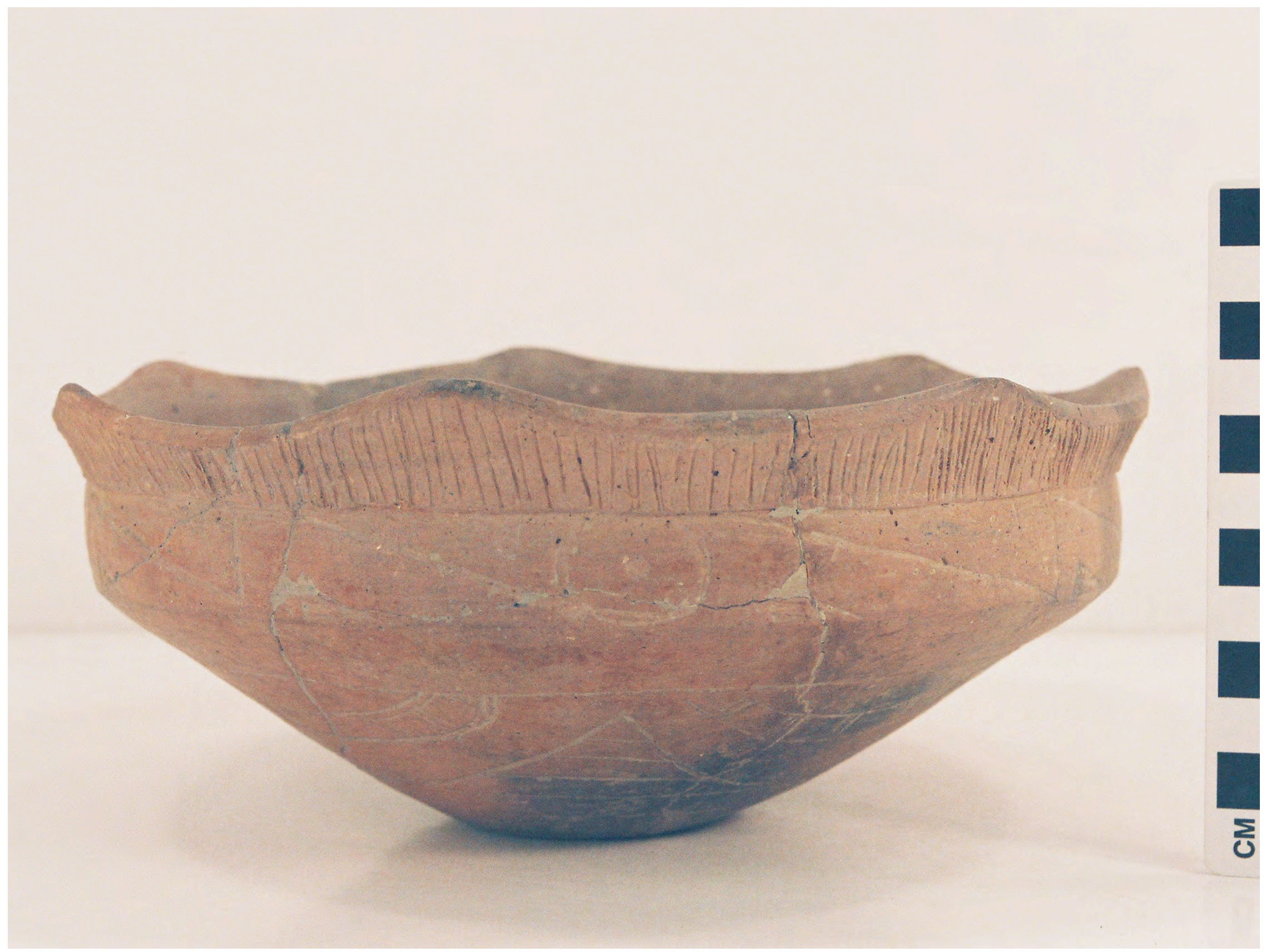

Figure 59a 


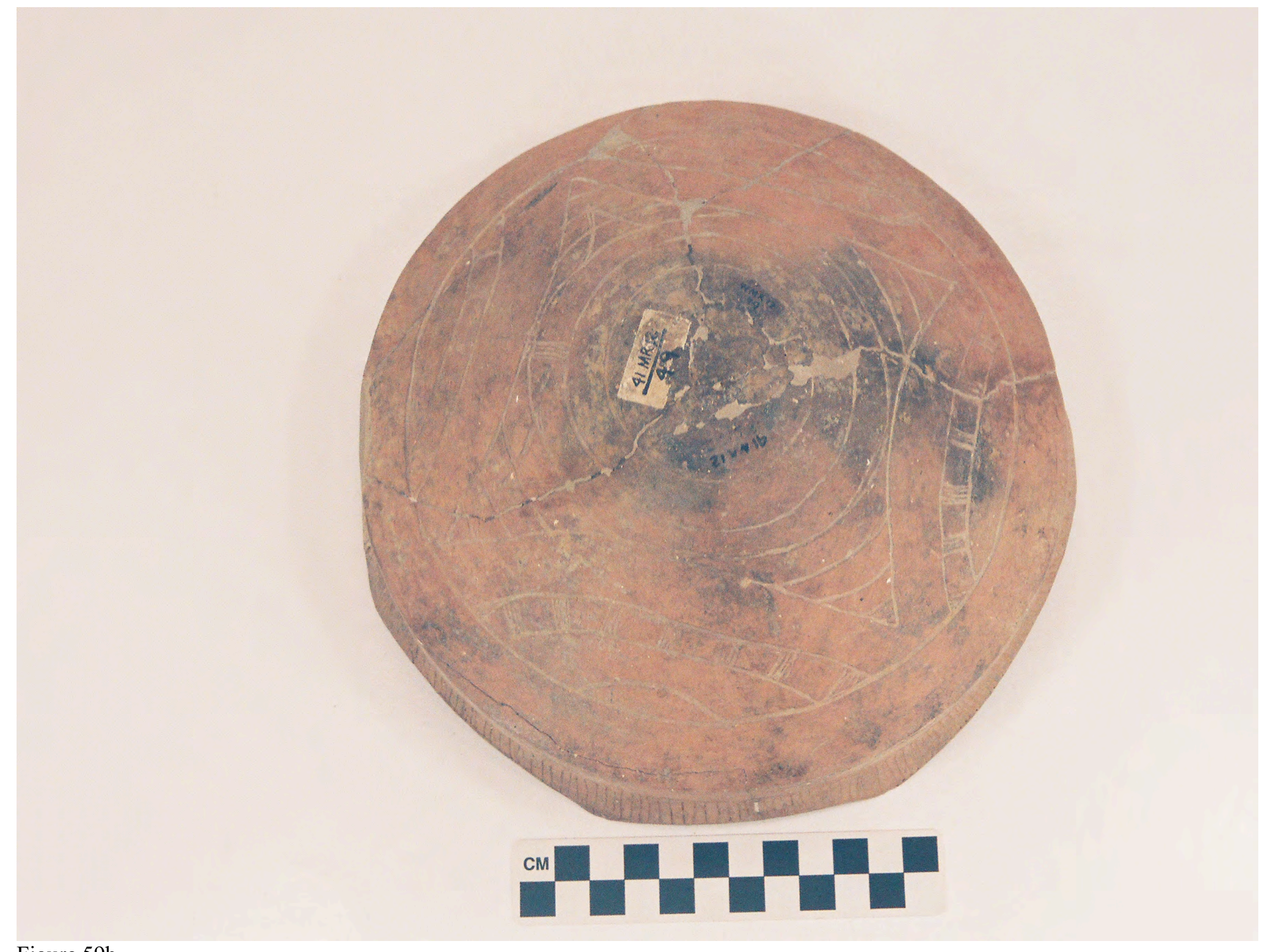

Figure 59b 


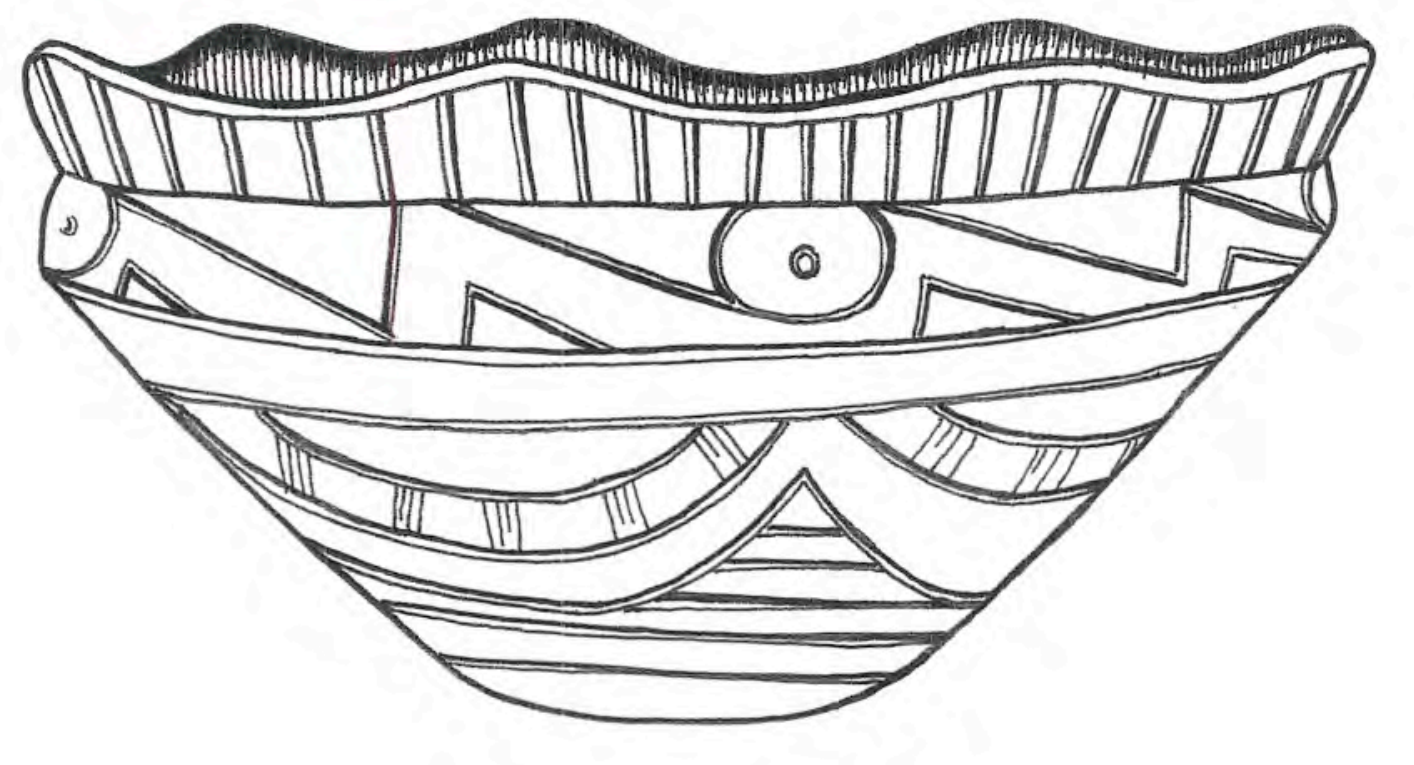

Figure 60. Drawing by Bobby Gonzalez of Ripley Engraved, var. Walkers Creek vessel: a, side view,

Figure 60a 


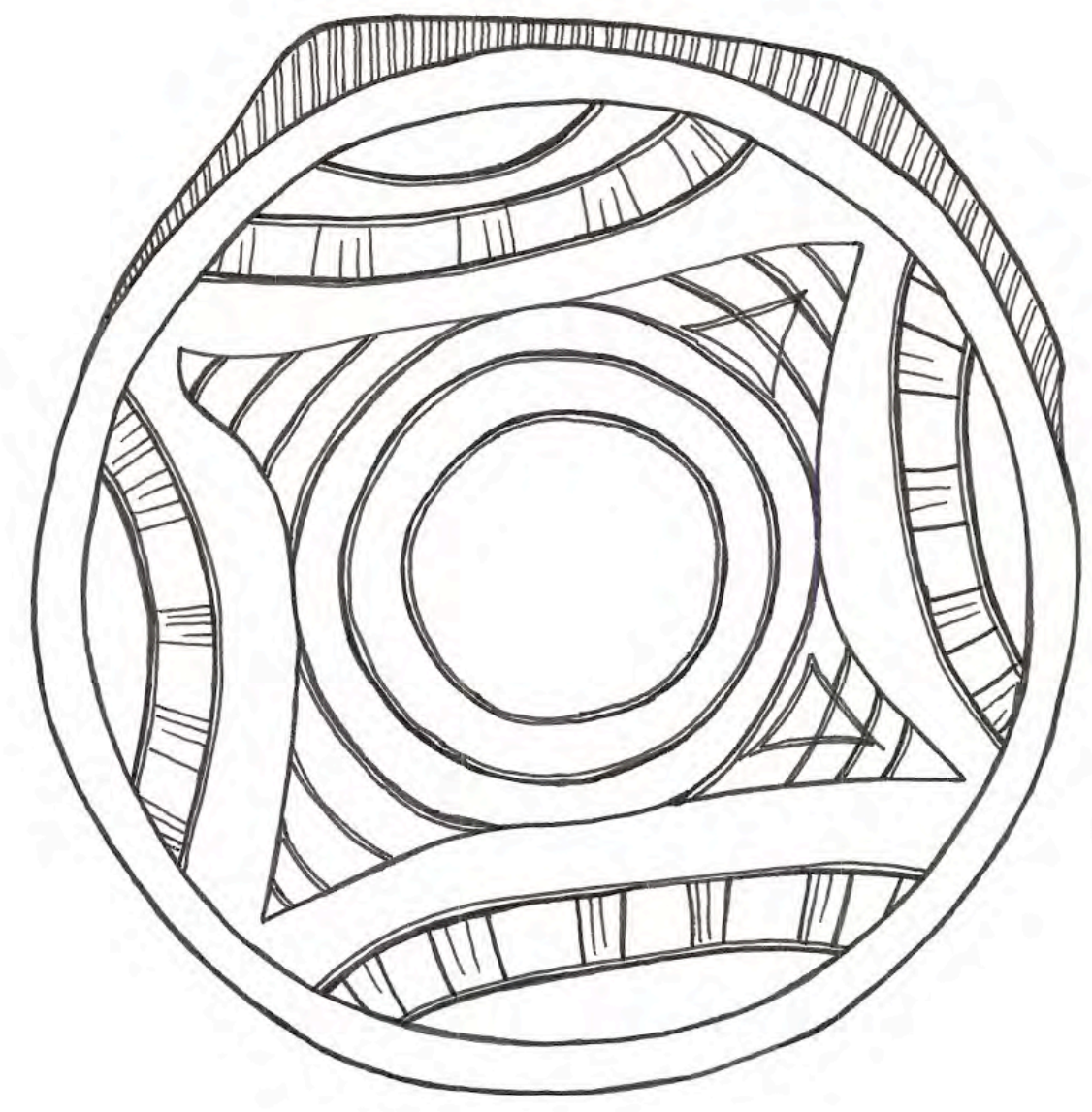

Figure 60. Drawing by Bobby Gonzalez of Ripley Engraved, var. Waikers Creek vessel b, bottom view.

Figure 60b 


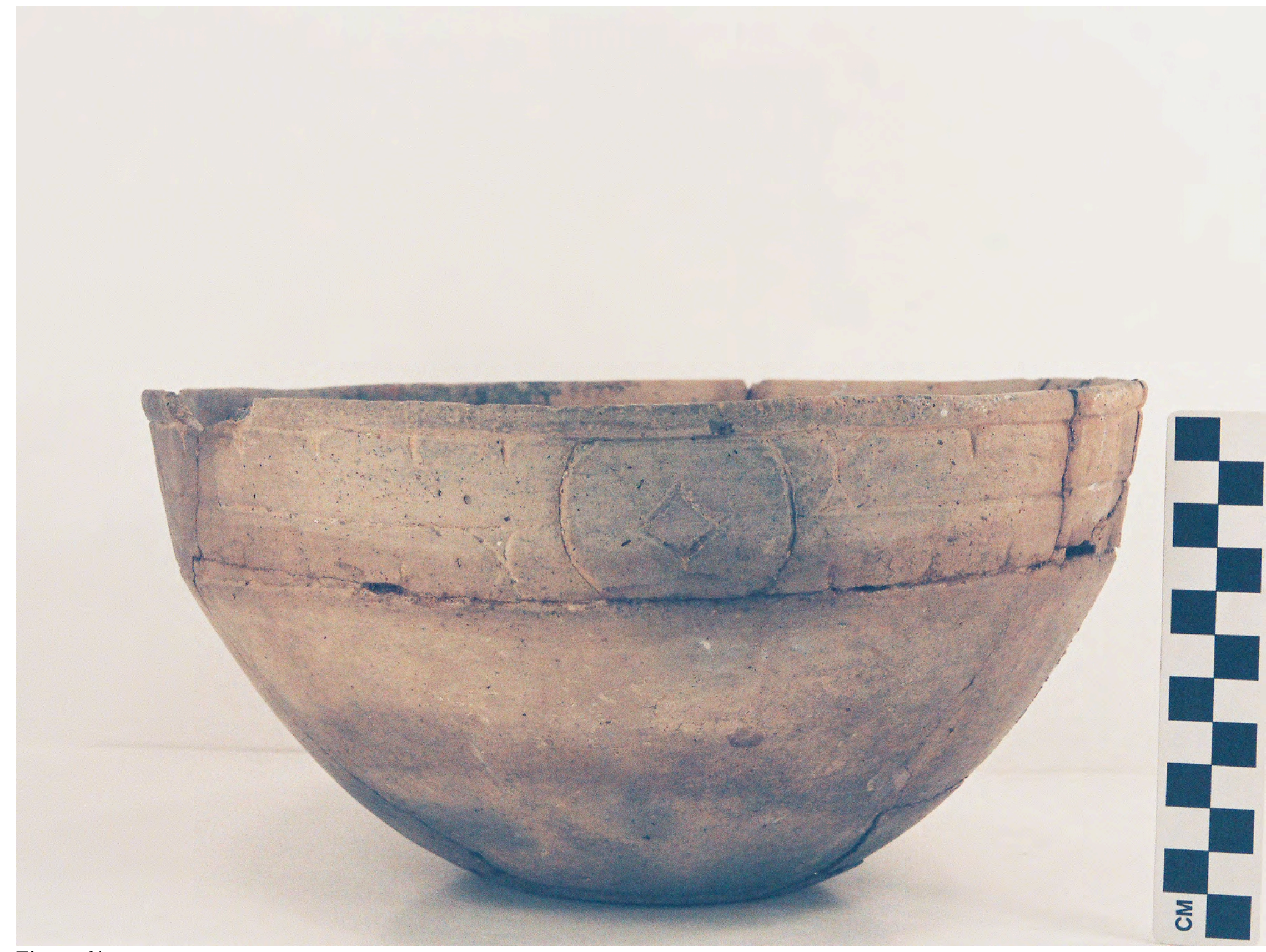

Figure 61 


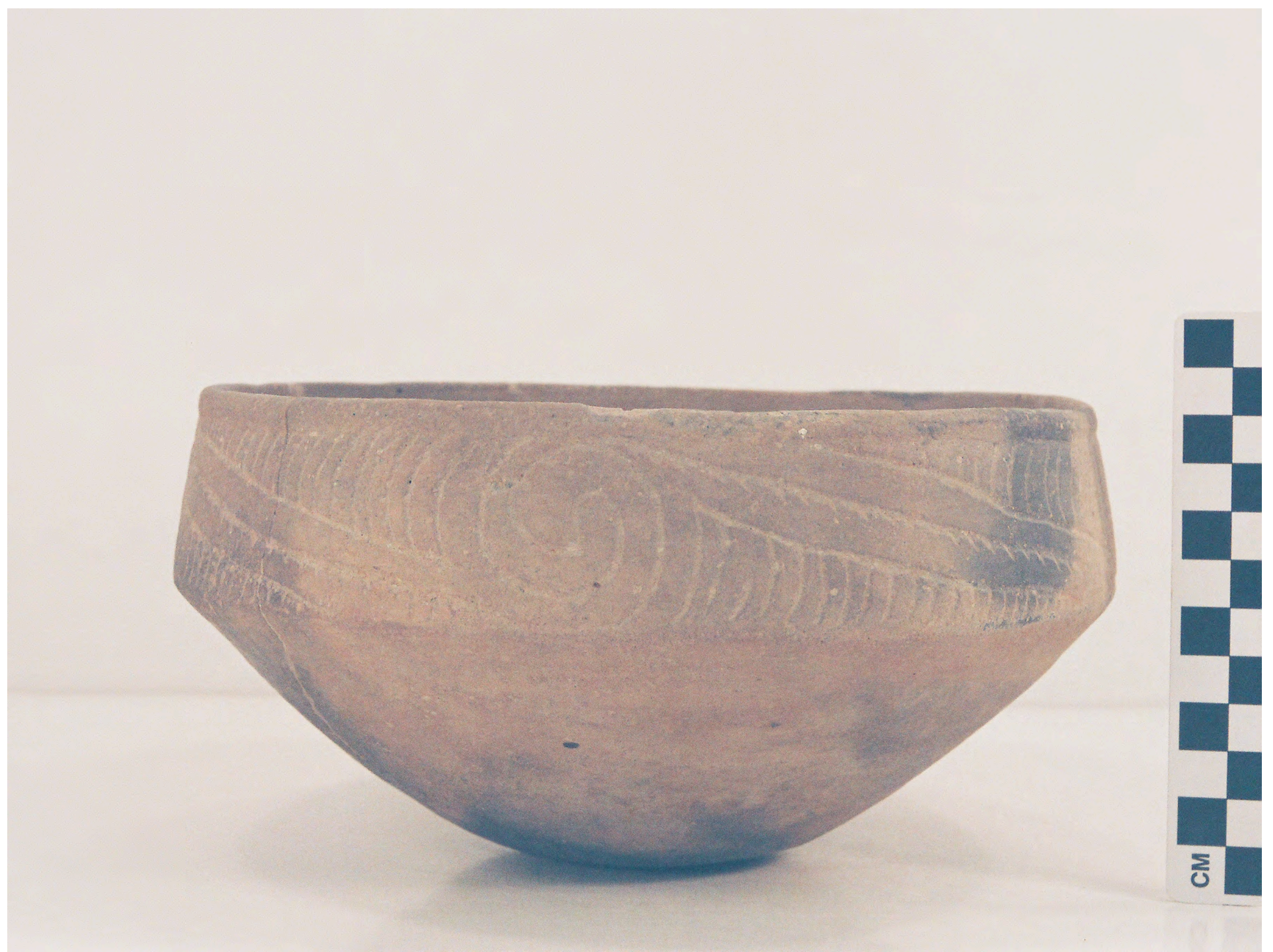

Figure 62 


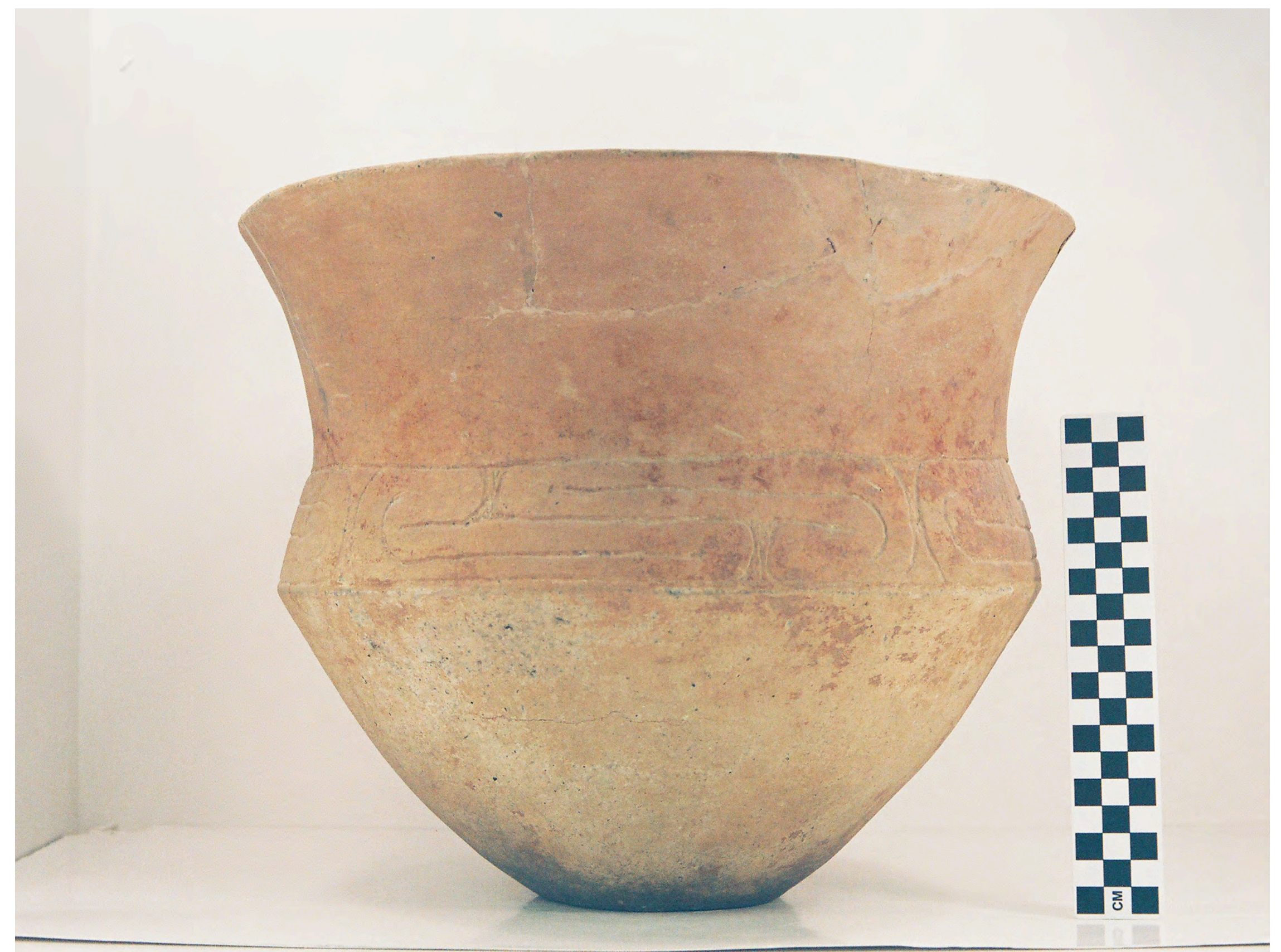

Figure 63 


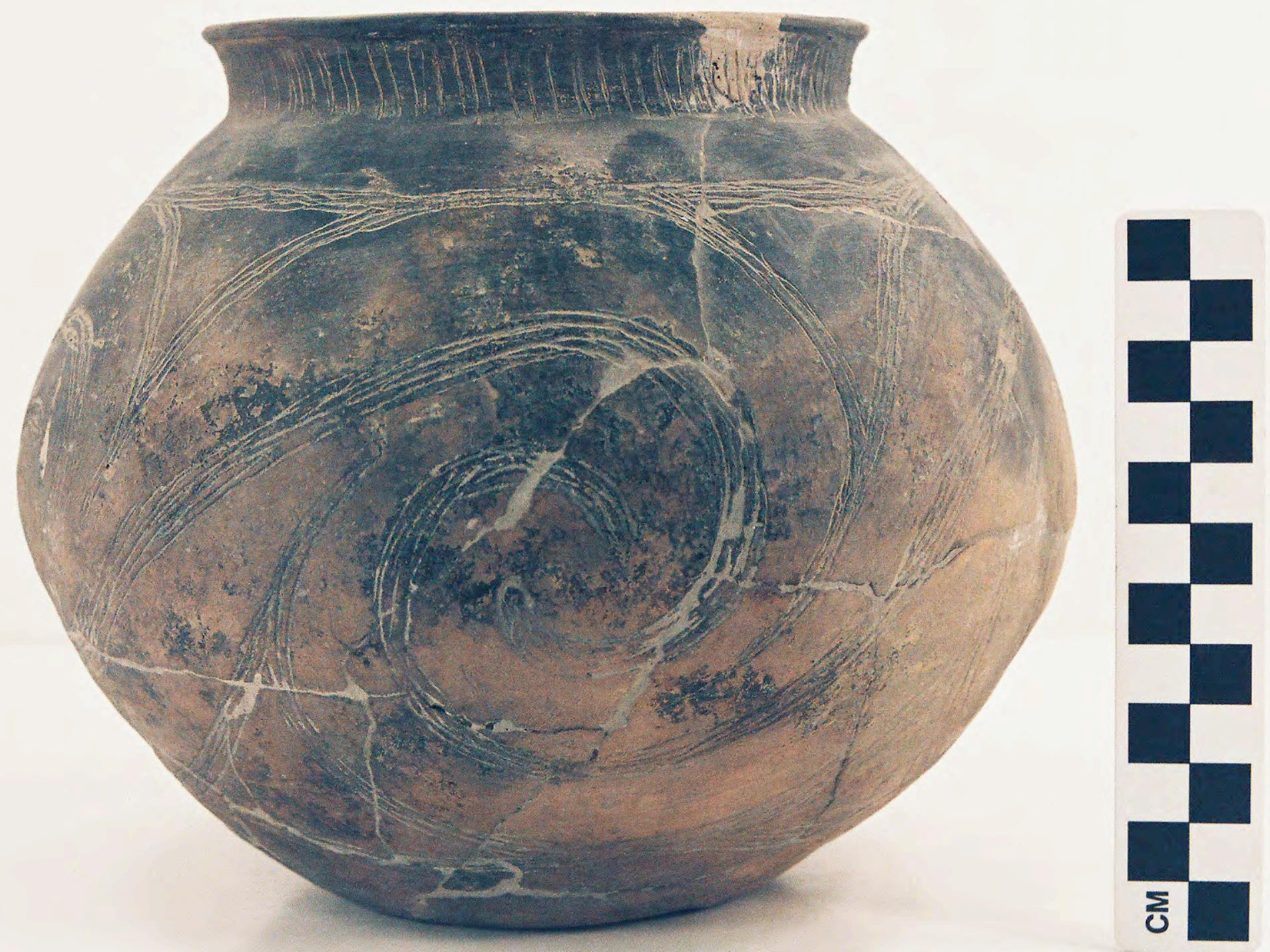

Figure 64a 


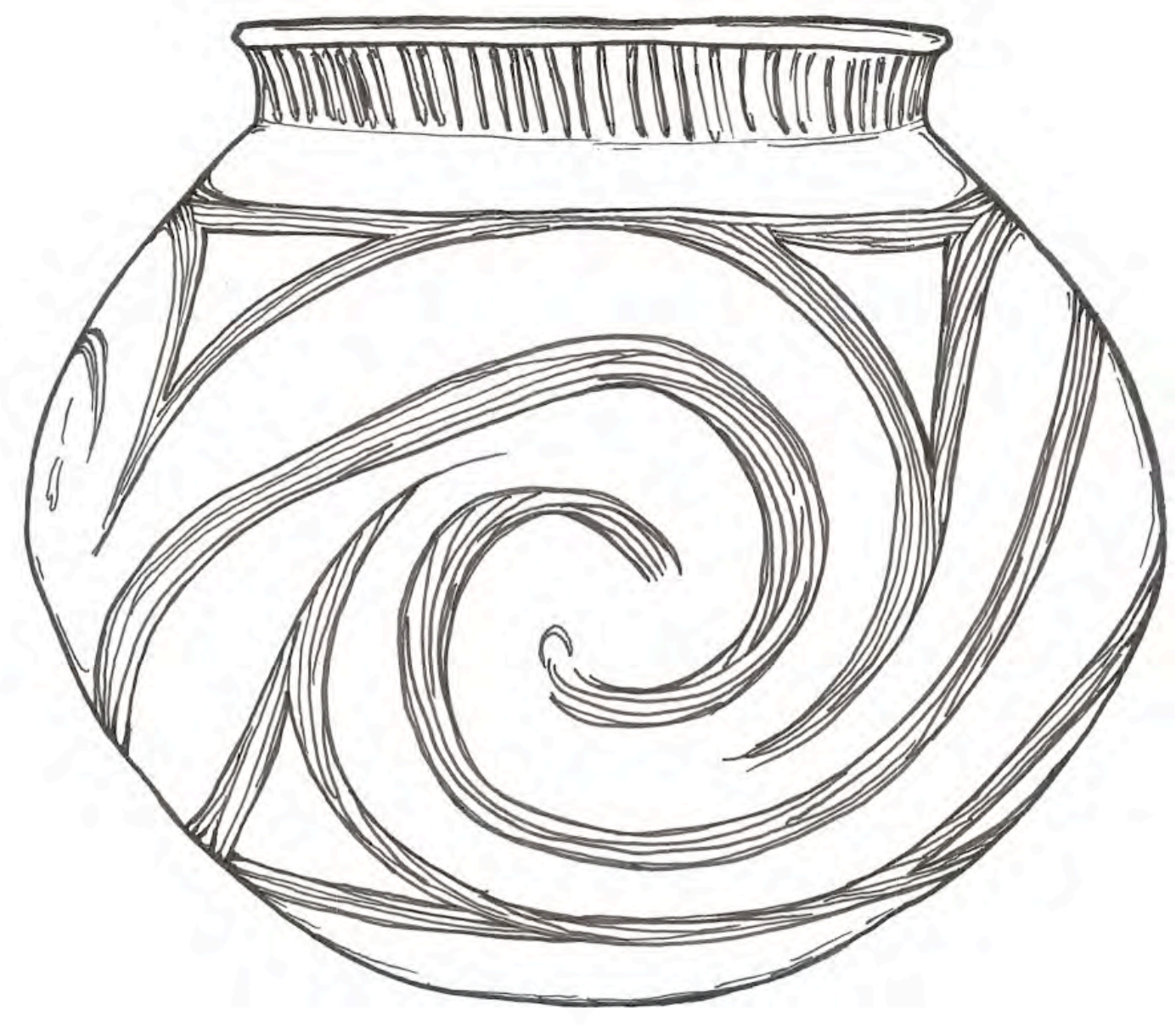

Figure 64. Engraved and incised jar, MR12-53, from Burial III at the Ben McKinney site b, drawing by Bobby Gonzalez.

Figure 64b 


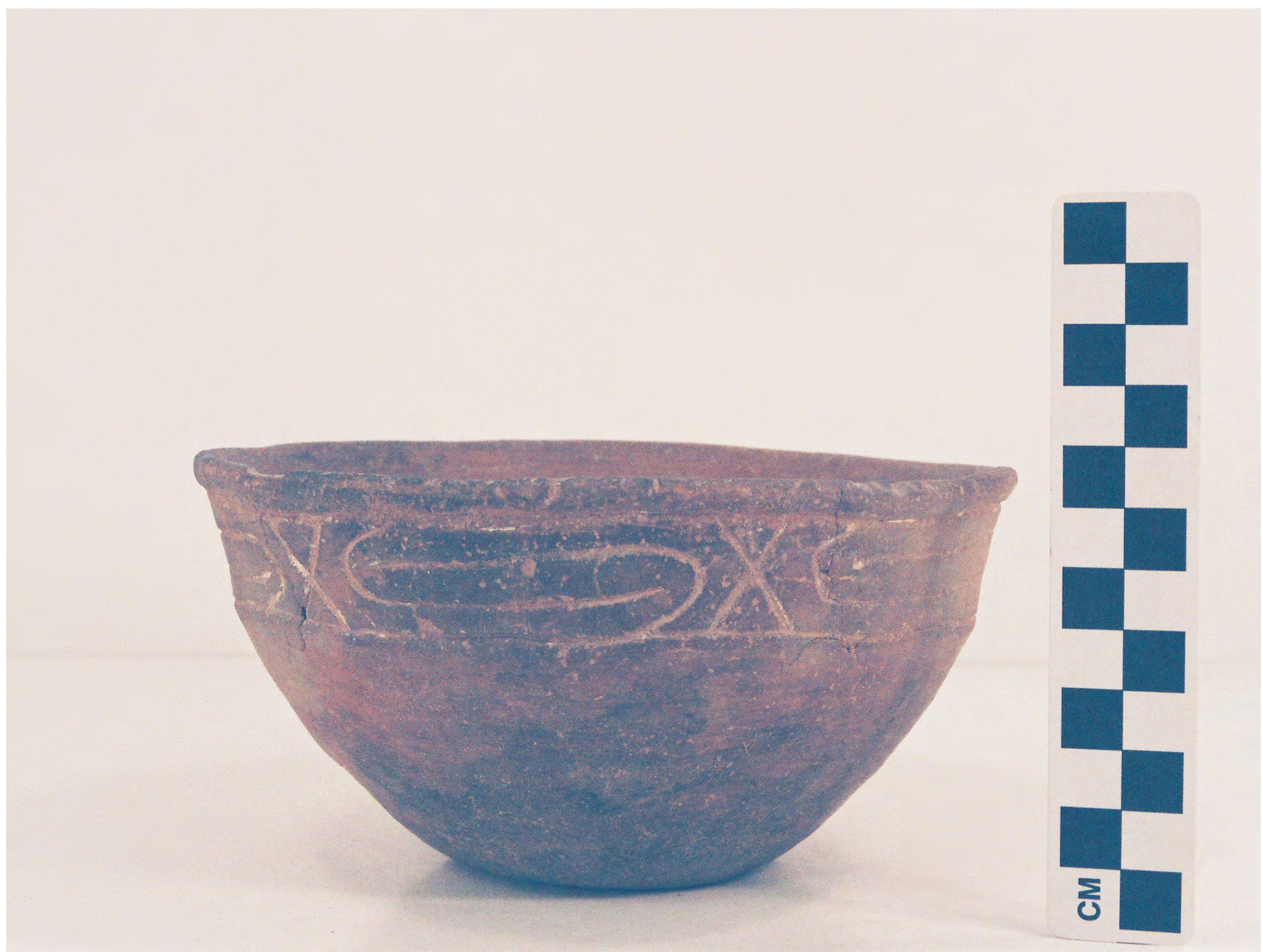

Figure 65 

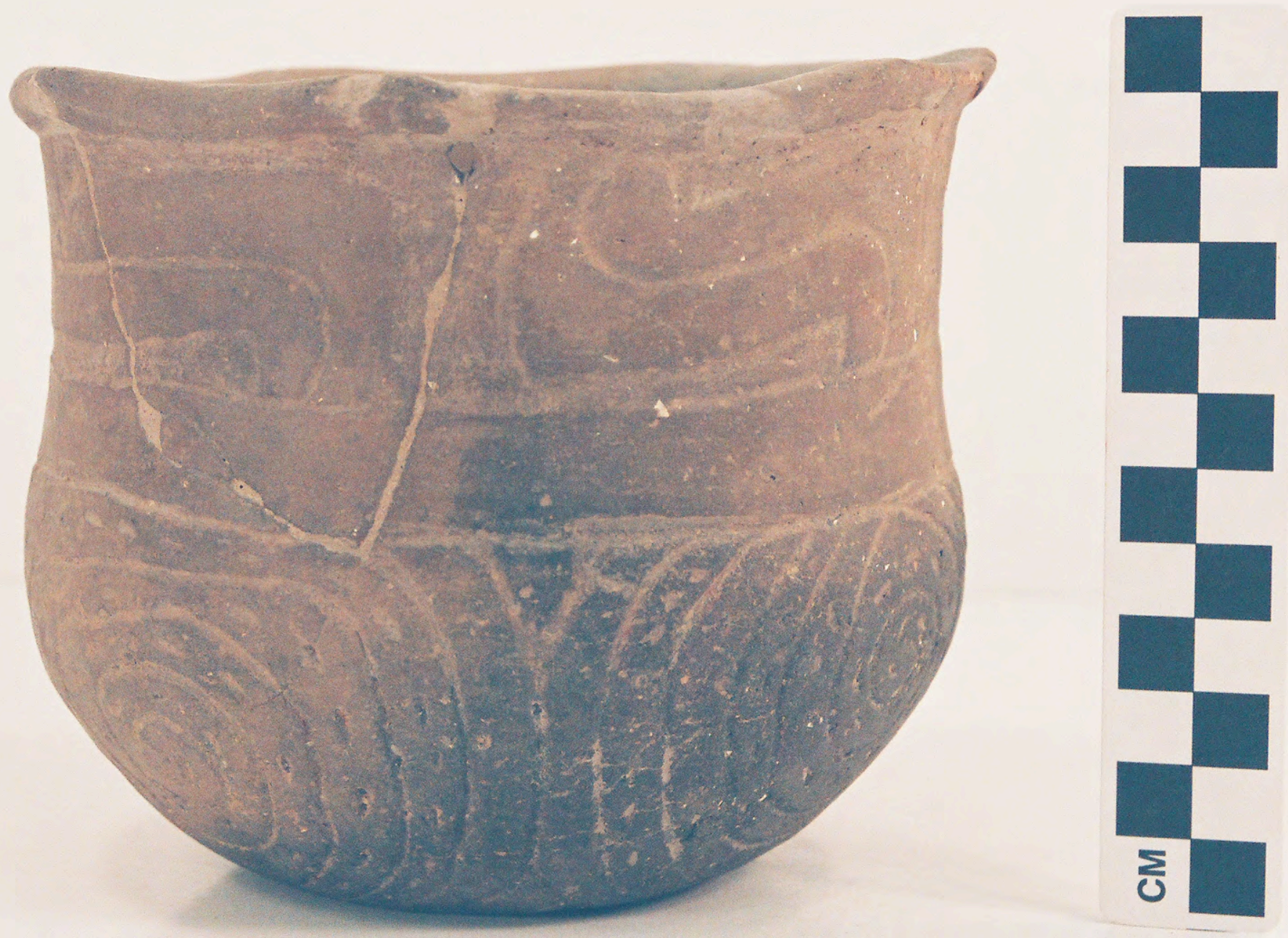

Figure 66a 


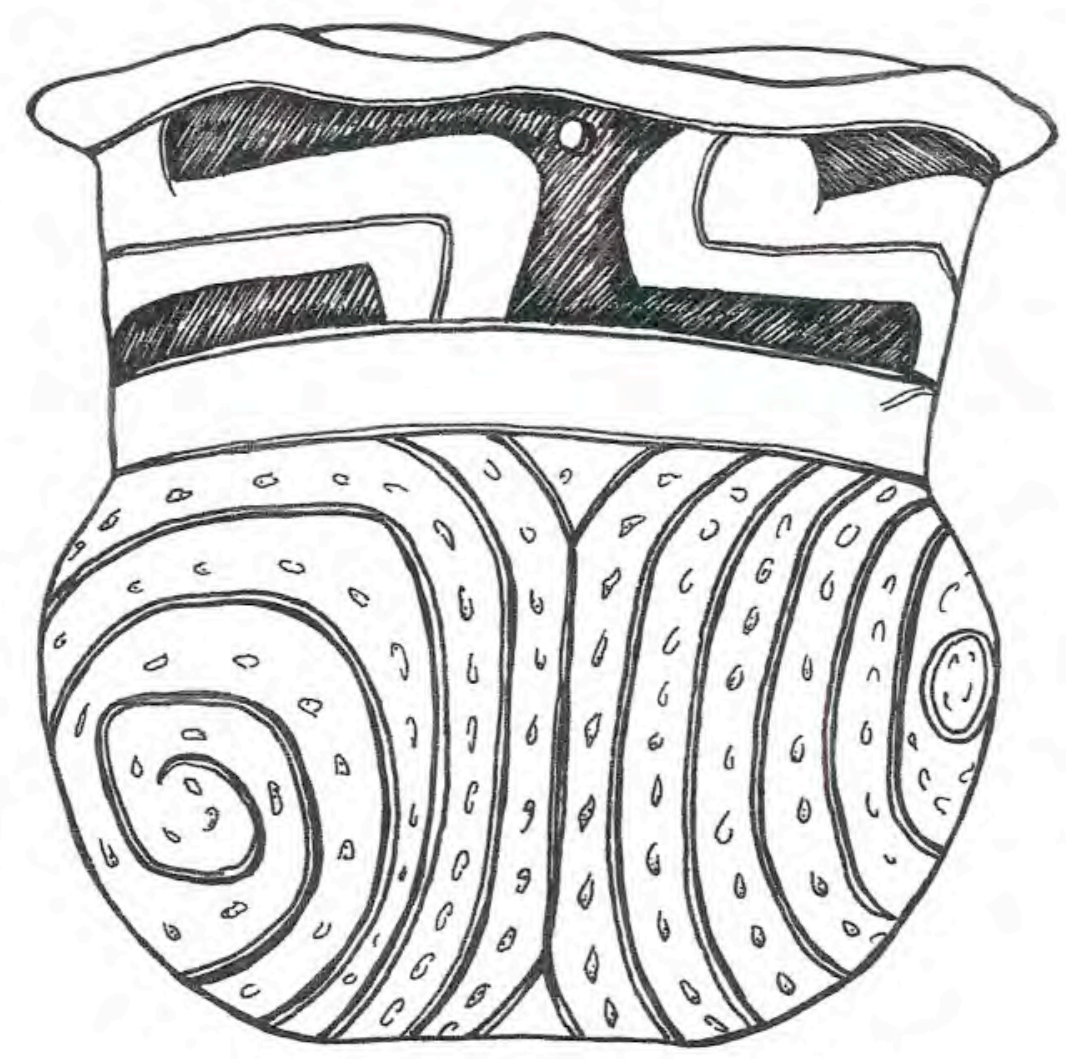

Figure 66. Vessel MR12-55, a Ripley-Taylor Engraved compound bowl from Burial I: b drawing by Bobby Gonzalez.

Figure $66 \mathrm{~b}$ 


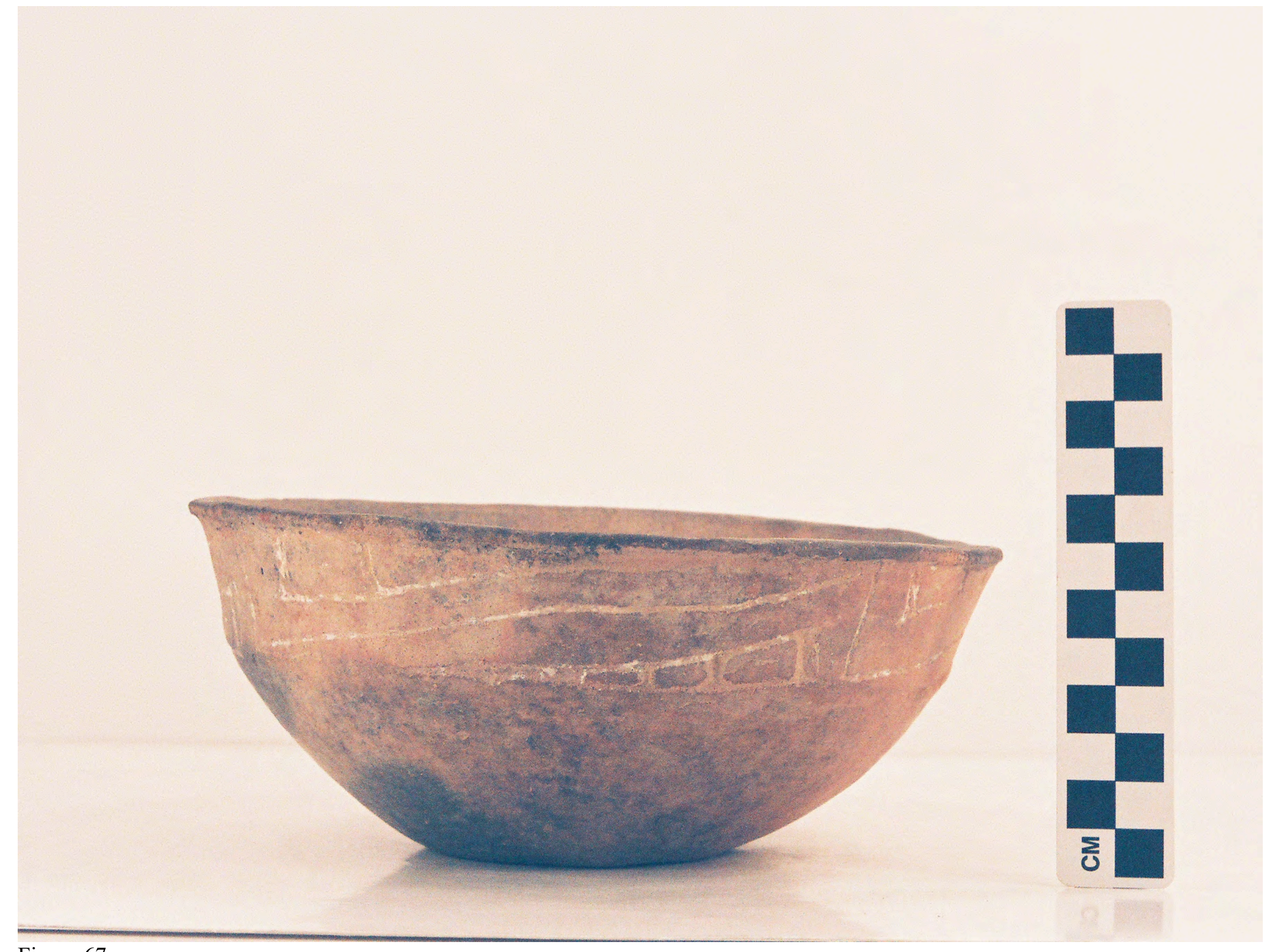

Figure 67 


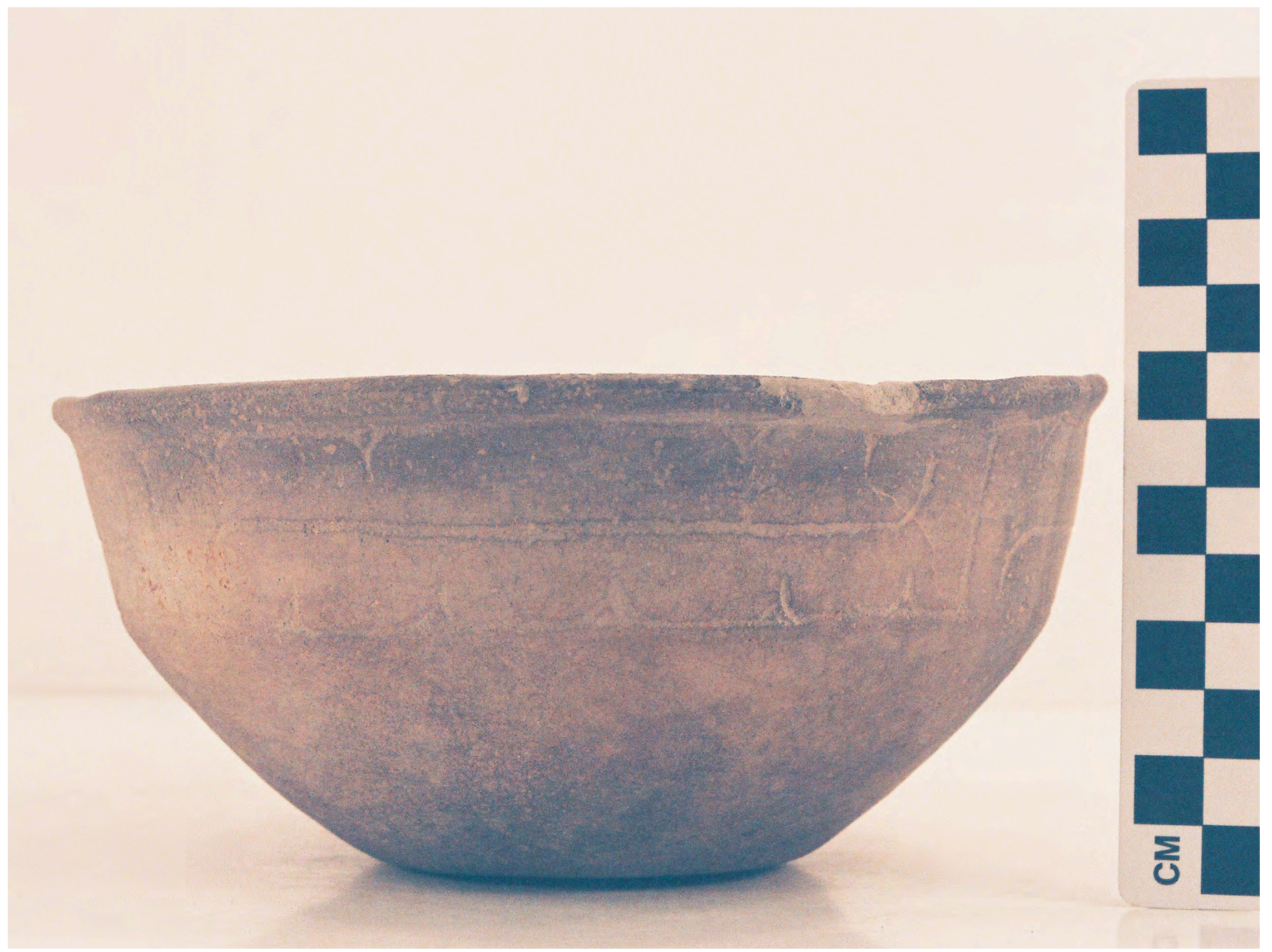

Figure 68 


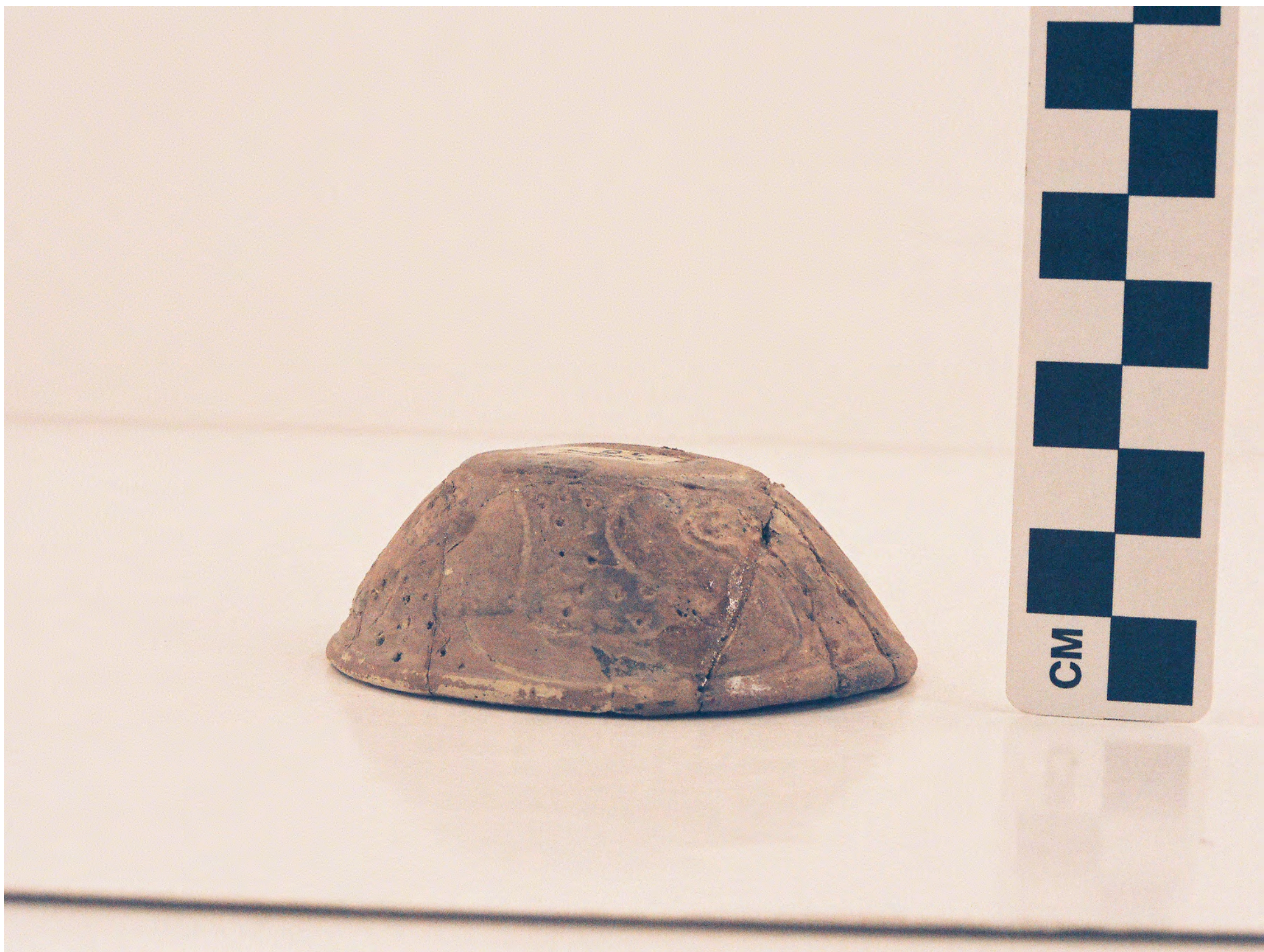

Figure 69 


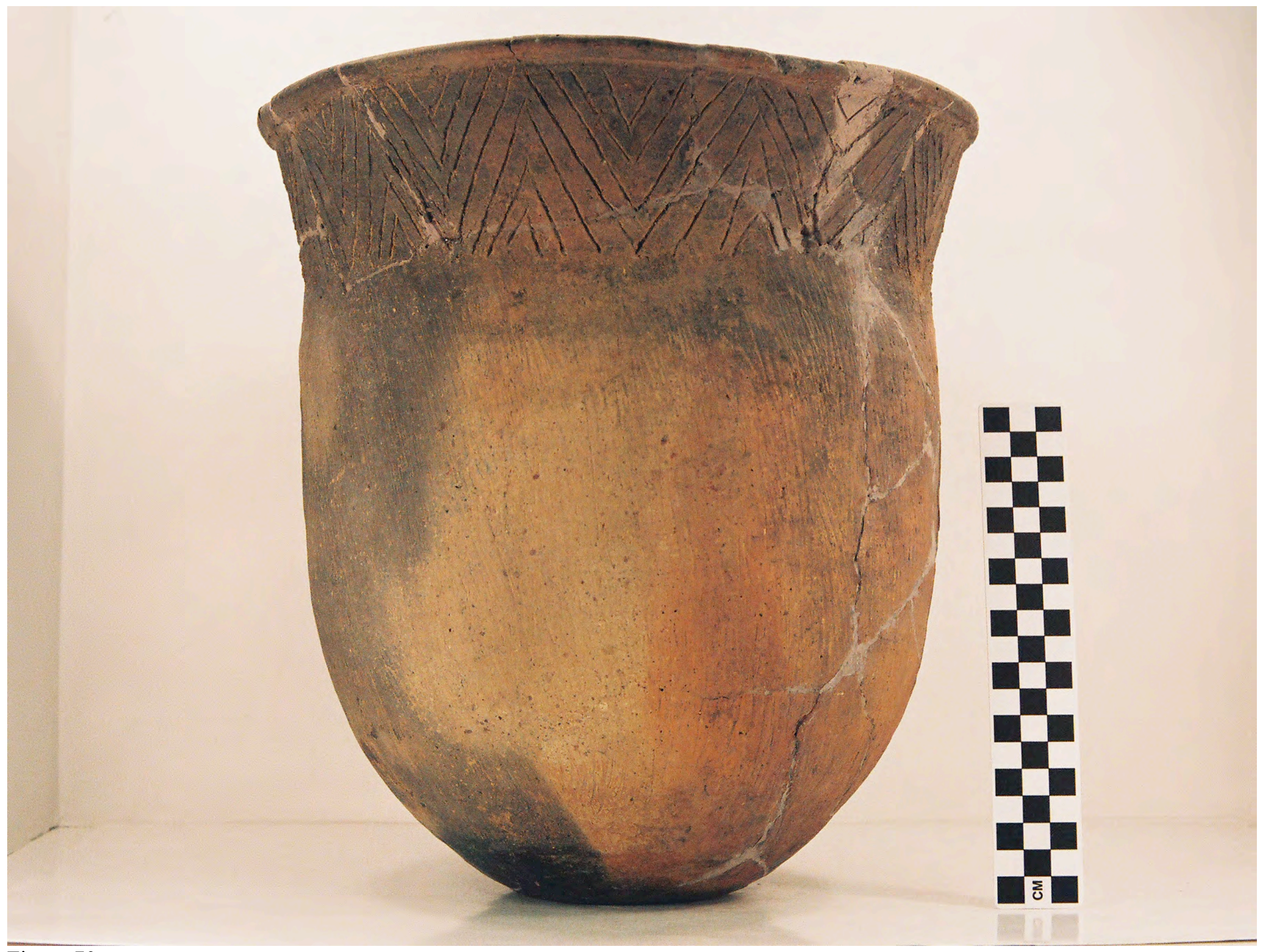

Figure 70 


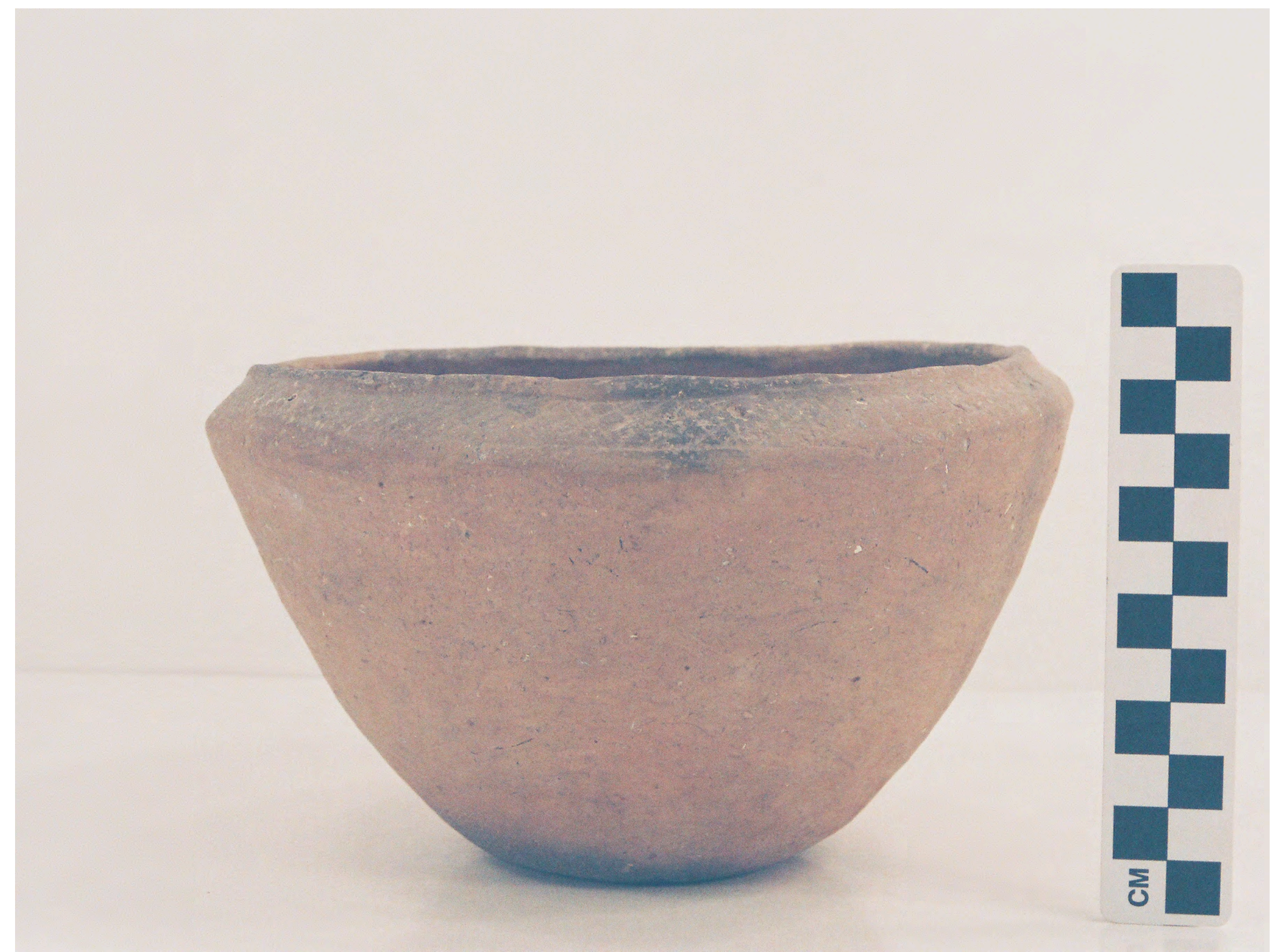

Figure 71 


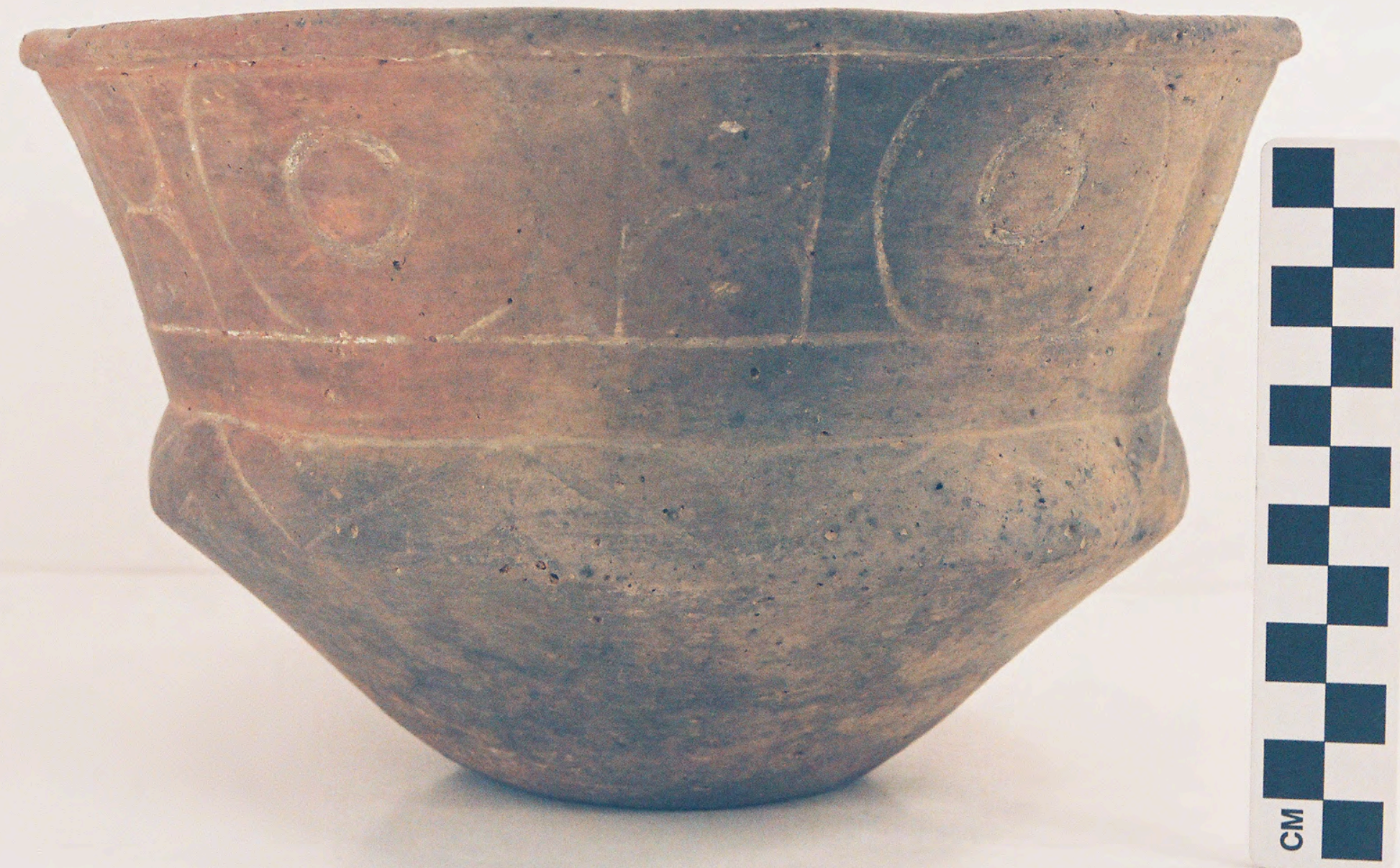

Figure 72 


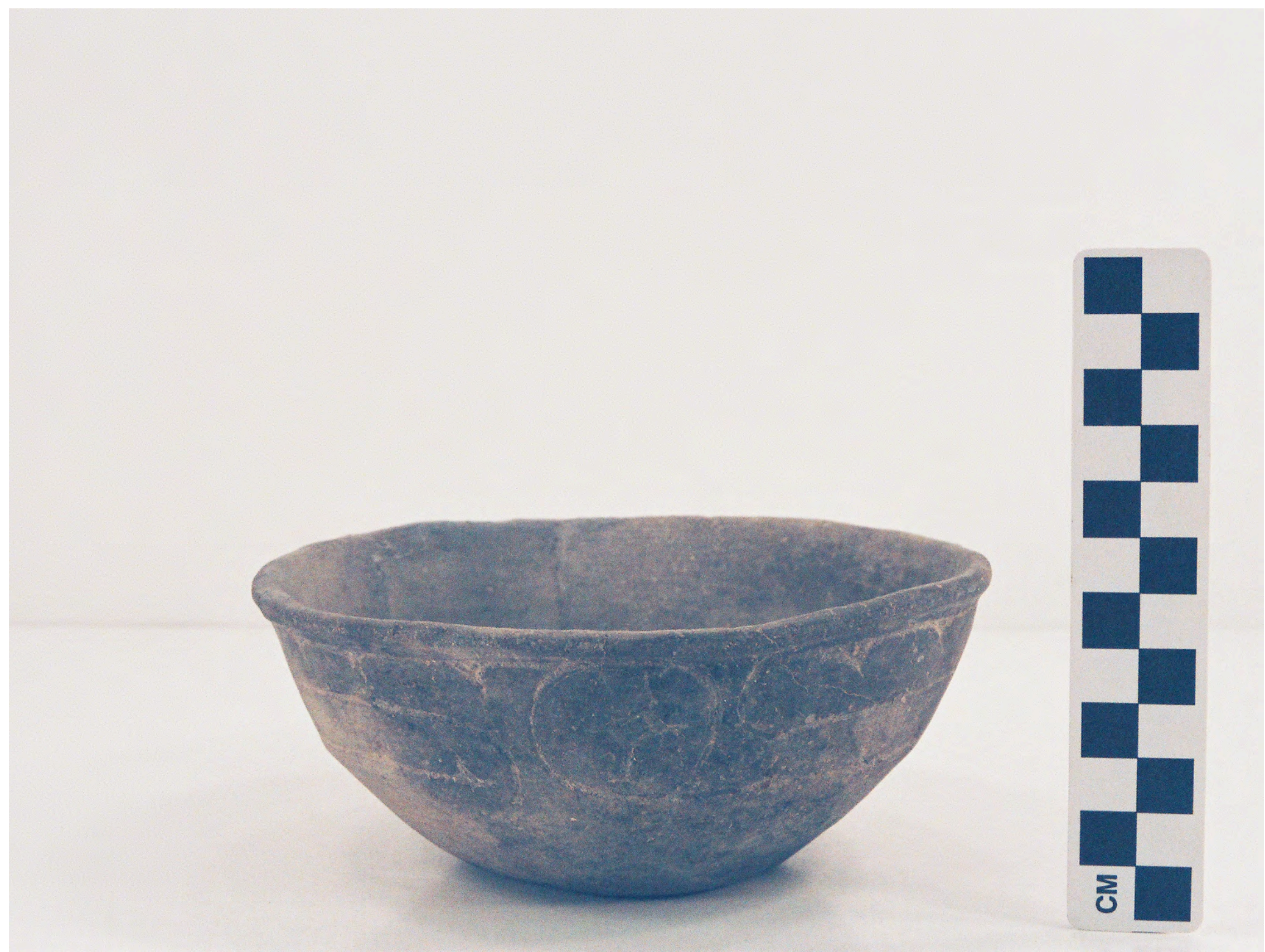

Figure 73 


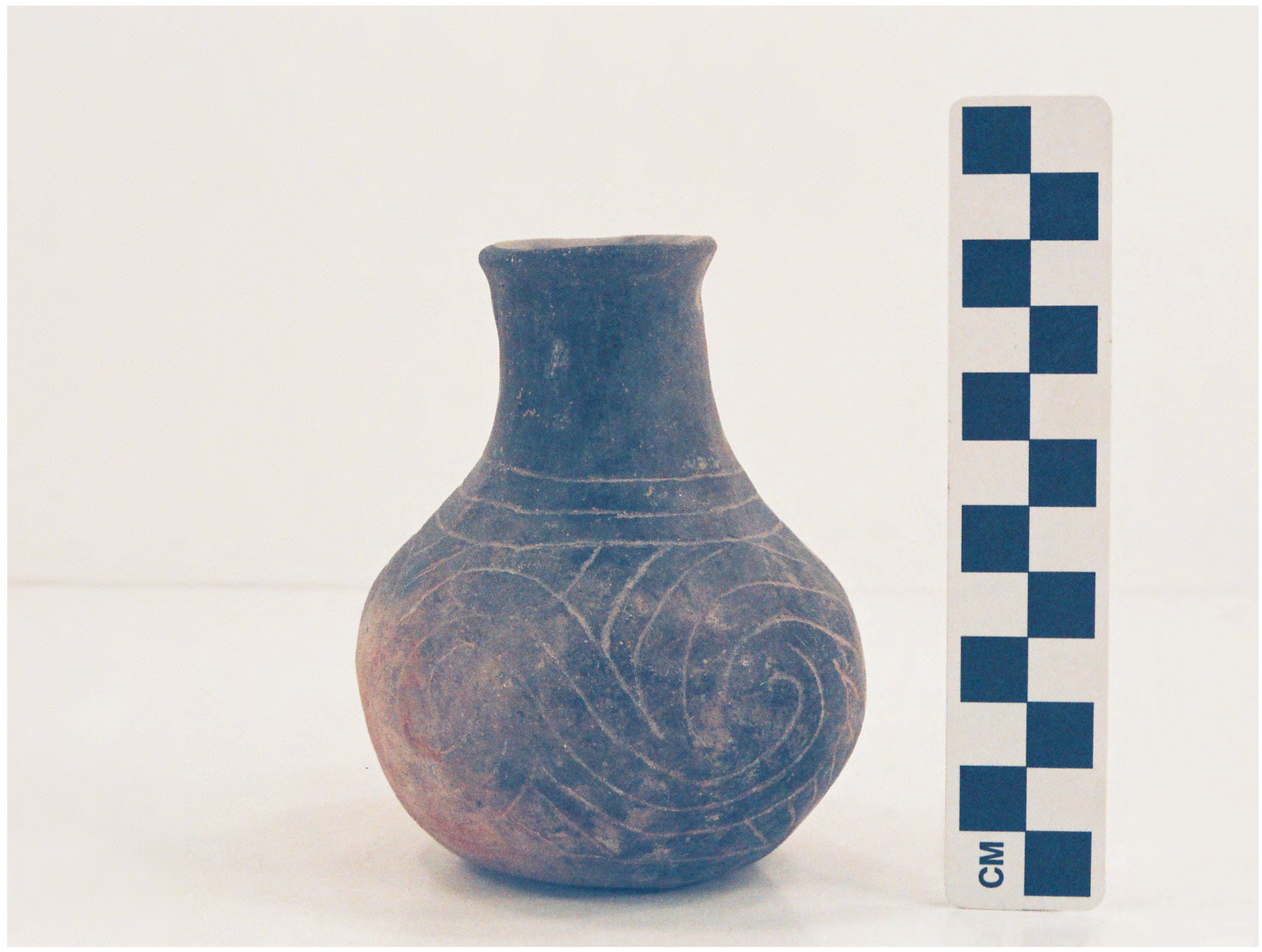

Figure 74 


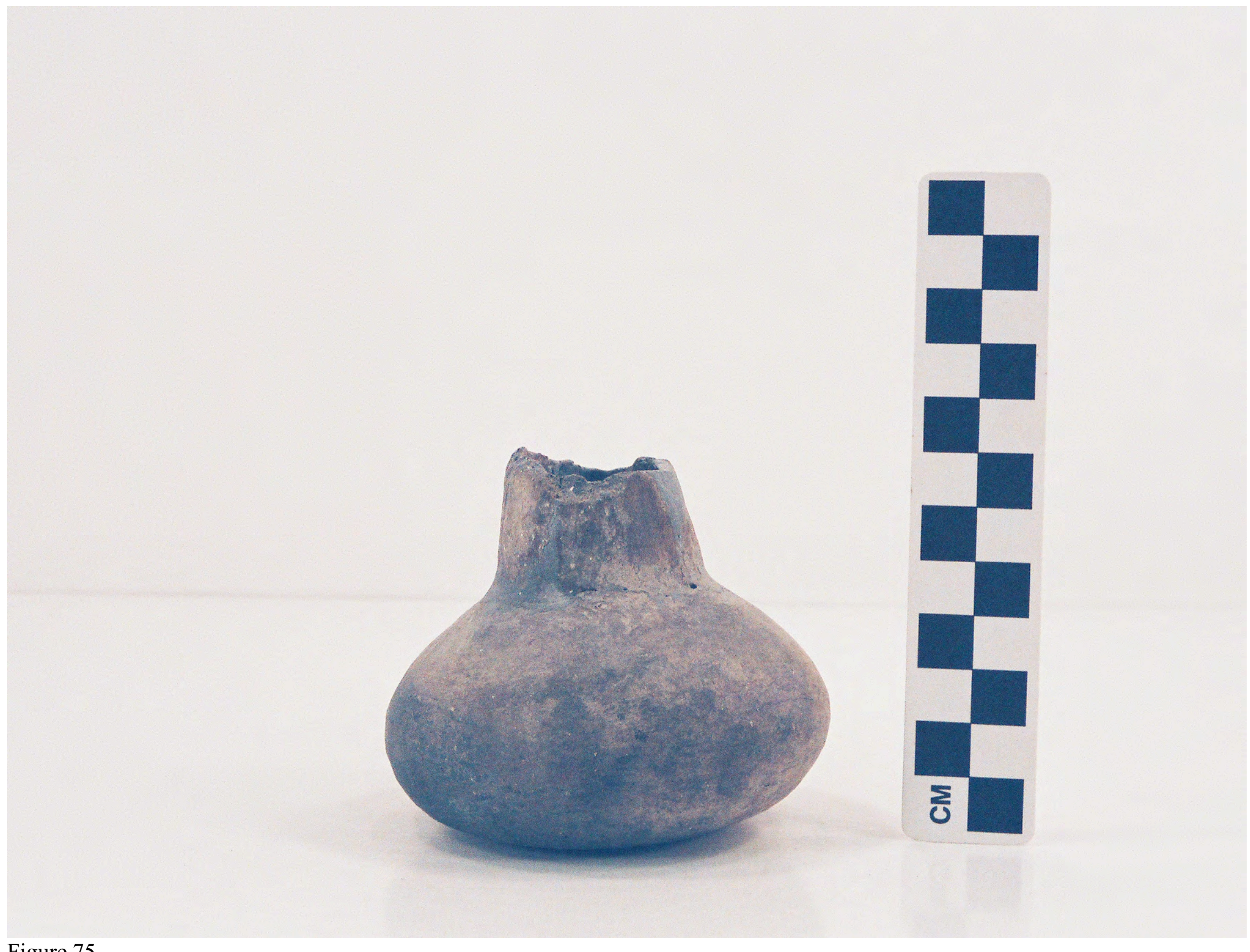

Figure 75 


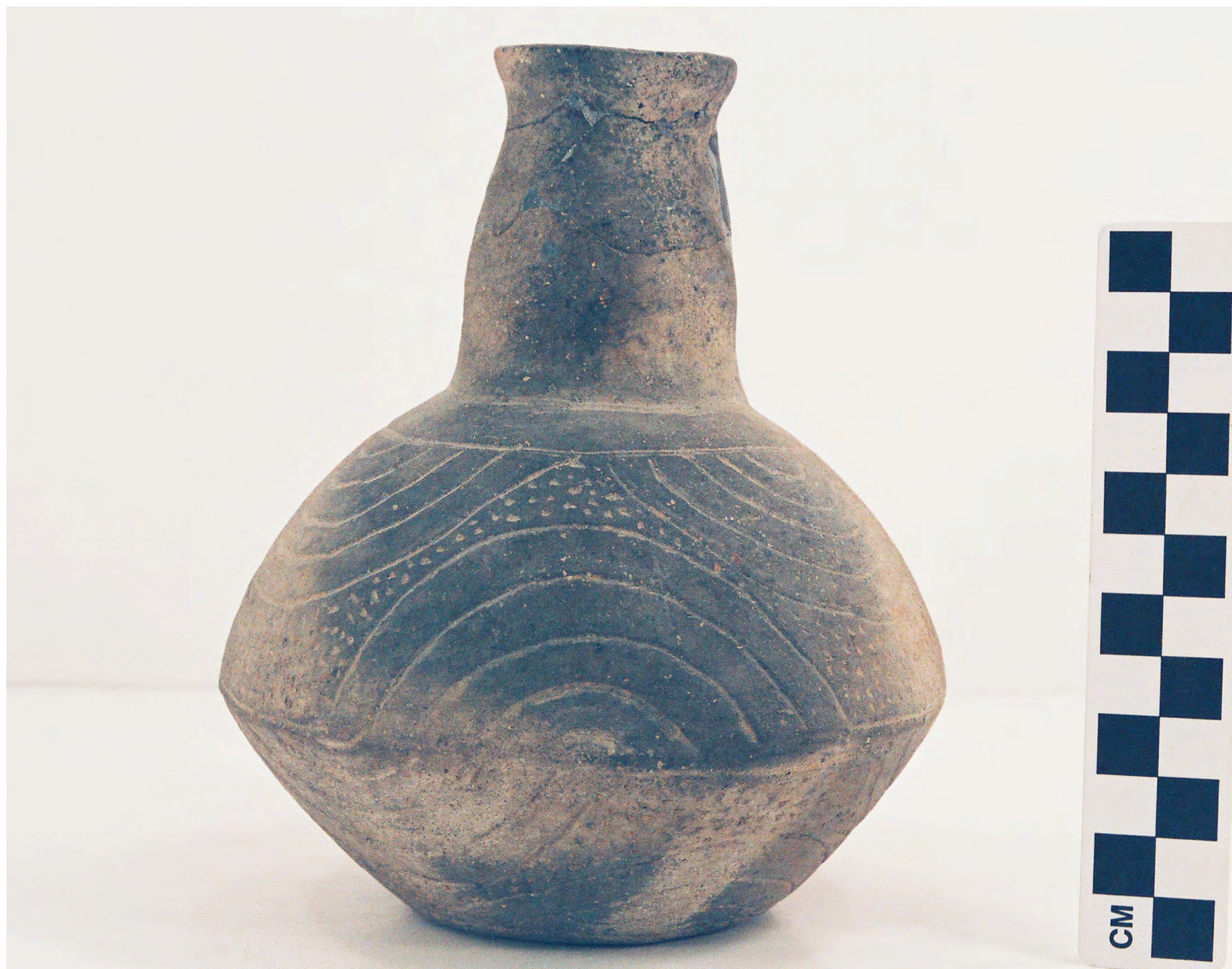

Figure $76 a$ 


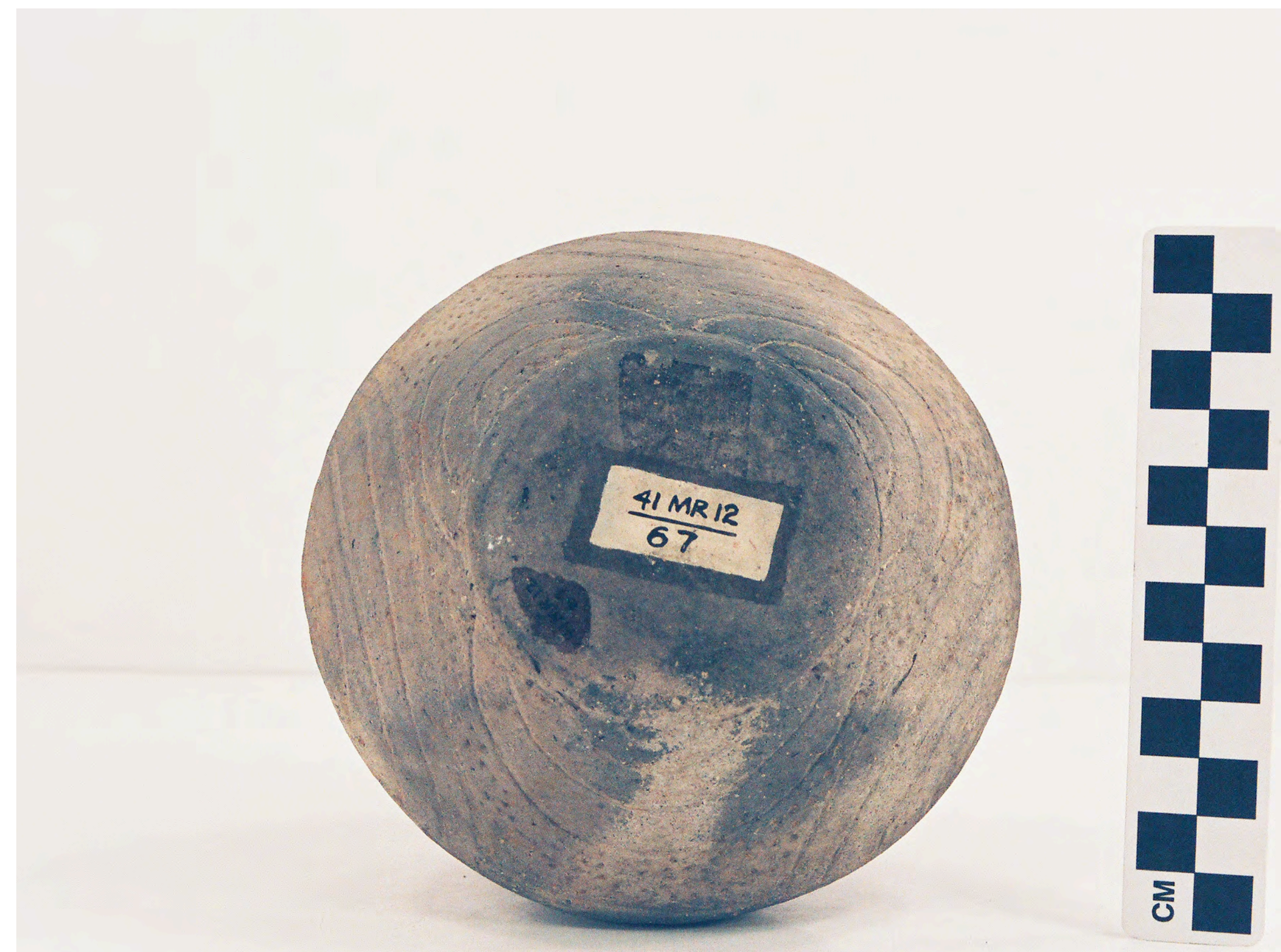

Figure $76 b$ 


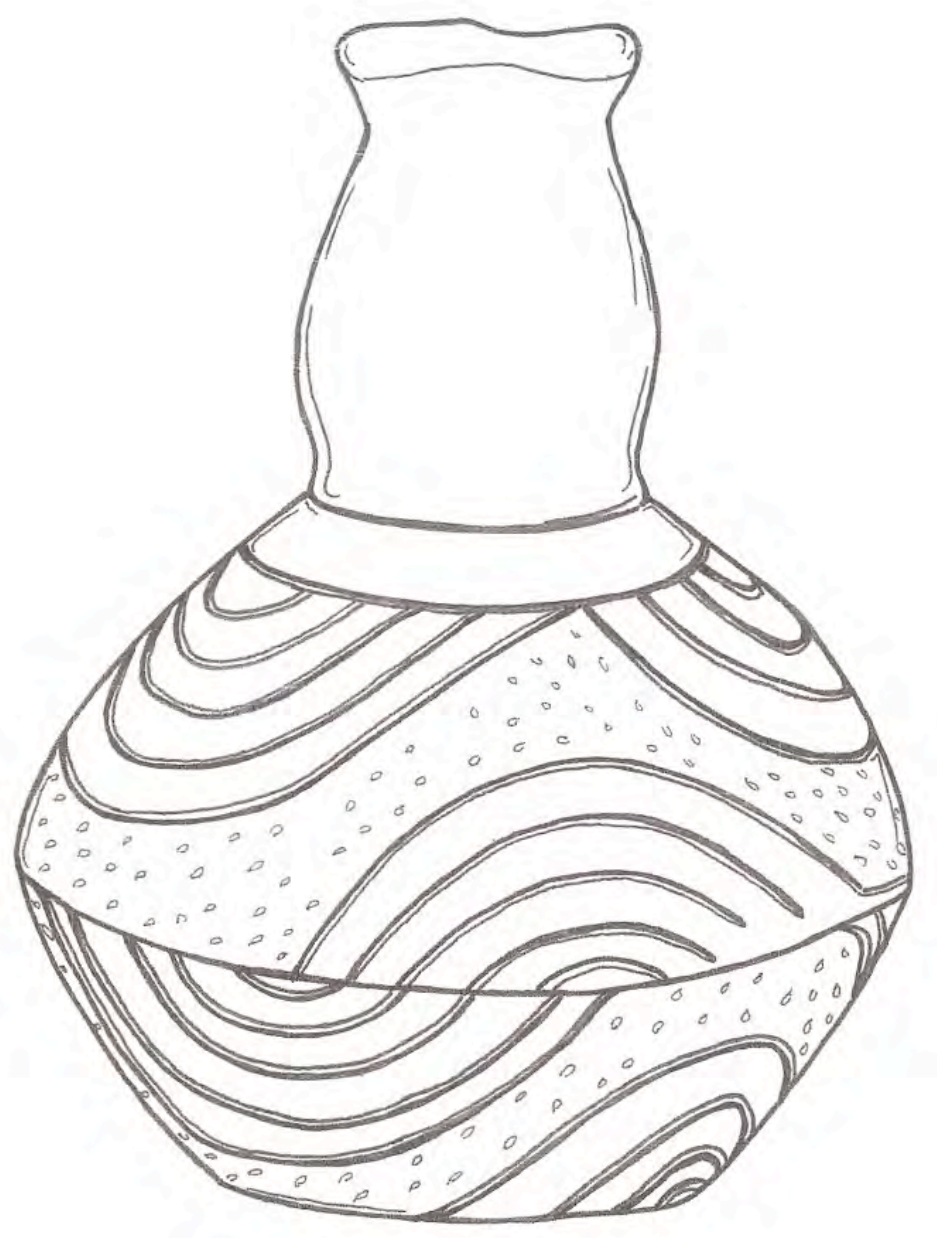

Figure 77. Drawing of the Bailey Engraved bottle (MR12-67) by Bobby Gonzalez.

Figure 77 


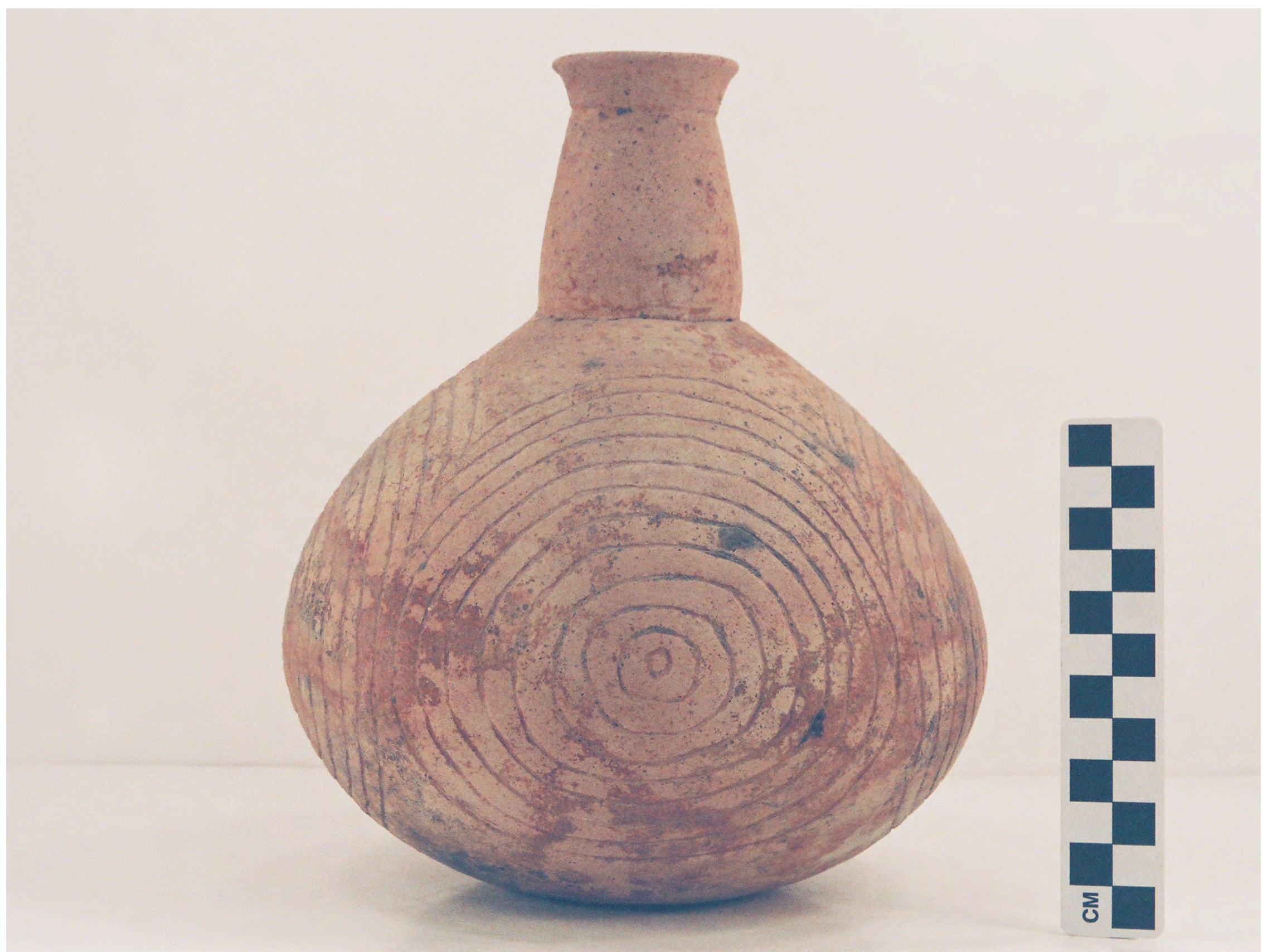

Figure 78 


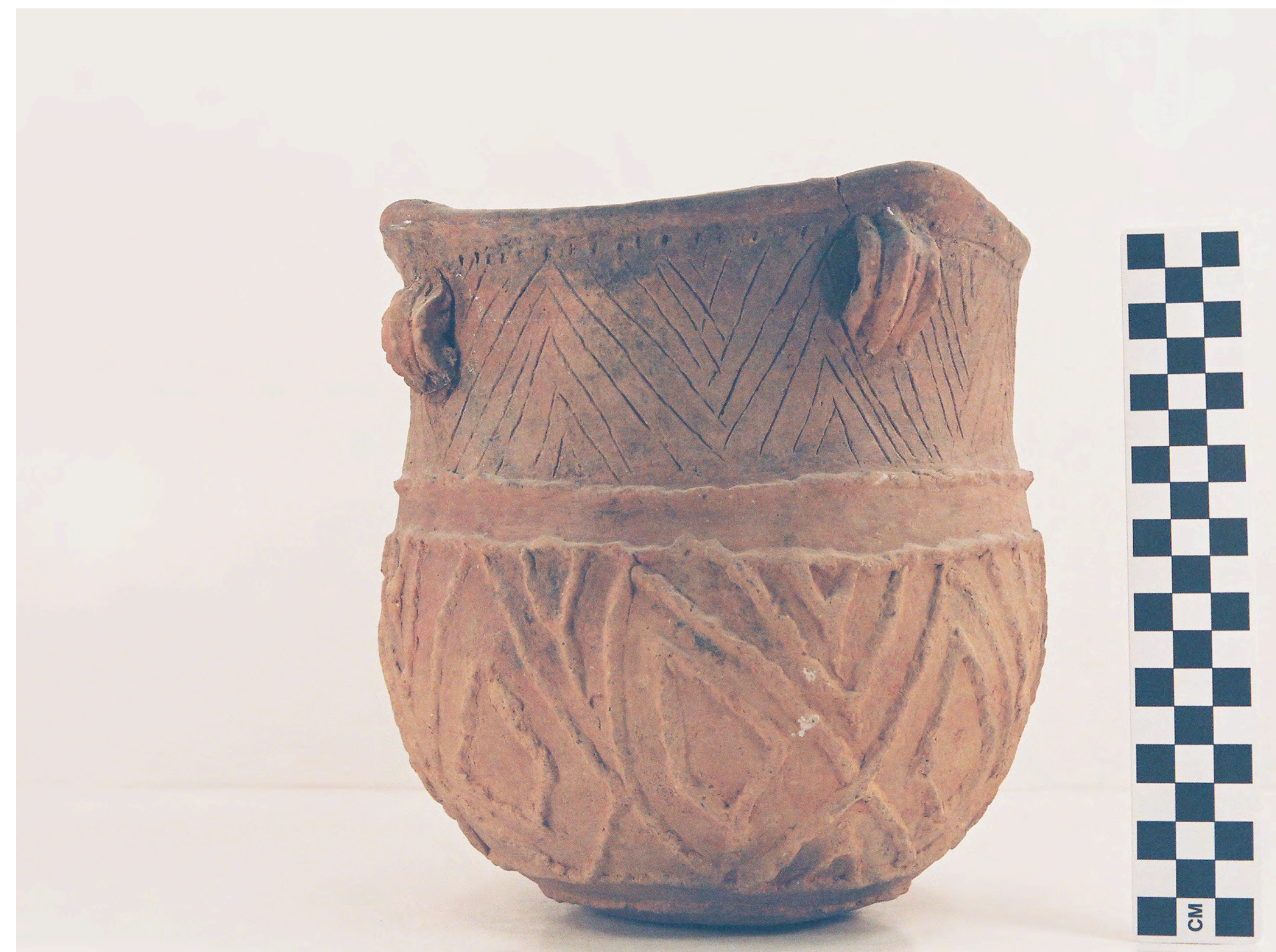

Figure 79 


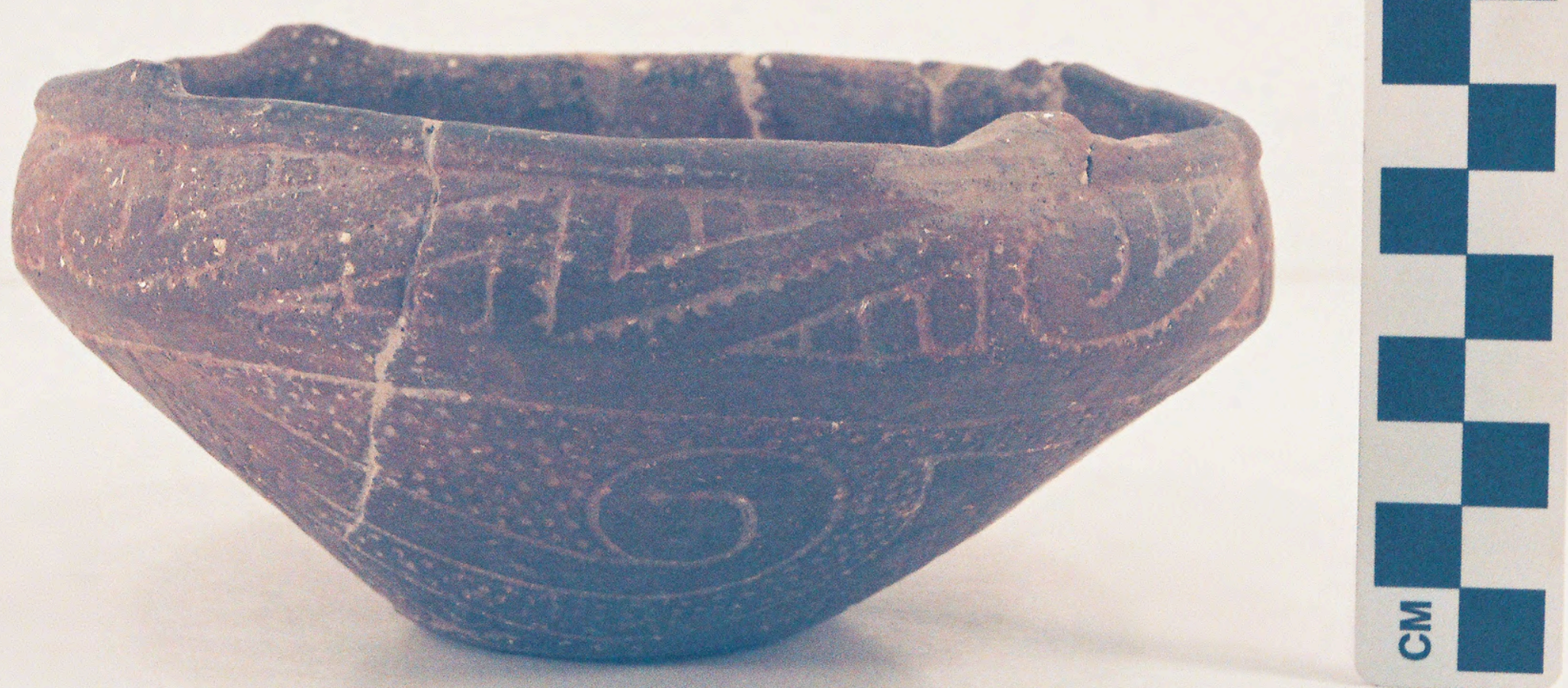

Figure 80a 


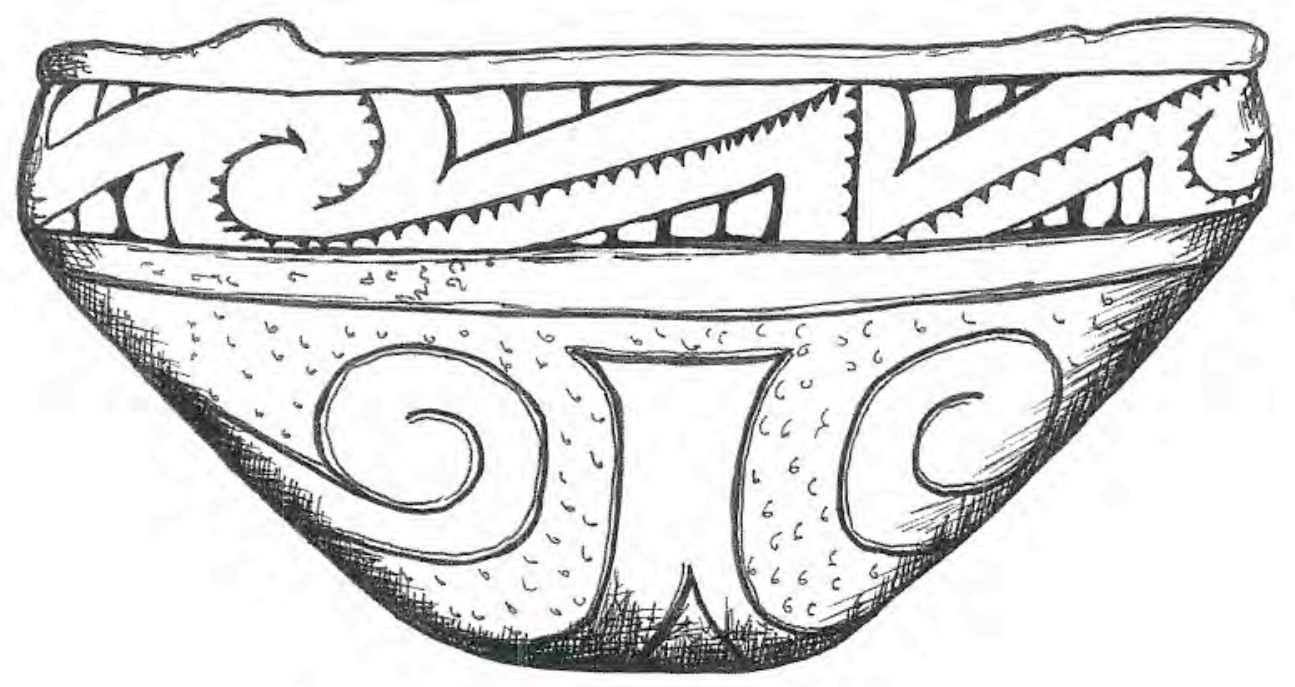

Figure 81. Drawing of Taylor Engraved carinated bowl from Burial I at the Ben McKinney site.

Figure $80 \mathrm{~b}$ 


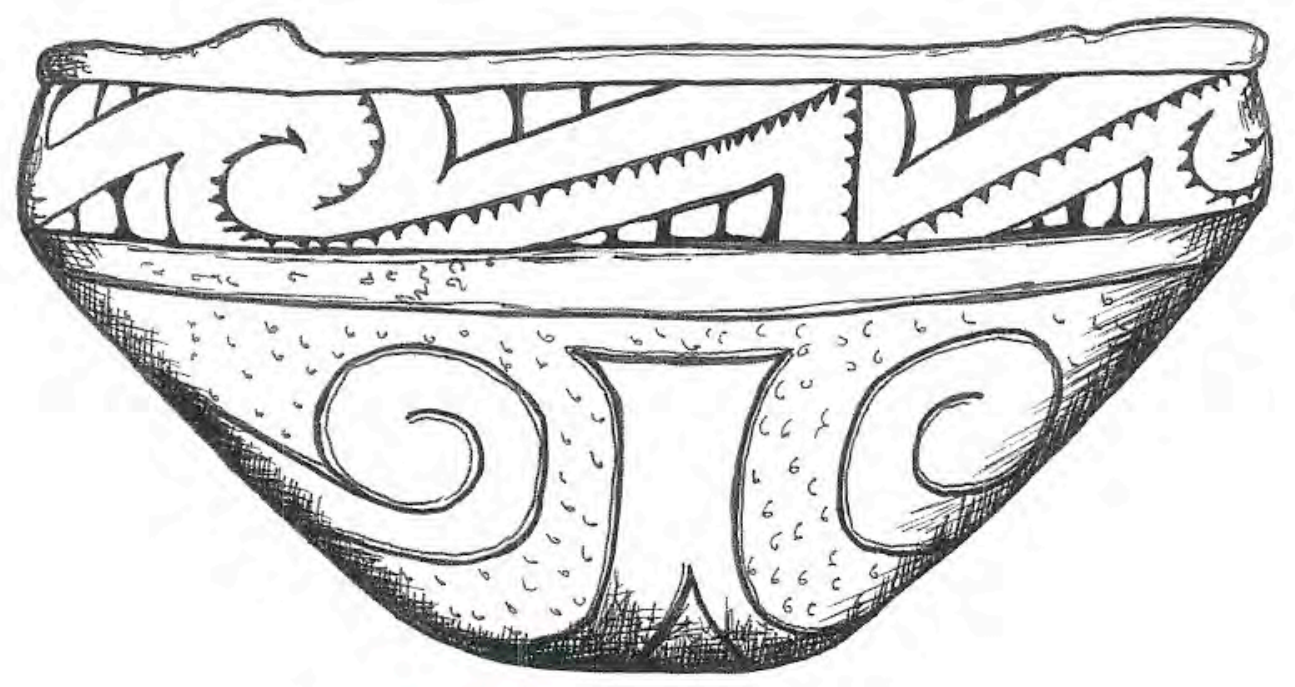

Figure 81. Drawing of Taylor Engraved carinated bowl from Burial I at the Ben McKinney site.

Figure 81 


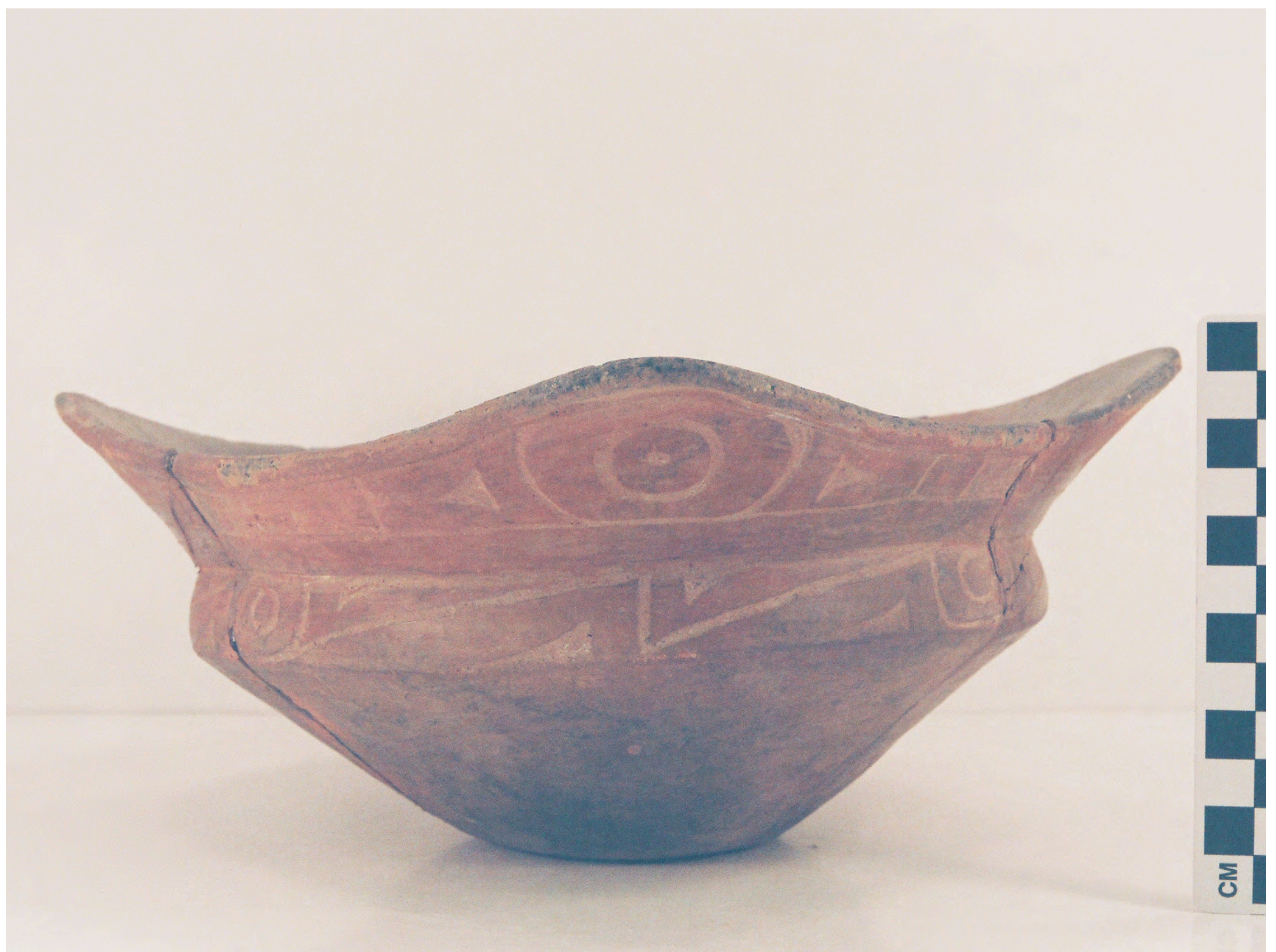

Figure $82 \mathrm{a}$ 


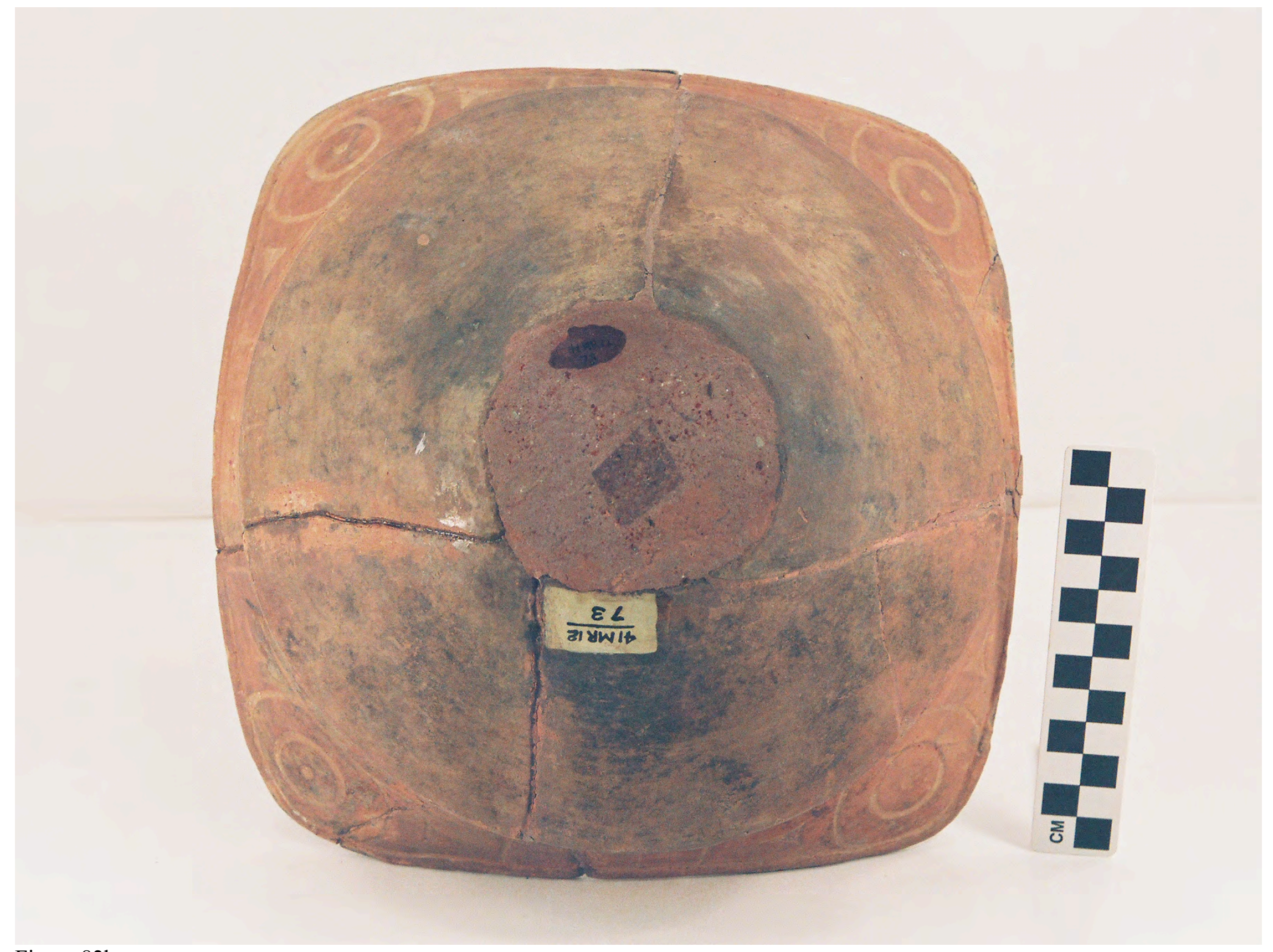

Figure $82 b$ 


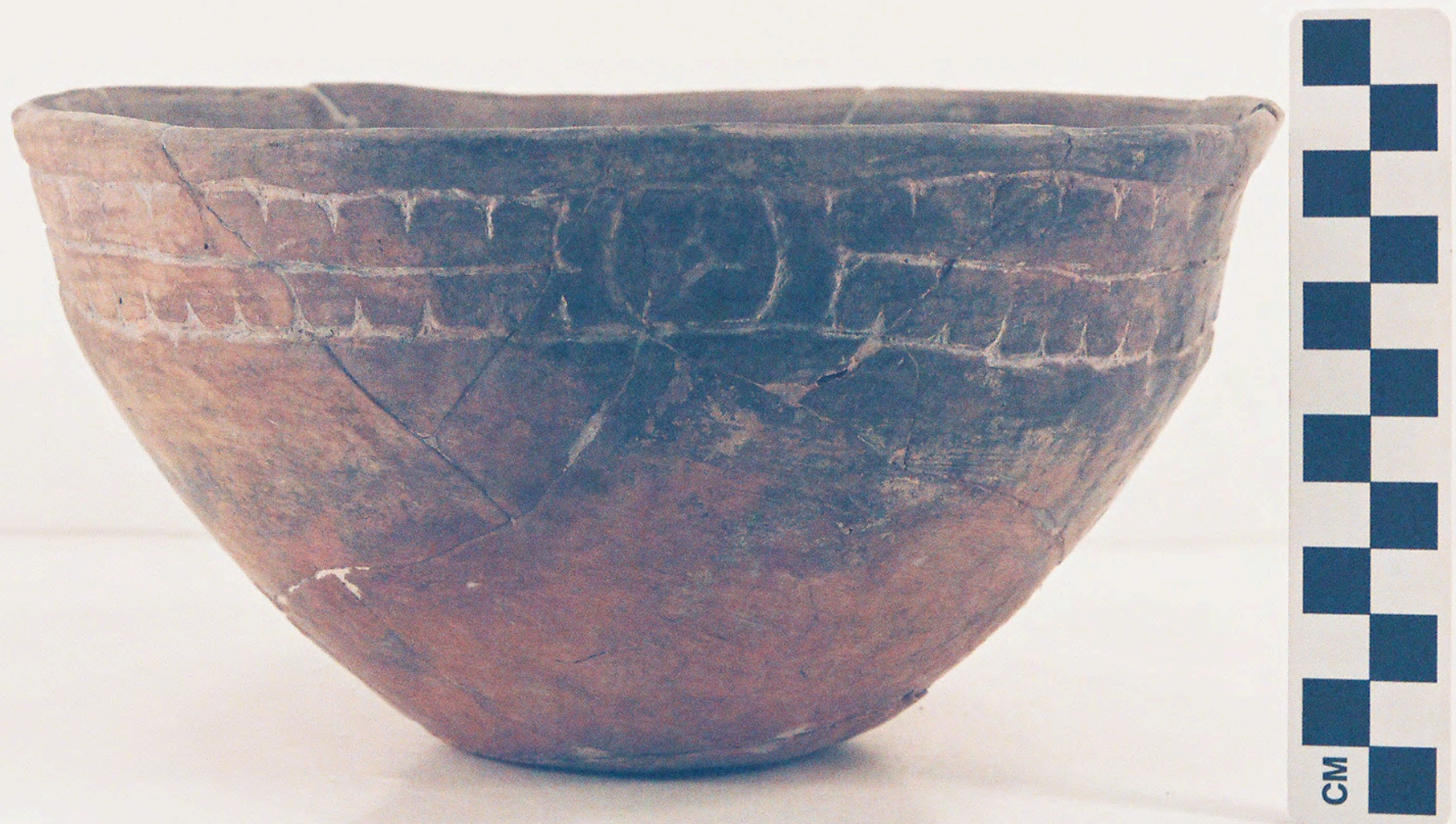

Figure 83 


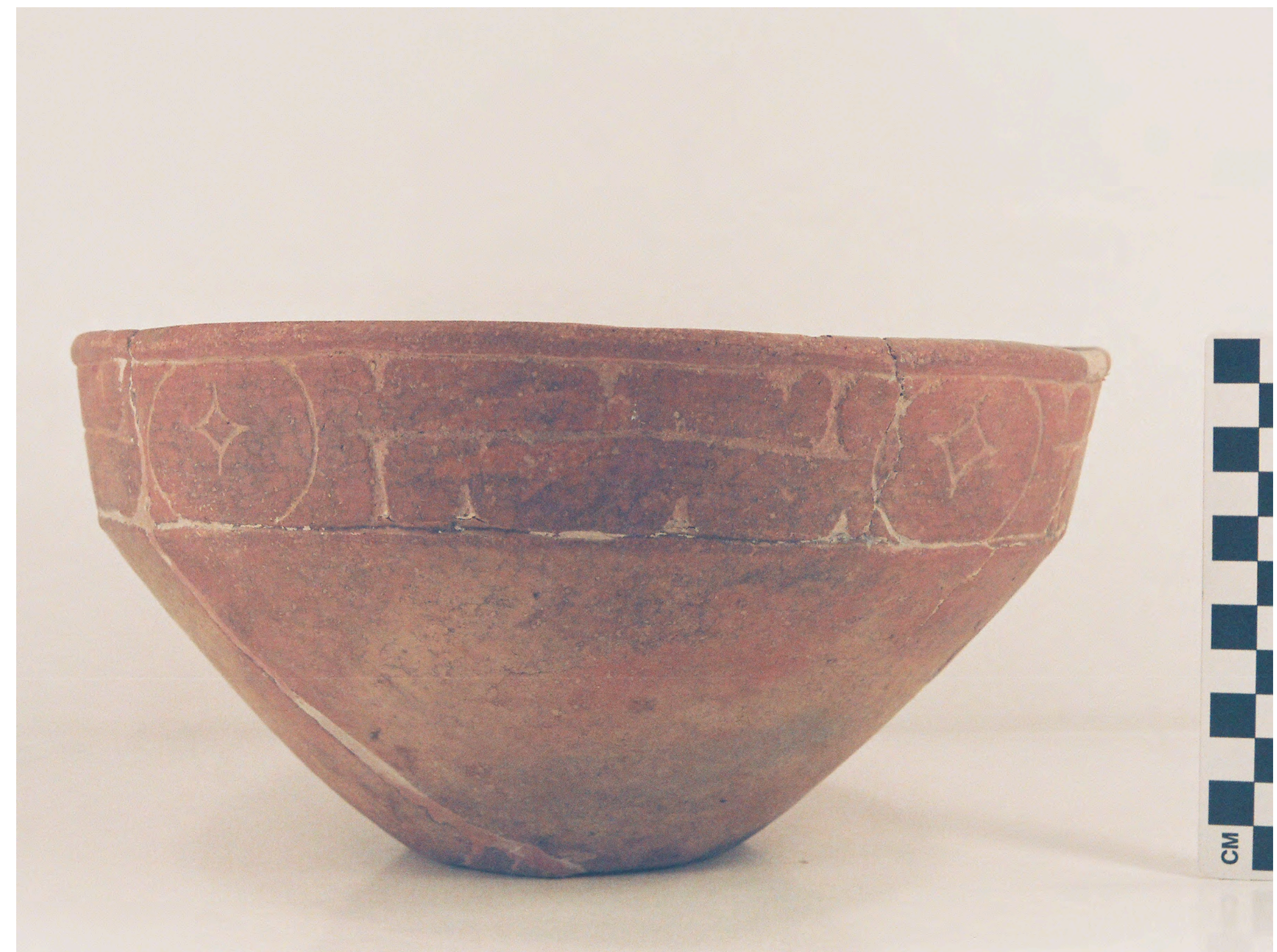

Figure 85 


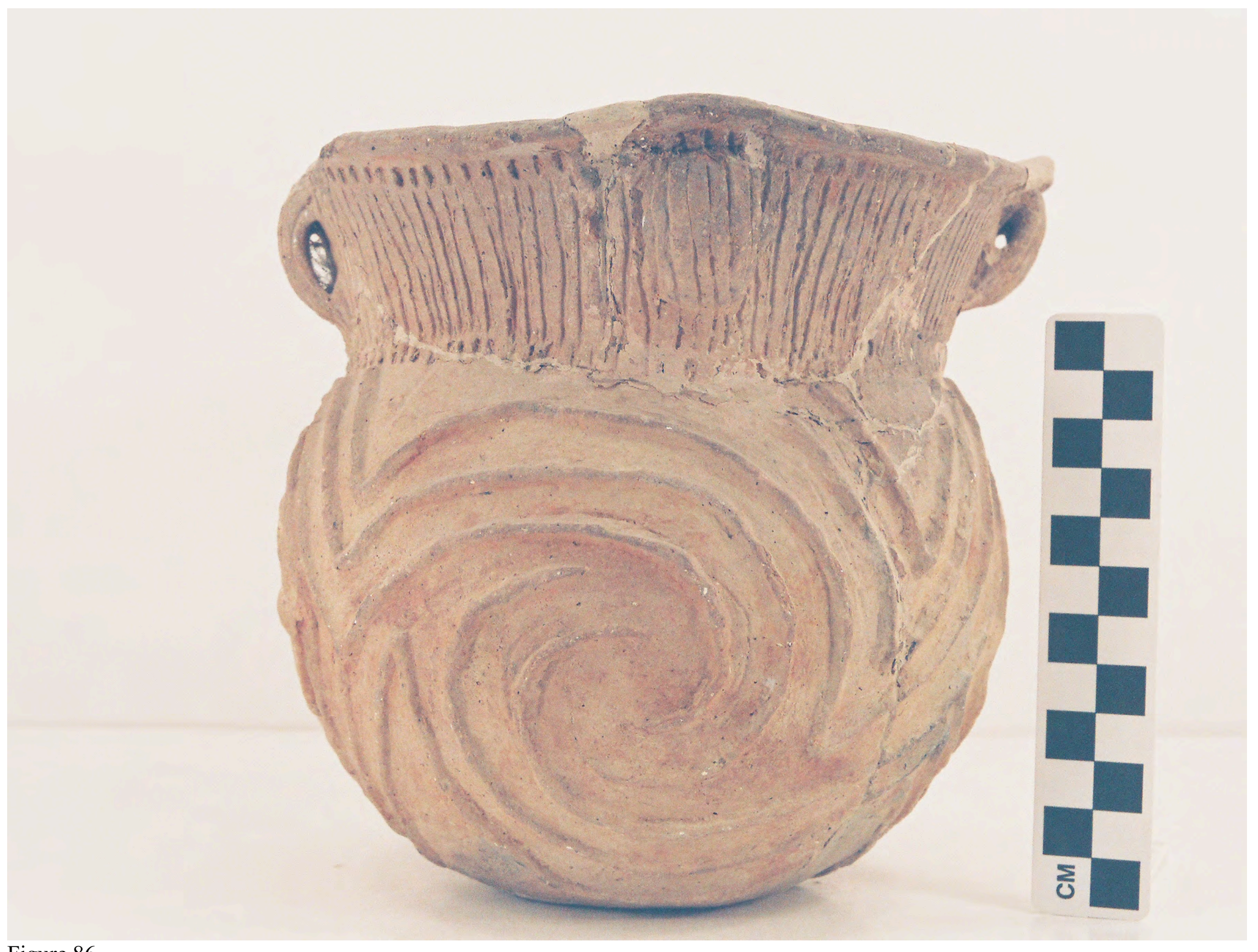

Figure 86 


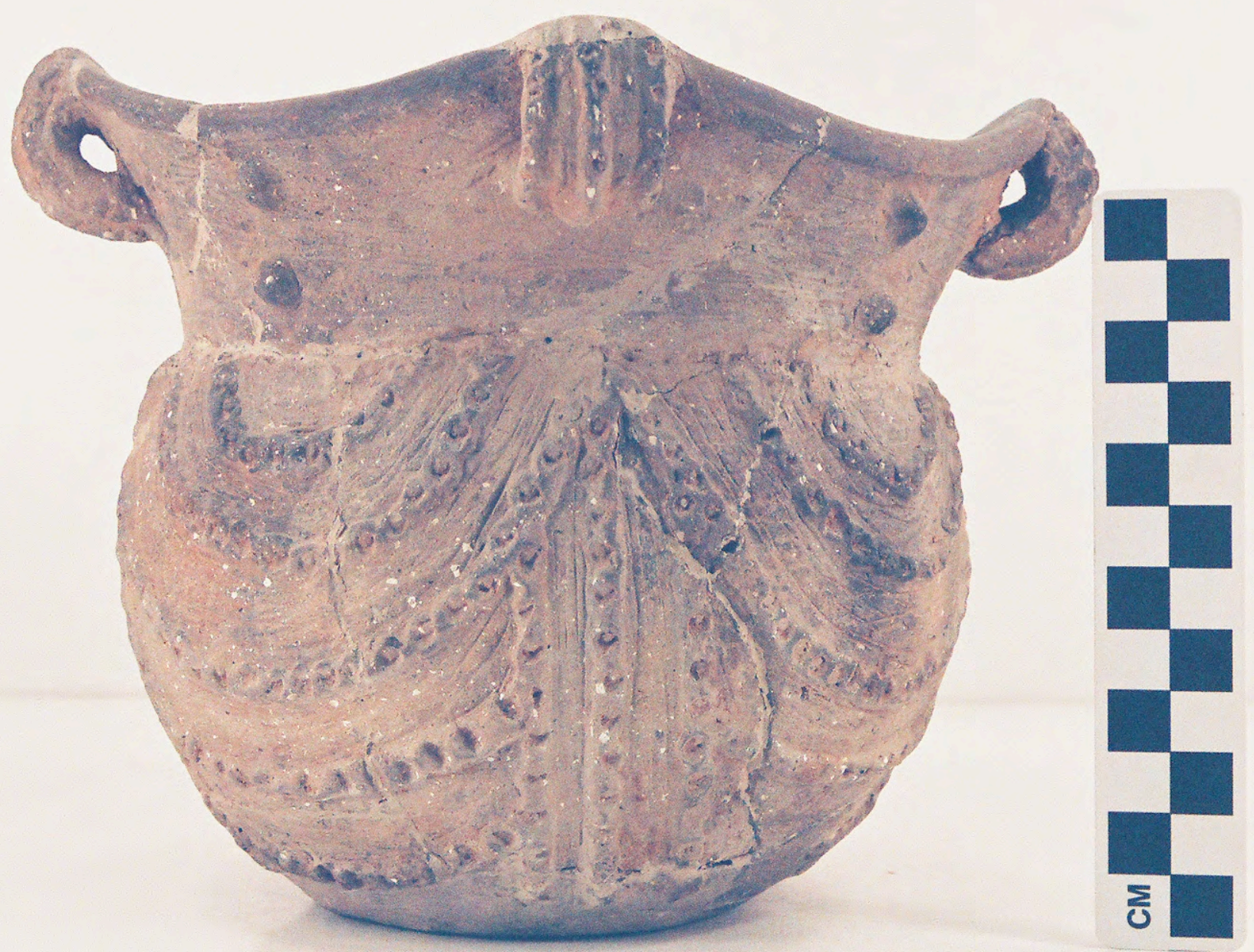

Figure 87 

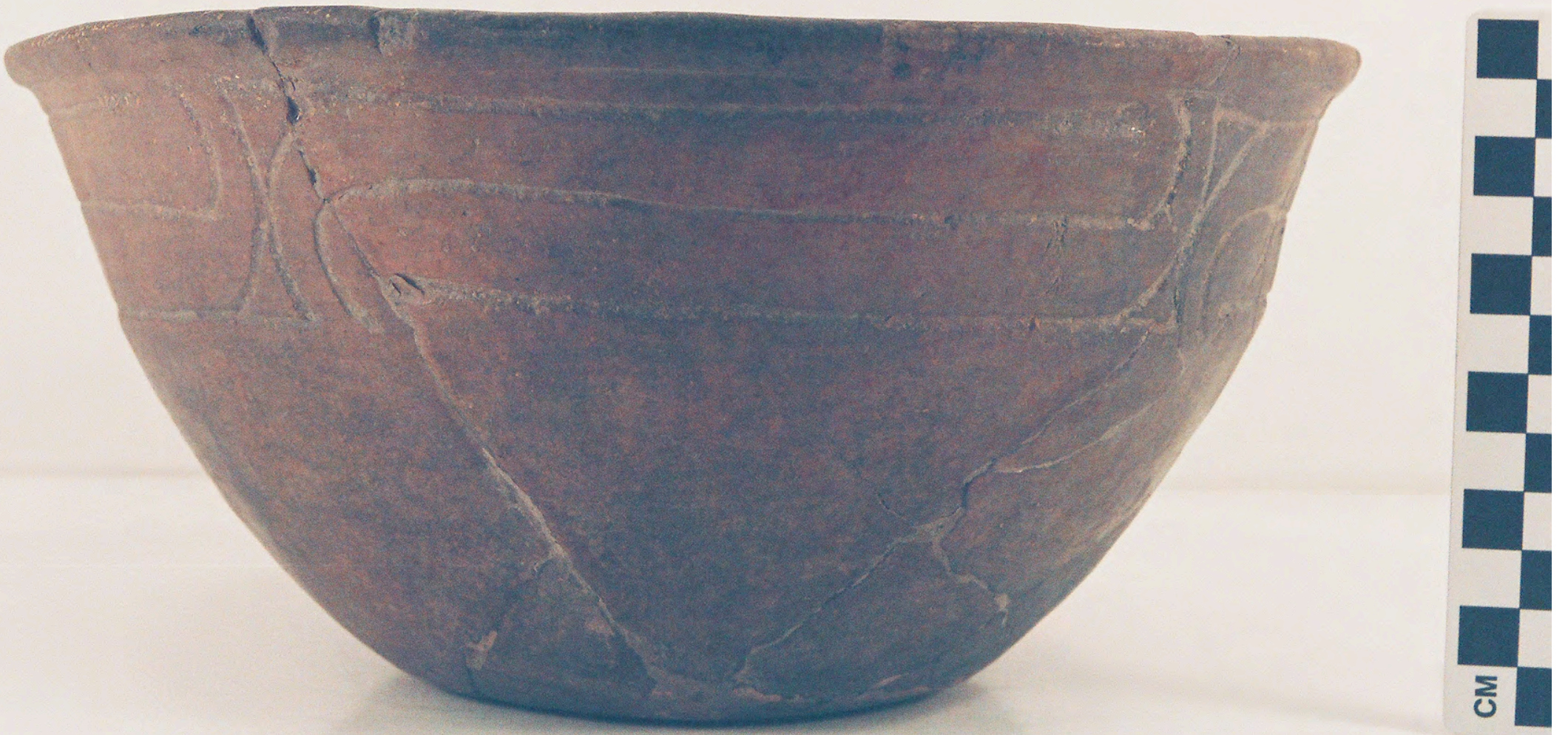

Figure 88 


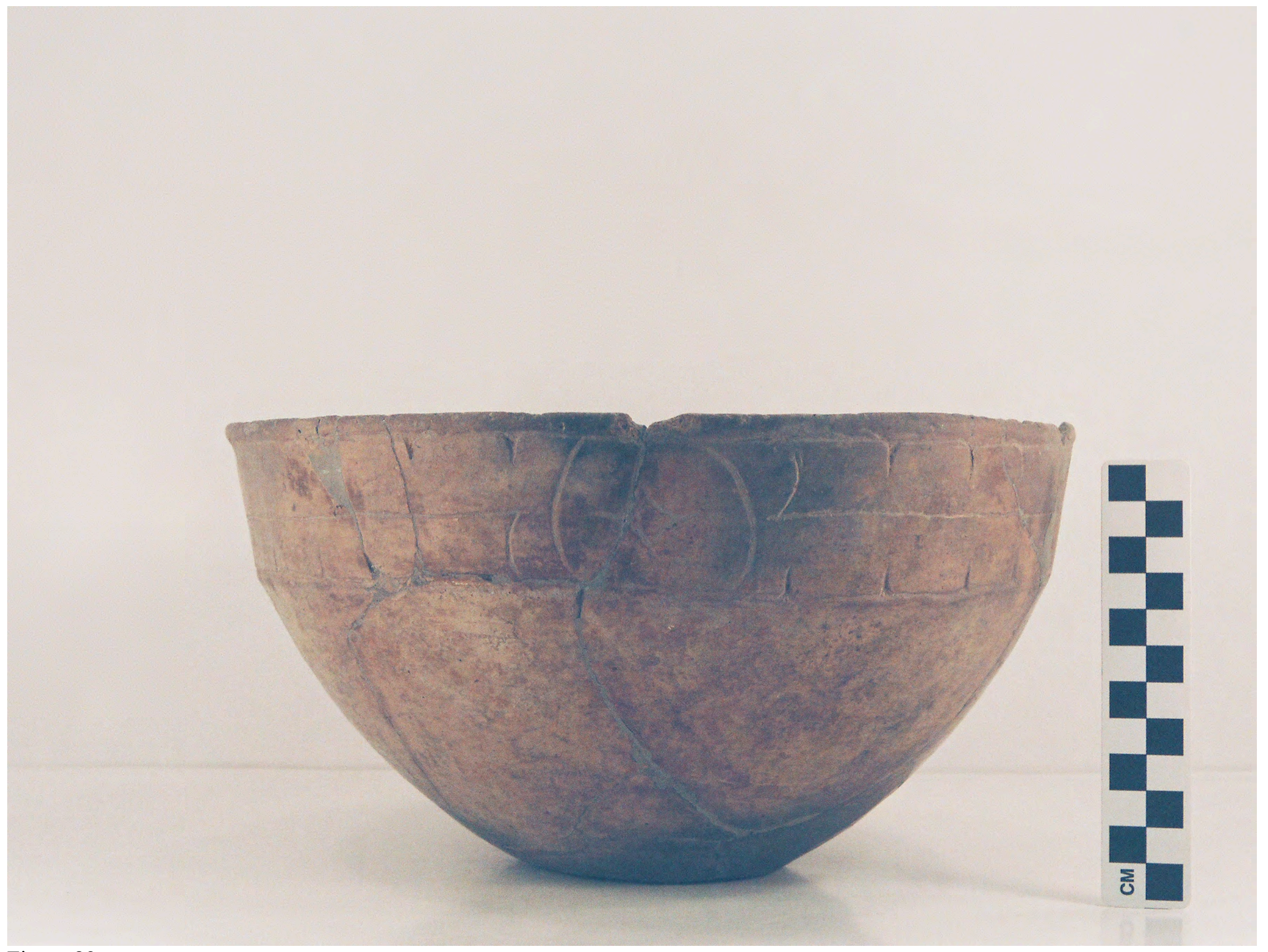

Figure 89 


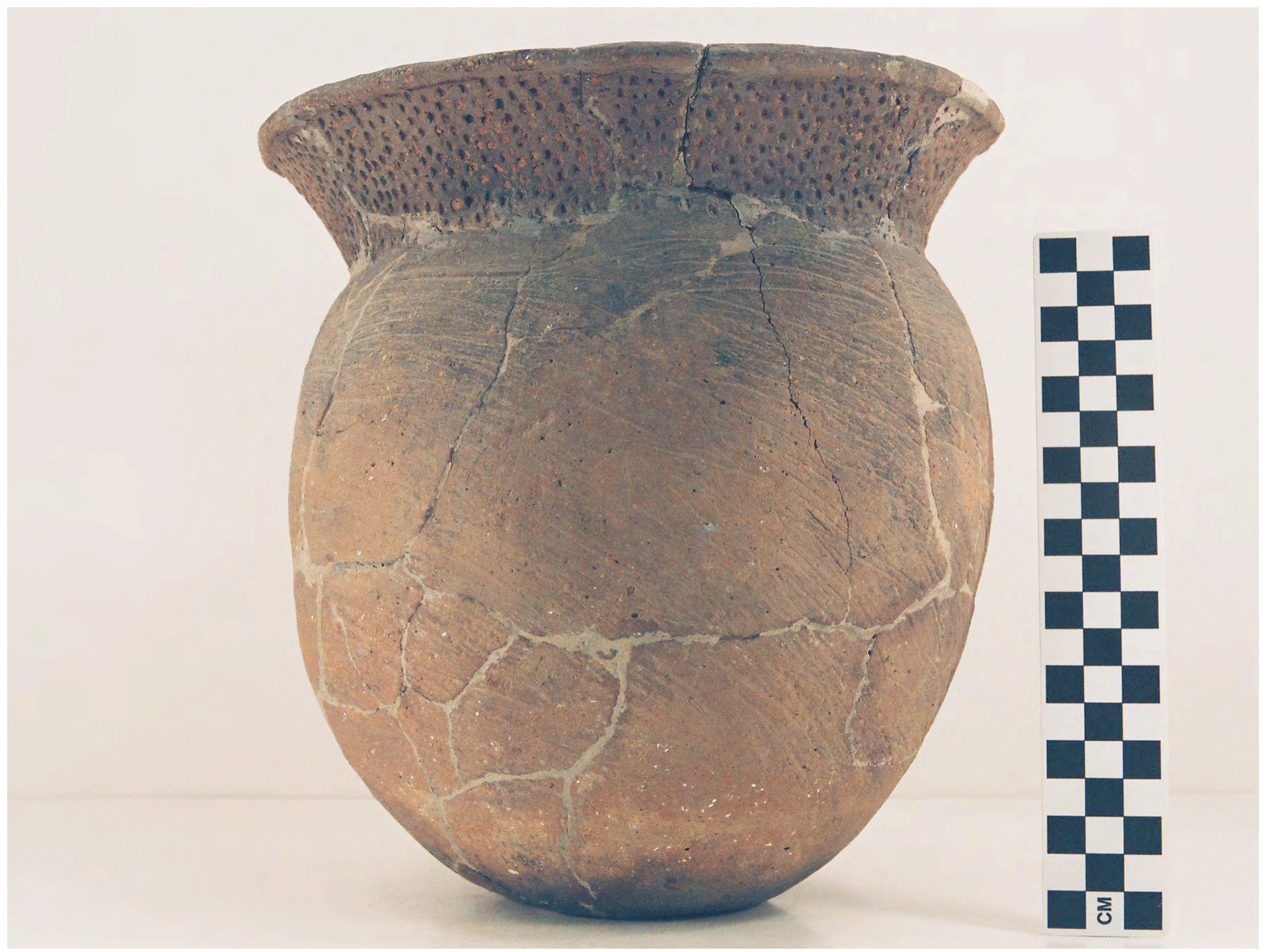

Figure 90 


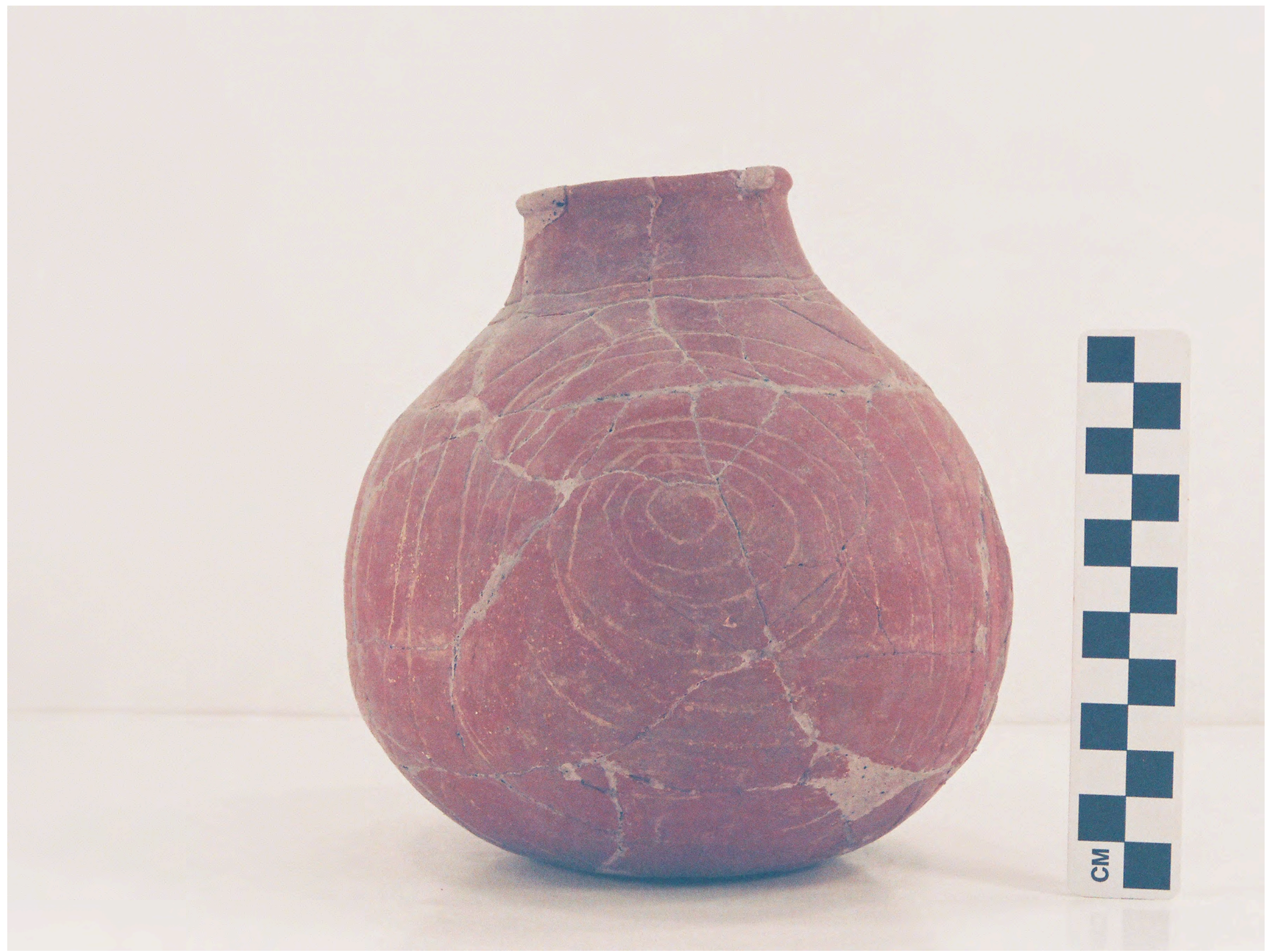

Figure 91 


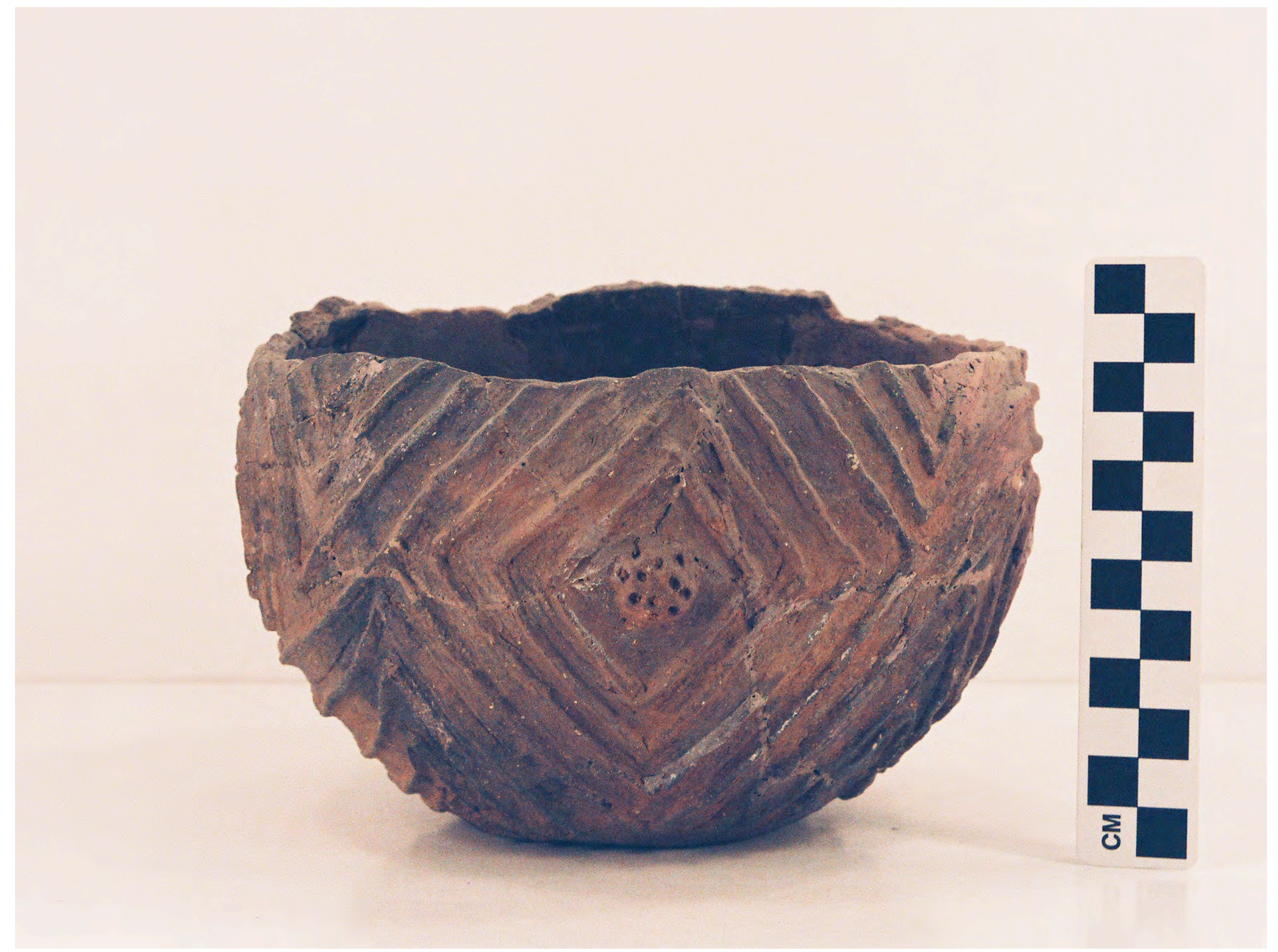

Figure 92 


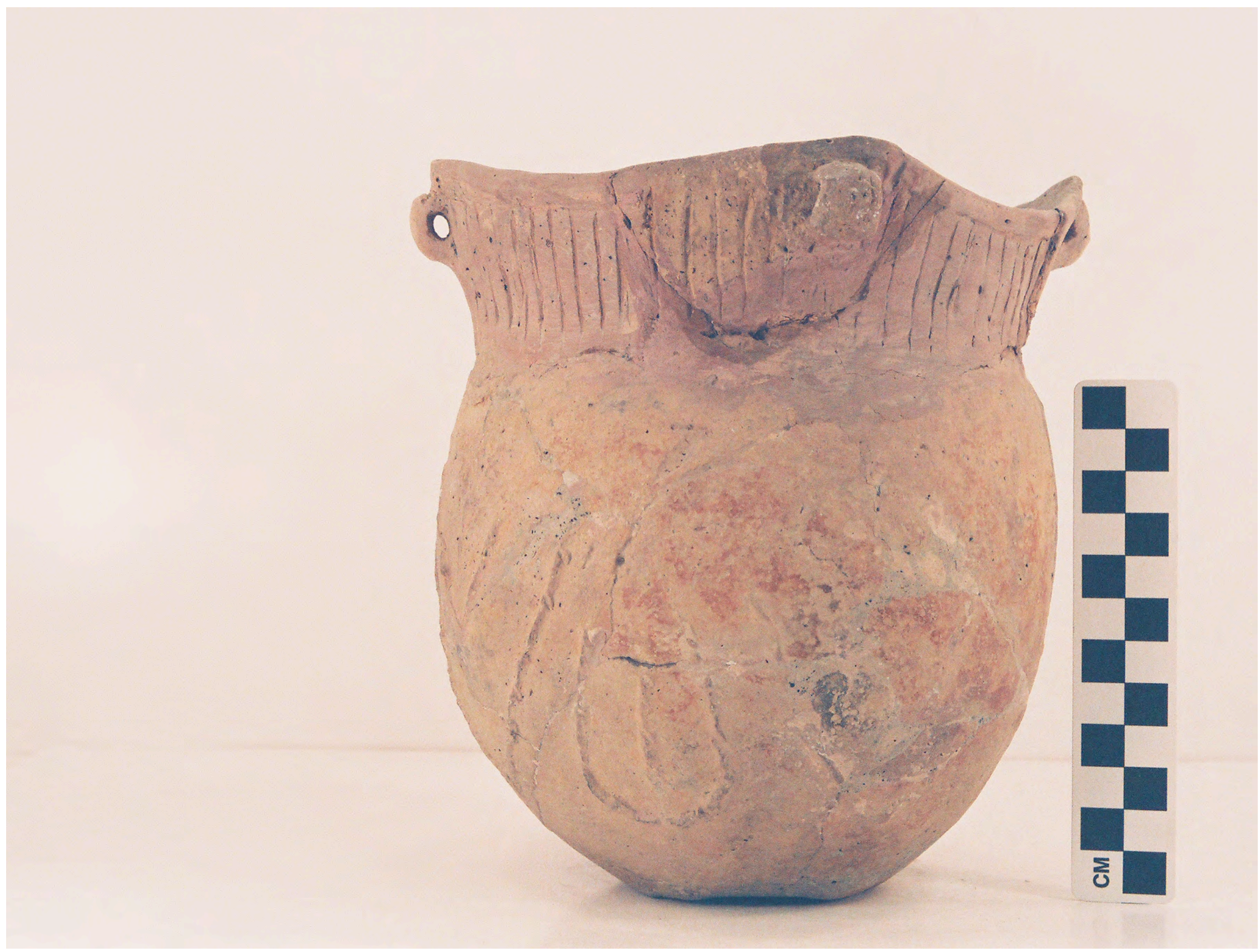

Figure 93 


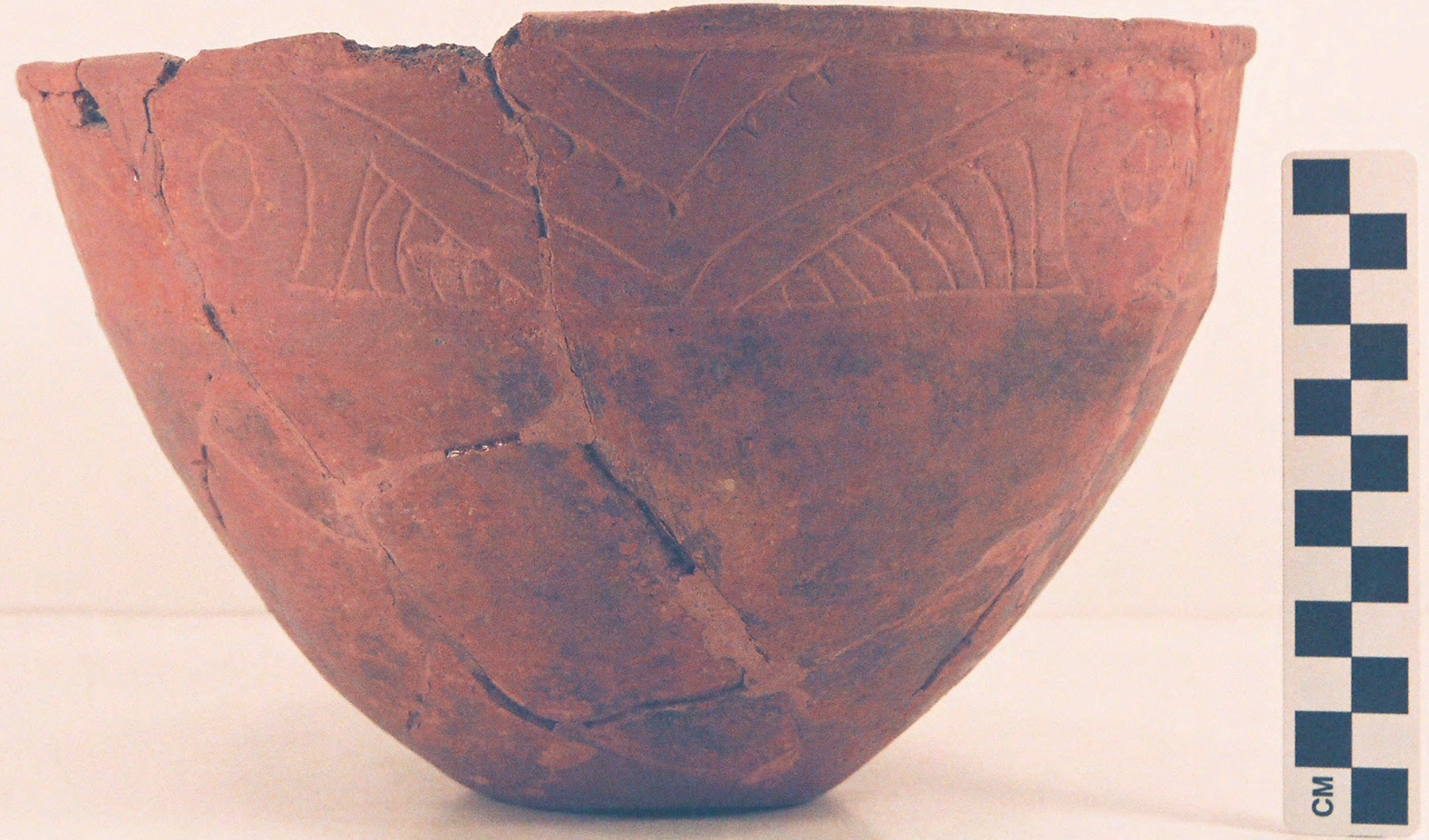

Figure 94a 


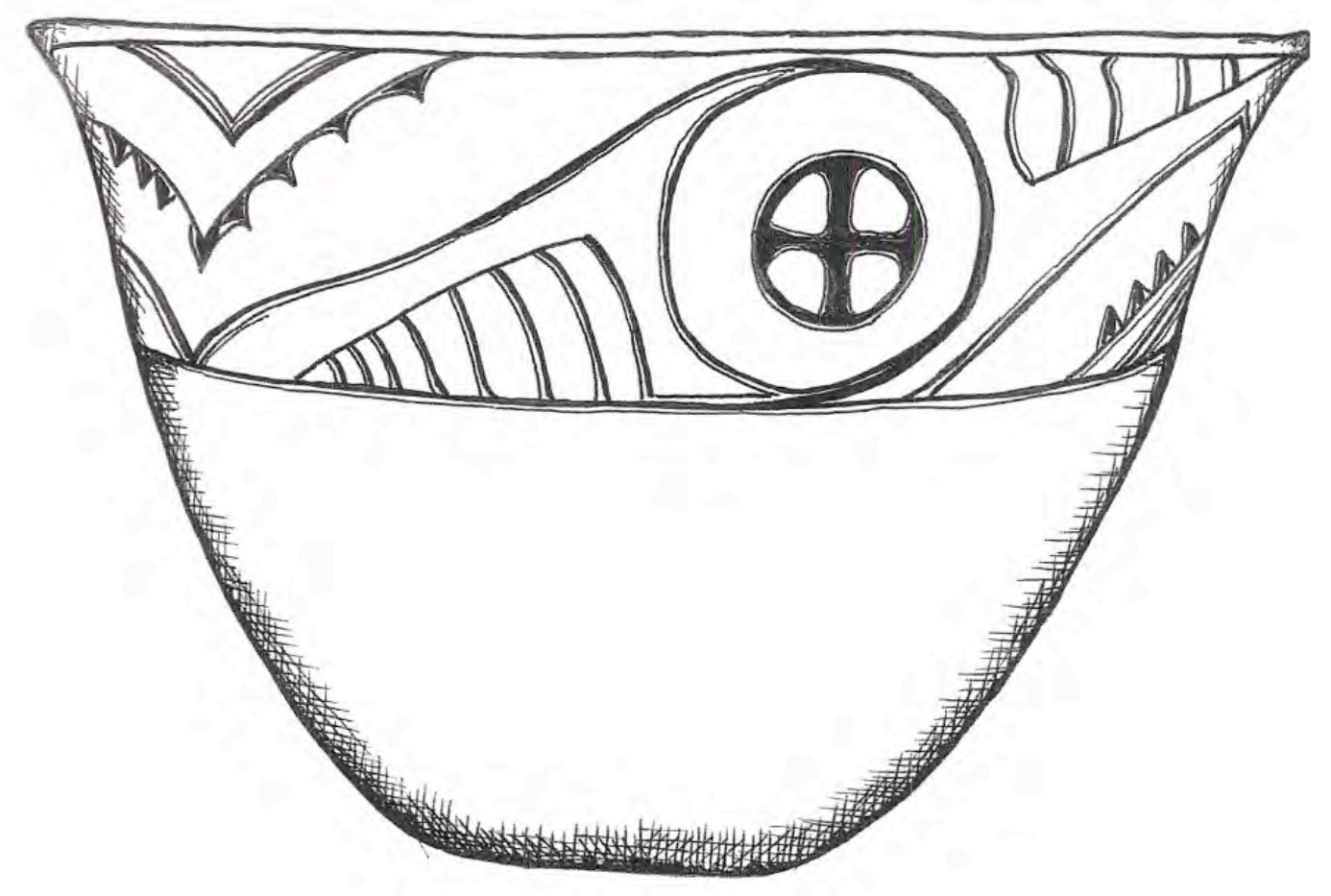

Figure 94. Ripley Engraved carinated bowl (MR12-105) from Burial I at the Ben McKinney site: $b$, drawing by Bobby Gonzalez

Figure $94 b$ 


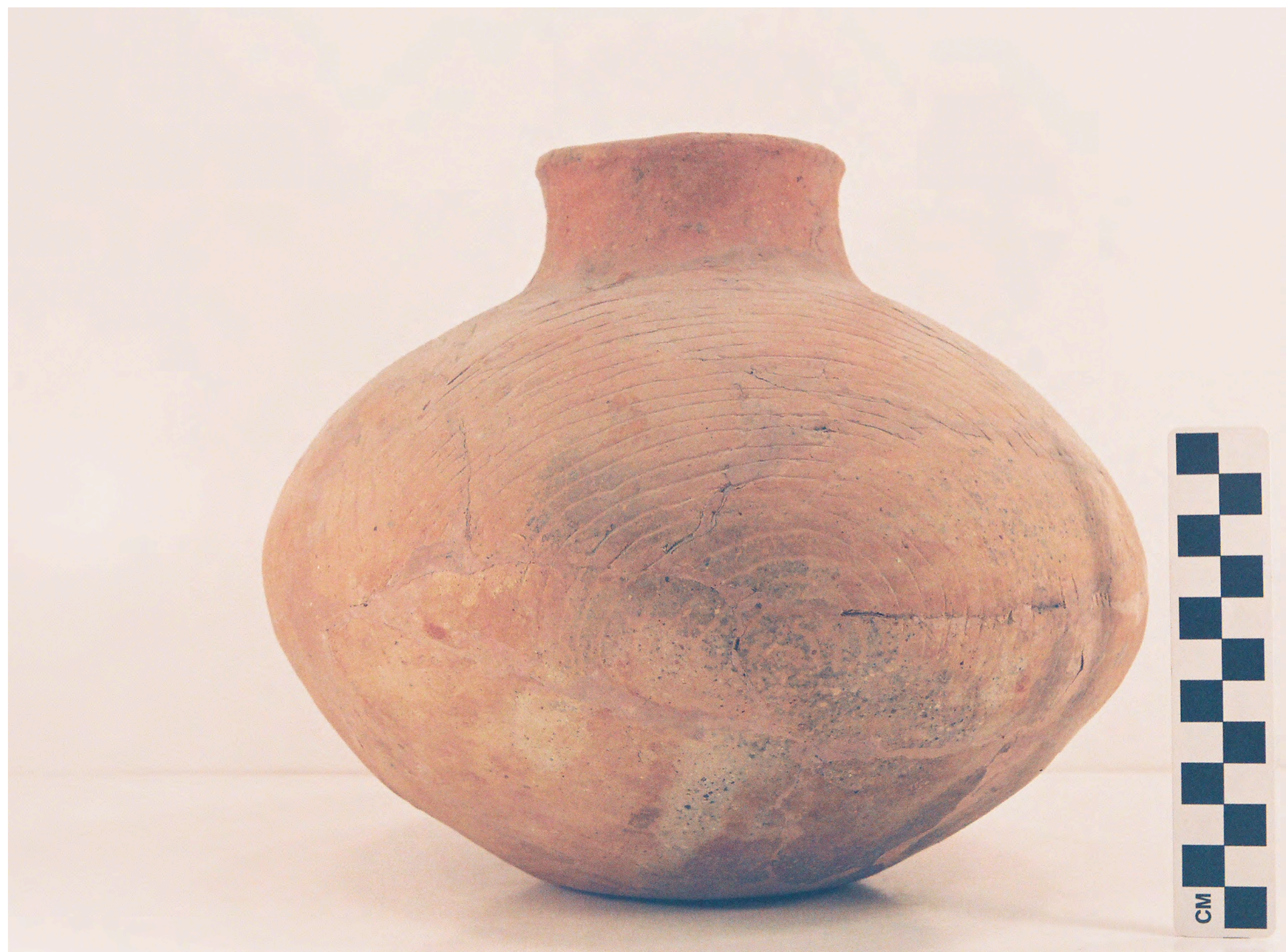

Figure 95 